UNIVERSIDADE DE SÃO PAULO

FACULDADE DE ECONOMIA, ADMINISTRAÇÃO E CONTABILIDADE

DEPARTAMENTO DE ECONOMIA

PROGRAMA DE PÓS-GRADUAÇÃO EM ECONOMIA

Uma Avaliação da Política Pública de Cinema no Brasil no Período 1995-2016

Matheus Rosso

Orientadora: Profa. Dra. Paula Carvalho Pereda

São Paulo

2019 
Prof. Dr. Vahan Agopyan

Reitor da Universidade de São Paulo

Prof. Dr. Fábio Frezatti

Diretor da Faculdade de Economia, Administração e Contabilidade

Prof. Dr. José Carlos de Souza Santos

Chefe do Departamento de Economia

Prof. Dr. Ariaster Baumgratz Chimeli

Coordenador do Programa de Pós-Graduação em Economia 
MATHEUS ROSSO

\section{Uma Avaliação da Política Pública de Cinema no Brasil no Período 1995-2016}

Dissertação apresentada ao Departamento de Economia da Faculdade de Economia, Administração e Contabilidade da Universidade de São Paulo como requisito parcial para a obtenção do título de Mestre em Ciências.

Orientadora: Profa. Dra. Paula Carvalho Pereda

Versão original

São Paulo 
Ficha catalográfica

Elaborada pela Seção de Processamento Técnico do SBD/FEA com os dados inseridos pelo(a) autor(a)

Rosso, Matheus.

Uma Avaliação da Política Pública de Cinema no Brasil no Período 1995 2016 / Matheus Rosso. - São Paulo, 2019. $170 \mathrm{p}$.

Dissertação (Mestrado) - Universidade de São Paulo, 2019. Orientador: Paula Carvalho Pereda.

1. Economia da Cultura. 2. Cinema. 3. Política pública. 4. Avaliação de impacto. I. Universidade de São Paulo. Faculdade de Economia, Administração e Contabilidade. II. Título. 


\section{Agradecimentos}

Agradeço ao CNPq pelo apoio financeiro e à Universidade de São Paulo pela estrutura proporcionada durante o período de mestrado.

Mais do que o apoio e a motivação ao desenvolvimento desta dissertação, registro meus sinceros agradecimentos à professora Paula Carvalho Pereda pelo aprendizado contínuo, o insistente estímulo ao rigor e à dedicação e pelas oportunidades ao longo dos últimos dois anos. Um bom professor sempre ensina mais com atitudes e gestos do que com o aprendizado formal.

Muito do que foi abordado neste trabalho se deve às prestimosas recomendações dos professores Marcos Nakaguma e Rafael Ferreira, aos quais também agradeço pela participação nas diversas oportunidades de avaliação da dissertação.

Agradeço a todos os professores do programa de pós-graduação em Economia da FEA-USP pelo conhecimento compartilhado. Em especial, às professoras Fabiana Rocha e Maria Dolores pelas experiências de estágio docente. Meus agradecimentos pela gentil prestatividade dos funcionários da FEA-USP, em especial ao pessoal da Secretaria de Pós-Graduação, ao Pinho e à Alessandra.

O fardo seria mais pesado sem o apoio, a convivência e os incontáveis bares divididos com os colegas do mestrado. Obrigado, Bernardo Ostrovski, Camila Steffens, Daniel Casula, Ahmad Mourad e Vinícius Reginato pelos momentos compartilhados.

Por fim, agradeço pelo lastro emocional e o apoio financeiro da família e pelo companheirismo, mesmo à distância, dos meus amigos. 



\section{Resumo}

O cinema brasileiro é altamente dependente de incentivos governamentais, tendo em vista a evolução institucional da participação do Estado no setor. Os principais exemplos são a empresa estatal responsável pela produção e distribuição de filmes no país (Embrafilme) e, após sua dissolução, o incentivo fiscal e a criação da Ancine e do Fundo Setorial do Audiovisual. Entre 1995 e 2016, dos 1.370 filmes nacionais exibidos no país, 930 dispuseram de captação de incentivo fiscal, o principal mecanismo de fomento do período, que incentivou um total de $\mathrm{R} \$ 5,7$ bilhões. Considerando a escassez de recursos públicos para a cultura no país (0,3\% do gasto público em 2010), torna-se ainda mais importante avaliar a eficácia da política pública de cinema (cerca de 3\% da despesa pública com cultura em 2010). O principal objetivo declarado da política consiste na ampliação do acesso do consumidor brasileiro a filmes nacionais, o que orientou a definição de uma estratégia empírica apropriada para a avaliação de impacto. Então, a partir de uma base de dados inédita construída, encontrou-se que a Ancine, principal mudança institucional do período analisado, não impactou a proporção de filmes nacionais exibidos no país. Além disso, o modelo de diferenças-em-diferenças indicou que o funcionamento da agência de regulação ampliou a participação esperada de um filme nacional no total anual de público em 0,5 ponto percentual na comparação com filmes internacionais comparáveis, o que representa um acréscimo de público médio de 150.000 pessoas. Através de uma estratégia de estimação por variáveis instrumentais, encontrou-se uma elasticidade da bilheteria dos filmes nacionais com relação ao incentivo fiscal de apenas 0,05. Os resultados encontrados foram corroborados por análises de robustez e extensões desenvolvidas. A pesquisa demonstrou que a política de cinema no Brasil teve impactos econômicos de alcance limitado e que as ineficiências que se deseja corrigir não foram definidas de maneira inequívoca, o que prejudica a avaliação dos programas implementados e, portanto, a própria condução da política pública.

Palavras-chave: Economia da Cultura, cinema, política pública, avaliação de impacto. 



\begin{abstract}
Brazilian motion pictures industry is highly dependent on governmental incentives, as institutional change in state actions over the sector shown. The main examples are the state company producing and distributing movies in the country (Embrafilme) and, after its extinction, fiscal incentives and the creation of Ancine and Audio-visual Sectoral Fund (FSA). Between 1995 and 2016, 930 movies from a total of 1,370 national movies exhibited in Brazil were financed through fiscal incentive mechanisms, where this financial promotion reached R\$5.3 billions. Given the scarcity of resources allocated in culture $(0.3 \%$ of public expenditure in 2010), it is even more relevant to evaluate the efficacy of public policy over cinema (approximately 3\% of public expenditure on culture in 2010). The main declared objective consists on increasing Brazilian consumption of national movies, which guided the definition of a proper empirical strategy to impact evaluation. Then, given the novel database constructed, it was found that Ancine, the main institutional change over the period of analysis, did not affect the share of Brazilian movies exhibited in the country. The difference-in-differences model showed that the regulation agency operations increased the expected share in annual total attendance of Brazilian movies in 0.5 percentage point as compared to the expected share of comparable international movies, which represents an expected increase in attendance of 150,000 people. The instrumental variables estimation strategy presented a low box office elasticity with respect to fiscal incentive, which is equal to 0.05. All results found were confirmed by robustness analysis. The research has shown that cinema policy in Brazil has limited economic impacts and that inefficiencies they want to correct have not been unequivocally defined, which negatively affects implemented programs evaluation and, therefore, public policy management and accountability.
\end{abstract}

Keywords: cultural economics, cinema, public policy, impact evaluation. 



\section{Sumário}

Sumário . . . . . . . . . . . . . . . . . . . . 11

Lista de tabelas $\ldots \ldots \ldots \ldots \ldots$. . . . . . . . . . . . 15

Lista de ilustrações $\ldots \ldots \ldots \ldots$

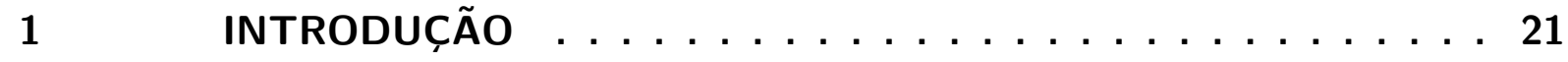

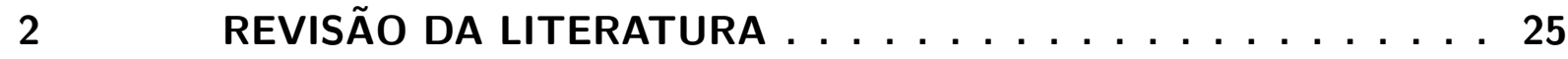

3 DESCRIÇÃO DA POLÍTICA PÚBLICA $\ldots \ldots \ldots \ldots$. . . . . 27

$3.1 \quad$ Histórico da política pública de cinema $\ldots \ldots \ldots$

$3.2 \quad$ A política pública do incentivo fiscal para o audiovisual $\ldots \ldots 29$

$3.3 \quad$ A política pública do incentivo fiscal para o cinema . . . . . . . 31

$3.4 \quad 0$ processo de captação de recursos de incentivo fiscal . . . . . . . 35

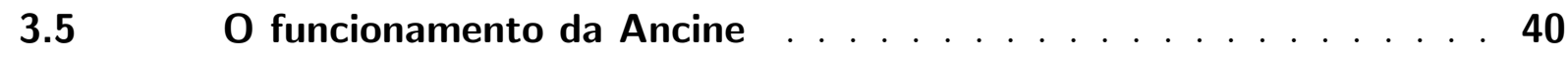

3.5.1 Início das atividades da Ancine e primeiras medidas de regulação e de fomento 44

3.5.2 Evidências de enforcement das medidas de regulação e de fiscalização . . . 47

$3.5 .3 \quad$ Histórico de gestão da Ancine . . . . . . . . . . . . . . . 50

$3.6 \quad 0$ investimento direto através do FSA $\ldots \ldots \ldots \ldots 2$

$3.7 \quad$ Conclusão $\ldots \ldots \ldots \ldots \ldots \ldots$

$4 \quad$ BASES DE DADOS E ESTATIISTICAS DESCRITIVAS . . . . . 61

$4.1 \quad$ Descrição das bases de dados . . . . . . . . . . . 61

$4.2 \quad$ Estatísticas dos filmes exibidos no país entre 2001 e 2016 . . . . . . 63

$4.3 \quad$ Estatísticas dos filmes nacionais exibidos no país $\ldots \ldots \ldots$

$4.4 \quad$ Exemplos de filmes específicos . . . . . . . . . . . . . 85

$4.5 \quad$ Considerações importantes para a metodologia . . . . . . . . . 8 87

5 METODOLOGIA $\ldots \ldots \ldots \ldots$. . . . . . . . 89

$5.1 \quad$ Objetivos da política pública e formas de tratamento . . . . . . 899

5.2 Questões investigadas e modelos econométricos . . . . . . . . . 90 
5.2.1 A Ancine impactou a proporção de filmes nacionais exibidos? . . . . . . . . 91

5.2.2 O funcionamento da Ancine impactou o público de filmes nacionais frente ao de internacionais? . . . . . . . . . . . . . . . . . . . . . . . . . 92

5.2.3 Qual o efeito dos valores incentivados sobre a bilheteria dos filmes nacionais? 95

5.2.4 Qual o efeito dos valores incentivados sobre as receitas relativas dos filmes nacionais? . . . . . . . . . . . . . . . . . . . . . . . 100

5.2.5 Qual o efeito dos valores incentivados sobre a qualidade dos filmes nacionais? 101 $5.3 \quad$ Estímulo ao gênero de documentários . . . . . . . . . . . . . . 102 $5.4 \quad$ Conclusão $\ldots \ldots \ldots$. . . . . . . . . . . . . . . . 104

$6 \quad$ RESULTADOS $\ldots \ldots \ldots \ldots \ldots$

$6.1 \quad$ Ancine e a proporção de filmes nacionais . . . . . . . . . . . . 105

$6.2 \quad$ Ancine e o público de filmes nacionais $\ldots \ldots$. . . . . . . . . . . 107

$6.3 \quad$ Valores incentivados e a bilheteria de filmes nacionais . . . . . . 111

$6.4 \quad$ Valores incentivados e a receita relativa $\ldots \ldots$. . . . . . . . . 117

$6.5 \quad$ Valores incentivados e o rating de filmes nacionais $\ldots . . . . . .118$

$6.6 \quad$ Estímulo ao gênero de documentários . . . . . . . . . . . . . . . 119

7 ROBUSTEZ E EXTENSÕES . . . . . . . . . . . . . . . . . . . . 123

$7.1 \quad$ Modelo 1 $\ldots \ldots$. . . . . . . . . . . . . . . . . . . . . . . . . . 123

7.1.1 Interações entre a variável de tratamento e dummies de gênero . . . . . . . 123

$7.2 \quad$ Modelo 2 $\ldots \ldots \ldots \ldots$

7.2.1 Regressões com tendências grupo-específicas . . . . . . . . . . . . 125

7.2.2 Interações entre a variável de tratamento e dummies de gênero . . . . . . . 126

7.2.3 Filmes internacionais tendo como referência distintas categorias de origem . 128

7.2.4 Aleatorização das definições das variáveis Nacional e Ancine . . . . . . . . 130

$7.3 \quad$ Modelo 3 . . . . . . . . . . . . . . . . . . . . . . . . 132

7.3.1 Interações entre os valores incentivados e dummies de gênero . . . . . . . . 132

7.3.2 Distinção do incentivo fiscal a um filme destinado a cada segmento de atividade . . . . . . . . . . . . . . . . . . . . . . 134

7.3.3 Aleatorização da definição das variáveis instrumentais para o incentivo fiscal 135

7.3.4 Propensity score-matching da bilheteria de filmes com e sem captação . . . 137

7.4 Modelos 4 e 5 . . . . . . . . . . . . . . . . . . 138 
7.4 .1 Interações entre os valores incentivados e dummies de gênero . . . . . . . . 138

$7.5 \quad$ Estímulo ao gênero de documentários . . . . . . . . . . . . . . . 139

7.5.1 Interações entre os valores incentivados e dummies de qualificativo de gênero 139

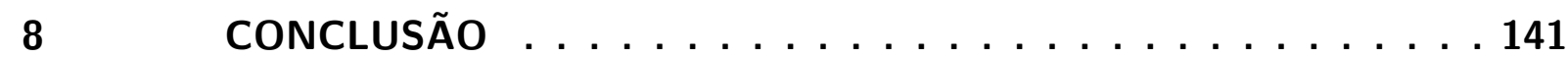

9 ANEXOA $\ldots \ldots \ldots \ldots \ldots \ldots$

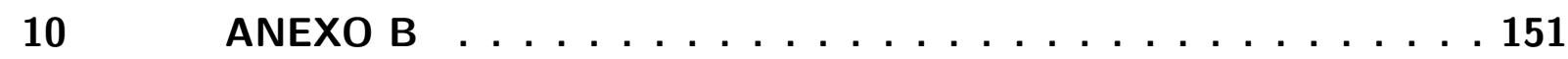

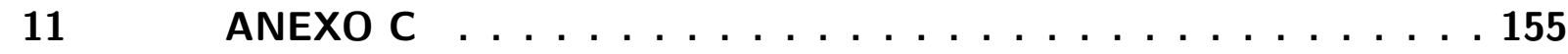

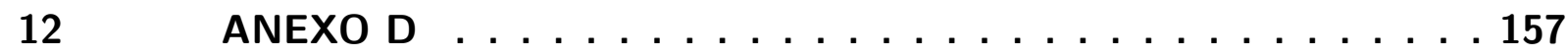

13 APÊNDICE A - DEFINIÇÕES, SIGLAS E ABREVIAÇÕES . . . . . 159

14 APÊNDICE B - DISTRIBUIÇÃO E EXIBIÇÃO . . . . . . . . . . . 165

15 APÊNDICE C - ÍNDICE DE CONVENCIONALIDADE $\ldots 169$ 



\section{Lista de tabelas}

Tabela 3.1 -Pedidos por segmento do audiovisual . . . . . . . . . . . . . . . . . . . 30

Tabela 3.2 -Pedidos por segmento de cinema . . . . . . . . . . . . . . . . . . 32

Tabela 3.3 -Pedidos de cinema por gênero . . . . . . . . . . . . . . . . . . . 33

Tabela 3.4 -Pedidos de cinema por UF . . . . . . . . . . . . . . . . . . . . 33

Tabela 3.5 - Parâmetros do incentivo fiscal sob a Lei do Audiovisual e a Lei Rouanet 35

Tabela 3.6 - Distribuição dos pedidos por CNPJ . . . . . . . . . . . . . . . . . . . 38

Tabela 3.7 -Investimento direto através do FSA . . . . . . . . . . . . . . . . . . . . 55

Tabela 4.1 - Principais variáveis da base de dados consolidada . . . . . . . . . . . . 62

Tabela 4.2 -Diferenças de médias . . . . . . . . . . . . . . . . . . . 65

Tabela 4.3 -Estatísticas de público por origem $\ldots \ldots$. . . . . . . . . . 66

Tabela 4.4 - Estatísticas de público por gênero . . . . . . . . . . . . . . . . . 68

Tabela 4.5 - Estatísticas de público por produtora/distribuidora . . . . . . . . . . . 72

Tabela 4.6 - Estatísticas de público de filmes nacionais por UF . . . . . . . . . . . . 75

Tabela 4.7 - Estatísticas de público de filmes nacionais por gênero, pré e pós-Ancine 76 Tabela 4.8 - Captação de incentivo fiscal por gênero, pré e pós-Ancine (em reais de

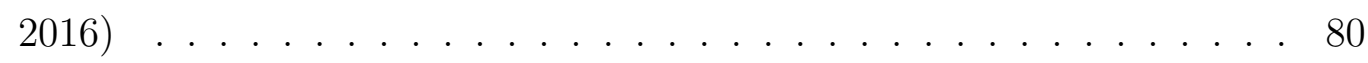

Tabela 4.9 - Valores incentivados através de fontes não fiscais (em reais de 2016) . . 82

Tabela 4.10-Tempo estimado de produção médio (em anos) . . . . . . . . . . . . . 84

Tabela 6.1 - Estimação do modelo que explica a probabilidade de um filme exibido ser nacional . . . . . . . . . . . . . . . . . . . . 106

Tabela 6.2 - Estimação do modelo de diferenças-em-diferenças . . . . . . . . . . . . 108

Tabela 6.3 - Estimação do modelo de diferenças-em-diferenças . . . . . . . . . . . . 109

Tabela 6.4 - Estimação de VI do modelo que explica a bilheteria de filmes nacionais - Primeiro estágio . . . . . . . . . . . . . . . . 115

Tabela 6.5 - Estimação de VI do modelo que explica a bilheteria de filmes nacionais - Segundo estágio . . . . . . . . . . . . . . . . . 116

Tabela 6.6 - Estimação dos modelos que explicam a receita relativa e a avaliação do público dos filmes nacionais . . . . . . . . . . . . . . . . . . . 119 
Tabela 6.7 - Estimação do modelo que explica a avaliação do público dos documentários nacionais . . . . . . . . . . . . . . . . . . . . . . . . 121

Tabela 7.1 - Interações entre a variável de tratamento e dummies de gênero. . . . . . 124

Tabela 7.2 - Estimação do modelo de diferenças-em-diferenças (tendências grupoespecíficas

Tabela 7.3 - Interações entre a variável de tratamento e dummies de gênero. . . . . . 127

Tabela 7.4-Regressões de diferenças-em-diferenças para categorias específicas de origem . . . . . . . . . . . . . . . . . . . . . . 129

Tabela 7.5 - Interações entre os valores incentivados e dummies de gênero - Estimação de VI. . . . . . . . . . . . . . . . . . . . . . . . . . . . . 133

Tabela 7.6 - Distinção do efeito do incentivo fiscal por segmento de atividade de um filme - Estimação de VI . . . . . . . . . . . . . . . . . . . . . . . . . 134

Tabela 7.7 - Interações entre os valores incentivados e dummies de gênero . . . . . . 138

Tabela 7.8 - Interações entre os valores incentivados e dummies de qualificativo de gênero . . . . . . . . . . . . . . . . . . . 140

Tabela 9.1 - Principais incentivadores $\left(\operatorname{artigos} 1^{\circ}, 1^{\circ} \mathrm{A}\right.$ e 18$)$. . . . . . . . . . 147

Tabela 9.2 - Principais incentivadores $\left(\operatorname{artigo} 1^{\circ}\right) \ldots \ldots$. . . . . . . . 147

Tabela 9.3 - Principais incentivadores $\left(\operatorname{artigo} 1^{\circ} \mathrm{A}\right) \ldots \ldots$. . . . . . . . 148

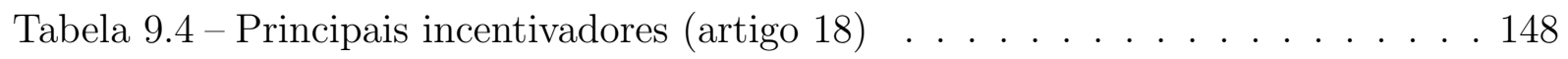

Tabela 9.5 - Principais incentivadores - Por classe de incentivador . . . . . . . . . . 148

Tabela 9.6 - Proporções de adimplência e de inadimplência da Cota de Tela . . . 148

Tabela 9.7 - Inadimplência da cota de tela por tamanho do complexo exibidor (\%)] 149

Tabela 9.8 - Valores arrecadados com multas em virtude do descumprimento da

Cota de Tela $(\mathrm{R} \$)$

Tabela 9.9-Devolução de recursos captados com a Lei do Audiovisual (R\$) . . . . 150

Tabela 9.10-Percentis do retorno do investimento do FSA $\ldots . . . . .150$

Tabela 10.1-Influência de países específicos sobre o público . . . . . . . . . . . . . . 151

Tabela 10.2-Influência de qualificativos de gênero sobre o público . . . . . . . . . . 151

Tabela 10.3-Interação entre origens e gêneros e seu impacto sobre o público . . . 152

Tabela 10.4-Regressões da renda de bilheteria contra o índice de convencionalidade 152

Tabela 10.5-Estatísticas de público de filmes nacionais por gênero . . . . . . . . . . 153 
Tabela 10.6-Estatísticas de público e de valor captado por quantidade de filmes produzidos pelo diretor . . . . . . . . . . . . . . . . . . . . . . 154

Tabela 10.7-Estatísticas de público e de valor captado por quantidade de filmes produzidos previamente pelo diretor . . . . . . . . . . . . . . . . . 154

Tabela 11.1-Estatísticas dos instrumentos . . . . . . . . . . . . . . . . . . 155

Tabela 11.2-Estimação de VI do modelo que explica a bilheteria de filmes nacionais - Segundo estágio (demais mecanismos) . . . . . . . . . . . . . . . 156

Tabela 11.3-Estimação do modelo que explica a probabilidade de um filme nacional ser um documentário . . . . . . . . . . . . . . . . . . . . . 156

Tabela 12.1-Regressões de diferenças-em-diferenças por categoria de origem . . . 157

Tabela 12.2-Estimação por propensity score-matching comparando a bilheteria de projetos incentivados com a de não incentivados . . . . . . . . . . . . . 158

Tabela 14.1-Médias anuais de lançamentos por tipo de distribuidora e por número de salas $(2009-2016)] \ldots \ldots$. . . . . . . . . . . . . 166

Tabela 14.2-Médias anuais do número de salas de exibição por região do Brasil

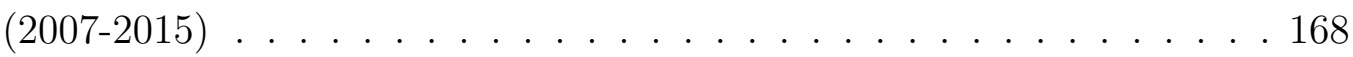

Tabela 14.3-Médias anuais da proporção de municípios com cinema e da proporção do total de salas . . . . . . . . . . . . . . . . . . . . . . . 168

Tabela 15.1-Pontuação do índice de convencionalidade . . . . . . . . . . . . . . 170 



\section{Lista de ilustrações}

Figura 3.1 - Pedidos por ano e proporção de pedidos com captação correspondentes ao cinema . . . . . . . . . . . . . . . . . . 31

Figura 3.2 - Total captado por ano (em milhões de reais de 2016) . . . . . . . . . . 34

Figura 3.3-Fluxograma do pedido de incentivo fiscal . . . . . . . . . . . . . . . . 37

Figura 3.4 - Número de pedidos e valor captado médio por CNPJ . . . . . . . . . . 39

Figura 3.5 - Fluxograma do investimento do Fundo Setorial do Audiovisual . . . . . 53

Figura 3.6 - Organograma da política pública de cinema . . . . . . . . . . . . . . . 59

Figura 4.1 -Filmes exibidos por and . . . . . . . . . . . . . . . . . 64

Figura 4.2 - Público médio (milhares de pessoas) e proporção nacional do público total por ano ........................... 64

Figura 4.3 -Proporções de filmes por origem . . . . . . . . . . . . . . . . . 67

Figura 4.4-Público médio e índice de convencionalidade médio por origem . . . . . 71

Figura 4.5 - Distribuição das avaliações do público dadas por usuários do IMDb . . 73

Figura 4.6 - Filmes nacionais incentivados via renúncia fiscal e proporção do total exibido por ano . . . . . . . . . . . . . . . . . . . 78

Figura 4.7 - Razão média entre o valor captado com incentivo fiscal e a renda de bilheteria por ano . . . . . . . . . . . . . . . . 79

Figura 4.8 - Bilheteria contra o valor captado com incentivo fiscal . . . . . . . . . . 82

Figura 6.1 - Efeitos parciais médios do período de funcionamento da Ancine sobre a probabilidade de um filme exibido ser nacional . . . . . . . . . . . . 107

Figura 6.2 - Parâmetros de tratamento anuais para o modelo do share de público . 110

Figura 6.3 - Parâmetros de tratamento anuais para o modelo de $\ln ($ Publico $)$. . . . 111

Figura 7.1 - Distribuição dos parâmetros de tratamento estimados a partir da aleatorização das variáveis Nacional e Ancine - Amostra completa . . . . 132

Figura 7.2 - Distribuição dos parâmetros de elasticidade estimados a partir da aleatorização do peso de cada mecanismo no total captado por um filme . 136

Figura 9.1 - Mínimo de dias e de títulos distintos por número de salas (2016 e 2017) 149

Figura 10.1-Valor captado com incentivo fiscal médio por ano (em milhões de reais de 2016) . . . . . . . . . . . . . . . . . . 153 
Figura 11.1-Lucro líquido e receita de incentivadoras estatais _ . . . . . . . . . 155

Figura 12.1-Distribuição dos parâmetros de tratamento estimados a partir da aleatorização das variáveis Nacional e Ancine - Observações abaixo dos percentis de $99 \%$ e de $90 \%$. . . . . . . . . . . . . . . . . 158

Figura 14.1-Salas de exibição por ano . . . . . . . . . . . . . . . . 167 


\section{Introdução}

A cultura reúne as diversas possíveis representações artísticas dos valores e dos costumes de um povo e, mais do que isso, em economias de mercado, constitui um setor adicional de geração de renda. Como diversos trabalhos teóricos demonstram, contudo, os mercados de cultura tendem a apresentar falhas de mercado (AUBERT ET AL, 2003), tais como a provisão insuficiente por conta de externalidades positivas e a ocorrência de free rider no consumo de bens não excludentes. Assim, por conta das esperadas intervenções estatais, a política pública sobre cultura representa uma promissora área de pesquisa aplicada.

Nas duas últimas décadas da indústria cinematográfica brasileira, a maturação de formas tradicionais de incentivo, a diversificação dos instrumentos de fomento e a constituição de uma profunda regulação e fiscalização do setor implicam na oportunidade de uma avaliação de políticas públicas em um setor de pouca atenção recebida pelos estudos empíricos em Economia.

O objetivo principal da pesquisa, portanto, reside em avaliar a recente política pública de cinema no Brasil, logo, deseja-se investigar a eficácia da política em concretizar as suas intenções. Com isso, é preciso estabelecer quais são essas intenções e os instrumentos de intervenção disponíveis, com o que se define um objetivo subsidiário de análise da política pública de cinema. Consiste em um objetivo secundário também a descrição da indústria e do mercado brasileiros de cinema.

Políticas públicas buscam a correção de falhas de mercado e, no setor de cinema brasileiro, possíveis falhas a serem apontadas consistem na produção insuficiente de filmes cuja exibição implica em externalidades positivas. Os benefícios da exibição desses filmes extrapolariam o que é captado pela sua bilheteria, uma vez que seu teor instrutivo e reflexivo beneficiaria a formação educacional da população. A compreensão dos valores e dos problemas pertinentes ao país também poderia imprimir um valor social superior ao que é precificado para os filmes nacionais, os quais tendem a ser preteridos frente a produções internacionais. Esse argumento pode ser identificado como o lastro do incentivo à produção e exibição de filmes nacionais.

A análise da política pública, com efeito, definiu a ampliação do acesso do consumidor brasileiro a filmes nacionais como o principal objetivo declarado da política, consistindo 
a expansão da competitividade e da sustentabilidade da indústria de cinema nacional em um objetivo secundário e que se volta à garantia de um maior acesso a obras brasileiras. A eficácia da política em alcançar o seu objetivo declarado principal é mensurada, neste trabalho, através de variáveis de resultado como a distinção da origem de um filme entre nacional e internacional, além de medidas pertinentes à escolha do consumidor, como o público e a bilheteria de cada filme.

Ainda que não haja uma diferenciação de objetivo declarada entre filmes comerciais e aqueles cujo conteúdo tem uma motivação essencial artística ou documental, a prática da política pública manifestou uma intenção de promover o gênero de documentários. Com efeito, a legislação, de um modo geral, não é clara a respeito das ineficiências que a política pública anseia corrigir.

A intervenção do poder público sobre o setor de cinema no Brasil fez uso, nas últimas décadas, dos seguintes instrumentos de política: regulação, fiscalização e fomento. A regulação visa conduzir o funcionamento do setor de modo a que o desempenho dos filmes nacionais seja beneficiado na comparação com seus concorrentes internacionais. A fiscalização, por sua vez, objetiva garantir que os agentes econômicos, ao agir conforme os seus próprios interesses, atenham-se às normas regulatórias e às demais disposições legais. Finalmente, o fomento visa compor o financiamento dos diversos segmentos de atividade. Os principais mecanismos de fomento disponíveis consistem no incentivo fiscal e nos investimentos do Fundo Setorial do Audiovisual.

A abordagem metodológica que busca cumprir o objetivo principal da pesquisa, de avaliação da política pública, parte da definição de cinco questões investigadas: houve impacto da criação e do funcionamento da Ancine sobre a exibição de filmes nacionais? O funcionamento da agência impactou o público de filmes nacionais, comparativamente ao de filmes internacionais? Qual o efeito dos valores incentivados pela política de fomento sobre: a bilheteria, as receitas relativas e a qualidade dos filmes nacionais? Do objetivo secundário de analisar a política pública de cinema, encontrou-se que essa manifestou a intenção de promover o gênero de documentários. Também foram avaliados, portanto, os efeitos da política pública sobre variáveis de resultado específicas para documentários.

Os resultados encontrados demonstram que a Ancine não impactou a proporção de filmes nacionais exibidos no país, ao mesmo tempo que ampliou a participação esperada de um filme nacional no total de público anual na comparação com os filmes internacionais 
(aumento de 0,5 ponto percentual). A política de fomento, sob a forma do incentivo fiscal, teve um impacto positivo, estatisticamente significativo e de pequena magnitude sobre a bilheteria dos filmes nacionais (elasticidade de 0,05). O incentivo fiscal também afetou positiva e significativamente o preço médio do ingresso dos filmes nacionais (aumento de 0,4 p.p., dado aumento de captação de $\mathrm{R} \$ 1$ milhão), enquanto que o investimento do FSA impactou a sua qualidade (aumento de 2,8 p.p., dado aumento de captação de $\mathrm{R} \$$ 1 milhão). Quanto ao gênero de documentários, a Ancine auxiliou na expansão da proporção de documentários nacionais exibidos (aumento de 30 p.p.), ao mesmo tempo em que o investimento do FSA afetou destacadamente a sua qualidade (aumento de 12 p.p., dado aumento de captação de $\mathrm{R} \$ 1$ milhão). Exercícios de robustez foram aplicados a todas as estratégias empíricas, explorando a heterogeneidade dos resultados encontrados e verificando, sempre que possível, a validade das hipóteses de identificação.

O presente trabalho de avaliação da política de cinema no Brasil demandou a superação do problema de obtenção dos dados adequados para as estratégias empíricas implementadas. Encontram-se poucos trabalhos empíricos voltados ao setor de cultura, o que em parte pode ser justificado pela dificuldade de se encontrar dados desagregados, decorrente sobretudo da natureza não mercantil e desconcentrada de grande parte dessas atividades. Já a indústria cinematográfica dispõe, de um modo geral, de um amplo conjunto de dados, dada a escala de seus negócios. A UNESCO, por exemplo, dedica-se a estimular a geração e a difusão de dados para mercados nacionais de cinema.

O Brasil, em particular, por meio do Observatório do Cinema e do Audiovisual (OCA), órgão público vinculado à Agência Nacional do Cinema (Ancine), tem ampla disponibilidade de dados concernentes aos filmes produzidos e exibidos no país. O horizonte temporal dos dados disponíveis, décadas de 1990 até a de 2010, abrange um período importante de mudanças institucionais na condução da política pública do setor, cuja avaliação de impacto consiste justamente no objetivo principal deste trabalho.

O pouco espaço ocupado, na pesquisa aplicada, pelos setores cultural e do audiovisual encontra consonância com a pequena participação da cultura na despesa pública, que alcançou, em 2010, 0,3\% do total gasto (IBGE, 2013). A fins de comparação, a proporção para a União Europeia alcança 1\%, conforme dados da Eurostat. O orçamento das famílias brasileiras igualmente reflete um peso menor atribuído à cultura no país, uma vez que os $\mathrm{R} \$ 106,32$ gastos mensalmente, em média, no ano de 2010, correspondem a 
apenas 5\% do total de despesa familiar (IBGE, 2013). Quanto ao cinema, em particular, esses números se reduzem ainda mais: apenas 1,3\% dos gastos familiares com cultura se destinam a esse consumo.

A ilustração do impacto econômico da indústria do audiovisual encontra dificuldades por conta da extensa informalidade do emprego que abrange o setor (VALIATI; FIALHO, 2017). Ainda assim, de acordo com dados levantados pela Associação Brasileira da Produção de Obras Audiovisuais (APRO), em 2014, o valor adicionado à economia brasileira pelo audiovisual foi de $\mathrm{R} \$ 20,8$ bilhões em 2014, constituindo 0,44\% do PIB nacional do ano. Quanto à arrecadação de impostos, entre tributação direta e indireta, o setor audiovisual arrecadou R \$ 3,4 bilhões em 2014 (APRO, 2016).

Uma primeira contribuição deste trabalho, portanto, decorre da produção de um trabalho empírico em Economia para um setor pouco pesquisado pela Econometria Aplicada, o que requereu a construção de uma base de dados inédita proveniente de diversas fontes. Os resultados da pesquisa, além disso, resultam em uma contribuição para a política pública, dada a avaliação metodológica de uma importante política cultural nacional. Por fim, há uma contribuição informativa, dada pela descrição da evolução e dos parâmetros da atual política pública de cinema, além da representação do perfil da demanda brasileira por cinema e da estrutura da indústria nacional.

Na sequência, o capítulo 2 faz uma breve revisão da literatura de Economia da Cultura e de trabalhos voltados ao setor de cinema. O capítulo 3 descreve a política pública de cinema, enquanto que o capítulo 4 apresenta as bases de dados e as estatísticas descritivas. No capítulo 5, encontra-se a metodologia de investigação das questões definidas pelo objetivo principal. O capítulo 6 traz os resultados da combinação da metodologia proposta com as bases de dados utilizadas, sendo que o capítulo 7 apresenta extensões e análises de robustez. Por fim, o capítulo 8 encerra o trabalho com as principais conclusões.

Tabelas e gráficos cujas informações foram utilizadas ao longo do trabalho estão localizadas em anexos. Constam no apêndice A as definições, siglas e abreviações de aplicação corrente ao longo do trabalho, voltado para a consulta do significado empregado a termos relevantes. O apêndice B, por sua vez, apresenta dados e informações a respeito dos segmentos de atividade da distribuição e da exibição cinematográficas, as quais extrapolam o escopo de investigação empírica do trabalho. 


\section{Revisão da literatura}

Uma primeira fonte de referência para o estudo de uma atividade cultural consiste na Economia da Cultura em sua vertente teórica e expositiva. Chisholm (2011) descreve que a produção de cinema se desdobra em três atividades principais: produção, distribuição e exibição. A produção envolve a preparação do filme, a formação do cast, o processo de filmagem e a edição final. A distribuição inicia com a compra dos direitos do filme produzido por uma distribuidora, responsável por comercializar a obra para diferentes formas de exibição, sendo a exibição em cinemas a principal delas.

Utilizando de dados provenientes de diferentes países, a literatura internacional produziu algumas pesquisas aplicadas de destaque tendo por objeto o mercado de cinema (SISTO E ZANOLA, 2004; SISTO E ZANOLA, 2005; CHISHOLM ET AL, 2006; COLLINS ET AL, 2009; AGOSTINI E SAAVEDRA, 2011). No Brasil, predominam trabalhos descritivos e argumentativos, limitando-se, de um modo geral, à exposição de dados agregados do setor. A limitada produção de artigos de avaliação de impacto utilizando métodos empíricos adequados justifica-se, ao menos parcialmente, em virtude da exiguidade de microdados do setor de cinema no país.

Michel e Avelar (2014) analisam o grau de concentração da indústria cinematográfica brasileira e a inter-relação entre os três segmentos da cadeia produtiva. Segundo os autores, haveria alta concentração na produção em decorrência da pouca disseminação do consumo de filmes nacionais - a cada ano, no máximo três produções se mostram bem sucedidas. Com relação aos setores distribuidor e exibidor, esses privilegiam filmes estrangeiros, os quais apresentam uma rentabilidade esperada superior. Os autores concluem, assim, que a política pública deveria atuar simultaneamente nos três elos da indústria, de modo a ampliar a eficiência da intervenção realizada, que atualmente focaliza o segmento da produção.

Fornazari (2006) analisa o quadro político e institucional da criação e da atuação da Ancine. A principal contribuição do autor consiste na comparação da política pública sobre cinema no Brasil com outras experiências internacionais. Elencando os casos da Argentina, do México, da França e do Reino Unido, percebe-se uma atuação mais autônoma e com um número maior de incumbências por parte da agência brasileira. 
Fica ilustrada a predominância de trabalhos descritivos e expositivos, que, a despeito de sua importância informativa, são incapazes de produzir uma rigorosa avaliação de políticas públicas, objeto de investigação fundamental nesse setor de tamanha dependência do setor público. Uma proposta inovadora em analisar a política pública de cinema no Brasil através de uma metodologia rigorosa é dada por Wink Júnior e Mattos (2011), que em seu artigo objetivam investigar se a criação da Ancine e as leis de incentivo ao cinema contribuíram para a evolução, no período 1995-2008, da renda de bilheteria dos filmes nacionais e da participação de seu público no público total.

A metodologia do seu trabalho consistiu na estimação por SUR (seemingly unrelated regression) de um sistema de equações para as variáveis dependentes renda de bilheteria e participação de público dos filmes no total de público. As variáveis explicativas, em ambas as equações, foram: o preço médio do ingresso do filme (razão renda de bilheteria/público), uma dummy indicando se tratar o filme de uma produção carioca ou não, duas dummies para o gênero do filme (ficção ou documentário, com a referência consistindo em animação), o valor captado pelo filme com incentivos fiscais, o número de salas no país por ano e, por fim, uma dummy indicando se o filme foi exibido após a criação da Ancine.

Dentre os principais resultados das estimações, os autores encontraram evidências de efeito do valor captado sobre a renda e o público dos filmes nacionais. Igualmente, a dummy para a Ancine se mostrou significativa na equação da renda de bilheteria dos filmes, o mesmo não valendo para o share no total de público. Segundo Wink Júnior e Mattos (2011), isso pode se dever ao aumento no número de produções, o que reduz a proporção de público de uma produção individual.

O objetivo do presente trabalho é somar-se a esses esforços incipientes de aplicação de métodos empíricos à análise de políticas culturais no Brasil. Em comparação ao trabalho anteriormente citado, deseja-se, além de se propor um conjunto alternativo de ferramentas econométricas, expandir a base de dados considerada, ao se contemplar filmes internacionais e algumas variáveis adicionais. 


\section{Descrição da política pública}

A identificação dos efeitos de alterações na política pública sobre o desempenho do cinema nacional requer uma adequada compreensão de como a política evoluiu e de como se estrutura atualmente. Para tanto, em um primeiro momento serão descritos o histórico da política no país e, então, o atual quadro institucional, para que, na sequência, a exposição de dados reforce o entendimento de como se efetivou o incentivo fiscal ao cinema no país nas últimas décadas. Também serão enunciados alguns detalhes do processo de captação de recursos, de modo que se compreendam a formação do valor captado por um projeto e as motivações e incentivos tanto de provedores quanto de captadores. Ao fim do capítulo, seguem descrições de outras duas dimensões da política pública de cinema: a regulação e a fiscalização por parte da Ancine e o investimento direto através do FSA.

\subsection{Histórico da política pública de cinema}

A atuação do Estado junto ao setor de cinema no país inicia em 1969, ano de criação da estatal Embrafilme, a qual consistiu em uma empresa pública produtora e distribuidora de filmes. De 1969 a 1990, a política pública de cinema foi marcada pela provisão direta de bens pelo poder público, o que implica em uma considerável discricionariedade no apoio dado a projetos.

Com a mudança de concepção do que seria de incumbência do Estado, a partir da eleição de Collor, a Embrafilme é extinta, passando ao centro da política cultural o incentivo fiscal. Assim, em 1991 fica instituída a Lei Rouanet, que criava novas diretrizes para o apoio ao setor cultural, fundamentalmente através do instrumento da renúncia fiscal. Em 1993, a Lei do Audiovisual particularizou o incentivo fiscal para o setor de cinema e demais atividades audiovisuais.

O fim da década de 1990 e o início dos anos 2000 foram marcados por um conjunto de reformas regulatórias. Dentre diversas agências criadas pelo governo FHC, destaca-se a Agência Nacional do Cinema (Ancine), instituída em 2001. Tal medida objetivou centralizar tanto a regulação quanto o fomento das atividades cinematográficas.

O último movimento da política pública de cinema no país consistiu na diversificação 
do apoio público através do investimento direto, com a criação, em 2006, do Fundo Setorial do Audiovisual (FSA). Dessa forma, a atual política pública de cinema no país contempla a regulação, o incentivo fiscal e o investimento direto.

É oportuna, agora, uma descrição das leis e programas que compõem a atual política pública de cinema. A Lei 8.313 (BRASIL, 1991), difundida sob a denominação de Lei Rouanet, estabeleceu o Programa Nacional de Apoio à Cultura (Pronac), com os objetivos principais de estímulo ao consumo de cultura e à produção nacional de valores artísticos e culturais. Enquanto instrumentos principais de fomento, elencam-se a criação do Fundo Nacional da Cultura (FNC) e a promoção de incentivos fiscais destinados a projetos culturais. A Lei Rouanet é marcada pela generalidade tanto de seus objetivos quanto com relação aos destinos do apoio que prescreve. Portanto, trata-se de um ponto de partida da política cultural que vigoraria nas décadas seguintes.

Com a Lei 8.685 (BRASIL, 1993), reconhecida como a Lei do Audiovisual, instituíram-se instrumentos próprios de incentivo aos setores produtor, distribuidor e exibidor de conteúdo audiovisual. Consistindo em incentivos fiscais, a lei define os critérios para a obtenção de recursos por projetos, os limites para a dedução fiscal, além de normas de ordem tributária. Ficou institucionalizada, então, a política pública de incentivo fiscal sobre o setor audiovisual, particularizando o que fora previsto pela Lei Rouanet.

São quatro os artigos principais da Lei do Audiovisual, que pormenorizam os instrumentos de incentivo fiscal criados com a lei. O artigo $1^{\circ}$ define o abatimento de IR a quem invista em projetos cinematográficos nacionais independentes, isto é, deve-se comprovar a compra de cotas de participação em projetos, enquanto que o artigo $1^{\circ}$-A define o abatimento de IR em contrapartida a patrocínios. O artigo $3^{\circ}$ estabelece, também em contrapartida ao investimento em projetos nacionais independentes, a renúncia fiscal de impostos devidos por empresas distribuidoras e exibidoras ao explorarem domesticamente conteúdos de propriedade estrangeira. Já o artigo $3^{\circ}$-A implica em renúncia fiscal de impostos devidos em decorrência da exploração de conteúdo estrangeiro na TV.

A Medida Provisória 2.228-1 (BRASIL, 2001), em seu artigo 5º, criou a Agência Nacional do Cinema (Ancine), com atribuições de regulação, fiscalização e fomento. Com os objetivos principais de promover a cultura nacional, aumentar a competitividade da indústria cinematográfica nacional e aprofundar o acesso às obras cinematográficas, especialmente as nacionais, a Ancine concentrou a regulação, a fiscalização e a promoção dos 
instrumentos de fomento às atividades audiovisuais. Após a sua constituição, todos os projetos audiovisuais que se propõem a contar com o apoio de recursos públicos devem ser avalizados pela agência.

O Fundo Setorial do Audiovisual (FSA) foi criado em 2006 e passou a operar em 2008, destinando recursos públicos a investimentos em projetos de audiovisual, tanto os de natureza cinematográfica quanto os de natureza televisiva. O FSA opera com base em três programas instituídos pelo artigo $47^{\circ}$ da MP 2.228-1: o Programa de Apoio ao Desenvolvimento do Cinema Brasileiro (Prodecine), o Programa de Apoio ao Desenvolvimento do Audiovisual Brasileiro (Prodav) e o Programa de Apoio ao Desenvolvimento da Infra-Estrutura do Cinema e do Audiovisual (Pró-Infra).

O fomento protagonizado pelo FSA envolve chamadas públicas dos programas Prodecine, voltado a projetos cinematográficos, Prodav, destinado a projetos televisivos, e Programa Cinema Perto de Você (PCPV), forma acabada do Pró-Infra. Após apresentado um projeto à Ancine, essa define se atende à demanda por recursos e em que proporção. Liberados os recursos, o FSA atua como investidor, tendo participação na rentabilidade do projeto quando esse é maturado.

Discutidos a evolução e o quadro institucionais da política pública de cinema do país, percebe-se que essa diversificou-se progressivamente do incentivo fiscal para a regulação e a fiscalização e, por fim, para o investimento direto. Dessa forma, sobretudo por conta do último mecanismo citado, ampliou-se o grau esperado de participação do setor público no direcionamento do setor.

\subsection{A política pública do incentivo fiscal para o audiovisual}

As autoridades responsáveis pela gestão da política pública do audiovisual (Ministério da Cultura e, posteriormente, a Ancine) receberam, entre 1992 e 2017, 12.887 pedidos de incentivo fiscal, dentre os quais 3.734 (29\%) tiveram captação positiva no períodd 1 , culminando em uma captação de $\mathrm{R} \$ 6,9$ bilhões (a preços de 2016). Os segmentos de atividade que são definidos como sendo de audiovisual totalizam 21 diferentes categorias, as quais são listadas na tabela 3.1 abaixo.

O predomínio de pedidos associados aos segmentos de cinema é notório, sobretudo

1 Fonte: dados do registro de pedidos de incentivo fiscal obtido da Ancine após requerimento junto à Lei do Acesso à Informação 
quando considerados os pedidos de produção cinematográfica, que perfazem mais da metade dos pedidos. Curiosamente, a proporção de pedidos contemplados que corresponde a produções cinematográficas é superior, entre 1992 e 2017, à proporção total de pedidos desse segmento (60\% contra $52 \%$ ), de modo que se pode esperar ao menos um dos seguintes fatos: os pedidos de produção cinematográfica são melhores, especialmente em termos de viabilidade financeira, ou há uma predileção por esse segmento por parte dos gestores da política pública.

Tabela 3.1 - Pedidos por segmento do audiovisual

\begin{tabular}{lcc|lcc}
\hline \multicolumn{1}{c}{ Segmento } & Pedidos & Total Capt $>\mathbf{0}$ & Segmento & Pedidos & Total Capt >0 \\
\hline Produção Cinematográfica & $6.697(52,0 \%)$ & $2.257(60,4 \%)$ & Videofonográfica & $139(1,1 \%)$ & $25(0,7 \%)$ \\
Salas de Exibição & $1.222(9,5 \%)$ & $123(3,3 \%)$ & Multimídia & $24(0,2 \%)$ & $0(0,0 \%)$ \\
Produção Televisiva & $1.076(8,4 \%)$ & $320(8,6 \%)$ & Rádio/Tvs Educativas & $10(0,1 \%)$ & $3(0,1 \%)$ \\
Eventos & $1.068(8,3 \%)$ & $44(1,2 \%)$ & Vídeo Doméstico & $10(0,1 \%)$ & $1(0,0 \%)$ \\
TV Paga & $917(7,1 \%)$ & $268(7,2 \%)$ & Aquisição de ações & $9(0,1 \%)$ & $8(0,2 \%)$ \\
Exibição Cinematográfica & $518(4,0 \%)$ & $251(6,7 \%)$ & Música em Geral & $3(0,0 \%)$ & $0(0,0 \%)$ \\
Distribuição Cinematográfica & $366(2,8 \%)$ & $190(5,1 \%)$ & Dança & $2(0,0 \%)$ & $0(0,0 \%)$ \\
Difusão & $276(2,1 \%)$ & $9(0,2 \%)$ & Preserv. da Memória & $2(0,0 \%)$ & $1(0,0 \%)$ \\
TV Aberta & $212(1,7 \%)$ & $53(1,4 \%)$ & Artes Integradas & $1(0,0 \%)$ & $0(0,0 \%)$ \\
Infra. Técnica Audiovisual & $176(1,4 \%)$ & $65(1,7 \%)$ & Artesanato/Folclore & $1(0,0 \%)$ & $0(0,0 \%)$ \\
Desenvolvimento de projeto & $158(1,2 \%)$ & $116(3,1 \%)$ & Total & 12.887 & 3.734 \\
\hline
\end{tabular}

Fonte: Ancine. Elaboração própria.

Embora os pedidos de segmentos de cinema (produção cinematográfica, salas de exibição, exibição cinematográfica e distribuição cinematográfica) correspondam a 68\% do total, o padrão de busca por incentivo fiscal parece estar se modificando desde o início da década de 2010. A figura 3.1(a) indica a evolução do total de pedidos entre 1992 e 2017, havendo distinção entre os segmentos de cinema e de não cinema. Até por volta de 2010, os pedidos para projetos não vinculados diretamente ao cinema cresciam em linha ou abaixo do total de pedidos. A partir daquele ano, porém, cresceu fortemente a proporção de pedidos exceto cinema (de 15\% em 2010 para um mínimo de 32\% em 2016) 2 , Quanto à captação de recursos, a figura 3.1(b) sugere um comportamento análogo, conforme diminui também, a partir de 2012, a proporção dos pedidos contemplados que se volta para os segmentos de cinema ${ }^{3}$. Uma última evidência da mudança de foco da política do audiovisual parte do mecanismo principal de captação de recursos por ano. Considerando

2 Em particular, os primeiros pedidos para TV aberta e para TV paga remontam a 2010, ano no qual os dois segmentos apresentaram apenas 2 pedidos cada. Em 2013, a TV aberta seria responsável por 27 pedidos e a TV paga por 109.

3 Adicionalmente, também cai no tempo a proporção do total de pedidos de cinema que tem captação positiva. 
os instrumentos de incentivo fiscal disponíveis e citados na seção anterior, entre 1992 e 2004 o artigo 1o (correspondente a investimentos, sobretudo de cinema) foi predominante, enquanto que no período de 2005 a 2013 o artigo 1oA (correspondente a patrocínios, sobretudo de cinema) teve o maior volume de recursos incentivados, culminando no artigo 3oA (investimento de TV) como sendo o principal mecanismo entre 2014 e 2017.

Figura 3.1 - Pedidos por ano e proporção de pedidos com captação correspondentes ao cinema
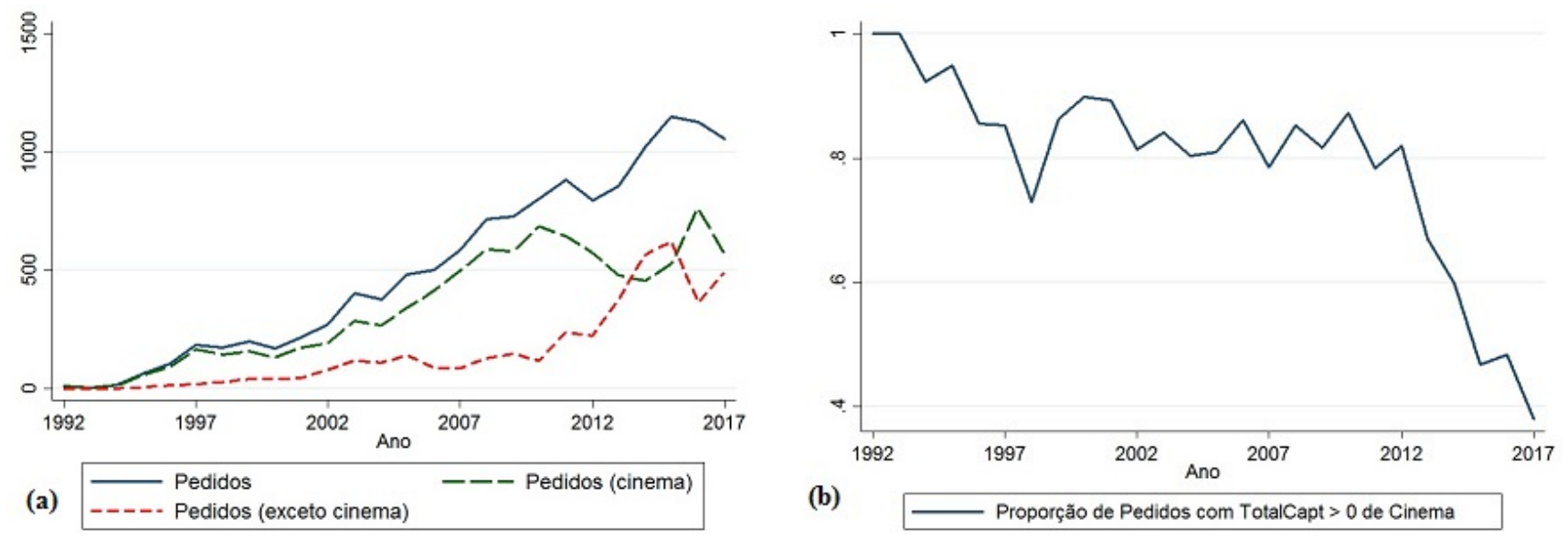

(b)

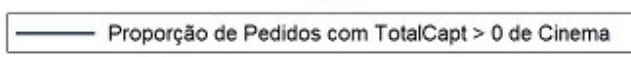

Fonte: Ancine. Elaboração própria.

Portanto, a política do audiovisual se voltou predominantemente ao setor de cinema no decorrer das últimas décadas, confirmando, assim, ter sido esse o foco durante as transformações institucionais realizadas. Ainda assim, o cenário para os próximos anos aponta para um maior volume de incentivos fiscais para produções de TV, o que sugere um esgotamento da política voltada ao cinema.

\subsection{A política pública do incentivo fiscal para o cinema}

Utilizando a classificação das atividades de audiovisual presente na relação de projetos cedida pela Ancine, define-se o setor de cinema a partir das quatro categorias a seguir: produção cinematográfica, sala de exibição, exibição cinematográfica e distribuição cinematográfica. Então, encontram-se, entre 1992 e 2017, 8.803 pedidos de incentivo, havendo captação positiva para 2.821 deles $(32 \%)$, proporção um pouco superior ao verificado para os pedidos como um todo, novamente tornando factível que a política pública do audiovisual priorize o setor de cinema. Além disso, a totalidade dos pedidos de cinema 
contemplados resultou na captação de $\mathrm{R} \$ 5,7$ bilhões (a preços de 2016), o que representa $82 \%$ do total captado com incentivo fiscal pelo setor do audiovisual.

A análise da tabela 3.2 abaixo demonstra que também dentro do setor de cinema a produção cinematográfica tem predomínio, tanto com relação aos pedidos $(76 \%$ do total de pedidos) quanto em termos de pedidos atendidos ( $80 \%$ do total atendido). A pequena proporção de pedidos de distribuição cinematográfica se mostra coerente com a constatação de que a atividade de distribuição se restringe a grandes produções, as quais têm maior facilidade de captação de recursos de origem privada, enquanto que as produções de menor porte tendem a produzir e a encontrar canais de comercialização a partir do próprio budget de produção. Por fim, novamente chama a atenção a proporção significativamente menor do que a esperada de pedidos atendidos do segmento de salas de exibição.

Tabela 3.2 - Pedidos por segmento de cinema

\begin{tabular}{lcc}
\hline \multicolumn{1}{c}{ Segmento } & Pedidos & Total Capt >0 \\
\hline Produção Cinematográfica & $6.697(76,1 \%)$ & $2.257(80,0 \%)$ \\
Salas de Exibição & $1.222(13,9 \%)$ & $123(4,4 \%)$ \\
Exibição Cinematográfica & $518(5,9 \%)$ & $251(8,9 \%)$ \\
Distribuição Cinematográfica & $366(4,1 \%)$ & $190(6,7 \%)$ \\
\hline Total & 8.803 & 2.821 \\
\hline
\end{tabular}

Fonte: Ancine. Elaboração própria.

Distinguindo os pedidos de cinema por gênero, observa-se que 4.576 pedidos $(52 \%$ do total) não estão classificados quanto ao gênero. Analisando, então, apenas os 4.227 pedidos para os quais há indicação de gênero, é evidente como os pedidos de ficção são majoritários e como os documentários, mesmo tendo uma proporção de público reconhecidamente pequena, acumulam uma grande quantidade de pedidos. Além dessas informações, a tabela 3.3 revela uma proporção maior de pedidos com captação do gênero de ficção em comparação à proporção de pedidos recebidos desse gênero.

Outra dimensão interessante de análise da política pública de cinema diz respeito à origem regional dos pedidos de incentivo. Do total dos segmentos de cinema, $80,4 \%$ dos pedidos recebidos proveem do Rio de Janeiro ou de São Paulo, enquanto que $82,2 \%$ dos pedidos contemplados se referem a esses estados. Já a tabela|3.4 é interpretada a partir da comparação das proporções de cada UF com a proporção nacional. Há uma especialização em cinema no estado do RJ conforme a proporção de pedidos do audiovisual concernente 
Tabela 3.3 - Pedidos de cinema por gênero

\begin{tabular}{lcc}
\hline \multicolumn{1}{c}{ Gênero } & Pedidos & Total Capt >0 \\
\hline Ficção & $2.478(58,6 \%)$ & $991(62,9 \%)$ \\
Documentário & $1.558(37,6 \%)$ & $533(33,8 \%)$ \\
Animação & $96(2,3 \%)$ & $45(2,9 \%)$ \\
Programa TV & $33(0,8 \%)$ & $2(0,1 \%)$ \\
Telefilme & $17(0,4 \%)$ & $2(0,1 \%)$ \\
Festival & $9(0,2 \%)$ & $3(0,2 \%)$ \\
Informativo & $6(0,1 \%)$ & $0(0,0 \%)$ \\
\hline Total & 4.227 & 1.576 \\
\hline
\end{tabular}

Fonte: Ancine. Elaboração própria.

a esse setor (75\%) seja sensivelmente superior à proporção indiscriminada em termos estaduais (68\%). Outro estado que se especializa em cinema consiste no Rio Grande do Sul: $72 \%$ dos pedidos correspondem a cinema contra $68 \%$ do total nacional. Ainda para esse estado, observa-se como a sua proporção dos pedidos com captação dos segmentos de cinema (80\%) é superior à mesma proporção nacional (76\%), logo, um pedido de cinema tem probabilidade superior de ser contemplado se provier do estado do RS.

Tabela 3.4 - Pedidos de cinema por UF

\begin{tabular}{lcc|cc|cc}
\hline UF & \multicolumn{2}{c}{ Cinema } & \multicolumn{2}{c}{ Não Cinema } & \multicolumn{2}{c}{ Total } \\
\hline & Pedidos & Total Capt >0 & Pedidos & Total Capt >0 & Pedidos & Total Capt >0 \\
\hline RJ & $3.778(75 \%)$ & $1.316(78 \%)$ & $1.227(25 \%)$ & $368(22 \%)$ & $5.005(100 \%)$ & $1.684(100 \%)$ \\
SP & $3.301(71 \%)$ & $1.002(72 \%)$ & $1.344(29 \%)$ & $389(28 \%)$ & $4.645(100 \%)$ & $1.391(100 \%)$ \\
RS & $336(72 \%)$ & $120(80 \%)$ & $130(28 \%)$ & $30(20 \%)$ & $466(100 \%)$ & $150(100 \%)$ \\
MG & $323(63 \%)$ & $116(78 \%)$ & $187(37 \%)$ & $33(22 \%)$ & $510(100 \%)$ & $149(100 \%)$ \\
Outros & $1017(69 \%)$ & $253(74 \%)$ & $457(31 \%)$ & $87(26 \%)$ & $1.474(100 \%)$ & $340(100 \%)$ \\
ND & $48(6 \%)$ & $14(70 \%)$ & $739(94 \%)$ & $6(30 \%)$ & $787(100 \%)$ & $20(100 \%)$ \\
\hline Total & $8.803(68 \%)$ & $2.821(76 \%)$ & $4.084(32 \%)$ & $913(24 \%)$ & $12.887(100 \%)$ & $3.734(100 \%)$ \\
\hline
\end{tabular}

Fonte: Ancine. Elaboração própria.

Analisando, agora, os valores totais incentivados nas últimas décadas, a figura 3.2 reforça a constatação da seção anterior de que, do total incentivado via renúncia fiscal para o audiovisual, há uma diminuição do peso atribuído ao setor de cinema: a partir de 2007, inicia uma trajetória de queda no total captado a preços constantes para os segmentos de cinema a partir de 2010. Destacam-se, contudo, dois momentos de crescimento na captação de

4 Cabe ressaltar que essa queda também se associa à criação de novos instrumentos de incentivo, como o FSA. 
cinema: o início da segunda metade da década de 1990 e o início dos anos 2000. Enquanto o primeiro período coincide com a consolidação da Lei do Audiovisual, o segundo coincide com a criação da Ancine. Finalmente, decompondo o total de valores incentivados para cinema por ano, destacam-se as seguintes proporções médias: 91\% corresponde a projetos de produção, 67\% ao gênero de ficção e 95\% remetem ao RJ ou SP.

Figura 3.2 - Total captado por ano (em milhões de reais de 2016)

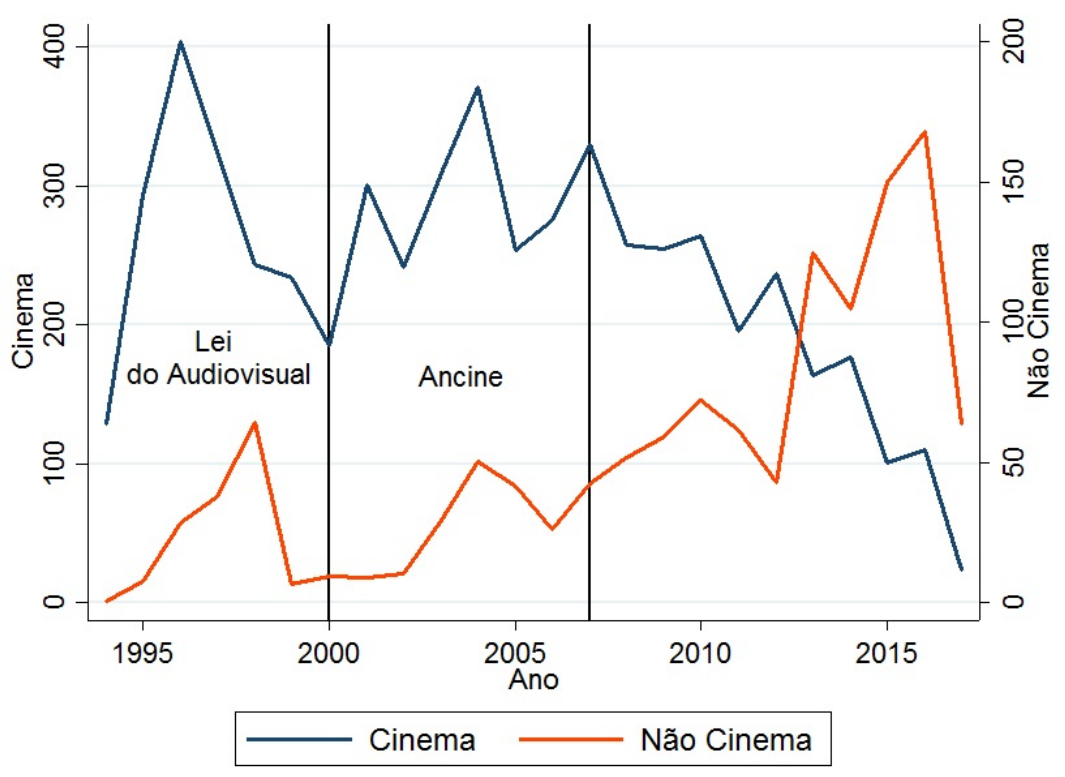

Fonte: Ancine. Elaboração própria.

Em resumo, a política pública de cinema recebe predominantemente pedidos do segmento da produção cinematográfica, o qual também representa uma proporção maior que a esperada dos pedidos contemplados. Os principais gêneros dos projetos de cinema que pleitearam recursos e que foram atendidos são a ficção e o documentário, formatos usuais de filmes de longa-metragem. Já quanto à origem regional, prevalece o incentivo aos estados do Rio de Janeiro, de São Paulo e do Rio Grande do Sul. Por fim, após períodos de crescimento no volume de recursos incentivados, que coincidem com as mudanças institucionais citadas na seção 3.1 , ocorre uma diminuição no total destinado ao incentivo fiscal para o setor de cinema, por volta do fim da década de 2000. 


\subsection{O processo de captação de recursos de incentivo fiscal}

Todo processo de captação sob a Lei do Audiovisual e a Lei Rouanet envolve três agentes principais: a União, investidores ou patrocinadores e produtores de audiovisual. A motivação do poder público, embora não definida explicitamente em lei, consiste em facilitar a produção de obras cinematográficas nacionais, para o que instituiu, através das duas citadas leis, mecanismos de renúncia fiscal. Justamente, a contribuição do Estado parte do não recebimento de quantias devidas e declaradas de imposto de renda. Por simetria, o incentivo de investidores e de patrocinadores reside em participar de um projeto de cinema, tendo em contrapartida a possibilidade de deduzir uma parcela fixada em lei do seu imposto de renda. A tabela 3.5 a seguir resume os principais parâmetros do incentivo fiscal para cada mecanismo disponível e já citado na seção 3.1 . Quanto aos incentivos das produtoras de audiovisual, ficou estabelecido um instrumento não oneroso de financiamento a projetos que até então dependeriam de um crédito bancário não subsidiado.

Tabela 3.5 - Parâmetros do incentivo fiscal sob a Lei do Audiovisual e a Lei Rouanet

\begin{tabular}{|c|c|c|}
\hline Instrumento & Descrição & Limites \\
\hline Artigo $10^{\dagger}$ & $\begin{array}{l}\text { Dedução de IR em } \\
\text { contrapartida a investimentos. }\end{array}$ & $\begin{array}{l}3 \% \text { do IRPF e } 1 \% \text { do IRPJ. } \\
\text { Limitação de } \mathrm{R} \$ 4 \text { milhões por projeto, } \\
\text { para os artigos } 1 \text { o e } 1 \text { oA somados. }\end{array}$ \\
\hline Artigo $1 \mathrm{oA}^{\dagger}$ & $\begin{array}{l}\text { Dedução de IR em } \\
\text { contrapartida a patrocínios. }\end{array}$ & $6 \%$ do IRPF e $4 \%$ do IRPJ. \\
\hline Artigo $3 \mathrm{o}^{\dagger}$ & $\begin{array}{l}\text { Dedução de IRRF* em } \\
\text { contrapartida a investimentos. }\end{array}$ & $\begin{array}{l}70 \% \text { do IRRF. } \\
\text { Limitação de } \mathrm{R} \$ 3 \text { milhões por projeto, } \\
\text { para os artigos } 3 \text { o e } 30 \text { A somados. }\end{array}$ \\
\hline Artigo $3 \mathrm{oA}^{\dagger}$ & $\begin{array}{l}\text { Dedução de IRRF }{ }^{* *} \text { em } \\
\text { contrapartida a investimentos. }\end{array}$ & $70 \%$ do IRRF. \\
\hline Artigo $18^{\ddagger}$ & $\begin{array}{l}\text { Dedução de IR em } \\
\text { contrapartida a patrocínios ou doações. }\end{array}$ & $\begin{array}{l}80 \% \text { de uma doação e } 60 \% \\
\text { de um patrocínio }(\mathrm{PF}) \text { e } 40 \% \\
\text { e } 30 \% \text {, respectivamente }(\mathrm{PJ}) \text {. }\end{array}$ \\
\hline
\end{tabular}

Fonte: Brasil (1991), Brasil (1993). Elaboração própria.

* Imposto de renda retido na fonte devido por empresas distribuidoras e exibidoras ao explorarem domesticamente conteúdos de propriedade estrangeira.

** Semelhante ao artigo anterior, porém, aplicável a empresas que exploraram conteúdo estrangeiro na televisão.

${ }^{\dagger}$ Lei do Audiovisual (Lei 8.685/93).

$\ddagger$ Lei Rouanet (Lei 8.313/91).

O processo do incentivo fiscal para o cinema será ilustrado através dos procedimentos 
necessários para um projeto de produção cinematográfica, embora as etapas abaixo descritas se apliquem também a projetos de distribuição e comercialização. Em um primeiro momento, cabe à empresa proponente o envio do projeto ao Ministério da Cultura ou à Ancine (uma vez iniciada as operações dessa, por volta de 2003). O projeto deve apresentar um requerimento solicitando o exame, o enquadramento e a aprovação do projeto dentro da Lei do Audiovisual ou da Lei Rouanet, conforme o caso (ZAVERUCHA, 1996). Além disso, o projeto deve dispor do contrato social da empresa proponente, da sinopse e justificativa, de um orçamento analítico, discriminando os recursos físicos necessários para a realização do projeto e os seus correspondentes custos, e da enumeração das fontes de receita, incluindo uma contrapartida mínima de $5 \%$ do orçamento global, no caso da Lei do Audiovisual (artigo 4, BRASIL, 1993). Do ponto de vista técnico, deve haver uma cópia do roteiro, um cronograma de execução do projeto e um plano de produção, exigindo-se também currículos da empresa proponente, do produtor e do diretor (ZAVERUCHA, 1996).

Uma vez analisado o projeto pelo Ministério da Cultura ou pela Ancine, essa após o início de suas operações, e tendo sido o projeto aprovado para a captação de recursos via incentivo fiscal, é emitido um Comprovante de Aprovação de Projeto, com validade de 360 dias, que permite o prosseguimento do processo de captação. Então, é necessário o envio do projeto à Comissão de Valores Mobiliários (CVM), no caso do pleito de recursos através dos artigos 1o, 3o e 3oA da lei 8.685, que envolvem o investimento nos projetos, ao invés de patrocínios (artigo 1oA) ou doações (Lei Rouanet). Registrado o projeto na CVM, torna-se possível a compra de cotas de direito de comercialização, certificando o investimento por parte das empresas que desejam compor o incentivo fiscal. Tanto para o investimento quanto para o patrocínio e a doação, a empresa incentivadora deve depositar o valor correspondente em uma conta bancária em nome do beneficiário. O abatimento da quantia ocorre no imposto de renda seguinte, de modo que se configura uma aplicação com possibilidade de retorno (monetário, no caso do investimento, ou de imagem, no caso do patrocínio) de valores que seriam gastos em imposto.

Com a regularização dos recursos na conta bancária, o responsável pelo projeto pode utilizá-los em conformidade com o especificado no projeto inicial, estando a utilização sujeita ao monitoramento pelo Ministério da Cultura ou pela Ancine. Finalizada a obra, essa deve ser registrada e ter uma cópia arquivada junto à Cinemateca Brasileira (artigo 8, 
BRASIL, 1993). Inicia, então, um processo de prestação de contas, em que são analisados pelo órgão competente: o demonstrativo de aportes ao projeto, com a especificação dos totais de cada fonte de recursos, o demonstrativo de despesas e o extrato bancário da conta de referência (ZAVERUCHA, 1996). Caso sejam identificadas irregularidades na aplicação dos recursos, especialmente em termos da não execução do projeto, o artigo 6o da Lei do Audiovisual prevê a devolução da isenção fiscal concedida, com acréscimo de correção monetária e juros. A figura 3.3 resume o processo de captação de recursos de incentivo fiscal.

Figura 3.3 - Fluxograma do pedido de incentivo fiscal

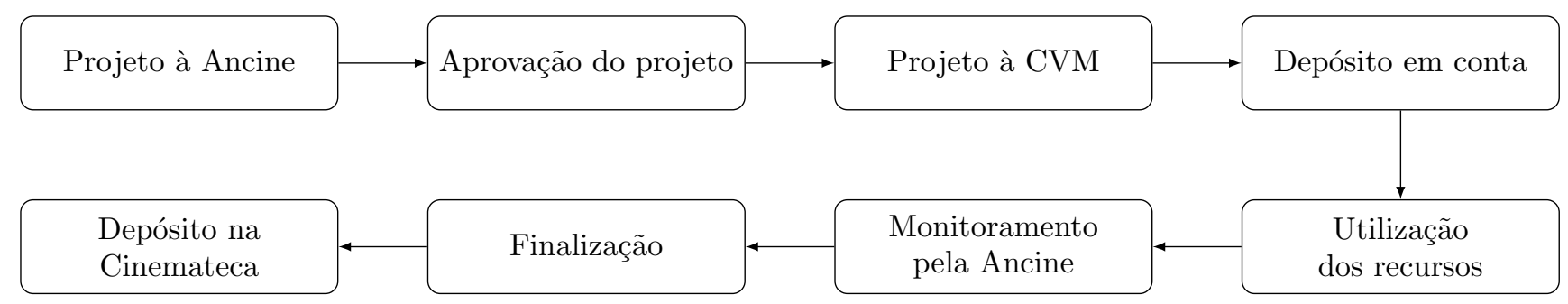

Fonte: Brasil (1991), Brasil (1993), Zaverucha (1996). Elaboração própria.

Os dados do registro de pedidos de incentivo fiscal obtido junto à Ancine contribuem para a compreensão do processo de captação de recursos. Como dito anteriormente, $32 \%$ dos pedidos dos segmentos de cinema foram contemplados entre 1992 e 2017. Uma análise adicional sugere que, no mesmo período, $82 \%$ do total de pedidos contemplados consistiu no primeiro pedido de um projets 5 indicando que os projetos que captam recursos majoritariamente os recebem sem ter pedidos prévios negados, logo, o processo de reconsideração de pedidos tem importância secundária na política de incentivo fiscal. Reforçando essa impressão, apenas $6 \%$ dos pedidos contemplados estão associados a projetos com pedidos negados inicialment ${ }^{6}$.

Distinguindo os pedidos de incentivo para cinema por CNPJ, percebe-se uma grande proporção de empresas criadas para a condução de cada projeto individual, uma vez que $51 \%$ dos CNPJ's registrados (1.294) dispõem de apenas um pedido de incentivo. A tabela 3.6 vai além, demonstrando que $86 \%$ das empresas proponentes acumulam de 1 a 5 pedidos. Quanto às grandes produtoras dos segmentos de cinema, destacam-se a Filmes do Equador e a Gullane Entretenimento, com 57 projetos de cinema cada entre 1992 e

6 O restante da proporção de pedidos contemplados diz respeito a projetos com captação prévia. 
2017 (correspondendo a 75 e 70 pedidos, respectivamente), e a Videofilmes e a Diler \& Associados, com 51 projetos cada (correspondendo a 83 e 70 pedidos, respectivamente).

Tabela 3.6 - Distribuição dos pedidos por CNPJ

\begin{tabular}{lc}
\hline \multicolumn{1}{c}{ Pedidos } & CNPJ \\
\hline Pedidos $=1$ & $1.294(51 \%)$ \\
$1<$ Pedidos $\leq 5$ & $905(35 \%)$ \\
$6 \leq$ Pedidos $\leq 15$ & $279(11 \%)$ \\
$16 \leq$ Pedidos $\leq 30$ & $59(2 \%)$ \\
$31 \leq$ Pedidos $\leq 83$ & $26(1 \%)$ \\
\hline Total & $\mathbf{2 . 5 6 3}$ \\
\hline
\end{tabular}

Fonte: Ancine. Elaboração própria.

Cruzando os dados do número de pedidos com o valor captado médio, para cada CNPJ, apreende-se a associação entre o porte das proponentes e a média de sua captação. A figura 3.4 ilustra a correlação positiva entre ambas as variáveis, confirmando que, de empresas com maior experiência em termos de pedidos enviados, esperam-se maiores valores de incentivo fiscal a seus pedidos. Portanto, as evidências acima sugerem que a captação de recursos para cinema no Brasil notabilizou-se por um número pequeno de grandes produtoras, as quais estiveram mais propensas a quantias incentivadas expressivas.

Colapsando a relação de pedidos de incentivo a fim de se construir uma base de projetos de cinema (que podem dispor de um ou mais pedidos), chega-se ao número de 7.227 projetos entre 1992 e 2017, dos quais 2.360 (33\%) tiveram valor captado positivo ao longo do seu processo de pleito de recursos. Inclusive, entre 1993 e 2017, a média do valor captado foi de $\mathrm{R} \$ 789.901$ por projeto (em reais de 2016 ), ou $\mathrm{R} \$ 2.437 .208$ por projeto (em reais de 2016), considerando apenas os projetos com valor captado positivd 7 .

Com um padrão semelhante ao da tabela|3.6, a tabulação do número de pedidos por projeto mostra grande concentração de projetos com poucos pedidos enviados. Do total de projetos, 6.131 (85\%) dispõem de apenas um pedido de recursos, enquanto que 789 (11\%) apresentam dois pedidos ao longo do seu processo de captação e, consequentemente, apenas $4 \%$ dos projetos tem entre 3 e 9 pedidos. Dessa forma, a prática predominante foi a de envio de apenas um pedido, que, contemplado ou não, evoluiu sem novas tentativas.

7 Analisando as médias ano a ano, observa-se uma trajetória de ininterrupta queda, refletindo, dentre outros fatores, o crescimento proporcionalmente maior do número de projetos que pleitearam recursos ao longo dos últimos anos. 
Figura 3.4 - Número de pedidos e valor captado médio por CNPJ

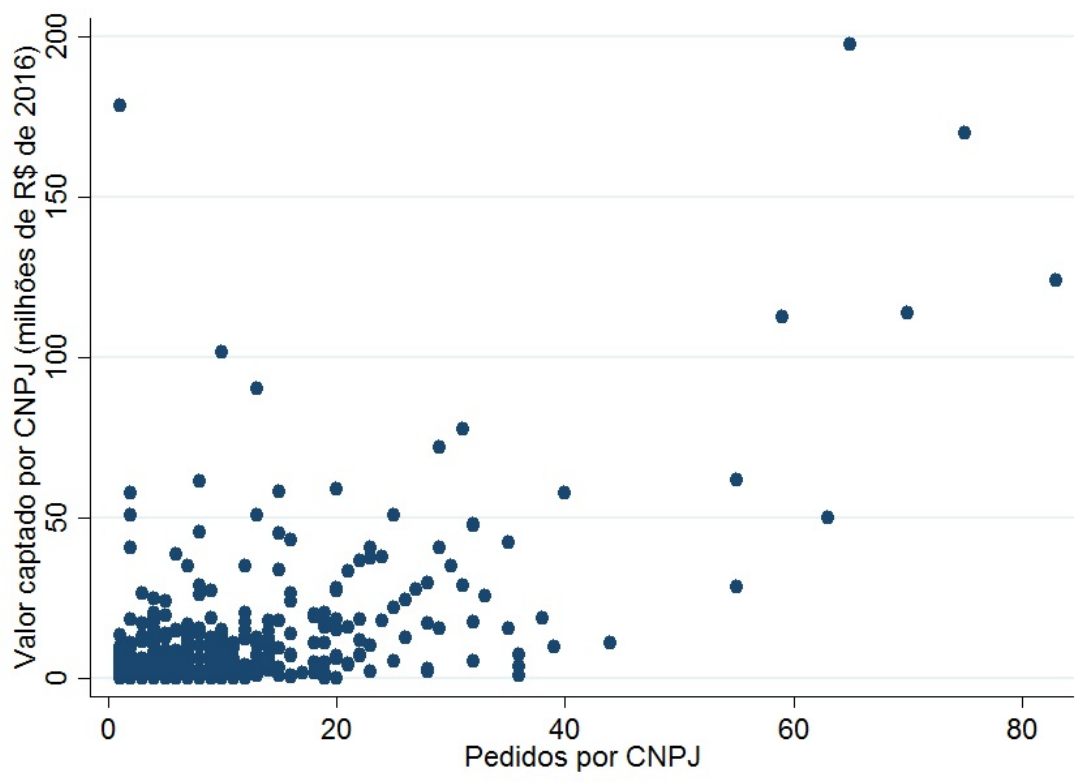

Fonte: Ancine. Elaboração própria.

Analisando, então, a temporalidade do processo de captação, 6.344 projetos (88\%) tiveram pedidos enviados dentro de um mesmo ano. Considerando os demais projetos, isto é, projetos com pedidos enviados em mais de um ano, o tempo médio entre o primeiro e o último pedido de um mesmo projeto é de 3,7 anos, havendo uma amplitude de 1 a 18 anos. Assim, o tempo de desenvolvimento dos projetos é, ao que parece, relativamente grande 8

Considerando a distribuição dos valores por incentivador entre 2007 e 2016, para os mecanismos mais relevantes de fomento para a produção cinematográfica, isto é, considerando os artigos $1^{\circ}, 1^{\circ} \mathrm{A}$ (Lei do Audiovisual) e 18 (Lei Rouanet), observa-se, na tabela 9.1 do anexo, que as cinco principais empresas incentivadoras são estatais, sendo quatro do governo federal (Petrobras, BNDES, Banco do Brasil e FINAME) e uma do governo paulista (SABESP). A Petrobras consiste na principal incentivadora, com investimentos e patrocínios de $\mathrm{R} \$ 185$ milhões (a preços de 2016), correspondendo a $15 \%$ do total desses mecanismos de fomento.

A análise de cada mecanismo separadamente mostra que o principal investidor (artigo $1^{\circ}$ da Lei do Audiovisual) consistiu no BNDES (25\% do total), seguido do Banco do Brasil (11\%), conforme encontrado na tabela 9.2 do anexo. O principal patrocinador

8 Para qualquer projeto, se o primeiro pedido ocorre em $t_{0}$ e o último pedido ocorre em $t_{1}$, então, no mínimo, o tempo entre o início e a conclusão da obra consiste em $\Delta t=t_{1}-t_{0}$. 
através do artigo $1^{\circ} \mathrm{A}$ da Lei do Audiovisual) e o principal incentivador através do artigo 18 da Lei Rouanet consistiu na Petrobras (19\% e 39\% do total, respectivamente), conforme se observa nas tabelas 9.2 e 9.4 . Assim sendo, o investimento foi protagonizado por bancos estatais, enquanto que o patrocínio teve como principal agente a Petrobras. A tabela 9.5 do anexo apresenta que a totalidade dos recursos incentivados entre 2007 e 2016 decorreu, basicamente, de estatais e de empresas privadas, com proporções do total iguais a $51 \%$ e $48 \%$, respectivamente, cabendo às pessoas físicas apenas $1 \%$ do total incentivado.

Finalizando, uma análise dos 114 projetos que não tiveram captação e que são encontrados na base de variáveis de resultado, isto é, que foram lançados e exibidos mesmo sem incentivo fiscal, demonstra que mais de $80 \%$ deles têm exibição posterior ao ano de 2010. Quanto à análise por gênero, $73 \%$ dos projetos sem captação que foram exibidos correspondem aos gêneros do documentário (42\%) e do drama (31\%). Desperta a atenção a considerável proporção de filmes exibidos sem captação que não estão associados a grandes produtoras $(95 \%)$ ou a diretores experientes no mercado (84\%), sendo que as proporções gerais da base de variáveis de resultado são, respectivamente, $82 \%$ e $78 \%$.

Portanto, o que a exposição dos dados de pedidos de incentivo fiscal para o cinema indicou quanto ao processo de captação de recursos se resume a: i) a reconsideração de pedidos tem importância secundária na política de incentivo fiscal, uma vez que os projetos que captam valores essencialmente os fazem através de um primeiro e único pedido; ii) há poucos proponentes com grandes quantidades de pedidos enviados, sendo que esses mobilizam montantes maiores de recursos; iii) os projetos tendem a remeter de um a dois pedidos, porém, daqueles com mais de um pedido, infere-se um prazo longo para a finalização da obra.

\subsection{O funcionamento da Ancine}

A Agência Nacional do Cinema foi instituída, conforme visto na seção|3.1, pela Medida Provisória 2.228-1 de 2001, a qual redesenhou a política pública de cinema no país ao definir os objetos de incentivo, os mecanismos, inclusive ampliando o prazo da Lei do Audiovisual (artigo 50, BRASIL, 2001), e, sobretudo, ao instituir medidas de regulação e de fiscalização sobre o setor. Mais do que isso, a MP que criou a Ancine estabeleceu, em seu artigo 2o, os princípios da Política Nacional do Cinema. Assim, ficaram formalizadas 
as intenções gerais da política pública de cinema no país.

A ampliação do acesso a obras nacionais, fundamentalmente, representa o cerne da política, conforme "a promoção da cultura nacional e da língua portuguesa" seja buscada através do "estímulo ao desenvolvimento da indústria cinematográfica e audiovisual nacional" (BRASIL, 2001). Ademais, outro princípio geral da política é definido diretamente pela intenção de garantir a "presença de obras cinematográficas e videofonográficas nacionais nos diversos segmentos de mercado"(BRASIL, 2001). Dessa forma, discernindo o mercado nacional de cinema entre oferta e demanda, e concebendo essas últimas como, respectivamente, as condições de acesso ao produto nacional e o conjunto de preferências do consumidor de cinema, entende-se que a política pública tenha como prioridade os parâmetros da oferta de filmes nacionais.

Com o objetivo principal de conduzir a Política Nacional do Cinema, o artigo 3o da MP 2.228-1 criou o Conselho Nacional do Cinema, que tem por uma de suas atribuições, inclusive, o estímulo à presença de conteúdo nacional na totalidade das veiculações possíveis, reforçando ser a oferta de filmes nacionais o foco da política pública. O artigo 4o lista a composição do Conselho, que mescla membros do setor público com representantes da sociedade civil. Além de ministros como o da Justiça, das Relações Exteriores e da Cultura, compõem o órgão o chefe da Casa Civil da Presidência, que preside o Conselho, e cinco representantes da indústria cinematográfica nacional, designados por decreto.

Quanto aos objetivos da criação da Ancine, o artigo 6o demonstra coerência com relação às diretrizes gerais da política de cinema. Predominam os objetivos de desenvolvimento da cadeia produtiva do cinema nacional, com intenções como a de aumentar a competitividade da indústria doméstica e a de promover a sua sustentabilidade, tendo por fim "o aumento da produção e da exibição das obras cinematográficas brasileiras" (BRASIL, 2001). Também o objetivo de universalizar o acesso ao cinema deixa explícito a intenção de que isso ocorra sobretudo para as obras nacionais. Portanto, toda a atuação da agência, com suas incumbências de regulação, de fiscalização e, principalmente, de promoção do fomento, volta-se para a ampliação da oferta e, com isso, do consumo de filmes nacionai:9? Expandir o conjunto de produções nacionais exibidas no país anualmente e elevar

9 Embora a melhoria da qualidade dos filmes nacionais também seja estimulada, a legislação prioriza o atendimento de uma demanda que se considera já existente, porém, que se defronta com uma oferta insuficiente. 
o público médio dessas resumem os objetivos do funcionamento da Ancine.

A estrutura da agência é comandada por uma diretoria composta por um diretorpresidente e por três diretores, com mandatos de quatro anos (artigo 8, BRASIL, 2001), estando o histórico de gestão da agência descrito em seção abaixo. Já o seu funcionamento é financiado, principalmente, através do produto de multas arrecadadas com o exercício das atribuições de fiscalização e através de dotações consignadas pelo Orçamento-Geral da União (artigo 11, BRASIL, 2001). Adicionalmente, constituem fontes de recursos para o investimento direto através do FSA: uma parcela da arrecadação da Contribuição para o Desenvolvimento da Indústria Cinematográfica Nacional (Condecine), que incide sobre diversas atividades do setor de cinema (produção, distribuição, veiculação, etc.), o produto da arrecadação de multas e juros, a remuneração decorrente de investimentos prévios e transferências da União, estados e municípios (artigo 48, BRASIL, 2001).

Quanto às atribuições de fomento às atividades cinematográficas, essas iniciaram com a própria condução da análise dos projetos enviados para pleito de incentivos fiscais por meio das Leis do Audiovisual e Rouanet, uma vez que os artigos 49 e 67 transferiram para a Ancine a incumbência da aprovação dos pedidos de renúncia fisca 10 . Ao nível da regulação, o artigo 22 instituiu que todas as empresas de produção, distribuição e exibição cinematográficas operando no Brasil (nacionais ou estrangeiras) devem ser registradas junto à agência, principalmente aquelas nacionais que visem se beneficiar de recursos públicos. Não somente isso, o artigo 28 requer o registro de toda obra cinematográfica nacional, antes de sua exibição ou comercialização, ao que se segue a atribuição de um Certificado de Produto Brasileiro. No mesmo sentido, o artigo 23 estabeleceu que toda produção estrangeira em território nacional deve ser comunicada à agência. Já o artigo 25 exige o pagamento da Condecine previamente à exibição de qualquer obra estrangeira no país. Uma medida de regulação que visa à supervisão do mercado partiu do artigo 17, que impõe a obrigatoriedade de que todo espaço de exibição cinematográfica disponha de um sistema de controle de bilheteria.

Algumas medidas de regulação extrapolam o monitoramento do setor, instituindo formas de reserva de mercado no setor de cinema brasileiro. O artigo 55, por exemplo, define a obrigatoriedade de que as empresas exibidoras de obras cinematográficas exibam filmes brasileiros "por um número de dias fixado, anualmente, por decreto"(BRASIL,

$\overline{10}$ A isenção da Condecine (artigo 39, BRASIL, 2001) também tem o seu pedido avaliado pela Ancine. 
2001), sendo que a "Ancine aferirá, semestralmente, o cumprimento do disposto neste artigo" (BRASIL, 2001). O artigo 56 versa sobre um segmento de atividade já obsoleto, porém, importante na primeira metade da década de 2000. Define a obrigatoriedade de que as empresas de distribuição de video doméstico (videolocadoras) tenham um percentual anual mínimo de obras brasileiras, proporção essa também estabelecida anualmente por decreto. A MP 2.228-1 torna possível a extensão dessas formas de reserva de mercado para outros segmentos de exibição, a serem escolhidos futuramente e conforme o arbítrio da agência.

Visando ao enforcement das normas regulatórias do setor citadas acima, foram incluídas como atribuições da Ancine medidas de fiscalização. Enquanto o artigo 58 estabelece a possibilidade de punições para o descumprimento das disposições da MP, o artigo 59 particulariza a punição aos infratores do disposto no artigo 55, conforme empresas exibidoras tenham de pagar uma multa de $5 \%$ da receita bruta média diária de bilheteria, tendo por referência o ano da infração, multiplicado esse valor pelo número de dias de descumprimento (artigo 59, BRASIL, 2001). O artigo 60, por sua vez, estabelece multa de $\mathrm{R} \$ 2.000$ a $\mathrm{R} \$ 2.000 .000$ para o descumprimento de uma série de artigos da MP, dentre eles o artigo 56, que cria a reserva de mercado para o segmento de videolocadoras. O artigo 61, por fim, impõe sanções monetárias a projetos financiados com recursos do FSA e cuja execução ocorra em desconformidade ao proposto inicialmente.

Quanto à promoção do fomento às atividades cinematográficas, complementando o controle do incentivo fiscal e do investimento direto, destacam-se medidas adicionais de promoção. O Prêmio Adicional de Renda (PAR), instituído pelo artigo 54 e lançado em 2005, consiste em um incentivo financeiro a obras inscritas em editais anuais e escolhidas por um conjunto de servidores técnicos da Ancine, nomeados pela diretoria da agência. Um segundo mecanismo criado para a ampliação dos instrumentos de incentivo foi o Programa Ancine de Incentivo à Qualidade (PAQ). Estabelecido em 2006 por uma instrução normativa interna, esse programa premia obras cinematográficas nacionais escolhidas pelo corpo técnico da agência dentre um conjunto de produções vencedoras, ou participantes da principal mostra competitiva, de festivais que dispunham de um juri oficial. Finalmente, outras medidas de promoção do cinema nacional envolvem justamente o incentivo à realização de festivais e mostras de cinema, os quais podem solicitar isenção da Condecine, além de poderem contar com o apoio de divulgação por parte da agência. 
Quanto a festivais internacionais, a Ancine auxilia na escolha das obras que concorrem nos principais circuitos, bem como financia os custos de inscrição e participação.

Finalizando a descrição do conteúdo da legislação de criação da Ancine, embora a medida provisória pertinente seja de 2001, o seu próprio conteúdo prevê um intervalo de tempo para o início das operações. Além de um prazo de quatro meses, contados a partir de setembro de 2001, para a instalação da agência (artigo 70, BRASIL, 2001), o tempo previsto na medida provisória para a constituição do seu funcionalismo próprio foi de dois anos, uma vez realizada a instalação da agência.

\subsubsection{Início das atividades da Ancine e primeiras medidas de regulação e de fomento}

São apresentadas, agora, evidências do início pleno das atividades da Ancine e do início da vigência das medidas de regulação e de fomento. As informações que servem de base às conclusões proveem de documentos da Ancine que registram as suas deliberações: resoluções da diretoria colegiada $(\mathrm{RDC}){ }^{11}$ e instruções normativas $(\mathrm{IN})^{12}$.

Uma das primeiras resoluções de diretoria aprovadas sugerem o último terço do ano de 2002 como correspondente ao começo das atividades básicas da agência, uma vez que, em 20 de setembro de 2002, a RDC 02/2002 definia diretrizes e procedimentos quanto à comunicação telefônica. A primeira deliberação operacional remonta a 12 de novembro de 2002, data na qual foi aprovada a RDC 03/2002, que dispõe sobre o processo de apreciação pela diretoria colegiada de pedidos de incentivo fiscal. A RDC 05/2002 estabelecia ainda procedimentos gerais de reunião e de decisões para a diretoria colegiada. Em 17 de janeiro de 2003, estabeleciam-se procedimentos para a prestação anual de contas ao TCU (RDC 06/2003).

Uma nova resolução relevante quanto à aprovação da concessão de incentivos viria apenas em 25 de fevereiro de 2003, com a RDC 09/2003. As últimas deliberações administrativas iniciais remontam a 2004: a RDC 14/2004 define procedimentos para os protocolos da Ancine e a RDC 16/2004 normatiza a administração do patrimônio da agência. A análise das deliberações administrativas iniciais, portanto, permite a estimação do ano de 2004 como o primeiro em que a Ancine pôde atuar integralmente.

11 Fonte: https://www.ancine.gov.br/pt-br/legislacao/resolucoes-diretoria-colegiada.

12 Fonte: https://www.ancine.gov.br/pt-br/legislacao/instrucoes-normativas-consolidadas. 
As instruções normativas aprovadas pela diretoria colegiada configuram medidas de regulação e de fomento partindo da legislação existente, tornando-a aplicável de acordo com parâmetros especificados pela agência. Uma estimativa para o início da vigência dessas medidas é possível ao serem consideradas as datas de aprovação de importantes instruções normativas. Ademais, classificam-se as instruções de acordo com três categorias gerais: monitoramento, reserva de mercado e fomento.

As primeiras instruções normativas pertinentes ao monitoramento do setor se concentram nos anos de 2002 e de 2004. A IN 02/2002, de 22 de maio de 2002, normatiza o registro de empresas, importante sobretudo para a concessão de incentivos para produções brasileiras. A IN 04/2002 e a IN 05/2002, de 29 de maio de 2002, dispõem acerca do registro de obras cinematográficas, o que se aplica ao recolhimento da Condecine. Ao término do ano de 2002, outra instrução de registro de atividades foi aprovada: a IN 11/2002 normatiza a emissão do Certificado de Produto Brasileiro.

Uma segunda leva de instruções com finalidades de monitoramento é registrada em 2004: são aprovadas a IN 28/2004 (normas para a utilização da logomarca da Ancine nas obras cinematográficas incentivadas e em seus materiais de divulgação), a IN 30/2004 (regulamentação dos procedimentos de aplicação de penalidades) e a IN 32/2004 (regulamentação da filmagem em território nacional de obras cinematográficas estrangeiras). As últimas instruções relevantes aprovadas dizem respeito à obrigatoriedade de envio à agência de relatórios setoriais: IN 51/2006 (exibição cinematográfica), IN 64/2007 (segmento de vídeo doméstico) e IN 65/2007 (segmento de salas de exibição).

Como as seguintes instruções normativas de monitoramento são secundárias ou consistem em alterações de dispositivos de instruções anteriores, conclui-se que o processo básico de constituição de medidas de regulação com a finalidade de monitoramento do setor foi finalizado no ano de 2004.

Apenas em 2004 surgem instruções normativas acerca da regulação que assume a forma de reserva de mercado para a exibição cinematográfica. A IN 27/2004 regulamenta o cumprimento da obrigatoriedade de exibição de filmes nacionais para o ano de 2004, apresentando o número de dias mínimo com títulos nacionais em exibição, arbitrando as possibilidades de transferência de dias entre complexos de cinema de um mesmo grupo e, principalmente, dispondo quanto aos relatórios de cumprimento da obrigatoriedade e 


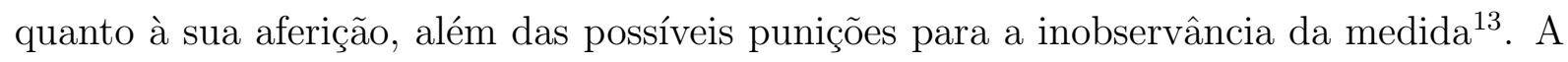
IN 38/2005, a IN 48/2006 e a IN 58/2007 têm conteúdo equivalente ao da instrução anterior, porém, aplicam-se para os anos de 2005, 2006 e 2007, respectivamente. Para os anos seguintes, não se encontram instruções ano-específicas quanto à reserva de mercadd ${ }^{14}$. A IN 67/2007 e a IN 88/2010, no entanto, apresentam regulamentações gerais para o cumprimento da obrigatoriedade de exibição, estando indefinido o período de vigência dessas medidas.

Mesmo que o artigo 55 da MP 2.228/01, que versa sobre a reserva de mercado para a exibição de filmes nacionais, tenha validade desde 2001, há a normatização dos procedimentos pertinentes de regulação e de fiscalização apenas a partir de 2004. Portanto, é razoável estabelecer esse ano como o período de início da aplicabilidade da forma de tratamento em que consiste a reserva de mercado para o produto nacional.

As instruções normativas relevantes e que se referem a mecanismos de fomento foram aprovadas até o ano de 2004. A primeira delas, a IN 12/2002 regula de um modo geral o processo de captação de recursos de incentivo fiscal, motivação semelhante à das instruções IN 20/2003, IN 22/2003 e IN 61/2007 (essa última específica para o segmento de mercado das salas de exibição). Com abordagens mais específicas, a IN 19/2003 e a Decisão Conjunta 01/2004 entre a Ancine e a CVM, normatizam a distribuição e a comercialização de Certificados de Investimento em projetos de audiovisual.

A IN 23/2004, por sua vez, normatiza a classificação das empresas proponentes de pedidos de incentivo fiscal, enquanto que a IN 21/2003, a IN 34/2004 e a IN 37/2004 se referem à supervisão pela agência do processo de captação de recursos. Por fim, a IN 44/2005 e a IN 56/2006 normatizam novos programas de incentivo: o Prêmio Adicional de Renda (PAR) e o Programa Ancine de Incentivo à Qualidade (PAQ), respectivamente.

Como as instruções normativas concernentes ao fomento são, após 2004, secundárias ou compostas de alterações de instruções anteriores (à exceção da IN 44/2005 e da IN 56/2006, que normatizam novos instrumentos de incentivo, e da IN 61/2007, que estende normas a um novo segmento do mercado), conclui-se que a atuação da Ancine de promoção dos mecanismos de fomento, em especial, com relação ao incentivo fiscal, inicia

13 As punições previstas na IN 27/2004 vão além da cobrança de multa prevista pelo artigo 59 da MP 2.228-01: o artigo 12 da instrução indica como punição a restrição por seis meses à participação da empresa infratora em programas de fomento.

14 Como as instruções normativas são numeradas, é razoável acreditar que, de fato, nenhuma instrução de reserva de mercado ano-específica anterior a 2004 ou posterior a 2007 exista, uma vez que na listagem de instruções não há quebra na sequência numérica. 
plenamente a partir de 2004 .

Dessa forma, é razoável considerar o ano de 2004 como sendo aquele a partir do qual a Ancine pôde atuar visando à aplicação de uma legislação de proteção e de incentivo à indústria brasileira de cinema.

Em resumo, no seu pleno funcionamento, a agência dividia suas funções entre a regulação, destacando-se as citadas reservas de mercado, a fiscalização e a promoção do fomento, esse que foi diversificado ao longo do tempo para além do então já existente incentivo fiscal, o qual passou integralmente à sua gestão.

\subsubsection{Evidências de enforcement das medidas de regulação e de fiscalização}

Como demonstrado anteriormente, a reserva de mercado que determina a obrigatoriedade de exibição de filmes nacionais consiste na principal medida de regulação dentre as criadas pela Ancine. Assim, é conveniente a sua descrição e a enumeração de seus principais parâmetros. Além disso, visando evidenciar o enforcement da medida, são expostos números de cumprimento e de descumprimento, bem como de penalizações. Por fim, são expostos números de penalizações que sugerem o enforcement pela agência de outra medida de fiscalização importante: a supervisão quanto a irregularidades na aplicação de recursos de incentivo fiscal.

A obrigatoriedade da exibição de filmes nacionais por um número mínimo de dias foi definida pelo artigo 55 da MP 2.228-1, embora a reserva de mercado para o setor tenha um vasto histórico no paít ${ }^{15}$ O artigo 55 e, antes desse, o artigo 29 da lei 8.401/92 preveem que o Presidente da República estabeleça por decreto os números de dias mínimos para a obrigatoriedade de exibição.

Com o funcionamento da Ancine, essa, através de uma série de instruções normativa: ${ }^{16}$, definiu uma regulamentação específica para a validade da reserva de mercado e, principalmente, para a garantia de seu cumprimento: indicação dos agentes econômicos sujeitos à medida, possibilidade de transferência de dias entre complexos de cinema de um mesmo grupo, envio de relatórios de cumprimento da obrigatoriedade, aferição pela Ancine, penalizações administrativas, etc.

$\overline{15}$ A primeira ocorrência remonta a 1932, para filmes educativos, e a 1937, para longa-metragens (ANCINE, 2017).

16 Listadas anteriormente: IN 27/2004, IN 38/2005, IN 48/2006, IN 58/2007, IN 67/2007 e IN 88/2010. 
Os decreto: ${ }^{17}$ que estabelecem os números de dias mínimos apresentam a discriminação dos dias exigidos por tamanho do complexo de cinema, mensurado pelo número de salas: $\sqrt{18}$ (de 1 a 11 e mais de 11 salas). Portanto, não se trata de uma exigência indiscriminada, uma vez que as empresas exibidoras devem cumprir dias de acordo com o seu porte.

Observa-se que, com o decorrer do tempo, foi sendo aperfeiçoado o sistema denominado "Cota de Tela", a forma pela qual a Ancine faz referência à reserva de mercado para a exibição cinematográfica. Para ampliar a diversidade de filmes nacionais com exibição obrigatória, instituiu-se um mínimo de obras distintas para cada tamanho de complexo (a partir de 2003) e um máximo de salas que exibem um mesmo filme (a partir de 2015). Se essas alterações expandiram a disponibilidade de filmes nacionais ao ampliar o conjunto de obras em exibição, ocorreram também elevações nos dias mínimos de obrigatoriedade.

Por exemplo, um complexo como o Caixa Belas Artes, em São Paulo-SP, que hoje dispõe de 6 salas de exibição, deveria exibir produções nacionais durante: 154 dias no ano, em 2001 e 2002; 217 dias, em 2003; e 378 dias, entre 2005 e 2017. Importante esclarecer que o número de 378 dias de exibição em um ano representa que no mínimo dois filmes nacionais distintos devem ser exibidos em um dado ano (um durante 365 dias e outro durante 13 dias, por exemplo). Portanto, a própria cota de dias de exibição tende a expandir o conjunto de obras em exibição.

Exemplificando a totalidade dos parâmetros que regem atualmente a Cota de Tela, um cinema de grande escala, como o Cinemark do Shopping Internacional de Guarulhos, que dispõe de 15 salas de exibição, deve ter exibido, em 2017, no mínimo 23 filmes nacionais distintos, com no máximo 5 salas exibindo um mesmo título, sendo que a exibição nacional deve ter alcançado, pelo menos, 675 dias. Novamente, isso representa que cada um dos 23 títulos distintos obrigatoriamente exibidos devem ter estado em cartaz por pelo menos 30 dias cada.

Mesmo com a impossibilidade de obtenção de dados que demonstrem a heterogeneidade dos impactos da reserva de mercado por município, isto é, por porte de município, a análise dos decretos de Cota de Tela apresentados acima sugere uma clara distorção na obrigatoriedade de exibição de filmes nacionais. Os decretos para os anos de 2016 e 2017

\footnotetext{
17 Entre 2001 e 2017, ininterruptamente, foram publicados decretos anuais estabelecendo o número de dias mínimo para o cumprimento da exibição obrigatória de filmes nacionais.

18 À exceção do ano de 2004, que definiu indiscriminadamente a obrigatoriedade de exibição por 63 dias.
} 
exigem, proporcionalmente ao número de salas, um maior número mínimo de títulos nacionais distintos para complexos exibidores menores (figura|9.1[(a) do anexo) e um número mínimo de dias de exibição que, após um máximo de dias por sala para complexos com 6 e 7 salas, é decrescente com o tamanho do complexo (figura|9.1[(b) do anexo).

A própria implementação da regulação, portanto, implica em uma obrigatoriedade proporcionalmente menor para complexos exibidores de maior magnitude, que tendem a se concentrar em municípios igualmente maiores. Além disso, exige-se uma maior exibição de filmes nacionais em complexos e, por conseguinte, em municípios cujo volume de público tende a ser menor.

Com uma adequada compreensão da reserva de mercado, é importante ter evidências de que os agentes econômicos implicados de fato cumpriram as medidas impostas. Está disponível, para os anos de 2010 a 2015, o "Relatório Cota de Tela", que apresenta estatísticas de cumprimento e de descumprimento da exibição obrigatória de filmes nacionais. Adicionalmente, em 2017 foi produzido o "Relatório de Análise de Impacto da Cota de Tela" (ANCINE, 2017), que traz informações consolidadas sobre a adimplência da obrigatoriedade de exibição.

A tabela 9.6 do anexo, construída a partir dos Relatórios de Cota de Tela para os anos de 2010, 2014 e 2015 19 , apresenta que a proporção média de cumprimento para os três anos é de 84,7\%. Além disso, enquanto que a média de descumprimento da cota corresponde a 5,5\%, a média de descumprimento por não envio do relatório de supervisão é de $9,7 \%$, indicando que a principal forma de inadimplência da obrigatoriedade consiste em um fator mais geral do que o efetivo descumprimento, dado que os exibidores que não enviam o relatório podem fazê-lo por razões administrativas. Considerando a inadimplência por tamanho do complexo exibidor, a tabela 9.7 do anexo demonstra que o descumprimento da medida de reserva de mercado é destacadamente superior para complexos pequenos, com até 5 salas de exibiçã 20 .

Finalizando a descrição do enforcement da obrigatoriedade de exibição de filmes nacionais, expõem-se, na tabela 9.8 do anexo, valores de multas aplicadas em virtude do descumprimento da Cota de Tela, informações essas que foram obtidas como resposta a

19 Os anos de 2011, 2012 e 2013 apresentam informações apenas preliminares, correspondentes ao primeiro semestre de cada ano. Como as empresas exibidoras postergam para o segundo semestre o cumprimento total da obrigatoriedade, as informações dos relatórios daqueles anos são distorcidas.

20 O processo de aferição pela Ancine envolve a checagem dos relatórios enviados, os quais são construídos com base em um sistema eletrônico de monitoramento de bilheteria regulado pela agência. Eventualmente, a Ancine pode decidir por fiscalizações físicas dos complexos. 
uma solicitação de acordo com a Lei do Acesso à Informação (lei 12.527/11). A despeito da baixa magnitude dos valores, trata-se de mais uma evidência favorável ao enforcement da reserva de mercado.

A mesma resposta da Ancine a uma solicitação por informações levou à tabela 9.9 do anexo. Estão listados, por ano entre 2007 e 2017, os valores devolvidos por conta de irregularidades na aplicação dos valores captados com incentivo fiscal sob a Lei do Audiovisual. Novamente, trata-se de uma indicação de que a Ancine fiscaliza a utilização dos recursos incentivados tal como previsto pelo artigo 6 da lei 8.685/93 (vide a descrição do processo de captação de recursos na seção 3.4 .

Desse modo, anteriormente foi levantada uma série de medidas de regulação e de fiscalização que a Ancine protagoniza e que tem a capacidade de impactar variáveis de resultado do setor de cinema. A efetividade dessas medidas em cumprir seus objetivos de promoção da indústria nacional, porém, depende do grau com que os agentes econômicos de fato respondem a elas. Ainda que com extensão temporal e detalhamento limitados, as evidências acima sugerem que há o enforcement das seguintes medidas: obrigatoriedade de exibição de filmes nacionais e monitoramento pela Ancine da aplicação dos valores captados com incentivo fiscal.

\subsubsection{Histórico de gestão da Ancine}

Embora a medida provisória de criação da Ancine remonte ao governo de Fernando Henrique Cardoso, do Partido da Social Democracia Brasileira (PSDB), cujos mandatos consecutivos compreendem o período de 1994-2002, o início das operações da agência, por volta de 2003/2004, coincide com o primeiro governo do Partido dos Trabalhadores (PT).

A política brasileira de cinema do pós-Ancine foi coerente com as conhecidas diretrizes econômicas gerais dos governos do período de 2003-2016, voltadas à ampliação do consumo das famílias e à descentralização regional da economia. O objetivo central da política de cinema de ampliação do acesso do consumidor brasileiro a filmes nacionais culmina, em última instância, no crescimento do consumo desse produto. Além disso, mesmo que não pertença ao escopo desta pesquisa, a política pública consubstanciada no Programa Cinema Perto de Você (PCPV) se direciona preferencialmente para estados à exceção do Rio de Janeiro e de São Paulo, havendo atenção especial para os estados do 
Nordeste e do Norte21.

Com relação à gestão específica da Ancine, houve notória estabilidade no seu comando. De 2002 a 2017, contabilizam-se apenas três presidentes, cujos mandatos são de quatro anos. O cineasta Gustavo Dahl ${ }^{22}$ foi presidente da Ancine entre 2002 e 2006, sucedido, então, por outro cineasta, Manoel Range ${ }^{23}$, que presidiu a agência de 2006 a 2017. Com as recomposições ministeriais do governo de Michel Temer, Rangel foi substituído por Christian de Castro Oliveird24. Os dois primeiros presidentes dispuseram de experiência prévia como gestores de órgãos burocráticos no setor, enquanto que o primeiro e o último não apresentavam envolvimento político-partidário explícito.

Como enunciado anteriormente, a diretoria da Ancine é composta pelo diretorpresidente e por outros três diretores, que também dispõem de mandatos de quatro anos. Os currículos de alguns dos últimos diretores apontam para a predominância de cineastas e de ex-funcionários do setor público. Da diretoria colegiada atual, por exemplo, dos três diretores (excluindo o diretor-presidente), dois têm histórico exclusivo de funcionalismo público ${ }^{25}$ e apenas um teve experiência no setor privado da indústria de cinema 26 .

Portanto, do exposto acima, embora alinhado às diretrizes gerais de governo e mesmo que voltado para os interesses do setor de cinema, o funcionamento da Ancine foi conduzido por gestores públicos e por cineastas. Ainda assim, é importante a ressalva de que uma robusta e metodológica análise de Economia Política foge do escopo do presente trabalho, de modo que as informações disponibilizadas acima têm apenas uma finalidade ilustrativa.

$\overline{21}$ Além disso, o item VI do artigo 6 da MP 2.228-1 (BRASIL, 2001) expõe a intenção da atuação da Ancine de promover uma produção cinematográfica brasileira diversificada regionalmente.

22 Cineasta de carreira, envolveu-se em mais de um momento com a burocracia do setor de cinema: foi presidente da Associação Brasileira de Cineastas (1981-1983) e do Concine (1985-1987).

23 Igualmente com histórico prévio como burocrata no setor (presidente da Associação Brasileira de Documentaristas de São Paulo entre 1999 e 2001, e da Comissão Estadual de Cinema da Secretaria da Cultura de São Paulo entre 2001 e 2002). Manoel Rangel era filiado ao Partido Comunista do Brasil (PCdoB), da base governista no período 2003-2016.

24 Com atuação exclusiva no setor privado, trabalhou junto a empresas de economia criativa em seus processos de captação de recursos, na medida em que prestava serviços de consultoria.

25 Alex Braga Muniz atuou na Advocacia-Geral da União (AGU) de 2002 a 2017 e, dentro da própria Ancine, de 2003 a 2017, como Procurador Federal junto à agência.

Mariana Ribas atuou Secretaria Municipal de Cultura do Rio de Janeiro de 2003 a 2011, ano a partir do qual assumiu a gerência de Fomento da RioFilme. Também ocupou mais de um cargo no Ministério da Cultura.

26 Debora Ivanov foi, no período de 2009 a 2015, diretora do Sindicato da Indústria do Audiovisual do Estado de São Paulo (SIAESP). Foi sócia da Gullane Entretenimento, uma das maiores empresas de audiovisual do país, de 2000 a 2015. 


\subsection{O investimento direto através do FSA}

O Fundo Setorial do Audiovisual (FSA), criado em 2006 e com operações iniciando em 2008, marca uma segunda fase do fomento às atividades audiovisuais brasileiras. Constituído fundamentalmente por recursos da Condecine (artigo 34, BRASIL, 2001), o fundo atua, conforme exposto na seção 3.1 , com base em três programas: Prodecine (produção e distribuição de cinema), Prodav (produção e distribuição de televisão) e Programa Cinema Perto de Você (exibição de cinema). Conforme exposto no seu documento de diretrizes, a razão para a criação do FSA decorre da necessidade de um instrumento complementar e diferenciado de política pública visando ao desenvolvimento sustentado da indústria de cinema brasileira, em consonância com as intenções da política nacional (FSA, 2008).

A busca pela diversificação dos instrumentos de incentivo é explícita no documento de diretrizes, reforçando que o modelo então vigente, fundamentado no incentivo fiscal, embora tenha sido capaz de ampliar a produção nacional, apresentou algumas deficiências. Uma das mais prementes justifica a definição de uma forma de incentivo baseada no investimento, ao invés da renúncia fiscal: a "dependência de recursos não reembolsáveis" (FSA, 2008). Outros gargalos que a atuação do fundo visa enfrentar são a frágil articulação entre os setores da produção e da distribuição de cinema e o relativamente pequeno apoio até então dado aos outros setores da cadeia produtiva exceto a produção, como a distribuição e, principalmente, a exibição. Portanto, também almejando a melhoria das condições de oferta de filmes nacionais, o FSA teve por referência a diversificação, tanto dos instrumentos de incentivo, a fim de diminuir a dependência de recursos não retornáveis, quanto dos setores da cadeia produtiva que são objetos de fomento.

A determinação do valor incentivado ao longo do processo de captação junto ao FSA será ilustrada através de um procedimento padrão de investimento, embora a atuação do fundo envolva também formas de apoio não reembolsáveis e financiamentos. O investimento em cinema é composto por três linhas de incentivo pertencentes ao Prodecine: a linha $\mathrm{A}$, que diz respeito à produção cinematográfica, a linha $\mathrm{C}$, voltada à distribuição cinematográfica, e a linha $\mathrm{D}$, que se destina à comercialização de obras cinematográficas. O investimento em TV, por sua vez, é composto por uma única linha do Prodav, dedicado à produção de conteúdo audiovisual televisivo. Além de editais anuais, muitos dos quais têm propósitos de fomento específicos, como o incentivo à coprodução com países latinoamericanos ou ibéricos, todos os programas citados acima têm editais de fluxo contínuo, 
que podem receber pedidos de investimento ao longo de todo o ano.

O incentivo às produtoras para a participação do fomento do FSA consiste em uma nova forma não onerosa de captação de recursos para a execução de projetos. Além disso, diferentemente do incentivo fiscal, o investimento através do fundo tem custos de transação menores, uma vez que não há a necessidade da busca por uma empresa incentivadora. O processo de captação inicia com o envio do projeto à Ancine, dispondo de informações semelhantes às expostas na seção 3.4 para o incentivo fiscal. A seleção utiliza de um sistema de pontuação para os projetos, a depender da qualificação atribuída à produtora, à distribuidora e ao diretor, além do mérito do projeto em si. Tais procedimentos eliminam e classificam projetos, auxiliando na distribuição dos recursos entre os pedidos. Uma vez selecionado um projeto para receber como investimento um valor que pode perfazer o total dos itens financiáveis, ocorre a contratação entre a empresa proponente, o fundo e o banco que consiste no seu agente financeiro. A etapa seguinte envolve os desembolsos do fundo para o projeto e a sua execução. Quando finalizado, ocorre tanto o retorno do investimento, na proporção em que isso é viável, quanto a prestação de contas, comprovando a aplicação dos recursos em conformidade com o orçamento e o plano de produção ou distribuição. Na ocorrência de qualquer irregularidade, sanções são aplicadas à empresa proponente, que pode chegar à suspensão da sua participação em novos editais. A figura 3.5 sintetiza o processo de captação de recursos via investimento do FSA.

Figura 3.5 - Fluxograma do investimento do Fundo Setorial do Audiovisual

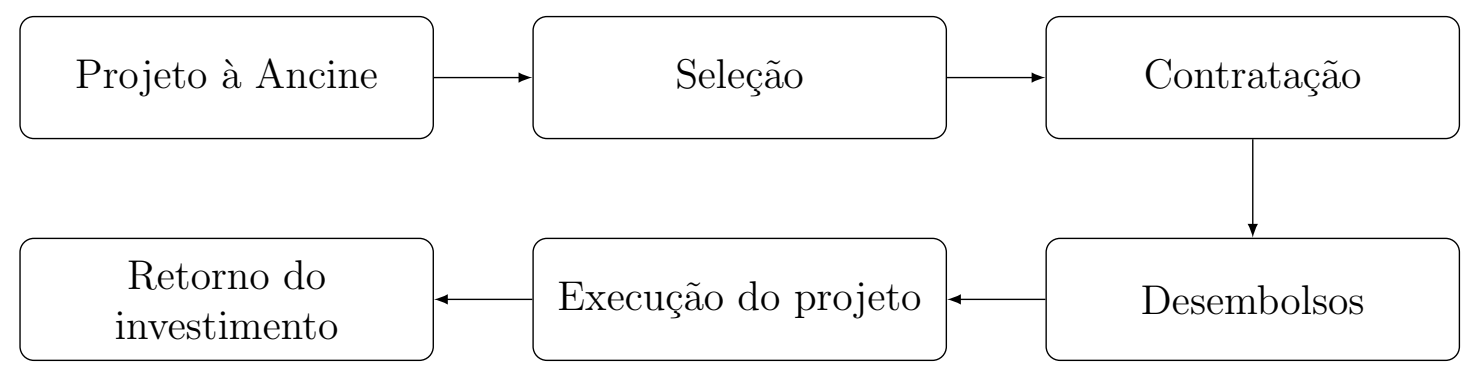

Fonte: FSA (2008). Elaboração própria.

A tabela 3.7 resume a atuação do FSA desde o início de suas operações ${ }^{27}$. As informações nela contidas foram extraídas dos Relatórios de Gestão para os anos de 20082017. Como demonstra a tabela, embora as operações do fundo iniciem em 2008, projetos

27 A análise que segue não considera dados para o Programa Cinema Perto de Você, uma vez que o seu alvo diz respeito à infraestrutura de exibição, ao invés da cadeia de produção de filmes. 
foram selecionados para investimento apenas a partir de 2009, assim como as contratações e os desembolsos ocorreram de 2011 e de 2012 em diante, respectivamente. De 2009 a 2017, foram selecionados para investimento 649 projetos de cinema (33\% do total) e 1.334 projetos de TV (67\% do total), resultando em 1.983 projetos. Quanto a desembolsos para novos projetos, totalizaram 410 para cinema (24\%) e 1.297 para TV (76\%), sendo que o valor total de desembolsos alcançou $\mathrm{R} \$ 1,23$ bilhão (a preços de 2016), onde $\mathrm{R} \$ 480$ milhões correspondem a cinema $(39 \%)$ e $\mathrm{R} \$ 749$ milhões à televisão $(61 \%) \stackrel{28}{2}$, Quanto à métrica do investimento, o FSA computa tais valores para projetos já finalizados, aos quais também se aplica a recuperação do investimento, esse definido como sendo a razão entre a receita de uma produção e o valor investido pelo fundo. A média geral de proporções de recuperação gira em torno de 13\%, tanto para cinema quanto para televisão.

A comparação entre as linhas I.i e II.i da tabela 3.7 demonstra que o foco inicial do FSA residia no setor de cinema, conforme a quantidade dos novos projetos selecionados desse setor foi sensivelmente superior que a correspondente à televisão até o ano de 2013. A partir de então, uma mudança de foco semelhante à verificada na seção 3.2 para o incentivo fiscal parece ter ocorrido também para o investimento através do FSA. Se em 2013 38\% dos novos projetos selecionados correspondiam à televisão, já em 2014 essa proporção passa a 74\%. Os números de projetos contratados (linhas I.ii e II.ii) e de desembolsos (linhas I.iii e II.iii), por estarem na sequência do processo de investimento, demonstram um mesmo comportamento de mudança de prioridades.

Os números de novos projetos selecionados também sugerem, para o ano de 2017, uma desaceleração dos investimentos em cinema (linha I.i), bem como uma contenção dos investimentos em TV (linha II.i). Igualmente, os desembolsos em TV (linha II.iv) diminuem seu ritmo de expansão em 2017. A crise fiscal pode ser uma explicação para o menor vigor de uma política que crescia fortemente, sobretudo quando considerado o setor de televisão. As linhas I.vi e II.vi sinalizam a surpreendentemente baixa eficiência dos investimentos, principalmente quando é levada em consideração a definição do fundo para a recuperação do investimento, que envolve a totalidade do valor arrecadado comercialmente pelos projetos investidos, não traduzindo adequadamente, portanto, a capacidade de devolução ao fundo dos recursos aplicados. Se as proporções médias indicadas pela tabela já são baixas, a análise da distribuição da recuperação de cada projeto é ainda

28 Considerando também o Programa Cinema Perto de Você, o total desembolsado para cinema alcança $\mathrm{R} \$ 818$ milhões, de modo que o total desembolsado pelo FSA aumenta para R $\$ 1,6$ bilhão. 
Tabela 3.7 - Investimento direto através do FSA

\begin{tabular}{|c|c|c|c|c|c|c|c|c|c|}
\hline I & Cinema & 2009 & 2010 & 2011 & 2012 & 2013 & 2014 & 2015 & 2016 \\
\hline I.i & $\mathrm{N}^{o}$ de projetos selecionados & 33 & 71 & 58 & ND & 71 & 70 & 87 & 121 \\
\hline I.ii & $\mathrm{N}^{o}$ de projetos contratados & 0 & 0 & 33 & 45 & 43 & 39 & 86 & 66 \\
\hline I.iii & $\mathrm{N}^{o}$ de novos desembolsos & 0 & 0 & 0 & 50 & 31 & 38 & 90 & 64 \\
\hline I.iv & Valor desembolsado $(\mathrm{R} \$ 1 \mathrm{mi})^{*}$ & 0 & 0 & 0 & 42,8 & 32,0 & 45,0 & 106,9 & 86,8 \\
\hline I.v & Valor investido $(\mathrm{R} \$ 1 \mathrm{mi})^{*}$ & 0 & 0 & 0 & 36,6 & 21,8 & 15,8 & 50,7 & 41,2 \\
\hline I.vi & Recuperação média (\%) & 0 & 0 & 0 & $23 \%$ & $36 \%$ & $23 \%$ & $11 \%$ & $7 \%$ \\
\hline II & TV & 2009 & 2010 & 2011 & 2012 & 2013 & 2014 & 2015 & 2016 \\
\hline II.i & $\mathrm{N}^{o}$ de projetos selecionados & 5 & 23 & 21 & ND & 43 & 204 & 368 & 453 \\
\hline II.ii & $\mathrm{N}^{o}$ de projetos contratados & 0 & 0 & 11 & 4 & 38 & 65 & 275 & 497 \\
\hline II.iii & $\mathrm{N}^{o}$ de novos desembolsos & 0 & 0 & 0 & 12 & 21 & 69 & 226 & 470 \\
\hline II.iv & Valor desembolsado $(\mathrm{R} \$ 1 \mathrm{mi})^{*}$ & 0 & 0 & 0 & 5,5 & 27,5 & 71,3 & 139,1 & 223,9 \\
\hline II.v & Valor investido $(\mathrm{R} \$ 1 \mathrm{mi})^{*}$ & 0 & 0 & 0 & 1,6 & 2,8 & 20,9 & 20,0 & 37,7 \\
\hline II.vi & Recuperação média (\%) & 0 & 0 & 0 & $15 \%$ & $14 \%$ & $15 \%$ & $14 \%$ & $11 \%$ \\
\hline
\end{tabular}

Fonte: FSA. Elaboração própria.

* A preços de 2016.

mais incisiva: para o cinema, o percentil 50 corresponde a $5,5 \%$, enquanto que os percentis 90 e 95 são de 78,6\% e 114,7\%, respectivamente. Portanto, uma parcela considerável dos projetos de cinema não tem receita suficiente para cobrir o montante investido pelo $\mathrm{FSA}^{29}$ tabela 9.10 do anexo).

O investimento direto através do Fundo Setorial do Audiovisual, portanto, movimenta valores expressivos, sobretudo para o segmento de televisão. Não obstante, os dados sugerem que o foco inicial desse instrumento da política do audiovisual residia no cinema. A partir de 2014, contudo, é que se percebe uma mudança de orientação, que foi coerente com o verificado, em um primeiro momento, para os mecanismos de incentivo fiscal. A principal constatação da análise das operações do FSA foi, ainda assim, o baixo nível dos índices de recuperação das quantias investidas.

29 Os números acima consideram projetos entre 2012 e 2017. Excluindo projetos mais recentes, que ainda podem ampliar a sua rentabilidade, entre 2012 e 2015, os números permanecem extremamente baixos: $p(50)=6,1 \%, p(90)=96,7 \%$ e $p(95)=128,3 \%$. 


\subsection{Conclusão}

A descrição da política pública exposta acima demonstrou que o panorama geral das últimas décadas se resume a três instrumentos de política principais: o incentivo fiscal, a regulação e a fiscalização e o investimento público. Progressivamente, observaram-se uma maior discricionariedade na política pública e, ao mesmo tempo, uma maior diversidade de instrumentos de incentivo. Do ponto de vista dos objetos do fomento, houve uma evolução em termos de menor interesse quanto ao setor da produção e de uma visão integrada da cadeia produtiva, suprindo-se a carência de incentivos aos setores da distribuição e da exibição, isso sobretudo após a criação do Fundo Setorial do Audiovisual. A figura|3.6, que encerra o capítulo, resume a estrutura atual da política pública de cinema no Brasil.

Os dados que ilustraram a política pública recente permitiram conclusões adicionais. Primeiramente, desperta interesse as quantias expressivas de renúncia fiscal e de investimentos do FSA. Os valores incentivados, apenas para o cinema entre 1992 e 2017, alcançam a magnitude de $\mathrm{R} \$ 6,2$ bilhões, onde $92 \%$ do total corresponde a renúncia fiscal e $8 \%$ a desembolsos do FSA. Constatou-se, adicionalmente, que o foco da política pública do audiovisual residiu no cinema, porém, houve um aumento recente na proporção do fomento à televisão, tanto através do incentivo fiscal quanto do investimento. Considerando apenas os instrumentos de renúncia fiscal, o predomínio dos pedidos enviados e dos pedidos contemplados foi do segmento de produção, do gênero de ficção e dos estados do Rio de Janeiro, de São Paulo e do Rio Grande do Sul. A distribuição dos pedidos por empresa proponente indicou a existência de poucas grandes produtoras, que tendem a mobilizar maiores volumes de recursos. Os dados sugeriram também que os períodos de mudanças institucionais, como as criações da Lei do Audiovisual e da Ancine, estiveram associados a crescimentos no incentivo fiscal. Por fim, adiantando uma métrica de resultado, surpreenderam os baixos índices de recuperação do investimento pelo FSA.

Sendo o cerne da política pública de cinema a ampliação do acesso do consumidor brasileiro ao cinema nacional, entende-se que os executores da política pretendem estimular a produção de filmes no Brasil e, igualmente, garantir a sua exibição nas salas comerciais do país, para que, então, o público possa escolher as obras nacionais, aumentando o consumo dessas em contraposição aos filmes internacionais. Dessa forma, considerando a base de dados disponível e descrita no capítulo a seguir, a eficácia da política em alcançar 
o objetivo explícito de ampliação do acesso a filmes nacionais pode ser mensurada através de variáveis de resultado como a distinção da origem de um filme exibido entre nacional e internacional, além de medidas pertinentes à escolha efetiva do consumidor, como o público e a bilheteria de cada filme.

A realização do objetivo ancilar de expandir a competitividade e a sustentabilidade da indústria de cinema nacional pode ser aferida através de uma variável que pondera a arrecadação de bilheteria de um filme pelo total de seu público, indicando a capacidade de extração de valor do consumidor pela indústria. Embora não seja tratada explicitamente como um objetivo da política pública, elevar a qualidade dos filmes nacionais pode auxiliar na escolha final do consumidor, consistindo a avaliação de cada filme pelo público, portanto, em outra variável de resultado relevante.

Mesmo que inexista diferenciação de objetivos da política de acordo com os distintos gêneros possíveis de um filme, especialmente quanto à produção de externalidades positivas em que filmes artísticos ou documentais podem implicar, a análise apresentada no capítulo a seguir, com relação à concessão de incentivo fiscal por gênero no pré e no pósAncine, sugere uma atenção especial dos gestores da política sobre um gênero de pequena disposição de consumo pelo público e, ao mesmo tempo, de grande potencial artístico e informacional, como ocorre com documentários. Desse modo, embora não seja um objetivo declarado, pode-se entender como motivação desse objetivo revelado a correção da falha de mercado em que consistem as externalidades positivas que decorrem de documentários, dada a ênfase do incentivo fiscal sobre esse gênero no pós-Ancin€ ${ }^{30}$. Adicionalmente, é importante mencionar outra possível motivação, qual seja, a geração de um impacto positivo sobre a estrutura socioeconômica da indústria do cinema, em particular, com relação a documentaristas e intelectuai, 31 .

Cabe ressaltar que a legislação do incentivo fiscal e da criação da Ancine não é clara a respeito das ineficiências que a política pública anseie corrigir. Pelos instrumentos de política criados e descritos ao longo do capítulo, depreende-se que a produção de cinema seja dificultada pela carência de mecanismos não onerosos de financiamento, de modo

30 Conforme demonstrado no próximo capítulo, a proporção de filmes com captação de incentivo fiscal que corresponde a documentários passa de $13 \%$, no pré-Ancine, para $30 \%$, no pós-Ancine.

31 Tanto a correção da citada externalidade positiva quanto o impacto positivo sobre a estrutura socioeconômica da indústria do cinema consistem em possíveis motivações para a intenção revelada, depreendidas da política pública executada. Uma vez que essas motivações são concebidas a partir da política pública observada, necessariamente representam conjecturas a respeito das reais intenções dos gestores. 
que, sem o incentivo fiscal e o investimento público, grande parte dos projetos não seriam viabilizados por conta do alto custo do capital. Com relação à distribuição e à exibição, o documento de diretrizes da criação do FSA revela uma específica preocupação de melhorar a articulação entre a produção e esses dois segmentos de atividade (FSA, 2008).

O segmento de distribuição requer, segundo o documento de diretrizes, uma diversificação das empresas atuantes orientada para a criação de empresas independentes, não comprometidas institucionalmente com a comercialização das produções de grandes estúdios. Quanto à exibição, o documento considera como ineficiência a concentração de salas de cinema na região Sudeste, sendo que no interior do país tende a predominar a exibição de obras associadas a grandes produtoras e distribuidoras.

Depreende-se que também o compromisso de exibição dos grandes complexos de cinema com as grandes empresas de distribuição motiva a política de reserva de mercado conduzida pela Ancine. De um modo geral, portanto, a integração vertical da indústria de cinema no país seria responsável por uma menor proporção de exibição de obras nacionais, tradicionalmente associadas a produtoras independentes e de menor porte, o que resultaria, então, em menores números de público e de bilheteria para os filmes brasileiros.

O apêndice B apresenta dados que retratam a estrutura dos segmentos de atividade da distribuição e da exibição. Percebe-se o predomínio de grandes distribuidoras e a concentração regional do parque exibidor no país. A não obtenção de uma base de dados que permita uma aplicação metodológica adequada resulta que os impactos da política pública sobre esses segmentos não sejam avaliados neste trabalho. Consiste, assim, em uma possibilidade de pesquisa a ser explorada futuramente.

Para a compreensão da política pública de cinema no Brasil é imprescindível estabelecer outra correspondência, dessa vez entre o objetivo principal da política e os seus instrumentos. Visando à ampliação da oferta de filmes nacionais, a Lei do Audiovisual, a Lei Rouanet e o FSA, através do Prodecine, incentivaram a produção ao prover mecanismos de captação de recursos a baixo custo em comparação ao financiamento bancário usual. Paralelamente, a ampliação da oferta contou com instrumentos voltados a melhorias na exibição e na comercialização, destacando-se novamente o Prodecine e o Programa Cinema Perto de Você. O funcionamento da Ancine igualmente contribuiu para facilitar o acesso do consumidor ao cinema nacional, na medida em que a sua regulação e a sua fiscalização instituíram formas de reserva de mercado, buscando garantir que os filmes 
nacionais estejam à disposição do público. Outras medidas, como o apoio a festivais nacionais e à participação de obras brasileiras em festivais internacionais, foram constituídas com vistas à promoção e à divulgação do produto doméstico.

Pensando nas variáveis de resultado do público, da bilheteria e do número de filmes nacionais exibidos anualmente, a política pública das últimas décadas teve instrumentos de política que configuram as seguintes formas de tratamento: valores captados com incentivo fiscal, valores captados via FSA, valores captados através de outras formas de fomento e funcionamento da Ancine com aplicação de uma legislação protetora da indústria nacional.

Figura 3.6 - Organograma da política pública de cinema

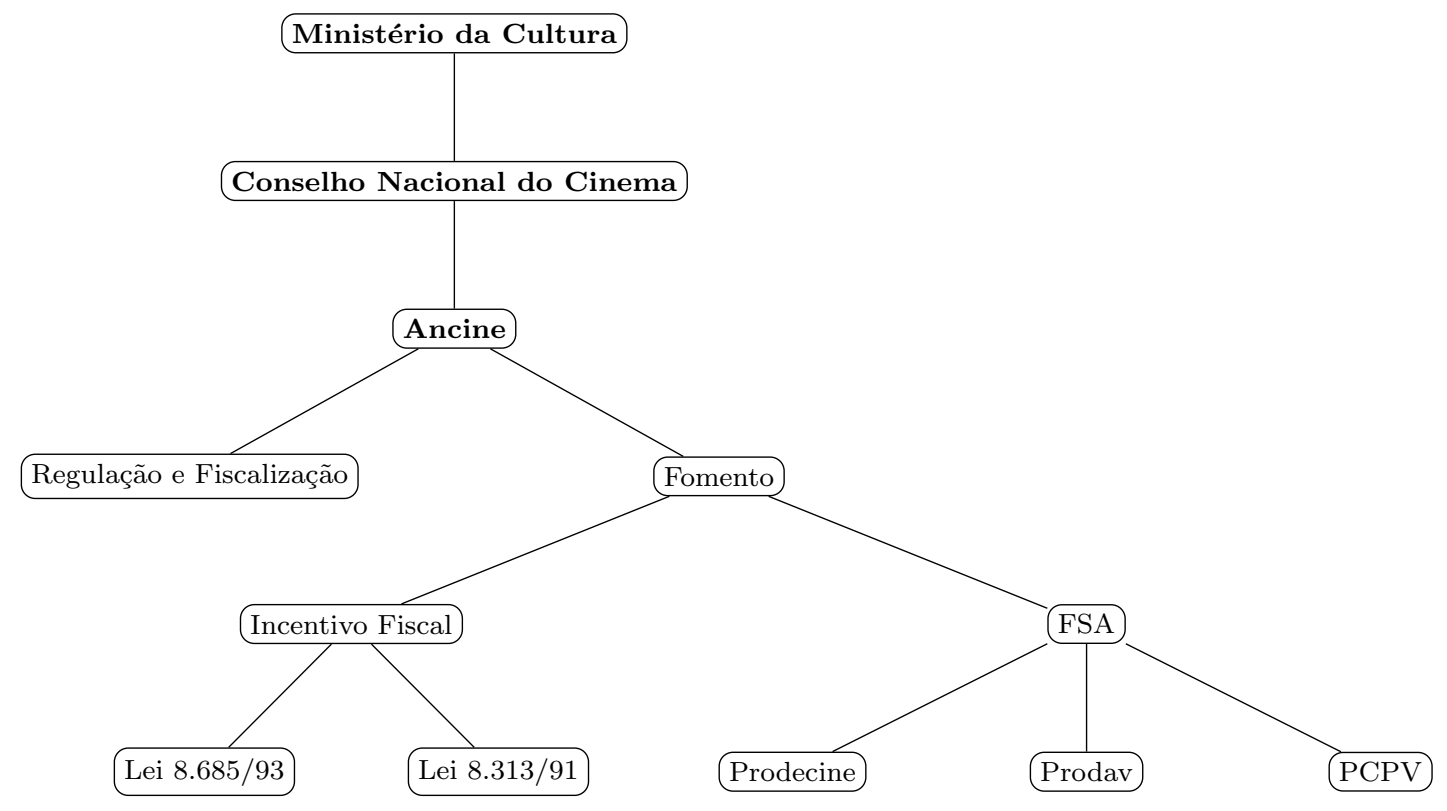

Fonte: Ancine. Elaboração própria. 



\section{Bases de dados e estatísticas descritivas}

Para além da descrição das bases de dados sobre as quais foi aplicada a metodologia para a investigação dos efeitos sobre o mercado de cinema das principais transformações institucionais das últimas décadas no setor, o presente capítulo objetiva revelar, utilizando de dados inéditos, o perfil da demanda brasileira por filmes e a estrutura da indústria nacional. Os dados que serão apresentados indicam os padrões de consumo e as suas modificações ao longo do tempo, bem como a sua associação com os instrumentos de incentivo utilizados. Desse modo, a própria exposição de dados será útil para o entendimento que se deseja alcançar quanto ao funcionamento do mercado brasileiro de cinema.

\subsection{Descrição das bases de dados}

São quatro as fontes principais dos dados utilizados ao longo do trabalho. A Ancine, por meio do Observatório Brasileiro do Cinema e do Audiovisual (OCA) e do Fundo Setorial do Audiovisual (FSA), proveu os dados de filmes nacionais exibidos no país. Para filmes internacionais, foram obtidos dados junto à empresa privada FilmeB, especializada na coleta de informações sobre o mercado cinematográfico brasileiro. Por fim, diversas informações dos filmes exibidos no país, que os caracterizam extensivamente, foram encontradas na Internet Movie Database (IMDb), website que concentra informações de inúmeros filmes exibidos em todo o mundo.

A extensão temporal da base de dados do OCA corresponde ao período de 1995 a 2016, enquanto que os dados do FSA se aplicam para os anos de 2008 a 2016. Os dados da FilmeB estão disponíveis para o intervalo de 2001 a 2016, enquanto que as informações da IMDb foram obtidas para a integralidade do período de tempo da base de dados consolidada: 1995-2016. O número de observações da base do OCA consiste em 1.394 filmes brasileiros exibidos no país entre 1995 e 2016. Os filmes nacionais que dispõem de dados de investimento do FSA são 140. O número de filmes internacionais exibidos no país entre 2001 e 2016 e registrados pela FilmeB corresponde a 3.700 títulos. Finalmente, a totalidade dos 5.094 filmes do período 1995-2016 dispõem de informações da IMDb.

A partir das quatro bases de dados acima descritas, é possível construir tanto 
variáveis de resultado, quanto variáveis explicativas referentes à política pública, além de variáveis que caracterizam os filmes exibidos no país. Os dados do OCA, por exemplo, indicam os títulos dos filmes, o seu ano de exibição, o público e a bilheteria, o valor captado com incentivo fiscal, o valor captado com outras fontes, a unidade da federação da produção da obra e o gênero (distinguido entre ficção, documentário e animação). Os dados do FSA, por sua vez, denotam os valores investidos pelo fundo em cada obra já finalizada. Para filmes internacionais, os dados da FilmeB compreendem o título do filme, o seu ano de exibição, o público e a renda de bilheteria.

Ampliando consideravelmente o conjunto de variáveis que caracterizam os filmes, a IMDb distingue o país de origem de cada filme, o gênero, o diretor, a produtora/distribuidora e a avaliação dos usuários do website. Como as combinações de países e de gêneros indicadas pela IMDb para cada filme implicariam em uma enorme lista de categorias, essas foram consolidadas em 10 categorias de origem e 18 categorias de gênero, de acordo com padrões verificados e visando a uma descrição suficientemente sintética e, ao mesmo tempo, aderente à diversidade existente nas classificações dos filmes. Então, a base de dados decorrente da consolidação das quatro bases acima citadas resulta no conjunto de variáveis principais listadas na tabela 4.1 abaixo.

Tabela 4.1 - Principais variáveis da base de dados consolidada

\begin{tabular}{|c|c|c|}
\hline Variáveis de Resultado & Variáveis Explicativas & Variáveis Explicativas \\
\hline Publico: público do filme. & $\begin{array}{l}\text { Ano: ano de exibição do } \\
\text { filme. }\end{array}$ & $\begin{array}{l}\text { Pais: país do filme, conforme } \\
\text { indicado pela IMDb. }\end{array}$ \\
\hline $\begin{array}{l}\text { Bilheteria: renda de bilheteria } \\
\text { do filme. }\end{array}$ & $\begin{array}{l}\text { Nacional: variável binária } \\
\text { indicando se o filme é ou não } \\
\text { nacional. }\end{array}$ & $\begin{array}{l}\text { Origem: origem do filme, } \\
\text { classificada de acordo com } 10 \\
\text { categorias. }\end{array}$ \\
\hline \multirow[t]{4}{*}{$\begin{array}{l}\text { Rating: avaliação do público } \\
\text { dada por usuários da IMDb. }\end{array}$} & $\begin{array}{l}\text { IncentFiscal: valor captado com } \\
\text { incentivo fiscal pelo filme. }\end{array}$ & $\begin{array}{l}\text { GeneroI MDb*: gênero do filme, } \\
\text { conforme indicado pela IMDb. }\end{array}$ \\
\hline & $\begin{array}{l}\text { InvestimentoF } S A \text { : valor } \\
\text { investido pelo fundo. }\end{array}$ & $\begin{array}{l}\text { Genero*: gênero do filme, } \\
\text { classificado de acordo com } 18 \\
\text { categorias. }\end{array}$ \\
\hline & $\begin{array}{l}\text { OutrasFontes: valor captado com } \\
\text { outras fontes. }\end{array}$ & Diretor: diretor do filme. \\
\hline & $\begin{array}{l}U F \text { : origem regional do filme, } \\
\text { caso esse seja nacional. }\end{array}$ & Produtora: produtora do filme. \\
\hline
\end{tabular}

Fonte: elaboração própria.

Variáveis para o filme $i$ exibido no ano $t$.

* Foi realizada uma agregação das categorias tais como dispostas pelo site da IMDb, diminuindo-se o número de categorias excludentes de 875 para 18 . 


\subsection{Estatísticas dos filmes exibidos no país entre 2001 e 2016}

Nas próximas subseções, serão expostos dados que auxiliam na compreensão da evolução da indústria e do mercado brasileiros de cinema. Mais do que apontar padrões que a metodologia do trabalho buscará explorar, a exposição que segue leva a importantes conclusões a respeito do perfil da demanda brasileira por filmes e quanto à estrutura da indústria nacional de cinema. Inicialmente, serão analisados dados de exibição no país para o período que se estende de 2001 a 2016, para produções nacionais e internacionais.

A primeira estatística, apresentada na figura 4.1 , ilustra a evolução e o panorama geral do mercado brasileiro de cinema. Devido à elevada proporção média de filmes internacionais com relação ao total (74\%), o comportamento do total de filmes exibidos anualmente segue o comportamento de exibição dessa categoria de filmes. Ainda assim, notam-se dois momentos de aceleração no crescimento anual do número de filmes nacionais exibidos: o pós-2004, subsequente ao início do funcionamento da Ancine, e o pós-2012, subsequente ao início das operações do FSA. De um modo geral, a evolução da exibição de ambas as categorias de filmes revela que a proporção de obras nacionais exibidas cresceu com o tempo. A intenção da política pública de expandir a oferta de filmes nacionais foi, sob esse ponto de vista, exitosa.

Analisando, na figura $4.2(\mathrm{a})$, a evolução do público, percebe-se um comportamento semelhante entre o público médio de filmes nacionais e o público médio de filmes internacionais. Por sua vez, a figura 4.2(b) revela que, a partir de 2008, houve um crescimento no nível do público nacional como proporção do público total, embora tal elevação seja mais modesta que a verificada no número de filmes nacionais exibidos. Desse modo, o êxito verificado no lançamento de produções brasileiras não se aplicou da mesma forma à variável de resultado do público, o que se constata, ao menos, a partir desses números gerais.

Alternativamente, a tabela 4.2 , de diferenças de média entre os filmes nacionais e internacionais e entre os períodos posterior e anterior ao funcionamento da Ancine, apresenta diferenças negativas entre os públicos médios de produções nacionais e de internacionais em ambos os períodos de tempo selecionados (-299.571 e -223.890), decorrentes da predileção do consumidor brasileiro por filmes estrangeiros. Há também uma queda no pós-Ancine para ambas as classificações de origem (-297.687 e -222.006), em virtude da menor predisposição geral ao consumo de cinema por fatores como a pirataria, o streaming 
Figura 4.1 - Filmes exibidos por ano

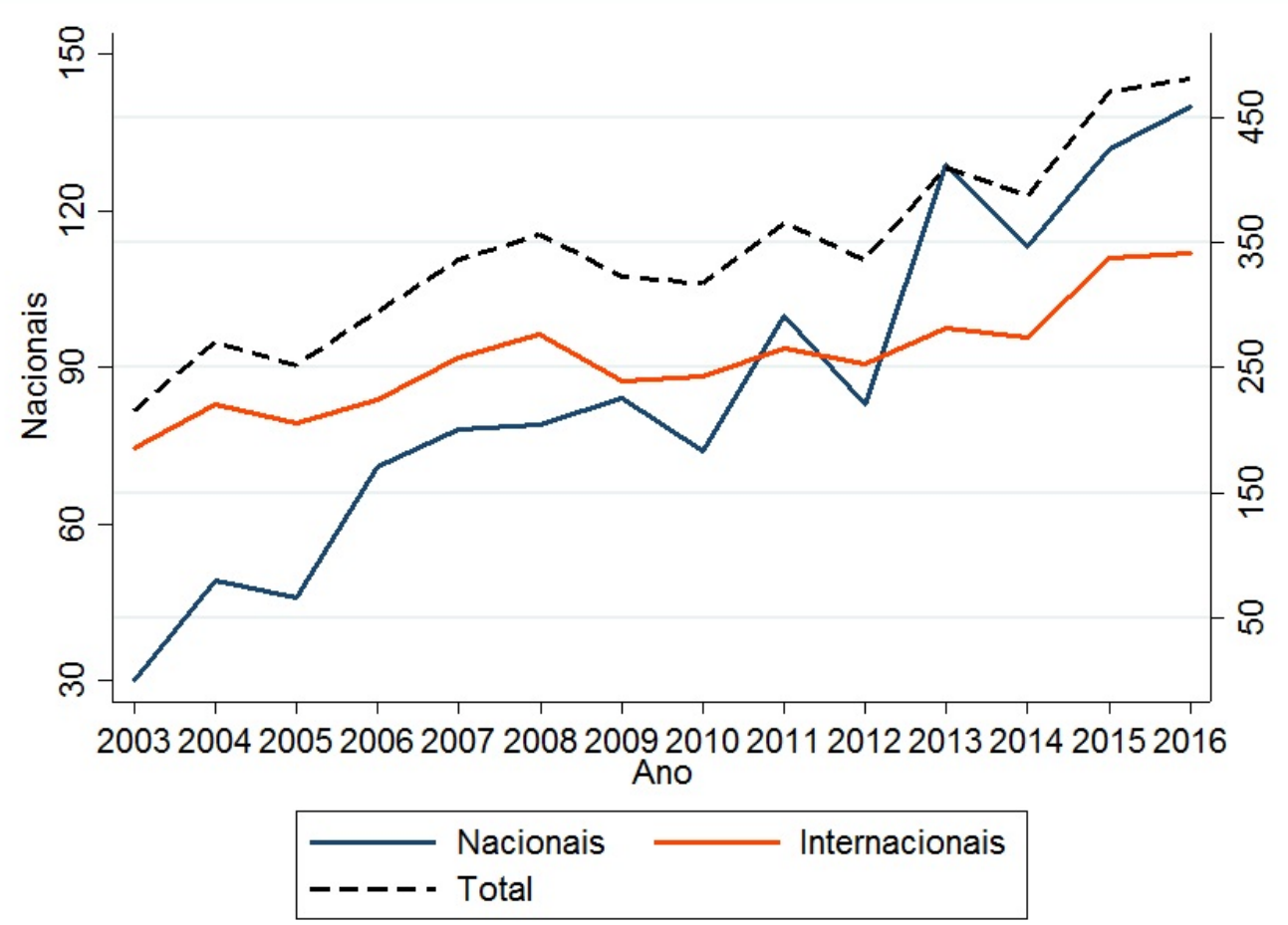

Fonte: Ancine, FilmeB. Elaboração própria.

Figura 4.2 - Público médio (milhares de pessoas) e proporção nacional do público total por ano
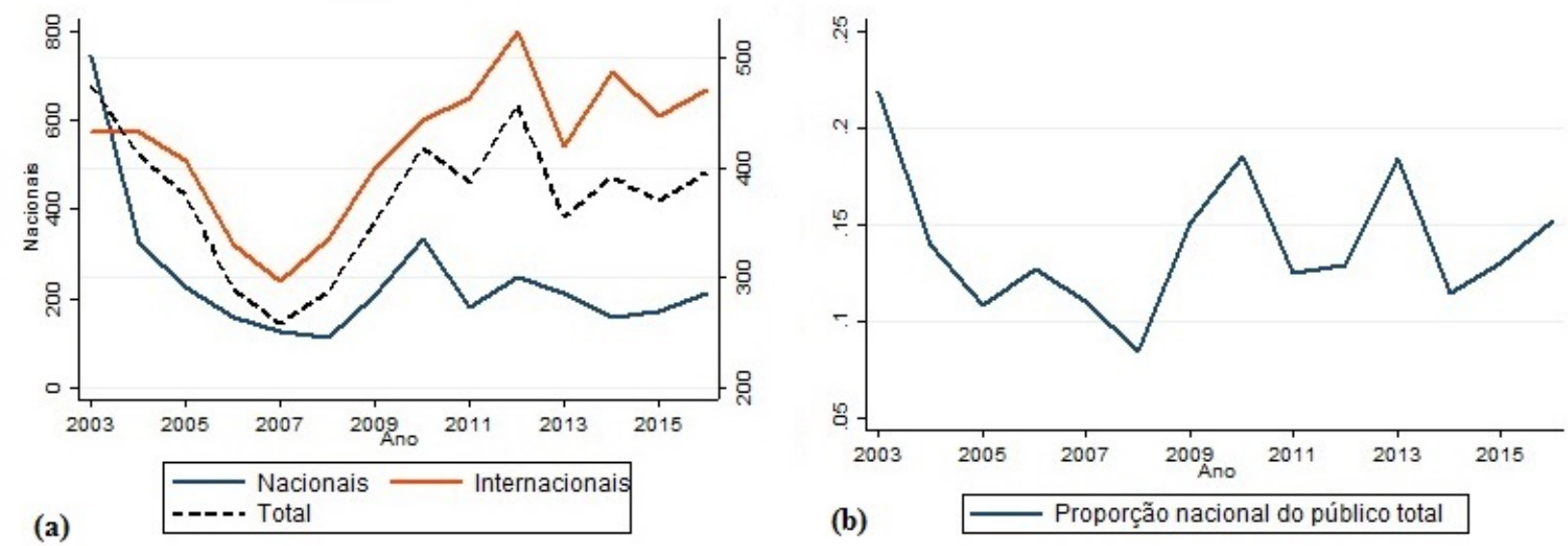

Fonte: Ancine, FilmeB. Elaboração própria.

e outras opções de entretenimento. A diferença das diferenças de média (75.681) denota, contudo, que a queda no tempo do público médio de filmes nacionais foi menor do que a verificada para filmes internacionais. Assim, mesmo com números bastante agregativos, fica posto que, no período de funcionamento da Ancine, o público de filmes nacionais va- 
riou positivamente frente ao público de filmes internacionai: $\Upsilon^{1}$ o que é favorável à intenção da política de ampliação do acesso ao cinema naciona $\bigsqcup^{2}$

Tabela 4.2 - Diferenças de médias

\begin{tabular}{lccc}
\hline Público & Internacionais & Nacionais & Diferença \\
\hline Pré-Ancine & 719.910 & 420.339 & -299.571 \\
Pós-Ancine & 422.223 & 198.333 & -223.890 \\
\hline Diferença & -297.687 & -222.006 & 75.681 \\
\hline
\end{tabular}

Fonte: Ancine, FilmeB. Elaboração própria.

Iniciando a caracterização do mercado brasileiro de cinema, a tabela 4.3 indica as categorias de origem criadas a partir das classificações por país dos filmes registrados na IMDb. As dez categorias criadas buscam captar as diferenças de produtos de regiões definidas, a um só tempo, de modo a resumir as origens possíveis e representar a diversidade existente. Destaca-se que, da categoria EUA/Canadá, 12\% envolve o Canadá em sua produção, logo, $88 \%$ se restringe aos EUA (além de outros países em regime de coprodução). O Canadá compartilha a categoria dos EUA por razões de similaridade cultural e linguística e, principalmente, por conta de a maioria dos filmes que envolvem, em sua produção, o Canadá estarem também associados aos EUA ${ }^{3}$. A distinção entre Europa Ocidental, Restante da Europa e Países Ibéricos, por sua vez, reflete distinções culturais e linguísticas. Por fim, cabe mencionar que a classificação dentro das dez categorias de origem levou em consideração a listagem dos países de um filme e, caso envolvessem países de categorias diversas dentre as criadas, foi verificada a predominância de origem do elenco do filme.

São notórios o predomínio da exibição de filmes dos EUA/Canadá (43,1\% do total) e a média de público muito elevada para os filmes dessa região. Consequentemente, o seu público agregado alcança o patamar considerável de quase 1,5 bilhão de pessoas. Na sequência, há destaque para os filmes brasileiros, em termos de exibição e de público;

1 Testes de hipóteses de diferenças de média demonstraram que: i) público médio de filmes nacionais inferior estatisticamente ao de internacionais; ii) queda de público significativa a $1 \%$ no pós-Ancine; iii) queda de público significativa a $1 \%$ no pós-Ancine para filmes internacionais; iv) queda de público não significativa a $5 \%$ no pós-Ancine para filmes nacionais.

2 A conclusão se mantém mesmo excluídos outliers. Desconsiderando os cinco maiores públicos anuais, a diferença das diferenças de médias de público corresponde a 90.139 pessoas.

3 De 262 filmes com o Canadá dentre os países listados pela IMDb, 197 (75\%) deles dispõem dos EUA. 
inclusive, o público recorde corresponde a um filme brasileirq4. Quanto às demais categorias internacionais, a Europa Ocidental é a origem mais relevante, também em termos de exibição e de público médio. Chama a atenção o pequeno público médio dos filmes da América Latina, dos quais se espera uma maior semelhança com as produções brasileiras, essas que apresentam um público médio mais de cinco vezes superior. Finalmente, a diferença entre os públicos médios dos EUA/Canadá e da Europa Ocidental com relação a categorias como o Sudeste Asiático, o Restante da Europa e a África demonstra a importância, para o consumo de cinema pelo brasileiro, da origem dos filmes ser culturalmente convencional.

Tabela 4.3 - Estatísticas de público por origem

\begin{tabular}{lcccc}
\hline Origem & Filmes & $\begin{array}{c}\text { Média } \\
\text { (milhares) }\end{array}$ & $\begin{array}{c}\text { Máximo } \\
\text { (milhões) }\end{array}$ & $\begin{array}{c}\text { Agregado } \\
\text { (milhões) }\end{array}$ \\
\hline EUA/Canadá & $2.130(43,1 \%)$ & 682,3 & 10,9 & 1.450 \\
Europa Ocidental & $967(19,6 \%)$ & 163,8 & 5,6 & 158 \\
Oceania & $21(0,4 \%)$ & 106,6 & 0,7 & 2,2 \\
Brasil & $1.243(25,1 \%)$ & $100,5^{*}$ & 11,3 & 266 \\
Sudeste Asiático & $129(2,6 \%)$ & 95,2 & 1,6 & 12 \\
Países Ibéricos & $75(1,5 \%)$ & 89,0 & 1,7 & 6,7 \\
África & $20(0,4 \%)$ & 61,3 & 0,5 & 1,2 \\
AL & $160(3,2 \%)$ & 38,3 & 0,9 & 6,1 \\
Restante da Europa & $142(2,9 \%)$ & 30,6 & 0,7 & 4,3 \\
Oriente Médio & $56(1,1 \%)$ & 16,9 & 0,2 & 0,9 \\
\hline Total & 4.943 & 386,8 & 11,3 & 1.910 \\
\hline
\end{tabular}

Fonte: Ancine, FilmeB, IMDb. Elaboração própria.

* Média brasileira desconsiderando os três maiores públicos por ano.

A distinção das proporções de filmes exibidos por categoria de origem no pré e no pós-Ancine, exposta na figura|4.3, demonstra que, com o funcionamento da agência, houve uma forte diversificação na exibição de filmes estrangeiros, destacando-se o crescimento da proporção de filmes da Europa Ocidental e da América Latina. Cresce também, embora modestamente, a participação dos filmes nacionais no total exibido. Essa diversificação, como se observa, deu-se às custas de um menor peso para a exibição de filmes norteamericanos. Interessa como, justamente, a diversificação das obras estrangeiras exibidas no país consistia em um dos objetivos da Ancine, conforme se encontra no artigo 6, item

4 Seja "Os Dez Mandamentos - O Filme" (2016), sobre o qual se estabeleceu uma polêmica quanto à compra artificial de ingressos pelos produtores do filme, seja "Tropa de Elite 2"(2010). Ambos alcançaram a marca de mais de 11 milhões de pessoas. 
VIII da MP 2.228-1 (BRASIL, 2001).

Figura 4.3 - Proporções de filmes por origem

Pré-Ancine
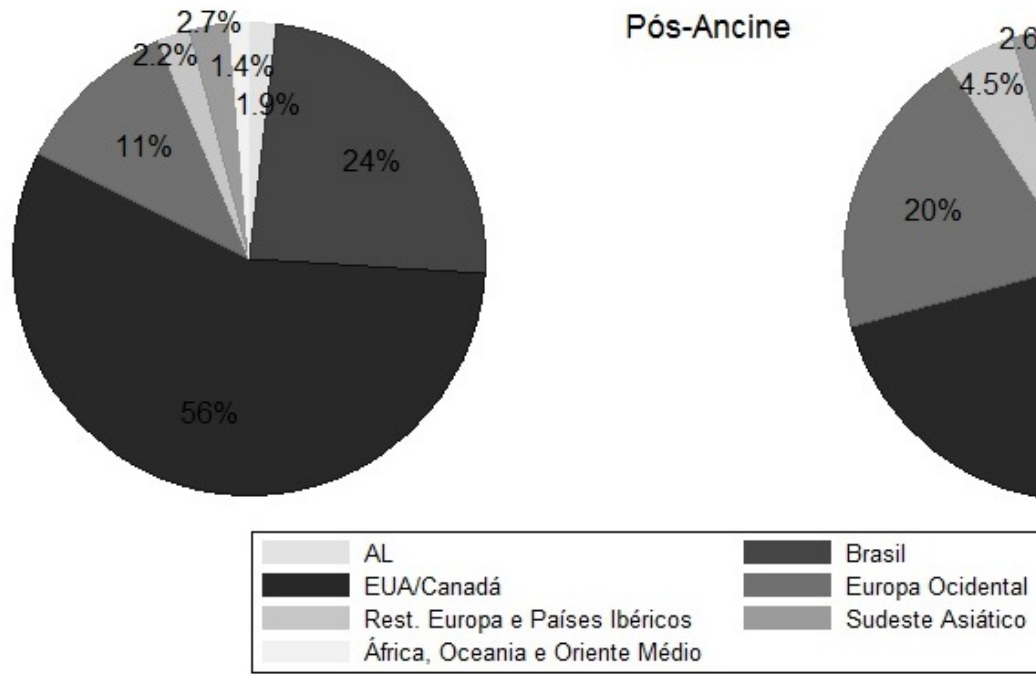

Fonte: Ancine, FilmeB, IMDb. Elaboração própria.
Pós-Ancine

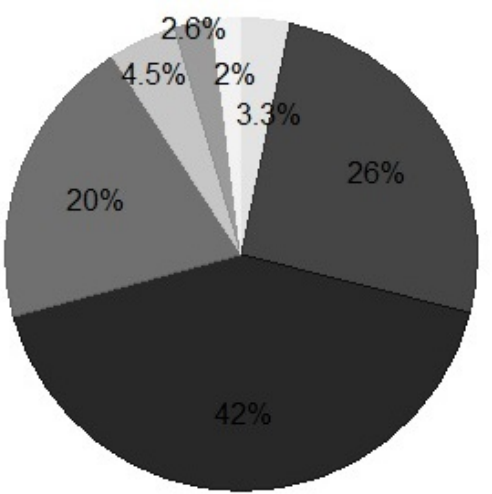

Europa Ocidental

Sudeste Asiático

Além da classificação da origem dos filmes de acordo com as dez categorias criadas, a influência de países específicos sobre o desempenho das produções auxilia na compreensão dos padrões de consumo. A influência de países específicos é definida pela presença de um dado país na classificação apresentada pela IMDb, independentemente da categoria de origem definida para um filme. Por exemplo, a tabela|10.1 do anexo demonstra que os EUA expandem consideravelmente a média de público de diversas categorias de origem. Para a Europa Ocidental e para o Sudeste Asiático, o público médio é superior em 260\% com a participação dos EUA nas produções, enquanto que para o Oriente Médio e África a elevação alcança 278\%. Um efeito semelhante se verifica na América Latina com relação a coproduções envolvendo a Argentina e, sobretudo, o Brasil (médias de público superiores em 34\% e 120\%, respectivamente). Na Europa Ocidental, observa-se como o país mais importante na atração de público para essa categoria o Reino Unido, com público médio mais de duas vezes superior ao verificado para toda a região. Portanto, conclui-se pela relevância do idioma e da cultura predominantes internacionalmente na predileção dos consumidores de cinema brasileiros.

A tabela 4.4 lista as 18 categorias criadas para a classificação dos filmes quanto ao gênero, a partir do registro pela IMDb. Novamente, buscou-se uma suficiente agregação, sem prejudicar a diversidade de tipos de filmes. Assim, distinguiu-se, por exemplo, o 
Tabela 4.4 - Estatísticas de público por gênero

\begin{tabular}{lccccc}
\hline Genero & Filmes & $\begin{array}{c}\text { Média } \\
\text { (milhares) }\end{array}$ & $\begin{array}{c}\text { Máximo } \\
\text { (milhões) }\end{array}$ & $\begin{array}{c}\text { Agregado } \\
\text { (milhões) }\end{array}$ & $\begin{array}{c}\text { Proporção } \\
\text { Brasil (\%) }\end{array}$ \\
\hline Ação e Aventura & $226(4,6 \%)$ & 1.846 & 10,9 & $417 \mathrm{mi}$ & 2,2 \\
Aventura & $132(2,7 \%)$ & 1.299 & 11,3 & $171 \mathrm{mi}$ & 21,2 \\
Animação & $290(5,9 \%)$ & 1.183 & 9,3 & $343 \mathrm{mi}$ & 7,2 \\
Comédia e Aventura & $100(2 \%)$ & 701,6 & 6,1 & $7,0 \mathrm{mi}$ & 8 \\
Ação e Terror & $38(0,8 \%)$ & 596,9 & 3,7 & $22,7 \mathrm{mi}$ & 5,3 \\
Ação & $158(3,2 \%)$ & 558,4 & 11,1 & $88,2 \mathrm{mi}$ & 19,0 \\
Comédia & $306(6,2 \%)$ & 512,6 & 5,8 & $157 \mathrm{mi}$ & 36,6 \\
Comédia e Romance & $204(4,1 \%)$ & 426,7 & 4,8 & $87,1 \mathrm{mi}$ & 17,6 \\
Ação e Suspense & $3376,8 \%)$ & 372,9 & 5,1 & $126 \mathrm{mi}$ & 4,7 \\
Terror & $218(4,4 \%)$ & 359,8 & 3,7 & $78,4 \mathrm{mi}$ & 6,0 \\
Comédia e Ação & $147(3 \%)$ & 320,4 & 3,2 & $47,1 \mathrm{mi}$ & 7,5 \\
Suspense & $230(4,7 \%)$ & 222,3 & 4,7 & $51,1 \mathrm{mi}$ & 16,5 \\
Romance & $17(0,3 \%)$ & 195,5 & 1,3 & 3,3 & 52,9 \\
Comédia, Drama e & $219(4,4 \%)$ & 176,0 & 2,3 & $38,6 \mathrm{mi}$ & 18,3 \\
Romance & $347(7 \%)$ & 166,0 & 6,7 & $57,6 \mathrm{mi}$ & 11,0 \\
Drama e Romance & $1.062(21,5 \%)$ & 106,4 & 6,9 & $113 \mathrm{mi}$ & 36,3 \\
Drama & $325(6,6 \%)$ & 96,6 & 5,5 & $31,4 \mathrm{mi}$ & 12,9 \\
Comédia e Drama & $587(11,9 \%)$ & 15,5 & 0,7 & 9,1 & 75,8 \\
Documentário & 4.943 & 386,8 & 11,3 & 1.910 & 25,1 \\
\hline Total & & &
\end{tabular}

Fonte: Ancine, FilmeB, IMDb. Elaboração própria.

gênero da comédia do gênero da comédia e romance, na medida em que ambos compartilhem de um conteúdo e de uma linguagem típicas da comédia, porém, conforme o segundo disponha de uma interseção com o gênero do romance. O registro de gênero pela IMDb é mais padronizado do que o correspondente à origem, sendo que o único procedimento de classificação envolveu a separação dos gêneros, de acordo com as 18 categorias criadas, de seus qualificativos, que se referem à temática de cada obra.

Os gêneros com maiores números de exibição consistem no Drama, no Documentário e no Drama e Romance. Justamente, tratam-se de categorias com as mais baixas médias de público. O gênero do documentário, inclusive, apresenta uma incrivelmente baixa média de público, sendo o seu público máximo inferior à média dos três gêneros de maior valor médio e o seu público agregado inferior ao público máximo de animação. Antecipa-se que, dos 587 documentários, uma grande proporção desses (76\%) é brasileira, ao mesmo tempo em que uma parcela considerável dos filmes nacionais com incentivo fiscal são desse gênero. Na outra ponta, os gêneros de aventura (Ação e Aventura e Aventura) dispõem 
dos maiores públicos médios e do maior público agregado (587 milhões de pessoas), havendo relevância destacada também para os gêneros de comédia e para os gêneros de ação. Por fim, a Animação apresenta números expressivos de exibição (sexta maior), média de público (terceira maior) e público agregado (segundo maior).

Os qualificativos de gênero, a que se fez referência anteriormente, representam temáticas recorrentes que se somam aos 18 gêneros definidos acima na classificação disponibilizada pela IMDb. Observa-se a importância de temáticas específicas para a composição da média de público de alguns gêneros, como a história e a guerra para o gênero de drama: com esses qualificativos, o público médio do gênero é superior em 100\% e 49\%, respectivamente, conforme indicado na tabela 10.2 do anexo. Da mesma forma, a ficção científica e a fantasia implicam, para os gêneros de aventura, em públicos médios superiores em $47 \%$ e 40\%, respectivamente. Com relação aos documentários, para os quais o público esperado é reduzido, a temática musical implica em um público médio $250 \%$ superior ao correspondente ao gênero como um todo.

Outra análise pertinente envolve a interação entre origens e gêneros, tais como definidos acima. Da tabela 10.3 do anexo, nota-se que o consumidor de filmes nacionais tem manifesta predileção pelo gênero da comédia (público médio mais de quatro vezes superior à média nacional), ao mesmo tempo em que o consumidor desse gênero prioriza as produções brasileiras (média quase duas vezes superior à do gênero), algo raro de ser verificado. Adicionalmente, embora a indústria nacional se dedique com intensidade ao gênero de documentário, mesmo o consumidor desse tipo de obra não tem particular interesse na produção doméstica: o público médio de documentários brasileiros é $36 \%$ inferior à média do gênero como um todo. Quanto à principal categoria de origem, o público de filmes dos EUA/Canadá se volta mais aos gêneros de aventura, em termos proporcionais e absolutos, da mesma forma que o consumidor típico desse gênero tem predileção por obras norte-americanas. Mais do que isso, nota-se que $70 \%$ da produção desse gênero tem por origem os EUA ou o Canadá.

Observando, principalmente, as variáveis de categorias de origem e gênero, é natural conceber um "filme convencional" como sendo aquele cuja origem seja mais facilmente assimilável pelo consumidor, tendo em vista o histórico de exibição de filmes que forjou suas predileções quanto ao cinema, da mesma forma que alguns gêneros têm aceitação imediata pelo público, independentemente da qualidade ou da inovação da obra. Um 
filme convencional é, por definição, um filme de que se espera um público elevado, por ser um produto cuja absorção requer pouca disposição ao novo e ao diferente pelo consumidor. Tendo isso em mente, foi criado um "índice de convencionalidade", inspirado por Collins, Scorcu e Zanola (2009), embora com uma motivação e com uma composição distintas. Esse índice, que varia continuamente entre 0 e 1, foi definido em função crescente de atributos que fazem de um filme uma obra mais convencional, isto é, de maior divulgação e de imediata aceitação pelo público. Assim sendo, seguindo o procedimento descrito no apêndice C, foram atribuídos pontos aos filmes para cada uma das seguintes categorias: origem, gênero, participação dos EUA na produção, associação com grande produtora/distribuidora e diretor vencedor de Oscar.

A influência de origens e de gêneros distintos sobre o público médio já foi analisada, bem como a participação dos EUA nas produções. O efeito da associação com grandes produtoras/distribuidoras será exposto na sequência; quanto à influência de um diretor vencedor de Oscar, encontra-se que a média de público para filmes dirigidos por um cineasta que recebeu a premiação, por um outro trabalho, em um ano anterior à exibição do filme é de 669.583 pessoas, quase o dobro da média de público indiscriminada. Calculado o índice, esse apresentou média de 0,4069 e desvio padrão de 0,1926. Conforme a figura 4.4. a única origem com índice médio superior à média geral foi os EUA/Canadá, refletindo ser essa origem a referência em termos de filmes convencionais. Percebe-se também que os filmes nacionais, embora abaixo das produções norte-americanas, encontram-se no mesmo patamar de outras origens internacionais, como a Europa Ocidental, a Oceania e o Sudeste Asiático.

Visando ilustrar a associação entre a convencionalidade de um filme e a sua renda de bilheteria, foram realizadas regressões, cujos resultados estão expostos na tabela 10.4 do anexo. A especificação mais completa indica que uma produção um ponto percentual mais convencional está associada a uma bilheteria média superior em 6 pontos percentuais. Uma segunda classe de regressões tem por variáveis explicativas principais dummies indicando a que quartil de convencionalidade um filme pertence. A especificação mais completa sugere, por exemplo, uma média de renda de bilheteria 200\% superior para um filme do quartil mais convencional em comparação ao primeiro quartil.

Conhecer os principais participantes do mercado brasileiro de cinema é importante para a sua caracterização. A tabela 4.5 demonstra que produtoras associadas à animação 
Figura 4.4 - Público médio e índice de convencionalidade médio por origem

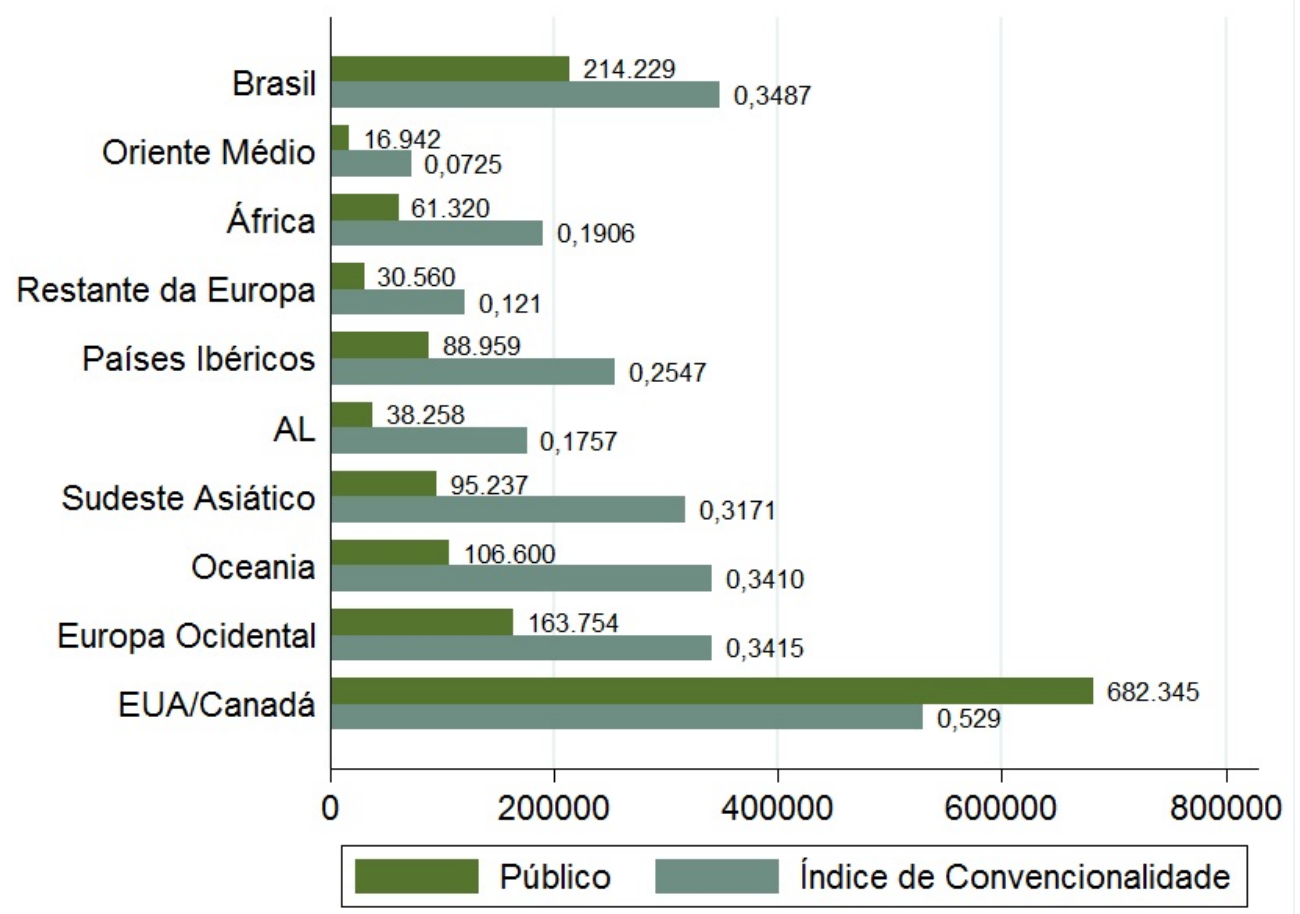

Fonte: Ancine, FilmeB, IMDb. Elaboração própria.

(Walt Disney e DreamWorks) têm médias de público destacadas, bem como a Marvel, cuja produção é essencialmente de filmes de aventura com temática de ficção científica e de fantasia; reflete-se, então, as médias de público elevadas desses gêneros (com os citados qualificativos), estando listados os principais agentes desse rentável segmento do mercado. Desperta a atenção a média de público da Globo Filmes, produtora e distribuidora nacional que tem acesso a elencos de amplo reconhecimento pelo público brasileiro, um fator relevante para o sucesso de uma produção nacional. Com relação às produtoras tradicionais, essas apresentam, em geral, médias de público inferiores, porém, o público acumulado é considerável, especialmente por conta do grande número de filmes exibidos.

Uma última variável a ser explorada para o conjunto de filmes nacionais e internacionais (a partir do ano de 2001) corresponde à avaliação pelo público das obras exibidas no país. A IMDb dispõe de um espaço para que seus usuários avaliem, com notas de 0 a 10, os filmes por eles assistidos. Embora apresente limitações, como a sensibilidade das notas de filmes com poucas avaliações e como o fato de ser composto por um público mais abrangente que o brasileiro, o rating da IMDb proporciona uma medida da quali- 
Tabela 4.5 - Estatísticas de público por produtora/distribuidora

\begin{tabular}{lcccc}
\hline Produtora/Distribuidora & Filmes & $\begin{array}{c}\text { Média } \\
\text { (milhares) }\end{array}$ & $\begin{array}{c}\text { Máximo } \\
\text { (milhões) }\end{array}$ & $\begin{array}{c}\text { Agregado } \\
\text { (milhões) }\end{array}$ \\
\hline Marvel & $39(0,8 \%)$ & 3.934 & 10,9 & 153 \\
Columbia Pictures & $328(6,6 \%)$ & 1.180 & 9,6 & 387 \\
Walt Disney & $328(6,6 \%)$ & 1.113 & 10,9 & 365 \\
DreamWorks & $121(2,4 \%)$ & 1.097 & 7,4 & 133 \\
Globo Filmes & $185(3,7 \%)$ & 1.026 & 11,1 & 190 \\
Fox & $429(8,7 \%)$ & 1.018 & 9,3 & 437 \\
Warner & $745(15,1 \%)$ & 878,8 & 9,3 & 655 \\
Universal Pictures & $616(12,5 \%)$ & 707,9 & 9,9 & 436 \\
Demais produtoras & $3.022(61,1 \%)$ & 99,5 & 11,3 & 301 \\
\hline Total & 4.943 & 386,8 & 11,3 & 1.910 \\
\hline
\end{tabular}

Fonte: Ancine, FilmeB, IMDb. Elaboração própria.

dade de cada produção, tal como entendida pelos próprios consumidores. A figura 4.5 ilustra a distribuição das avaliações para cinco origens, tendo as densidades de Kernel formatos similares ao da distribuição normal, isto é, há concentrações em torno da média e desvios relativamente simétricos a partir do valor médio. Depreende-se uma média geral em torno de 6,5 pontos, tendo em vista a altura das densidades nesse valor para filmes norte-americanos, brasileiros e europeus, categorias com as maiores quantidades de filmes exibidos no país.

Partindo das classificações de origem e de gênero, as origens com rating médio superior à média geral $(6,5)$ são: América Latina $(6,71)$, Europa Ocidental $(6,67)$, Oriente Médio $(7,14)$, Países Ibéricos $(6,74)$, Restante da Europa $(7,05)$, Sudeste Asiático $(7,04)$ e África $(6,92)$. Portanto, as origens com avaliações elevadas consistem, justamente, em categorias de relativamente pouca exibição no país e de baixo público médio. Quanto aos gêneros, aqueles que apresentam rating médio superior à média geral $(6,5)$ são o documentário $(7,29)$ e o drama $(6,68)$. Novamente, os gêneros com avaliações elevadas consistem em categorias com baixa média de público, embora disponham, nesse caso, de grande exibição no país.

Resumindo as principais constatações desta seção, quanto à evolução e ao panorama geral do mercado, os filmes internacionais exibidos representam um número bastante superior ao de nacionais e também o público médio de produções estrangeiras supera o de produções domésticas. Ainda assim, houve um crescimento mais intenso do lançamento de filmes nacionais comparativamente a filmes internacionais, o que se trata de uma 
Figura 4.5 - Distribuição das avaliações do público dadas por usuários do IMDb

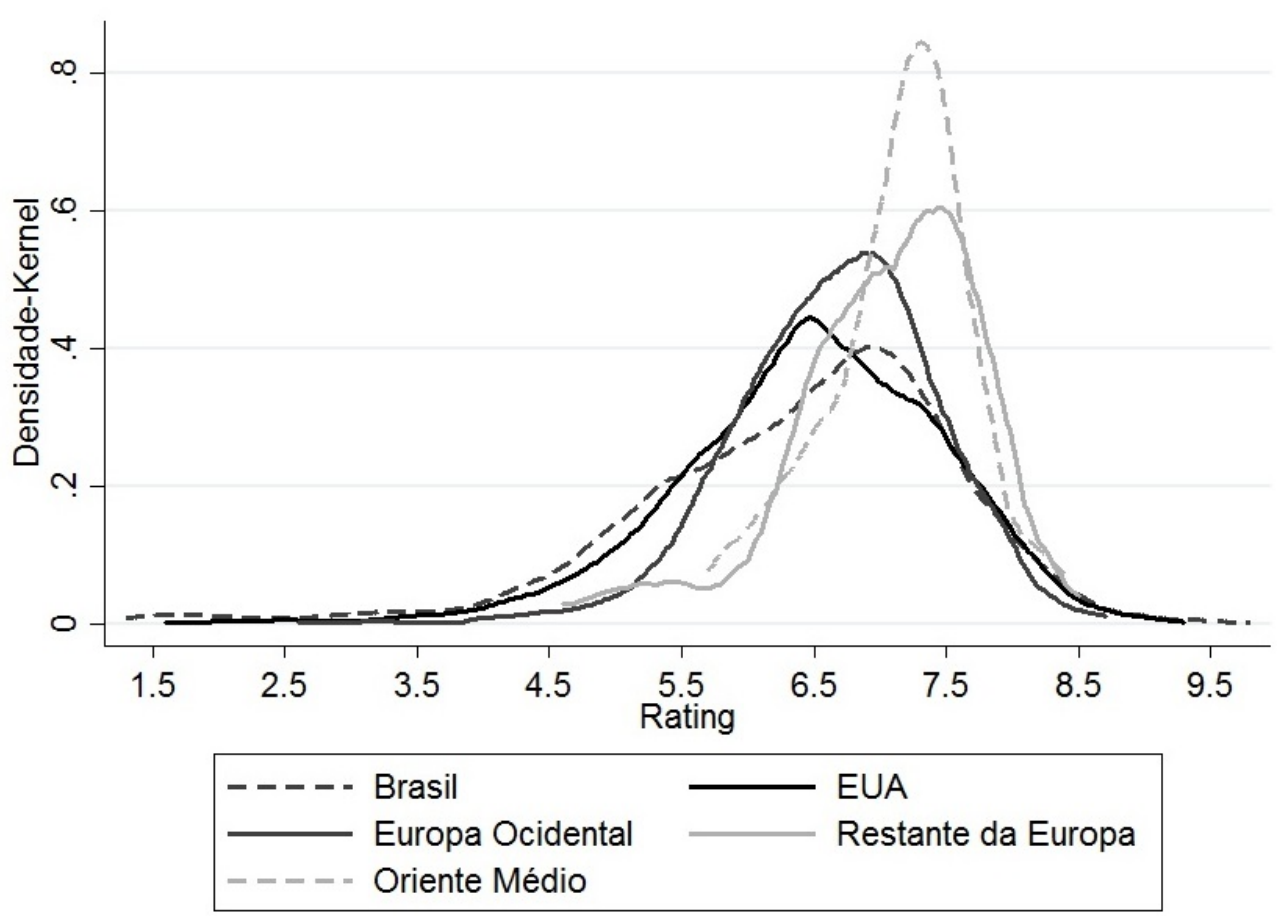

Fonte: IMDb. Elaboração própria.

evidência relevante tendo-se em mente o objetivo da política pública de que o acesso a filmes nacionais seja ampliado. A variação do público médio de filmes nacionais, contudo, foi mais modesta. Mais significativa é a comparação de médias que demonstra que, no pós-Ancine, a queda no público médio foi menor para filmes nacionais do que para internacionais, revelando que os primeiros tiveram seu público variando positivamente frente ao dos segundos.

Quanto ao perfil da demanda brasileira por cinema, há um predomínio de exibição e de público para filmes norte-americanos, destacando-se os filmes brasileiros como a segunda categoria de origem mais importante. A grande discrepância entre os filmes internacionais quando comparados os EUA/Canadá e a Europa Ocidental com as diversas outras categorias aponta para a importância da convencionalidade das obras, em termos de idioma, elenco e ambientação dos filmes, para o consumo de cinema pelo brasileiro. A diversificação da exibição em termos de origem no pós-Ancine corresponde a uma constatação relevante tendo-se em mente o objetivo da política pública de diversificar as obras estrangeiras exibidas no país, ainda que a mesma diversificação não se aplique, contudo, aos números de público.

Em termos de gênero, o documentário e o drama dispõem de grandes quantidades de 
títulos exibidos, porém, seu apelo junto ao público consumidor é pequeno. Há predileção, no Brasil, pelos gêneros de aventura e pela animação. Além disso, ficou evidenciado que o consumidor de filmes nacionais se volta para o gênero da comédia, e que o consumidor dessa classe de filmes valoriza particularmente as comédias nacionais. Paralelamente, a despeito da grande proporção de documentários nacionais exibidos, o público médio desses filmes é inferior mesmo à média de documentários em geral. Por outro lado, as categorias de origem e de gênero mais rentáveis estão associadas: produções de aventura norte-americanas têm as mais elevadas médias de público.

Os EUA/Canadá representam uma origem convencional e, mais do que isso, também seus produtos são, de um modo geral, bastante convencionais, conforme o índice calculado demonstra, ao considerar outras características conjuntamente à origem. Inclusive, quanto maior a convencionalidade, maior é a rentabilidade esperada de um filme, havendo uma grande elasticidade nessa relação. Outra evidência confirma que as grandes produtoras acumulam uma considerável quantidade de público, sobretudo as mais tradicionais, enquanto que as maiores médias de público são de produtoras associadas a gêneros mais atrativos, como a animação (Walt Disney, DreamWorks) e a aventura com fantasia e ficção científica (Marvel). Por fim, as origens e os gêneros com as maiores médias de avaliação pelos usuários da IMDb dispõem de um baixo apelo do público brasileiro.

\subsection{Estatísticas dos filmes nacionais exibidos no país}

Os dados que serão apresentados a seguir caracterizam a indústria e a demanda nacionais por filmes brasileiros, bem como ilustram os padrões de incentivo ao cinema nacional. Para tanto, foram utilizadas informações correspondentes ao período que se estende de 1995 a 2016.

Discernindo a origem regional dos filmes brasileiros, evidencia-se, na tabela 4.6 a considerável concentração da produção de cinema no estado do Rio de Janeiro, uma vez que quase a metade dos filmes exibidos durante todo o período disponível remete a esse estado. Da mesma forma, o público médio dos filmes do Rio de Janeiro reflete a predileção do consumidor de cinema nacional por produções desse estado: a sua média é 55\% superior à média nacional, além de ser mais de duas vezes maior do que a correspondente ao segundo estado mais importante do mercado, São Paulo. Esse também concentra uma 
parcela substancial da produção e igualmente apresenta um público médio bastante superior ao dos demais estados.

Tabela 4.6 - Estatísticas de público de filmes nacionais por UF

\begin{tabular}{lcccccc}
\hline & \multicolumn{2}{c}{ Pré-Ancine } & \multicolumn{2}{c}{ Pós-Ancine } & \multicolumn{2}{c}{ 1995-2016 } \\
\hline \multicolumn{1}{c}{ UF } & Filmes & Média & Filmes & Média & Filmes & Média \\
\hline RJ & $136(63 \%)$ & 356.837 & $528(46 \%)$ & 323.201 & $664(48 \%)$ & 330.089 \\
SP & $62(29 \%)$ & 201.037 & $406(35 \%)$ & 130.202 & $468(34 \%)$ & 139.586 \\
RS & $7(3 \%)$ & 146.733 & $55(5 \%)$ & 21.872 & $62(5 \%)$ & 35.969 \\
PE & $1(0,5 \%)$ & 73.062 & $32(3 \%)$ & 25.031 & $33(2 \%)$ & 26.486 \\
MG & $2(0,9 \%)$ & 41.008 & $30(3 \%)$ & 12.093 & $32(2 \%)$ & 13.900 \\
DF & $2(0,9 \%)$ & 18.199 & $26(2 \%)$ & 14.769 & $28(2 \%)$ & 15.014 \\
Outros estados & $6(3 \%)$ & 10.962 & $77(7 \%)$ & 33.946 & $83(6 \%)$ & 32.284 \\
\hline Total & 216 & 288.326 & 1.154 & 198.333 & 1.370 & 212.521 \\
\hline
\end{tabular}

Fonte: Ancine. Elaboração própria.

O pré-Ancine apresentava uma concentração ainda maior no RJ, conforme se observa que mais de $60 \%$ dos filmes exibidos antes do funcionamento da agência correspondiam àquele estado. A queda de 17 pontos percentuais na participação de mercado do RJ ocorre em contrapartida a uma maior importância assumida pelo estado de SP, ainda que chame mais a atenção o forte crescimento da produção dos outros estados: Rio Grande do Sul, Pernambuco, Minas Gerais e Distrito Federal tiveram sua participação no total exibido quase ou mais do que duplicada, o mesmo se aplicando aos demais estados brasileiros. Quanto ao público, porém, considerando a tendência geral de queda no público médio, apenas o RJ manteve uma proporção expressiva, no pós-Ancine, do público médio verificado em anos anteriores: a queda para esse estado foi de apenas 10\%, enquanto que a queda para SP foi de $35 \%$ e para o RS foi de expressivos $85 \%$. Assim, embora a exibição sugira uma diversificação regional no pós-Ancine, a variável de público indica uma concentração do consumo de filmes nacionais sobre as produções do RJ.

A análise por gênero da produção e do consumo de cinema nacional, apresentada na tabela|10.5 do anexo, estabelece que, como sugerido pela descrição da interação entre as categorias de origem e de gênero, a comédia nacional tem elevadas médias de público, conforme as três principais categorias de gênero nacional remetem à comédia (Comédia e Aventura, Comédia, Comédia e Romance). O público agregado do gênero de comédia, inclusive, alcança expressivos 110 milhões de pessoas (38\% do público de cinema nacional 
acumulado). Quanto à exibição, destaque para os documentários, que concentram $34 \%$ do total exibido, ao mesmo tempo em que sua média de público é de apenas 10.461 pessoas, e para o gênero de drama, com 33\% do total exibido. O terceiro gênero com maior proporção de exibição consiste justamente na comédia, que representa $9 \%$ do total exibido.

Tabela 4.7 - Estatísticas de público de filmes nacionais por gênero, pré e pós-Ancine

\begin{tabular}{lcccccc}
\hline & \multicolumn{2}{c}{ Pré-Ancine } & \multicolumn{2}{c}{ Pós-Ancine } & \multicolumn{2}{c}{ 1995-2016 } \\
\hline Gênero & Filmes & Média & Filmes & Média & Filmes & Média \\
\hline Comédia & $22(10 \%)$ & 455.722 & $108(9 \%)$ & 906.156 & $130(9 \%)$ & 829.929 \\
Documentário & $37(17 \%)$ & 29.994 & $423(37 \%)$ & 8.752 & $460(34 \%)$ & 10.461 \\
Ação & $14(6 \%)$ & 646.751 & $47(4 \%)$ & 528.492 & $61(4 \%)$ & 555.633 \\
Aventura & $7(3 \%)$ & 921.968 & $28(2 \%)$ & 622.216 & $35(3 \%)$ & 682.167 \\
Drama & $88(41 \%)$ & 130.983 & $358(31 \%)$ & 129.061 & $446(33 \%)$ & 129.440 \\
\hline Total & 216 & 288.326 & 1.154 & 198.333 & 1.370 & 212.521 \\
\hline
\end{tabular}

Fonte: Ancine, IMDb. Elaboração própria.

Discriminando os números por categoria de gênero em pré e pós-Ancine, observa-se, na tabela 4.7, como o público médio de comédia surpreendentemente se elevou, indo na direção contrária à tendência geral; a média de público de comédia se tornou quase duas vezes superior no período de funcionamento da agência em comparação ao período anterior. Surpreende também o crescimento considerável da exibição de documentários: de $17 \%$ a sua participação se expandiu para $37 \%$, paralelamente a uma queda na média de público do gênero de $71 \%$.

Enunciar o incentivo ao cinema nacional no período 1995-2016 envolve a exposição, sobretudo, da quantidade de filmes incentivados e de valores monetários médios, distinguindo categorias de gênero, períodos de interesse e mecanismos de incentivo. Pelo exposto no capítulo de descrição da política pública, o principal instrumento de fomento ao cinema nacional das últimas décadas consistiu no incentivo fiscal, através da Lei do Audiovisual e da Lei Rouanet. A análise do incentivo ao cinema nacional, portanto, inicia com o instrumento da renúncia fiscal.

O valor captado médio no período 1995-2016 foi de $\mathrm{R} \$ 2.565 .600$ (considerando todos os filmes nacionais, incentivados ou não), ou de $\mathrm{R} \$ 3.489 .768$ (considerando apenas filmes com captação positiva). Os números de filmes nacionais incentivados através de mecanismos de renúncia fiscal apresentam acelerações no crescimento do incentivo em 
dois períodos que coincidem com transformações institucionais: a consolidação da Lei do Audiovisual, ao longo da segunda metade da década de 1990, resulta na dispersão do incentivo fiscal. Por sua vez, a incumbência da Ancine de fomento ao audiovisual parece ter se revertido, a partir de 2004, em um maior ritmo de aprovação de pedidos de incentivo fiscal, conforme verificado na figura 4.6 . O período pós-FSA, no entanto, demonstra uma desaceleração do crescimento dos filmes incentivados fiscalmente, o que se associa ao esgotamento desse instrumento de incentivo e à sua substituição pelo investimento através do fundo.

A proporção de filmes incentivados com relação ao total exibido indica que a indústria soube evoluir sem recursos públicos, na medida em que o crescimento do total exibido ocorreu em um ritmo maior do que o crescimento dos filmes incentivados. Isso pelo menos até 2008, ano a partir do qual a diminuição na proporção incentivada via renúncia fiscal pode refletir também a substituição do instrumento de incentivo principal da política pública, dado o início das operações do FSA. Reforçando como o número de filmes exibidos cresceu mais do que o número de filmes incentivados, também a média do valor captado caiu ao longo dos anos (figura 10.1 do anexo). Logo, não somente o número de filmes incentivados, como também o valor total incentivado anualmente caiu comparativamente ao número de filmes exibidos.

Enquanto uma medida de eficiência do gasto, foi calculada a média anual da razão entre o valor captado com incentivo fiscal e a renda de bilheteria para cada filme. Observase da figura 4.7 que, no pós-Ancine, por volta de 2005, cresce fortemente essa proporção, indicando que cada real incentivado passou a se converter menos em renda de bilheteria. Não somente isso, durante todo o período considerado, a proporção média foi bastante superior a 1, de modo que, na média, a bilheteria de filmes com captação de recursos esteve distante do montante incentivado via renúncia fiscal. Com efeito, analisando a distribuição da proporção entre o valor captado com incentivo fiscal e a renda de bilheteria, exclusivamente para filmes com captação positiva, encontra-se que apenas o percentil 17,5\% apresenta uma razão menor ou igual à unidade. Logo, dos filmes que captam recursos com incentivo fiscal, 82,5\% deles não alcança uma renda de bilheteria suficiente para equivaler o montante de renúncia fiscal a eles dedicado. A análise dessa proporção por categoria de gênero demonstra que dos cinco gêneros com menor média, quatro se associam à comédia, de modo que essa classe de filmes representa aquela para a qual o 
Figura 4.6 - Filmes nacionais incentivados via renúncia fiscal e proporção do total exibido por ano

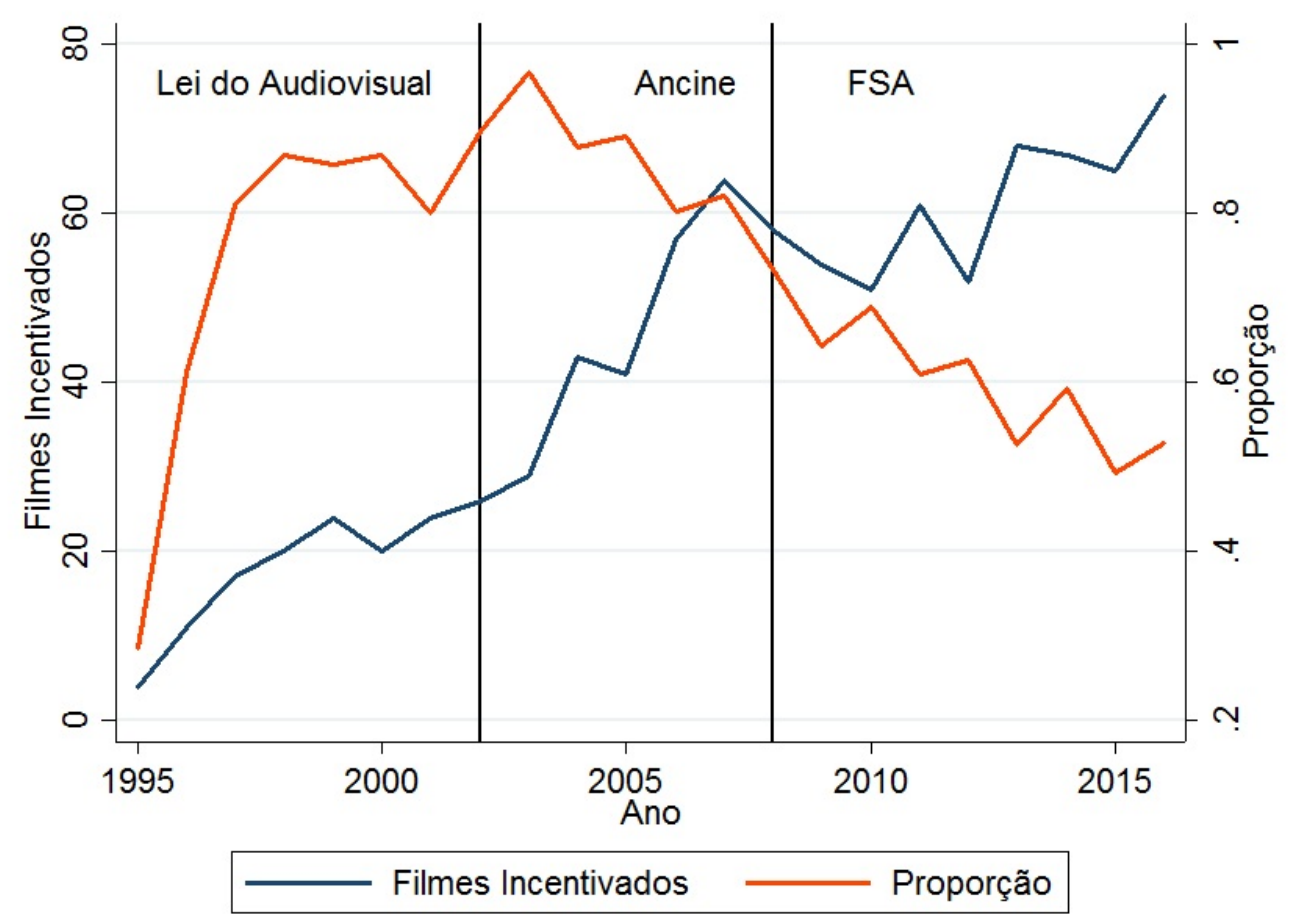

Fonte: Ancine. Elaboração própria.

incentivo fiscal mostrou-se mais eficiente. Do outro lado, os documentários apresentam o maior valor médio $(71,9)$, categoria cujo incentivo é mais ineficiente.

Relacionando aos valores captados com incentivo fiscal os gêneros dos filmes nacionais, e considerando a distinção temporal entre pré e pós-Ancine, verifica-se que, com o funcionamento da agência, cresceu consideravelmente a proporção do total do valor captado com incentivo fiscal que se destina a documentários, passando de 3,4\% para 11\%. O peso dos gêneros da comédia (incluindo as interseções com outros gêneros), do drama, da aventura e da ação se reduziu para que uma proporção maior de recursos financiasse a produção não somente de documentários: a participação da animação aumentou de 0,96\% para $2,9 \%$ e os demais gêneros tiveram sua participação elevada de $1,6 \%$ para $5,4 \%$. Claramente, há uma tendência, no pós-Ancine, à diversificação do incentivo considerando as diversas categorias de gênero disponíveis.

De acordo com a tabela 4.8 , semelhante à tabela 4.7 , ainda que represente uma parcela considerável do número total de filmes incentivados entre 1995 e 2016 (quase 30\%), o valor médio do incentivo a documentários é reduzido, representando apenas $26 \%$ do valor 
Figura 4.7 - Razão média entre o valor captado com incentivo fiscal e a renda de bilheteria por ano

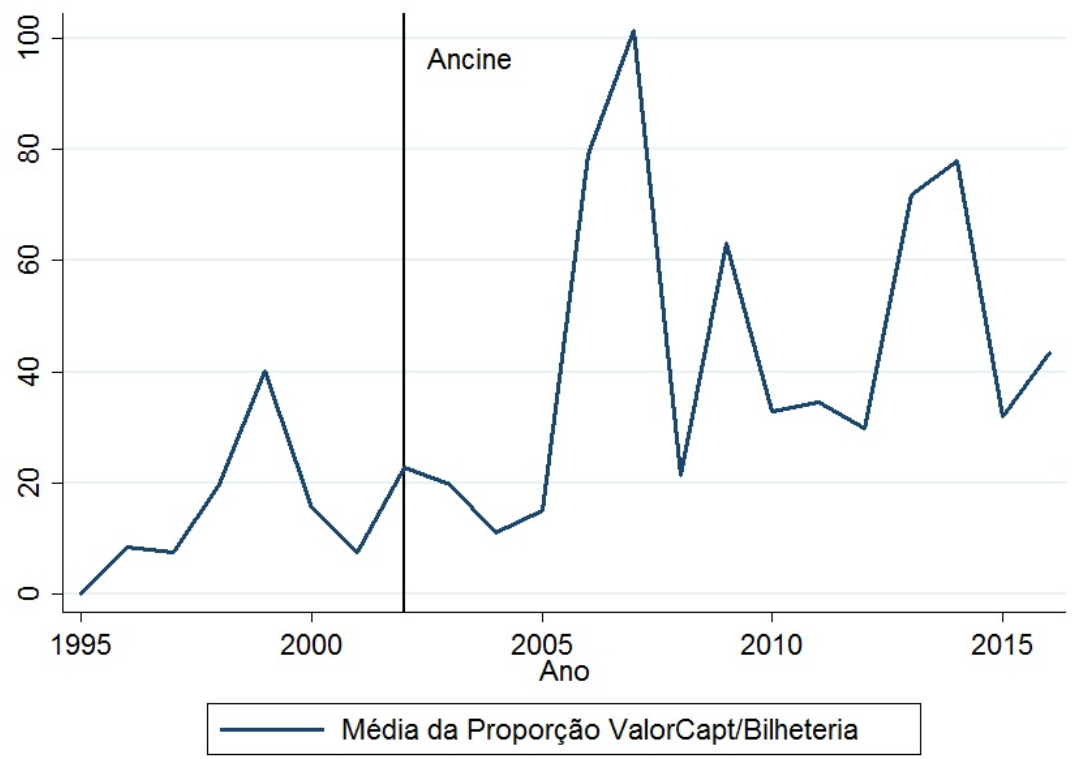

Fonte: Ancine. Elaboração própria.

incentivado médio para os filmes em geral, o que é compatível com a menor complexidade das produções documentais. Inclusive, no pós-Ancine, a média do valor captado cai para esse gênero, embora a proporção do total de filmes incentivados cresça consideravelmente, passando de $13 \%$ para $30 \%$. O pós-Ancine também revela uma maior preocupação da política de fomento com relação ao gênero da comédia (considerada exclusivamente). Cresce não somente a proporção do total de filmes com captação (de $9 \%$ para 12\%), como se expande fortemente a média do valor captado com incentivo fiscal por essa classe de filmes. A associação da tabela 4.8 com a tabela 4.7 ilustra um movimento análogo do público e do valor captado para o gênero da comédia: ambos se expandem após o funcionamento da Ancine, mesmo que a tendência geral seja de queda para as duas variáveis.

A compreensão dos padrões de incentivo fiscal a filmes nacionais é beneficiada pelo estabelecimento da influência de produtoras/distribuidoras sobre as médias de valor captado e de público. Começando por essa última variável, a média de público de filmes nacionais que contam com a participação, em termos de produção ou distribuição, das cinco maiores empresas do segment $5^{5}$ é de 835.783 pessoas, quase quatro vezes superior à média nacional indiscriminada (212.521 pessoas). O porte mais elevado das produções

5 Nomeadamente: Globo Filmes, Conspiração Filmes, Gullane Filmes, Filmes do Equador e Diler \& Associados. 
Tabela 4.8 - Captação de incentivo fiscal por gênero, pré e pós-Ancine (em reais de 2016)

\begin{tabular}{lcccccc}
\hline 1995-2016 & \multicolumn{2}{c}{ Pré-Ancine } & \multicolumn{2}{c}{ Pós-Ancine } & \multicolumn{2}{c}{ 1995-2016 } \\
\hline Gênero & Filmes* & Média & Filmes* & Média & Filmes* & Média \\
\hline Comédia & $15(9 \%)$ & 2.604 .155 & $91(12 \%)$ & 4.042 .784 & $106(11 \%)$ & 3.789 .585 \\
Documentário & $22(13 \%)$ & 848.282 & $228(30 \%)$ & 650.152 & $250(27 \%)$ & 667.946 \\
Ação & $14(8 \%)$ & 6.843 .905 & $35(5 \%)$ & 4.016 .397 & $49(5 \%)$ & 4.723 .274 \\
Aventura & $7(4 \%)$ & 8.990 .608 & $15(2 \%)$ & 4.009 .899 & $22(2 \%)$ & 5.099 .429 \\
Drama & $74(42 \%)$ & 4.357 .401 & $258(34 \%)$ & 2.711 .317 & $332(36 \%)$ & 3.055 .392 \\
\hline Total & 175 & 4.276 .602 & 755 & 2.213 .287 & 930 & 2.565 .600 \\
\hline
\end{tabular}

Fonte: Ancine, IMDb. Elaboração própria.

* Número de filmes incentivados via renúncia fiscal.

associadas a essas grandes empresas implica também na tendência a um valor captado médio superior: ao invés dos $\mathrm{R} \$ 2.565 .600$ da média nacional, a média para grandes produtoras é de $\mathrm{R} \$ 5.513 .157$. Como uma contrapartidd ${ }^{6}$ é necessária para o recebimento de recursos de incentivo fiscal, produções de grande porte, com orçamentos elevados, são factíveis para grandes produtoras e propensas a captar volumes consideráveis, uma vez que tais empresas dispõem de liquidez para garantir a proporcionalmente mais elevada contrapartida.

Também a realização de um filme por um diretor experiente influencia as médias de público e de valor captado. A tabela 10.6 do anexo demonstra que, dos 855 diretores de filmes nacionais listados na base de dados, a grande maioria (611, isto é, 71\%) dispõe de apenas um filme em sua carreira, embora seja necessário destacar que vários desses diretores correspondem a combinações de mais de um nome em trabalhos de co-direção. A média de público dessa categoria, ainda assim, é bastante inferior à média de público em geral para filmes nacionais: 93.593 pessoas, o que consiste em $44 \%$ da média geral. Acrescenta-se a isso que a média de público de filmes com diretor cuja carreira apresenta mais de um filme nacional (304.100 pessoas) seja estatisticamente superior à média para filmes com diretor de apenas uma realização.

Um padrão análogo se verifica para a média do valor captado com incentivo fiscal. As duas maiores médias se aplicam a filmes com diretor de 7 ( $\mathrm{R} \$ 5.028 .488)$ e de 4 produções ( $\mathrm{R} \$ 4.308 .676)$, valores que são quase o dobro da média geral e quase quatro vezes a média de captação de filmes com diretor de apenas uma obra. Partindo de um cálculo diferente,

6 Dentro da Lei do Audiovisual, a contrapartida corresponde a um mínimo de $5 \%$ do orçamento global aprovado. 
a tabela 10.7 expõe médias de público e de valor captado por experiência prévia do diretor, definida como o número de filmes realizados anteriormente ao filme em consideração. Para essa variável categórica, os filmes de diretores novatos têm quase a metade da média geral de público. Em particular quanto aos recursos incentivados, a sua média alcança um máximo para diretores que dispuseram de três filmes já realizados no momento da captação e, ademais, cresce de forma estatisticamente significativa o valor captado médio por filmes cujo diretor apresente ao menos uma realização prévia em comparação a filmes de novos diretores.

É conveniente correlacionar os valores captados com incentivo fiscal com a renda de bilheteria, na medida em que essas duas variáveis compartilham de uma mesma unidade de medida. Quanto à bilheteria, o seu valor médio para filmes nacionais é de $\mathrm{R} \$$ 2.837.207, com máximo de $\mathrm{R} \$ 156$ milhões. Em virtude da proporcionalidade, ressalta-se que o comportamento da renda de bilheteria é semelhante ao do público na relação com distintas categorias de origem e de gênero. Além disso, a média da variável preço médio do ingresso, dada pela razão entre a renda de bilheteria e o público de um filme, corresponde a $\mathrm{R} \$ 14,14$. Considerando apenas filmes estrangeiros, a média dessa variável é levemente superior, consistindo em $\mathrm{R} \$ 14,58$. Já para filmes nacionais, percebe-se uma rentabilidade inferior, uma vez que a média do preço médio do ingresso é de $\mathrm{R} \$ 12,92^{7}$. No entanto, considerando produções nacionais associadas a grandes produtoras/distribuidoras, a média do preço médio do ingresso é mais elevada, alcançando $\mathrm{R} \$ 13,47$. A figura 4.8 ilustra a associação positiva entre a renda de bilheteria e o valor captado com incentivo fiscal, com uma aparentemente elevada elasticidade.

Finalizando a descrição do incentivo ao cinema nacional, são expostas estatísticas, na tabela 4.9 , quanto aos dois instrumentos de fomento complementares à renúncia fiscal: as outras fontes de captação e o investimento do FSA. De 2008 até 2016, 170 filmes exibidos receberam recursos que se podem caracterizar como consistindo em outras fontes de captação, que não correspondam ao incentivo fiscal, sob a Lei do Audiovisual ou a Lei Rouanet, e nem ao investimento direto através do FSA. Compõem essa classificação, sobretudo, recursos do Programa Ancine de Incentivo à Qualidade (PAQ) e do Programa Adicional de Renda (PAR), além de, em menor magnitude, valores oriundos de leis mu-

7 Um teste de comparação de média confirma que se pode rejeitar, a um nível de significância de $1 \%$, a hipótese nula de que o preço médio do ingresso dos filmes nacionais é superior ao dos filmes internacionais. 
Figura 4.8 - Bilheteria contra o valor captado com incentivo fiscal

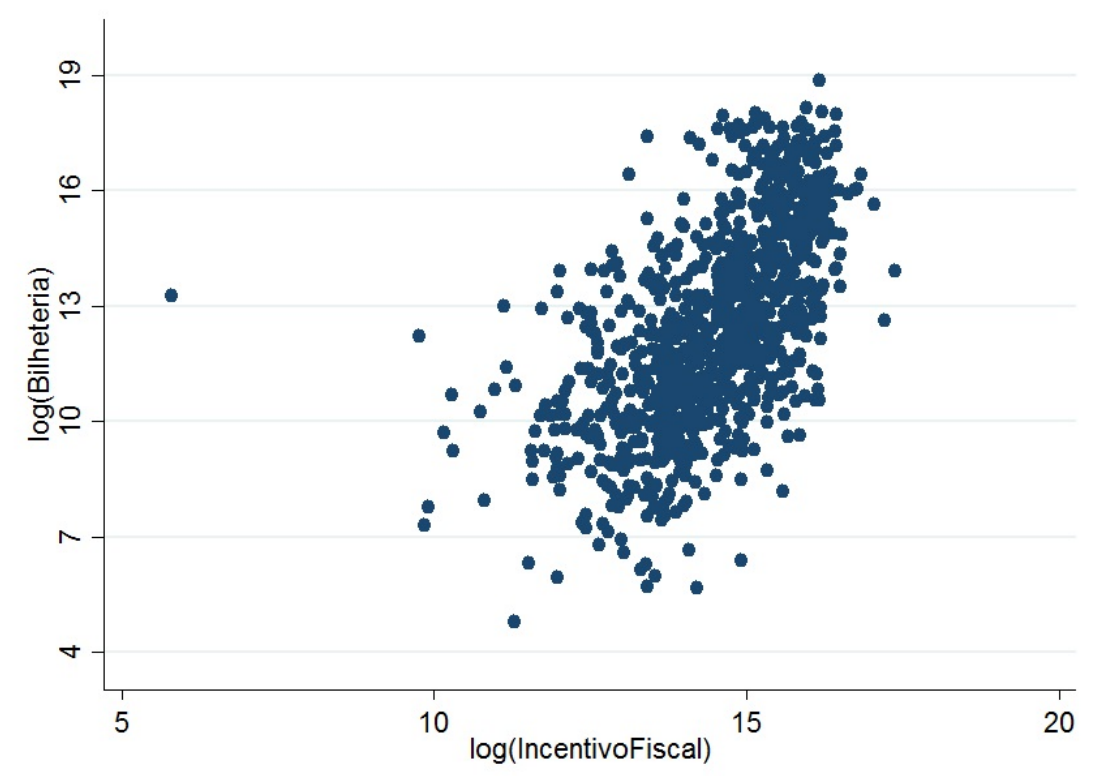

Fonte: Ancine. Elaboração própria.

nicipais ou estaduais. A média de valor captado apenas para filmes com captação é de $\mathrm{R} \$ 733.405$, número bastante inferior à média de valor captado com incentivo fiscal $(\mathrm{R} \$$ 2.565.600, considerando todos os filmes nacionais, incentivados ou não, ou $\mathrm{R} \$ 3.489 .768$, considerando apenas os filmes com captação). Condicionando as médias por gênero, percebe-se uma ênfase ao drama e aos demais gêneros (exceto comédia documentário e drama), sugerindo diversificação, em termos de categoria de gênero, na utilização desse instrumento de incentivo. Comparativamente ao incentivo fiscal, a atenção dada aos documentários é inferior, pois $22 \%$ dos filmes incentivados com outras fontes de captação corresponde a esse gênero, contra $27 \%$ do verificado com a captação fiscal.

Tabela 4.9 - Valores incentivados através de fontes não fiscais (em reais de 2016)

\begin{tabular}{lcccc}
\hline & \multicolumn{2}{l}{ Outras Fontes de Captação } & \multicolumn{2}{c}{ Investimento FSA } \\
\hline Gênero & Filmes* & Valor Total & Filmes* & Valor Total \\
\hline Comédia & $17(10 \%)$ & $18,2 \mathrm{mi}(15 \%)$ & $21(15 \%)$ & $49 \mathrm{mi}(32 \%)$ \\
Documentário & $37(22 \%)$ & $10,4 \mathrm{mi}(8 \%)$ & $8(6 \%)$ & $2,6 \mathrm{mi}(2 \%)$ \\
Drama & $67(39 \%)$ & $46 \mathrm{mi}(37 \%)$ & $49(35 \%)$ & $42 \mathrm{mi}(28 \%)$ \\
Outros gêneros & $49(29 \%)$ & $50,1 \mathrm{mi}(40 \%)$ & $62(44 \%)$ & $58,4 \mathrm{mi}(38 \%)$ \\
\hline Total & 170 & $124,7 \mathrm{mi}$ & 140 & $152 \mathrm{mi}$ \\
\hline
\end{tabular}

Fonte: Ancine. Elaboração própria.

* Filmes incentivados para cada mecanismo. 
De 2008 até 2016, 140 filmes exibidos receberam investimentos do FSA. O valor médio, dentre os filmes investidos, representa uma magnitude mais expressiva em comparação às outras fontes, $\mathrm{R} \$ 1.086 .572$, montante que, contudo, ainda é inferior ao valor médio de incentivo fiscal. Analisando a distribuição dos recursos por gênero, fica ainda mais claro o menor peso atribuído aos documentários, pois apenas $6 \%$ dos filmes investidos são desse gênero, enquanto que a proporção do total investido é ainda inferior (2\%). Ao mesmo tempo, a participação do gênero da comédia no total investido é destacada (32\%), representando o gênero específico com maior captação proporcional junto ao fundo.

Considerando que o incentivo fiscal é auto-selecionado, em decorrência dos projetos pleitearem recursos e serem investidos por agentes não envolvidos diretamente com a política pública, conclui-se que há uma grande propensão da indústria de cinema brasileira a produzir documentários, principalmente reconhecendo-se que instrumentos de incentivo mais discricionários, como ocorre com as outras fontes e com o investimento do FSA, dedicam-se pouco àquele gênero. Desperta interesse também como o investimento do FSA tem se dedicado ao gênero da comédia, o qual já se demonstrou ser consideravelmente mais rentável do que a média. A viabilidade financeira do instrumento de incentivo representado pelo fundo parece ser, assim, uma diretriz desse mecanismo de fomento.

Uma última estatística a ser apresentada contribui adicionalmente para a descrição da estrutura e, em particular, do funcionamento da indústria nacional de cinema. Definese o tempo estimado de produção de um filme nacional como a diferença entre o ano de exibição do filme e o primeiro ano de pedido de incentivo fiscal. Como os filmes tendem a fazer um primeiro pedido durante a sua fase de pré-produção, a distância no tempo entre esse primeiro pedido e o ano de exibição proporciona uma estimação do tempo necessário para um filme concluir a sua produção e, igualmente, a sua distribuição e exibição. Portanto, como indicado pela tabela 4.10 , estima-se em 4 anos o tempo médio para um filme nacional ser produzido e finalizado. Os principais gêneros com tempo de produção inferior à média geral são a comédia e o documentário (por volta de 3 anos e meio), sendo a animação e a aventura os gêneros com tempos de produção estimados superiores à média (por volta de 5 anos).

Resumindo as principais constatações desta seção, quanto à demanda por cinema brasileiro e quanto à estrutura da indústria nacional, verifica-se uma concentração da produção de cinema no estado do Rio de Janeiro, o que se atenuou no pós-Ancine. No 
Tabela 4.10 - Tempo estimado de produção médio (em anos)

\begin{tabular}{lcc}
\hline Gênero & Tempo Médio & Máximo \\
\hline Gêneros de Ação & 4,02 & 12 \\
Animação & 5,06 & 10 \\
Gêneros de Aventura & 5,09 & 11 \\
Gêneros de Comédia & 3,5 & 12 \\
Documentário & 3,7 & 15 \\
Drama & 4,6 & 20 \\
\hline Total & 4,07 & 20 \\
\hline
\end{tabular}

Fonte: Ancine, IMDb. Elaboração própria.

período de funcionamento da agência, diversificou-se a origem regional dos filmes nacionais exibidos. O público, porém, caiu consideravelmente mais para os estados à exceção do Rio de Janeiro, confirmando a predileção do consumidor de cinema nacional por obras oriundas desse estado. A análise por gênero mostra que as categorias com maiores médias de público remetem à comédia, sendo que a categoria exclusiva de comédia surpreendentemente elevou seu público médio no pós-Ancine. Nesse período, cresceu também de forma expressiva a exibição de documentários, a despeito da forte queda em seu público esperado.

Quanto aos padrões do incentivo ao cinema nacional (considerando os valores que se aplicam a filmes exibidos), associam-se as acelerações no crescimento do número de filmes incentivados através da renúncia fiscal com a consolidação da Lei do Audiovisual e com o funcionamento da Ancine. O pós-FSA, porém, apresenta uma desaceleração no crescimento dos filmes com captação fiscal. A queda na proporção de filmes incentivados com relação ao total exibido sugere que a indústria soube evoluir sem recursos públicos, isso pelo menos até 2008, ano a partir do qual a queda naquela proporção pode estar associada à substituição do mecanismo de fomento principal, dado o início das operações do fundo. O incentivo fiscal aparenta ter sido ineficiente, tendo em vista a enorme proporção de filmes incentivados cuja renda de bilheteria não alcançou os valores a eles destinados. Fazendo a distinção por gênero, as categorias de comédia mostraram-se relativamente mais eficientes, enquanto que a categoria de documentário apresentou a pior média da razão entre o valor captado e a bilheteria.

Com o funcionamento da Ancine, houve uma diversificação entre as categorias de gênero na participação dos valores totais incentivados, com os documentários sendo a 
categoria com maior crescimento na sua proporção do total, isso graças à forte elevação do número de documentários incentivados. Também o gênero da comédia recebeu maior atenção da política de fomento, consistindo na única categoria com elevação do valor captado médio. Confirmou-se empiricamente que os filmes associados a grandes produtoras ou distribuidoras têm público médio e valor captado médio superiores. Outra constatação indicou um preço médio do ingresso para filmes nacionais inferior estatisticamente ao preço médio para filmes internacionais. Ficou estabelecida também a forte associação positiva entre a renda de bilheteria e o valor captado com incentivo fiscal.

Por fim, as outras fontes de captação apresentaram uma aplicação diversificada entre os gêneros, com menor peso atribuído aos documentários. Já o investimento do FSA também não mostrou a mesma ênfase no fomento a esse gênero do que o verificado com o incentivo fiscal, ao contrário da comédia, que concentra uma proporção destacada dos recursos investidos pelo fundo. Foi possível concluir quanto a uma propensão da indústria nacional à produção de documentários e quanto a uma atenção especial do fundo a um gênero particularmente rentável, como ocorre com a comédia.

\subsection{Exemplos de filmes específicos}

Esta seção objetiva tornar mais concretas as constatações das subseções anteriores, na medida em que são ilustrados alguns padrões dos dados através da listagem de filmes específicos. Por exemplo, os filmes de maior público e bilheteria são coerentes com a predileção do consumidor brasileiro de cinema pelo gênero da aventura, demonstrada na

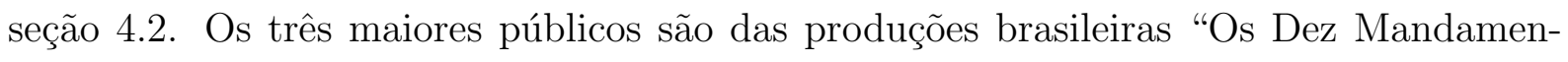
tos" (2016), aventura com público de 11,3 milhões de pessoas, e "Tropa de Elite 2"(2010), ação com público de 11,1 milhões de pessoas, além de "Os Vingadores"(2012), ação e aventura norte-americana com público de 10,9 milhões de pessoas.

Em termos de bilheteria, destacam-se "Os Vingadores" (2012), ação e aventura norteamericana com renda de bilheteria de $\mathrm{R} \$ 174$ milhões (a preços de 2016), "Os Vingadores - Era de Ultron"(2015), também uma ação e aventura norte-americana com bilheteria de R\$ 159 milhões, e "Tropa de Elite 2" (2010), ação brasileira com faturamento no cinema de $\mathrm{R} \$ 156$ milhões. Adicionalmente, dois dos 30 filmes mais convencionais, com valores máximos do índice de convencionalidade, ilustram a tentativa de definir os atributos de 
filmes pelos quais a sua aceitação junto ao público consumidor seja imediata. A produção "A.I Inteligência Artificial" (2001) foi uma obra de aventura norte-americana produzida e distribuída por empresas como a Warner Bros. e a DreamWorks e cujo diretor, Steven Spielberg, havia vencido o prêmio Oscar de melhor diretor duas vezes previamente ao seu lançamento (1993 e 1998). Já "Um Conto de Natal" (2009) consistiu em uma animação norte-americana produzida e distribuída pela Walt Disney, tendo por diretor Robert Zemeckis, vencedor do Oscar em 1995.

Uma combinação de gênero e origem que despertou a atenção durante a exposição das estatísticas foi a comédia nacional. Exemplificando a elevação de patamar, no pósAncine, do público esperado desse gênero de filme nacional, é listado o filme de maior público para cada um dos períodos de referência: no pré-Ancine, "Os Normais" (2003), de José Alvarenga Jr. e produzido e distribuído pela Globo Filmes, teve público de 2.996.467 pessoas e captou com incentivo fiscal $\mathrm{R} \$ 3.232 .746$ (a preços de 2016), sendo a sua renda de bilheteria mais de 13 vezes superior ao valor captado; no pós-Ancine, "Se Eu Fosse Você 2" (2009), de Daniel Filho com produção e distribuição da Globo Filmes, teve público de 5.787.244 pessoas e um valor captado com incentivo fiscal de $\mathrm{R} \$$ 8.575.026, ao mesmo tempo em que seu faturamento com bilheteria foi mais de 8 vezes superior ao total incentivado.

Observando filmes nacionais com valores captados expressivos, "Chatô - O Rei do Brasil" (2015), cujo tempo estimado de produção é de 20 anos, teve a maior captação, com $\mathrm{R} \$ 35,5$ milhões incentivados (a preços de 2016) e uma renda de bilheteria correspondendo a apenas $3 \%$ desse valor. A segunda maior captação decorre do filme "Coração Iluminado"(1998), para o qual a captação foi de R $\$ 29,6$ milhões, com uma bilheteria que alcançou apenas 1\% do total captado. Focando no gênero do documentário, que recebeu particular atenção da política de fomento, ao mesmo tempo em que seu público esperado é o menor dentre todos os gêneros, o documentário "Pelé Eterno"(2004) captou $\mathrm{R} \$ 9.198 .159$, dispondo de uma bilheteria de $41 \%$ desse valor. Com um desempenho de público ainda pior, a segunda maior captação corresponde ao filme "Amazônia Eterna" (2014), cuja captação com incentivo fiscal alcançou $\mathrm{R} \$ 5.830 .122$, embora a sua bilheteria tenha sido de apenas $\mathrm{R} \$ 3.493$, o que equivale a desprezíveis $0,0006 \%$ do valor captado.

Com relação às maiores ineficiências do incentivo fiscal, o drama "O Quinze" (2007) 
captou $\mathrm{R} \$ 2.994 .269$ (a preços de 2016), enquanto que a sua razão entre o valor captado e a renda de bilheteria alcança a proporção de 5.178, tendo em vista a sua bilheteria de apenas R \$ 578. O documentário "Por Trás do Véu"(2013), cujo público foi o terceiro menor de toda a base (apenas 15 pessoas), teve por valor incentivado com renúncia fiscal $\mathrm{R} \$ 1.474 .442$, valor 5.041 vezes superior à sua renda de bilheteria $(\mathrm{R} \$ 292)$. Inversamente, considerando os filmes com captação positiva e com as menores razões de valor captado por bilheteria, encontra-se o drama e romance brasileiro "Casa Grande" (2015), com captação de apenas $R \$ 331$ (a preços de 2016) e com uma bilheteria cujo valor representa mais de 1.719 vezes o total incentivado ( $\mathrm{R} \$ 570.078)$. Já a comédia "Vai que Dá Certo" (2013), cuja captação foi mais expressiva, de $\mathrm{R} \$ 668.127$, teve por faturamento no cinema um valor quase 55 vezes superior ao seu total captado ( $\mathrm{R} \$ 36,5$ milhões).

\subsection{Considerações importantes para a metodologia}

Organizam-se as conclusões das estatísticas descritivas que se aplicam à metodologia de acordo com os seguintes seis tópicos principais:

i) Modificações pronunciadas no comportamento de variáveis dependentes.

ii) Alterações em padrões de produção, consumo e incentivo no período pós-funcionamento da Ancine.

iii) Sugestão de um possível efeito do funcionamento da agência sobre o público esperado de filmes nacionais comparativamente ao de filmes internacionais.

iv) Importância da utilização de variáveis explicativas que caracterizam os filmes para explicar as variações do público esperado e importância do controle das características dos filmes para evitar o viés e a inconsistência dos estimadores do efeito de valores incentivados sobre variáveis de resultado.

v) Informações relevantes para a compreensão da dinâmica do tratamento em que consiste o funcionamento da Ancine, em particular, quanto à sua atribuição de promoção do fomento.

A primeira conclusão do que foi apresentado pelos dados que é importante para a metodologia consiste na constatação de que há uma associação entre os períodos de mu- 
danças institucionais e o comportamento da indústria e do mercado de cinema brasileiros. Em particular, verifica-se uma maior exibição de filmes nacionais e um maior número de filmes incentivados subsequente a momentos importantes da evolução institucional da política pública de cinema.

Quanto à segunda conclusão acima levantada, o pós-Ancine demonstrou uma diversificação da origem (internacional e regional) dos filmes exibidos. Constatou-se uma maior liberalidade na concessão de incentivos, bem como ocorreu uma diversificação entre os gêneros na distribuição do total incentivado com renúncia fiscal. Os documentários se destacaram na sua proporção do total de filmes incentivados e a comédia, inclusive, teve seu valor captado médio majorado no pós-Ancine. Esses dois gêneros despertaram particular interesse com o funcionamento da agência, também em virtude de o primeiro ter sua exibição consideravelmente elevada e de ao segundo ter se verificado uma inesperada elevação da média de público.

A terceira conclusão diz respeito a diferenças de médias de público para filmes nacionais e internacionais, estatística importante para uma metodologia de diferençasem-diferenças. Tomando a diferença entre os filmes nacionais e os filmes internacionais das diferenças entre o pós e o pré-Ancine, e realizando testes de hipóteses de diferenças de média entre os dois períodos para ambos os grupos, encontram-se evidências de que, com o funcionamento da agência, o público de filmes nacionais evoluiu positivamente em comparação ao de filmes internacionais. Trata-se de um resultado importante, embora seja necessário controlar as características relevantes dos filmes exibidos.

A quarta conclusão decorre das diferenças de médias de público e para distintas categorias de origem e de gênero, o que reforça que variáveis dummy representando a origem e o gênero são importantes para explicar o público esperado de um filme. Analogamente, para filmes nacionais, a origem regional, em especial, quanto à proveniência do RJ ou de outros estados, auxilia na explicação das variações do público esperado de obras brasileiras.

Por fim, a quinta conclusão considera que o tempo estimado de produção médio de 4 anos para filmes nacionais deve ser reconhecido na definição do tratamento em que consiste o funcionamento da Ancine. É conveniente definir variáveis de tratamento específicas para cada ano após 2004, flexibilizando o efeito de tratamento para variar conforme o ano e captar, portanto, o efeito defasado da promoção do fomento. 


\section{Metodologia}

O capítulo de metodologia se desenvolve a partir do objetivo da pesquisa de avaliar a política pública de cinema no Brasil, o que pressupõe conhecer as suas intenções, as formas pelas quais as intervenções foram realizadas e os desdobramentos esperados. Com base nisso, é preciso estabelecer claramente as questões investigadas e os modelos econométricos pertinentes.

\subsection{Objetivos da política pública e formas de tratamento}

O capítulo de descrição da política pública de cinema demonstrou que um conjunto bem definido de objetivos da política passou a existir apenas com a criação da Ancine. Subentende-se das leis de incentivo fiscal que sua motivação consistia em facilitar a produção de obras cinematográficas nacionais. Consoante a isso, a Medida Provisória que institui a agência estabelece explicitamente como diretriz geral da política garantir a presença do produto nacional no mercado interno, com o que são identificados os parâmetros da oferta de cinema como o foco da política. Inclusive, mesmo a intenção de promover a competitividade e a sustentabilidade da indústria nacional se justifica pelo aumento da produção e da exibição.

Avaliar a eficácia da política pública de cinema, tal como definido no objetivo da pesquisa, requer, então, a investigação do sucesso da política em ampliar o acesso do consumidor brasileiro ao cinema nacional. Compreende-se essa ampliação do acesso como uma combinação da expansão do conjunto de produções nacionais exibidas no país anualmente com a elevação do público médio dessas. Assim, a metodologia deve abranger duas métricas para o acesso a filmes nacionais: a exibição, quanto ao número de filmes exibidos e sua distinção entre produções nacionais e internacionais, e o público realizado de um filme, a que também se associa a bilheteria realizada.

A política pública dispõe de duas classes de instrumentos a fim de alcançar seus objetivos: a regulação e fiscalização e o fomento. Para melhorar as condições de acesso ao cinema nacional, à Ancine foi atribuída a competência de monitorar o mercado de uma tal forma que vigorassem reservas de mercado ao produto doméstico, buscando garantir 
que esteja à disposição do público consumidor. Adicionalmente, destacam-se medidas de promoção das obras nacionais através do apoio a festivais internos e à participação brasileira em festivais internacionais. Já os diversos mecanismos de fomento existentes, do incentivo fiscal ao investimento pelo FSA, estão orientados para facilitar a produção cinematográfica, a qual, sem esses recursos subsidiados, contaria com um financiamento mais oneroso.

Dessa forma, dos instrumentos de política disponíveis, distinguem-se duas formas de tratamento. O funcionamento da Ancine implica em uma regulação e fiscalização que protege a indústria nacional e que divulga o produto doméstico. Enquanto a proteção tem por resultado uma maior proporção de filmes nacionais em cartaz, à disposição, portanto, da escolha do consumidor, a divulgação do produto nacional reforça ao público a disponibilidade de uma alternativa às obras internacionais. A promoção do fomento igualmente compõe o funcionamento da agência e tem a capacidade de indiretamente impactar as variáveis de resultado, na medida em que facilite a captação de recursos.

A segunda forma de tratamento diz respeito aos incentivos monetários concedidos pela política de fomento através de recursos fiscais e de investimentos. Ao representar uma fonte de capital a baixo custo em comparação ao capital próprio e ao capital privado de terceiros, o incentivo monetário viabiliza um volume maior de produções e, além disso, aumenta a sua qualidade, conforme conduz a um orçamento mais robusto. Portanto, são esses os tratamentos a serem incorporados na metodologia para a avaliação da política pública de cinema na consecução de seus objetivos.

\subsection{Questões investigadas e modelos econométricos}

Para avaliar a eficácia da política pública em ampliar o acesso do consumidor brasileiro a filmes nacionais, foram levantadas as seguintes questões com os correspondentes modelos econométricos. De cada questão, enuncia-se a relação causal subjacente e, para cada modelo, será descrita a sua estrutura, considerando como parâmetros: a descrição e objetivo do modelo, a variável dependente, as variáveis explicativas principais, as variáveis de controle, a equação, a hipótese de identificação, as origens dos filmes para as quais se aplica o modelo, a extensão temporal, as restrições a serem impostas sobre a amostra e possibilidades de extensão. 


\subsubsection{A Ancine impactou a proporção de filmes nacionais exibidos?}

A relação causal que se aplica a essa questão parte do funcionamento da Ancine, conforme essa promova a política de fomento e regule e fiscalize o mercado de forma a garantir a vigência da legislação protetora do produto doméstico. Isso representa uma maior probabilidade de um projeto receber recursos fiscais e a garantia de uma maior proporção de obras brasileiras em exibição. Consequentemente, mais filmes nacionais são viabilizados, produzidos e, então, exibidos.

\section{Modelo que explica a probabilidade de um filme exibido ser nacional: re-} gressão de uma variável dummy indicando se o filme é nacional contra o tratamento do início das operações da Ancine.

O objetivo do modelo consiste em verificar o efeito do funcionamento da Ancine sobre a probabilidade de um filme exibido ser nacional, logo, deseja-se constatar a capacidade da agência de ampliar o acesso do consumidor brasileiro a filmes nacionais, considerando a métrica da exibição.

A variável dependente consiste na dummy Nacional $_{i t}$, sendo a dummy Ancine $_{i t}$ a variável explicativa principal. As variáveis de controle são dadas pelo conjunto de dummies Genero $_{i t}$ e pelo controle do tempo, $\delta_{t}$. A equação principal corresponde a:

$$
\text { Nacional }_{i t}=\alpha_{1}+\beta_{1} \text { Ancine }_{i t}+\text { Genero }_{i t} \lambda_{11}+\delta_{t}+\epsilon_{1 i t}
$$

Onde $\lambda_{11}$ é um vetor-coluna de parâmetros para as dummies de gênero presentes no vetor-linha Genero $o_{i t}$. Quanto à hipótese de identificação, seja $x_{1 i t}=$ $\left(1\right.$, Ancine $_{i t}$, Genero $\left._{i t}, \delta_{t}\right)$ o vetor de variáveis explicativas, supõe-se que: $E\left(x_{1 i t} . \epsilon_{i t}\right)=$ 0. Dessa forma, nenhum fator não observado que se associa à origem de um filme quanto a ser nacional ou internacional pode ter correlação com o período de funcionamento da Ancine, o gênero do filme e o seu ano de exibição.

As origens dos filmes para as quais se aplica o modelo são todas as dez categorias de origem definidas no capítulo 4, havendo a discriminação de um filme ser nacional ou internacional. Quanto à extensão temporal e ao recorte amostral, serão considerados todos os filmes exibidos no país entre 2001 e 2016.

As possibilidades de extensão exploradas dizem respeito, primeiramente, a formas funcionais alternativas para a probabilidade de um filme exibido ser nacional, 
na medida em que se estabeleçam modelos Probit e Logit. Além disso, é possível explorar, nos modelos de escolha binária, as diversas origens internacionais possíveis (EUA/Canadá, Europa Ocidental, etc.) em contraposição a filmes nacionais.

\subsubsection{O funcionamento da Ancine impactou o público de filmes nacionais frente ao de internacionais?}

A relação causal subjacente a essa questão propõe que as operações da Ancine de promoção do fomento e de proteção e divulgação do produto nacional aumentem o seu apelo junto ao consumidor, de modo que o desempenho de público dos filmes nacionais melhore frente ao dos internacionais.

2. Modelo de diferenças-em-diferenças para o público: regressão do público contra uma variável discernindo entre grupo de tratamento (filmes nacionais) e de controle (filmes internacionais), uma variável indicando se o ano de exibição do filme pertence a um intervalo de tempo do qual se espera que a Ancine pudesse operar plenamente e uma variável construída a partir da interação entre as duas citadas anteriormente. Essa interação representa o tratamento para filmes nacionais do início das operações da Ancine.

O objetivo principal do modelo consiste em verificar se, com o funcionamento da Ancine, o público de filmes nacionais foi impactado positivamente em comparação ao público de filmes internacionais, logo, busca-se auferir a contribuição da agência para a ampliação do acesso do consumidor brasileiro a filmes nacionais, comparativamente ao acesso a filmes internacionais, considerando a métrica do público realizado.

Também consta como um objetivo secundário verificar o efeito sobre o público de filmes nacionais da forma de tratamento em que consiste os valores incentivados, logo, também da política de fomento é estimada a capacidade de ampliação do acesso a filmes nacionais.

A variável dependente consiste no Publico $i t$, enquanto que as variáveis explicativas principais são Nacional $_{i t}$, Ancine $i t$ e a interação entre essas duas variáveis, Tratamento $_{i t}=$ Nacional $_{i t}$. Ancine $i t$, sendo responsável por captar a diferença entre os grupos de tratamento e de controle das diferenças do público esperado entre 
o pós e o pré-Ancine.

O grupo de tratamento consiste nos filmes nacionais, enquanto que o grupo de controle corresponde ao conjunto de filmes internacionais. O threshold para a variável Ancine $i t$ foi definido como sendo o ano de 2004.

Conforme demonstrado na seção 3.5, era previsto um período de pelo menos dois anos após a publicação da MP 2.228-1, em 2001, para que a agência dispusesse de infraestrutura física e de um funcionalismo próprio. Com efeito, o ano de 2004 representa o último do processo de estruturação das atividades da agência. Mais do que isso, a subseção 3.5.1 evidenciou que as medidas de regulação e de promoção do fomento têm aquele ano como início do seu período de vigência. Assim, projetam-se os inícios da proteção ao produto doméstico e da sua divulgação para o ano de 2004, de modo que são os filmes nacionais exibidos a partir desse ano que contam com essa forma de tratamento.

A tabela 4.10 e a conclusão vi) da seção 4.5 sugerem que os efeitos do funcionamento da Ancine podem ser ainda mais defasados, quando se considera sua incumbência de promoção dos instrumentos de incentivo. Dado o tempo estimado médio de produção de 4 anos, o que representa uma diferença média de 4 anos entre o ano de exibição e o ano de primeiro pedido de incentivo fiscal, conclui-se que, em média, os filmes exibidos a partir de 2007 contaram com um ambiente mais favorável à captação de recursos.

As variáveis de controle são dadas pelos vetores-linha Genero $i t$, Origem $i t$,

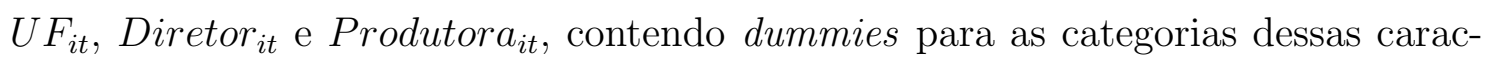
terísticas, além do efeito-fixo de tempo, $\delta_{t}$, e dos valores incentivados pela política de fomento, IncentivoFiscal ${ }_{i t}$, InvestimentoFS $A_{i t}$ e OutrasFontes It $_{\text {. Essas últimas }}$ são particularmente importantes por representarem, elas mesmas, uma forma de tratamento, de modo que seus efeitos parciais também possibilitam uma análise de eficácia da política pública. A equação de diferenças-em-diferenças é dada por:

$$
\begin{gathered}
\text { Publico }_{i t}=\alpha_{2}+\gamma_{2} \text { Nacional }_{i t}+\phi_{2} \text { Ancine }_{i t}+\text { BTratamento }_{i t}+ \\
\beta_{21} \text { IncentivoFiscal }_{i t}+\beta_{22} \text { InvestimentoFS }_{i t}+\beta_{23} \text { OutrasFontes }_{i t} \\
+ \text { Genero }_{i t} \lambda_{21}+\text { Origem }_{i t} \lambda_{22}+\text { UF }_{i t} \lambda_{23}+\text { Diretor }_{i t} \lambda_{24}+\text { Produtor }_{i t} \lambda_{25}+\delta_{t}+\epsilon_{2 i t}
\end{gathered}
$$


Onde $\lambda_{21}, \ldots, \lambda_{25}$ são vetores-coluna de parâmetros dos respectivos conjuntos de variáveis dummy. Considerando um cenário hipotético de ausência da criação e do funcionamento da Ancine a partir do ano de referência $t^{*}$, a diferença do valor esperado condicional para o público entre os períodos $t \geq t^{*}$ e $t<t^{*}$ deve ser igual para os grupos de tratamento e de controle. Sendo Publico $i t 0$ o público na ausência da criação e do funcionamento da Ancine a partir de $t^{*}, x_{2 i t}$ o vetor de variáveis explicativas e $T$ uma dummy discernindo entre grupo de tratamento e de controle, a hipótese de identificação do modelo de diferenças-em-diferenças é:

$$
\begin{aligned}
& E\left(\text { Publico }_{i t 0} \mid x_{2 i t}, T=1, t \geq t^{*}\right)-E\left(\text { Publico }_{i t 0} \mid x_{2 i t}, T=1, t<t^{*}\right) \\
= & E\left(\text { Publico }_{i t 0} \mid x_{2 i t}, T=0, t \geq t^{*}\right)-E\left(\text { Publico }_{i t 0} \mid x_{2 i t}, T=0, t<t^{*}\right)
\end{aligned}
$$

Dessa forma, supõem-se tendências paralelas para o público esperado dos grupos de tratamento e de controle, na ausência da criação e do funcionamento da Ancine a partir de $t^{*}$.

Todas as dez categorias de origem serão consideradas, havendo a discriminação principal de um filme ser nacional ou internacional. A extensão temporal abrange o período de 2001 a 2016. Com relação a restrições sobre a amostra, serão excluídos outliers abaixo e/ou acima de certos percentis (1\% e 99\%, ou 10\% e 90\%, por exemplo).

Por fim, uma possibilidade metodológica explorada envolve a aplicação do logaritmo natural sobre a variável dependente, a fim de captar possíveis não linearidades na relação entre essa e as variáveis explicativas. Outra possibilidade representa uma extensão à especificação de referência e também parte de modificações aplicadas sobre a variável dependente, como a utilização do share de público, Share_Publico ${ }_{i t}$, dado pela razão entre o público de um filme e o público total de cinema no ano de exibição $t$. Destaca-se a extensão do modelo 2 representada pelas regressões explorando a heterogeneidade anual do efeito do funcionamento da Ancine, as quais consideram explicitamente a dinâmica do efeito de tratamento, algo de particular relevância tendo-se em mente o tempo médio de produção de um filme nacional e a atuação da agência de promoção do fomento. 


\subsubsection{Qual o efeito dos valores incentivados sobre a bilheteria dos filmes nacionais?}

Conforme argumentado ao fim da seção 5.1, a relação causal dos valores incentivados para a bilheteria de filmes nacionais assume que o baixo custo do capital que corresponde aos recursos subsidiados viabiliza a produção de mais obras cinematográficas e, sobretudo, eleva a sua qualidade ao contribuir com orçamentos cujos valores são compatíveis com gastos superiores com elenco, figurinos, locações, etc. Portanto, as consequentes produções de maior porte atraem mais público e se refletem em bilheterias esperadas maiores com a política de fomento.

Ao mesmo tempo, os responsáveis pela política pública que aprovam ou recusam os incentivos fiscais providos por diferentes classes de incentivadores julgam características além daquelas que podem ser controladas com as variáveis da base de dados utilizada. Principalmente, uma medida subjetiva como a "qualidade" do projeto enviado à Ancine (ou, antes dessa, ao Ministério da Cultura) extrapola a origem regional, o gênero, a produtora e o diretor. Projetos com parâmetros adequados à sua viabilidadẹ tendem a captar mais recursos e, simultaneamente, ao serem devidamente executados, tendem a ter desempenhos de bilheteria superiores.

Portanto, identificam-se possíveis canais de endogeneidade para os valores captados, sobretudo para os valores incentivados através da renúncia fiscal, mais afeitos à autoseleção e, principalmente, por corresponderem a uma proporção bastante superior do total de filmes incentivados em comparação aos demais mecanismos considerados.

3. Modelo que explica a bilheteria dos filmes nacionais: regressão da bilheteria de filmes nacionais contra os valores captados com incentivo fiscal.

O objetivo principal do modelo consiste em determinar o efeito dos valores incentivados através de renúncia fiscal sobre a receita dos filmes nacionais, logo, busca-se definir se a política de fomento de incentivo fiscal foi capaz de ampliar o acesso do consumidor brasileiro a filmes nacionais, considerando a métrica da bilheteria realizada.

A variável dependente consiste na Bilheteria $_{i t}$, enquanto que a variável explicativa principal é IncentivoFiscal ${ }_{i t}$. O conjunto de variáveis de controle é composto

1 Por exemplo, pertinência e originalidade do roteiro, aspectos técnicos e artísticos de filmagem, fotografia, etc. 


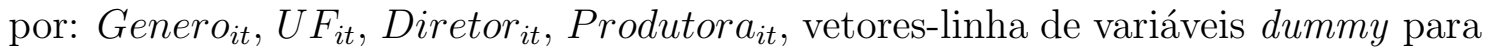
as categorias dessas características, e $\delta_{t}$, o efeito-fixo de tempo. A equação de referência, então, é dada por:

$$
\begin{gathered}
\text { Bilheteria }_{i t}=\alpha_{3}+\beta_{31} \text { IncentivoFiscal }_{i t} \\
+ \text { Genero }_{i t} \lambda_{31}+U F_{i t} \lambda_{32}+\text { Diretor }_{i t} \lambda_{33}+\text { Produtora }_{i t} \lambda_{34}+\delta_{t}+\epsilon_{3 i t}
\end{gathered}
$$

Onde $\lambda_{31}, \ldots, \lambda_{34}$ são vetores-coluna de parâmetros dos respectivos vetoreslinha de variáveis dummy. Sendo $x_{3 i t}$ o vetor de variáveis explicativas (principais e controles), para que a estimação da equação (5.3) por MQO seja consistente, devese supor que $E\left(x_{3 i t} . \epsilon_{3 i t}\right)=0$. Assim, essa hipótese de identificação pressupõe que nenhum fator não observado que afeta a renda de bilheteria de um filme pode ter correlação com: os valores incentivados, o gênero, a origem regional, o diretor, a produtora/distribuidora e o ano de exibição.

Como discutido acima, espera-se que o valor captado com incentivo fiscal por um filme tenha correlação, por exemplo, com aspectos artísticos e técnicos não mensuráveis e que afetam a sua bilheteria. Isso porque, as autoridades e, em última medida, mesmo os incentivadores, devem avaliar a viabilidade de um projeto proponente em características suas que independem da origem regional, do gênero, do período de tempo, etc.

É necessário, então, a aplicação da técnica de estimação dos Mínimos Quadrados em Dois Estágios (MQ2E), a qual utiliza de variáveis instrumentais para explorar as variações da variável explicativa de interesse que não covariam com os termos omitidos que, a um só tempo, têm correlação com a bilheteria e o incentivo fiscal. Dessa forma, é possível tratar a endogeneidade do valor captado com incentivo fiscal, obtendo-se uma estimativa consistente do parâmetro $\beta_{31}$.

Pela indisponibilidade de instrumentos para o investimento do FSA e para as outras fontes e também pela menor proporção de filmes incentivados através desses mecanismos de fomento, optou-se por excluir essas variáveis explicativas do procedimento de estimação por variáveis instrumentais. Portanto, a instrumentalização descrita a seguir se aplica apenas ao incentivo fiscal.

Um instrumento possível para o valor captado com incentivo fiscal tem correlação com essa variável, isto é, deve covariar com o valor incentivado a um filme 
via renúncia fiscal e, ao mesmo tempo, deve ser alheio ao setor de cinema, mais especificamente, deve ser independente das características do filme, sobretudo os fatores não observáveis.

A base de dados de incentivadores, utilizada previamente no capítulo 3 de descrição da política pública, contempla variáveis que dispõem dessas características pertinentes a variáveis instrumentais. Com informações entre 2007 e 2016 sobre os incentivadores dos principais mecanismos de fomento, como a Lei Rouanet e a Lei do Audiovisual, a base de incentivadores apresenta o ano de incentivo, o nome do incentivador e o valor total incentivado por mecanismo de captação.

Os valores incentivados dependem fundamentalmente da rentabilidade das empresas, caso os incentivadores consistam em pessoas jurídicas, ou das rendas das famílias, caso os incentivadores sejam pessoas físicas, pois o Imposto de Renda consiste na base tributária da dedução fiscal. Portanto, os rendimentos dos incentivadores constituem variações relacionadas às captações anuais, porém, independentes de características dos projetos.

É preciso, ainda assim, vincular tais dados a cada filme da base de variáveis de resultado, para o que se aplicam as informações da base de dados da relação de projetos, também discutida e utilizada no capítulo 3, que descreve diversas informações sobre a captação dos projetos. Como os valores para cada incentivador estão discriminados por mecanismo de incentivo, é possível interagir esses dados com a distribuição dos valores captados por um filme de acordo com os instrumentos que compuseram o seu total captado. Dessa forma, as variações exógenas concernentes aos incentivadores são conectadas às captações de cada filme por mecanismo.

Como demonstrado no capítulo 3 e em tabelas do anexo A, durante a descrição dos incentivadores, há grande concentração dos valores incentivados em um pequeno grupo de empresas, notadamente estatais. Petrobras, BNDES, Caixa Econômica Federal, Banco do Brasil, Sabesp e Eletrobrás concentram, em média, 65\%, 42\% e 40\% do total anual incentivado através dos artigos 18 da Lei Rouanet e $1^{\circ}$ e $1^{\circ} \mathrm{A}$ da Lei do Audiovisual, respectivamente, entre 2007 e 2016. Considerando todos os mecanismos de incentivo, anualmente $26 \%$ do total incentivado, em média, correspondeu a essas empresas. Apenas a Petrobras e o BNDES, por exemplo, proveram, em média, $18 \%$ do total captado com incentivo fiscal. 
Selecionam-se, então, essas seis empresas estatais para compor diferentes instrumentos, ao que se adicionam outras três categorias: demais estatais, empresas privadas e pessoas físicas. Para essas categorias não se procedeu a uma subdivisão em virtude da grande dispersão de seus incentivadores. Por exemplo, em média, anualmente elencam-se 24 distintas estatais incentivadoras, ao mesmo tempo em que são listadas 243 distintas empresas privadas e 191 pessoas físicas.

Assim, define-se um instrumento para cada uma das seguintes nove fontes de recursos: Petrobras, BNDES, Caixa, Banco do Brasil, Sabesp, Eletrobrás, outras estatais, empresas privadas e pessoas físicas. Os instrumentos construídos envolvem três fatores: a participação de um dado mecanismo $k$ no total captado no ano $s$ pelo projeto do filme $i$ exibido no ano $t\left(w_{i t}^{k s}\right)$, a participação da fonte de recurso (incentivador) $f$ no total incentivado através do mecanismo $k$ em um dado ano $s$ $\left(w^{k f s}\right)$ e uma variável de rendimento $\left(y^{f s}\right)$ que representa a base de recursos a partir da qual o incentivador define o seu valor incentivado anual.

Quanto às variáveis de rendimento, foram utilizados logaritmos naturais de variáveis específicas a cada classe de incentivador, a fim de permitir a estimativa de elasticidades. Para as empresas estatais, foi utilizado o logaritmo natural da receita anual defasada $\left(y^{f s-1}\right)$, assim, tem-se uma medida do montante de recursos do qual as estatais extraem uma parcela a ser destinada a um investimento, patrocínio ou doação a um projeto de audiovisual. A utilização do rendimento defasado expressa o fato de que as empresas consideram a sua situação recente como um indicativo da receita a ser auferida no ano corrente.

Para as demais empresas estatais, o logaritmo natural dos gastos da administração pública representa um bom indicador da evolução do setor público. Para as empresas privadas, o logaritmo natural do PIB acompanha a situação geral dos negócios para um conjunto de empresas consideravelmente diversificado em termos setoriais. Para as pessoas físicas, o logaritmo natural da renda nacional disponível bruta resume o rendimento geral disponível para consumo privado pela população brasileira. Todas essas variáveis obtidas das contas nacionais do IBGE se encontram disponíveis para a extensão temporal pertinente (2007-2016).

Define-se, então, o instrumento referente à fonte de captação $f$ através da soma 
para todos os mecanismos do produtório entre os três fatores definidos acima:

$$
z_{i t}^{f}=\sum_{k}\left[w_{i t}^{k s} \cdot\left(w^{k f s} \cdot y^{f s}\right)\right]
$$

Onde $i$ é um filme nacional exibido no ano $t$ com captação no ano $s$ através do mecanismo $k$. Além disso, $f$ corresponde a uma das nove classes de incentivador definidas acima. Portanto, a equação (5.4) representa uma repartição ad hoc do total incentivado em um dado ano por um incentivador, reproduzindo a real captação de um filme através da sua participação em cada mecanismo.

Das duas hipóteses para a validade de um instrumento, quais sejam, relevância, em termos de correlação não nula com a variável explicativa endógena, e exogeneidade, em termos de correlação nula com o termo de erro da equação de referência, a hipótese de relevância é facilmente defendida, uma vez que os valores captados por um filme partem da soma total resultante dos incentivos de cada distinto incentivador, logo, variações dessa soma produzem variações esperadas na captação de um filme individual. Inclusive, os principais incentivadores, como a Petrobras e o BNDES, seguem uma política interna de incentivo à cultura. Assim, seus orçamentos compõem uma proporção considerável dos recursos a serem distribuídos anualmente entre os projetos proponentes, de tal forma que os valores captados por esses dependem das somas totais disponibilizadas pelos grandes incentivadores.

Quanto à exogeneidade, controlando-se por choques ano-específicos, não há razão pela qual uma variação, por exemplo, na receita da Petrobras se relacione com variações na bilheteria de um filme nacional, a não ser por seus efeitos sobre os valores incentivados. A participação de uma fonte no total incentivado via mecanismo $k$ igualmente não deve ter correlação com o desempenho de um filme. Por fim, não há relação estatística ${ }^{2}$ ou prevista pela legislação entre determinados tipos de filmes e os mecanismos de captação, isto é, não há uma maior chance para que um filme busque e obtenha recursos através de um dado mecanismo em contraposição a outro.

Concluindo, o modelo se aplica apenas a produções nacionais, abrangendo filmes exibidos entre 2007 e 2016, uma vez que está disponível apenas para esse

2 Foram conduzidos testes de média entre distintos gêneros comparando a proporção de cada mecanismo no total captado por um projeto. Não se encontrou diferença estatisticamente significante entre os gêneros. 
intervalo de tempo a base de dados de incentivadores, utilizada para a construção das variáveis instrumentais. Serão aplicadas restrições amostrais, de modo a excluir outliers abaixo e/ou acima de certos percentis.

As possibilidades metodológicas são semelhantes às do modelo 2. Considerando possíveis não linearidades entre a variável dependente e as variáveis explicativas, será aplicado o logaritmo natural sobre a bilheteria.

\subsubsection{Qual o efeito dos valores incentivados sobre as receitas relativas dos filmes nacionais?}

A relação causal dessa questão a ser investigada se assemelha à da questão anterior, ou seja, um maior valor incentivado permite um orçamento superior, com o que uma produção adquire atributos que atraem um maior público e que, em particular, permitem uma maior extração de valor do consumidor, o qual se dispõe a pagar um preço médio mais elevado pelo acesso à exibição do filme.

4. Modelo que explica o preço médio do ingresso de filmes nacionais: regressão da razão entre a bilheteria e o público de um filme contra os valores captados (incentivo fiscal, investimento do FSA, outras fontes de incentivo) e contra o tratamento do início das operações da Ancine.

Os objetivos do modelo consistem em verificar se a política de fomento teve êxito em ampliar proporcionalmente ao público as receitas dos filmes nacionais e investigar o efeito do funcionamento da Ancine sobre essas receitas proporcionais.

A variável dependente é o preço médio do ingresso, $P M I_{i t}$, dado pela razão entre a bilheteria e o público de um filme. As variáveis explicativas principais são:

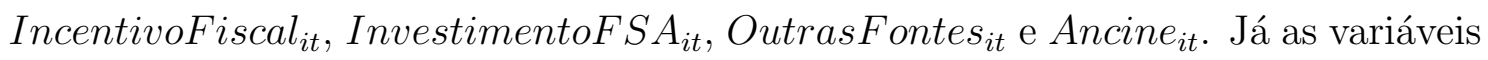
de controle são Genero $_{i t}, U F_{i t}$, Diretor ${ }_{i t}$, Produtora $_{i t}$, vetores-linha de variáveis dummy, e $\delta_{t}$, o efeito-fixo de ano. Assim, a equação de referência consiste em:

$$
P M I_{i t}=
$$

$\alpha_{4}+\beta_{41}$ IncentivoFiscal $_{i t}+\beta_{42}{\text { InvestimentoF } S A_{i t}+\beta_{43} \text { OutrasFontes }}_{i t}+\delta_{4}$ Ancine $_{i t}$

$$
+ \text { Genero }_{i t} \lambda_{41}+U F_{i t} \lambda_{42}+\text { Diretor }_{i t} \lambda_{43}+\text { Produtora }_{i t} \lambda_{44}+\delta_{t}+\epsilon_{4 i t}
$$


Novamente, $\lambda_{41}, \ldots, \lambda_{44}$ são vetores-coluna de parâmetros. A hipótese de identificação novamente consiste na ausência de correlação entre as variáveis explicativas e o termo de erro. Conforme argumentado no capítulo 6, julgou-se mais adequado não utilizar a estratégia de variáveis instrumentais para esse modelo. Também à semelhança do modelo 3, consideram-se apenas os filmes nacionais exibidos entre 1995 e 2016, não havendo restrição amostral para esse modelo. Para a estimação de elasticidades, será aplicado o logaritmo natural sobre a variável dependente.

\subsubsection{Qual o efeito dos valores incentivados sobre a qualidade dos filmes nacionais?}

Ao incrementar o orçamento e, consequentemente, o volume de recursos técnicos e artísticos mobilizados, os incentivos monetários da política de fomento permitem uma maior qualidade das obras produzidas, tal como avaliada pelo público e mensurada por um instrumento de comunicação de largo alcance no meio cinematográfico, como é o caso do site da IMDb.

5. Modelo que explica o rating dos filmes nacionais: regressão da avaliação de um filme nacional pelos usuários da IMDb contra os valores captados (incentivo fiscal, investimento do FSA, outras fontes de incentivo) e contra o tratamento do início das operações da Ancine.

Os objetivos do modelo consistem em mensurar os efeitos da política de fomento e do funcionamento da Ancine sobre a avaliação dos filmes nacionais pelo público da IMDb, sendo essa uma medida de qualidade das obras.

A variável dependente é o Rating ${ }_{i t}$, tendo por variáveis explicativas principais o IncentivoFiscal ${ }_{i t}$, o InvestimentoFS $A_{i t}$, as OutrasFontes It $_{i t}$ e a Ancine It $_{\text {. Sendo }}$ as variáveis de controle Genero $_{i t}, U F_{i t}$, Diretor ${ }_{i t}$, Produtora $a_{i t}$, vetores-linha de variáveis dummy, e $\delta_{t}$, o efeito-fixo de ano, a equação de referência é:

Rating $_{i t}=$

$\alpha_{5}+\beta_{51}$ IncentivoFiscal $_{i t}+\beta_{52}$ InvestimentoF $_{\text {In }} A_{i t}+\beta_{53}$ OutrasFontes ${ }_{i t}+\delta_{5}$ Ancine $_{i t}$

$$
+ \text { Genero }_{i t} \lambda_{51}+U F_{i t} \lambda_{52}+\text { Diretor }_{i t} \lambda_{53}+\text { Produtora }_{i t} \lambda_{54}+\delta_{t}+\epsilon_{5 i t}
$$


Onde $\lambda_{51}, \ldots, \lambda_{54}$ são vetores-coluna de parâmetros. Dado $x_{5 i t}$ o vetor de variáveis explicativas, a hipótese de identificação é representada por $E\left(x_{5 i t} \cdot \epsilon_{5 i t}\right)=0$. Conforme argumentado no capítulo 6, julgou-se mais adequado não utilizar a estratégia de variáveis instrumentais para esse modelo. O modelo se aplica ao conjunto de filmes nacionais exibidos entre 1995 e 2016. Assim como para o modelo 4, será aplicado o logaritmo natural sobre a variável dependente.

\subsection{Intenção revelada da política pública: estímulo ao gênero de documentários}

A seção anterior parte de questões a serem investigadas que consideram os objetivos declarados da política pública. Conforme argumentado no capítulo 3 e exposto no capítulo 4, houve uma atenção especial dos gestores da política sobre o gênero de documentários, ainda que a legislação não apresente qualquer intenção gênero-específica. Assim, merece uma seção específica a investigação quanto ao cumprimento desse objetivo não declarado.

Uma interpretação imediata para essa intenção revelada consiste em um objetivo da política pública de promover um gênero com grande potencial artístico e informacional e que, ao mesmo tempo, não dispõe de apelo comercial suficiente para que o setor privado seja capaz de produzir uma quantidade mais próxima da socialmente ótima, levando-se em conta os seus efeitos sobre o senso crítico e estético da própria classe artística e do público em geral.

Dessa forma, a eficácia da correção dessa externalidade positiva pode ser auferida através da mensuração do impacto da política pública sobre a avaliação pelo público dos documentários nacionais produzidos, considerando que essa avaliação reflita a capacidade de um filme de influenciar as opiniões ou convicções de seu público. Para tanto, é concebido um modelo cuja variável de resultado consista no rating dos documentários nacionais.

Com relação à quantidade de documentários produzidos, o capítulo 4 apresentou o forte crescimento, no pós-Ancine, do número de documentários exibidos, que passou de 37, entre 1995 e 2003, para 423, entre 2004 e 2016. Ainda mais relevante é o forte crescimento da proporção de documentários nacionais exibidos, que passou, no pós-2004, de $17 \%$ para $37 \%$ do total de filmes nacionais exibidos. Um modelo que explica a probabilidade de um filme nacional exibido ser um documentário, a partir de uma variável dummy indicando 
o período de funcionamento da Ancine, pode contribuir para demonstrar a expansão da oferta desse gênero, na medida em que características dos filmes sejam controladas por meio dos métodos de estimação.

Com o primeiro objetivo, então, de corroborar a expansão da oferta de documentários nacionais, no pós-Ancine, um modelo semelhante ao modelo 1 pode ser proposto, tendo como variável dependente a dummy Documentario ${ }_{i t}$, que iguala 1 se o filme $i$ exibido no ano $t$ for um documentário e 0, caso contrário. A variável explicativa principal, assim, consiste na dummy Ancine ${ }_{i t}$, distinguindo o período de funcionamento da agência. As variáveis de controle disponíveis consistem: nos valores incentivados e nas dummies para ano, origem regional, produtora e diretor. A seguinte equação resume essa proposta metodológica:

$$
\begin{gathered}
\text { Documentario }_{i t}=\alpha_{6}+\beta_{61} \text { Ancine }_{i t}+\gamma_{61} \text { IncentivoFiscal }_{i t}+\gamma_{62} \text { InvestimentoF }_{\text {it }} \\
+\gamma_{63} \text { OutrasFontes }_{i t}+U F_{i t} \lambda_{61}+\text { Produtor }_{i t} \lambda_{62}+\text { Diretor }_{i t} \lambda_{63}+\delta_{t}+\epsilon_{6 i t}
\end{gathered}
$$

Dado o vetor $x_{6 i t}$ composto pelas variáveis explicativas do modelo de probabilidade linear da equação (5.7), supõe-se que $E\left(x_{6 i t} . \epsilon_{6 i t}\right)=0$. A partir dessa hipótese de identificação, a estimação do efeito do funcionamento da Ancine sobre a proporção de documentários nacionais exibidos considera a amostra completa de filmes nacionais exibidos no país entre 1995 e 2016.

Verificada, empiricamente, a expansão da oferta de documentários, no pós-Ancine, cabe investigar os impactos da política pública sobre a qualidade dos documentários nacionais. Assumindo que a qualidade de um documentário reflita, para esse gênero específico, a sua capacidade de impactar o senso crítico e estético do público, a partir do que se configuram aplicações educativas, políticas e artísticas do seu consumo, a possível motivação, para o objetivo revelado de promoção de documentários, da correção da externalidade positiva decorrente da exibição desse gênero pode ter seu êxito mensurado através da proposta metodológica do modelo 5 .

Com efeito, a pertinência da variável do rating para o gênero de documentários é constatada pela consideravelmente baixa média de público do gênero (10.461 pessoas frente a uma média geral de 212.521, considerando apenas filmes nacionais) em paralelo a uma avaliação do público com a maior média por gênero (7,3 frente a uma média geral de 6,4, considerando apenas filmes nacionais). Assim, define-se a seguinte equação tendo por 
variável dependente o Rating $_{i t}$, por variáveis explicativas principais o IncentivoFiscal $_{i t}$, as OutrasFontes $i t$, o InvestimentoFS $A_{i t}$ e Ancine $_{i t}$ e por controles as variáveis dummy para ano, origem regional, produtora, diretor e qualificativo de gênero, esse que distingue entre as principais temáticas de um documentário (música, esporte e biografia):

$$
\begin{gathered}
\text { Rating }_{i t}= \\
\alpha_{7}+\beta_{71} \text { IncentivoFiscal }_{i t}+\beta_{72} \text { InvestimentoF }_{\text {In }}+\beta_{73} \text { OutrasFontes }_{i t}+\delta_{7} \text { Ancine }_{i t} \\
+ \text { Qualif }_{i t} \lambda_{71}+U F_{i t} \lambda_{72}+\text { Diretor }_{i t} \lambda_{73}+\text { Produtora }_{i t} \lambda_{74}+\delta_{t}+\epsilon_{7 i t}
\end{gathered}
$$

A hipótese de identificação para a equação (5.8D consiste em $E\left(x_{7 i t} \cdot \epsilon_{7 i t}\right)=0$, onde $x_{7 i t}$ é o vetor de variáveis explicativas. Também aqui, julgou-se mais adequado não utilizar a estratégia de variáveis instrumentais para a estimação. O modelo se aplica à totalidade de documentários nacionais exibidos entre 1995 e 2016.

\subsection{Conclusão}

Os modelos listados acima representam a base metodológica das respostas que se desejam alcançar para as questões que resumem a avaliação da política pública de cinema no Brasil, a qual consiste no objetivo principal da pesquisa. No capítulo seguinte, a metodologia será combinada à base de dados consolidada e serão exploradas as possibilidades metodológicas a fim de se refinar as respostas encontradas. 


\section{Resultados}

O capítulo de resultados se espelha no capítulo de metodologia, na medida em que são expostas as questões investigadas e revisados os modelos. Adicionalmente, há comentários quanto aos procedimentos de estimação e, na sequência, são apresentadas as tabelas e figuras com os parâmetros estimados, a partir do que seguem as devidas interpretações. Por fim, citam-se os resultados de eventuais extensões dos modelos e estabelecem-se as respostas apropriadas às questões investigadas.

\subsection{A Ancine impactou a proporção de filmes nacionais exibidos?}

Foram regredidas três classes de modelos: modelo de probabilidade linear (MPL), Probit e Logit. Devido à semelhança dos efeitos parciais médios estimados, são apresentados os resultados do modelo de probabilidade linear, em decorrência, sobretudo, de os parâmetros estimados consistirem no efeito parcial médio. Além disso, foram incluídas interações entre as origens dos filmes e os anos de exibição, visando controlar pela tendência de exibição de origens específicas. Novamente, pela semelhança dos parâmetros estimados, são apresentados os resultados sem os termos de interação.

A tabela|6.1 abaixo sugere que a agência não foi capaz de elevar a proporção de filmes nacionais exibidos, uma vez que o efeito do período pós-Ancine indica uma probabilidade 7,2 pontos percentuais inferior de que um filme exibido seja nacional. As colunas 2 e 3 da tabela decompõem a definição de filme internacional.

Percebe-se que a queda significante a um nível de 5\% na proporção de filmes nacionais exibidos se deve à maior proporção de exibição do que se definiu como sendo filmes de "origens similares" ao Brasil. Tratam-se de origens cujo índice de convencionalidade definido no capítulo 4 é muito próximo ao valor da média brasileira: Europa Ocidental, Sudeste Asiático e Oceania. A comparação de filmes nacionais com essas categorias de origem revela que a probabilidade de exibição de um filme nacional se reduziu em quase 20 pontos percentuais no pós-Ancine.

A figura 6.1 apresenta os parâmetros estimados no pós-Ancine para cada ano separadamente entre 2004-2016, tanto para o modelo que contrapõe a exibição de filmes 
Tabela 6.1 - Estimação do modelo que explica a probabilidade de um filme exibido ser nacional

\begin{tabular}{lccc}
\hline $\begin{array}{l}\text { Variável dependente: } \\
\text { Nacional }\end{array}$ & $(1)$ & $(2)$ & $(3)$ \\
& NacionalxInternacional & NacionalxEUA & NacionalxSimilares \\
\hline Ancine & $-0,0720^{* *}$ & $-0,0764^{* *}$ & $-0,180^{* * *}$ \\
& $(0,0280)$ & $(0,0344)$ & $(0,0541)$ \\
\hline Dummies de ano & Sim & Sim & Sim \\
Dummies de gênero & Sim & Sim & Sim \\
\hline Observações & 4.967 & 3.397 & 2.384 \\
Previsão correta & $80,89 \%$ & $80,07 \%$ & $70,81 \%$ \\
\hline
\end{tabular}

Erros padrão robustos entre parênteses.

*** $p<0,01,{ }^{* *} p<0,05,{ }^{*} p<0,1$.

Filmes exibidos entre 2001 e 2016. Filmes nacionais: 1.267.

nacionais com filmes norte-americanos quanto para o modelo que contrapõe produções nacionais com produções de origens similares ao Brasil.

O efeito de queda na probabilidade de exibição de um filme nacional diminui ao longo do período pós-Ancine, demonstrando que progressivamente a escolha de exibição do cinema nacional tendeu a se fortalecer. Inclusive, embora não significante (à exceção do ano de 2013, em que há significância de 10\%), os anos a partir de 2012 apresentaram uma probabilidade de exibição de filmes nacionais superior frente à de exibição de filmes norte-americanos.

Em resumo, como o período pós-Ancine apresenta uma probabilidade de exibição de filmes nacionais inferior à de exibição de filmes internacionais, na comparação com o período prévio ao funcionamento da agência, conclui-se que essa não pode ter impactado positivamente essa variável de resultado, isto é, a Ancine não ampliou a proporção de filmes nacionais exibidos no país. Mais especificamente, encontra-se que a proporção nacional exibida se reduz frente à proporção de filmes de origens como a Europa Ocidental, o Sudeste Asiático e a Oceania, com o que se conclui que houve, no período de funcionamento da Ancine, uma diversificação regional da exibição. 
Figura 6.1 - Efeitos parciais médios do período de funcionamento da Ancine sobre a probabilidade de um filme exibido ser nacional
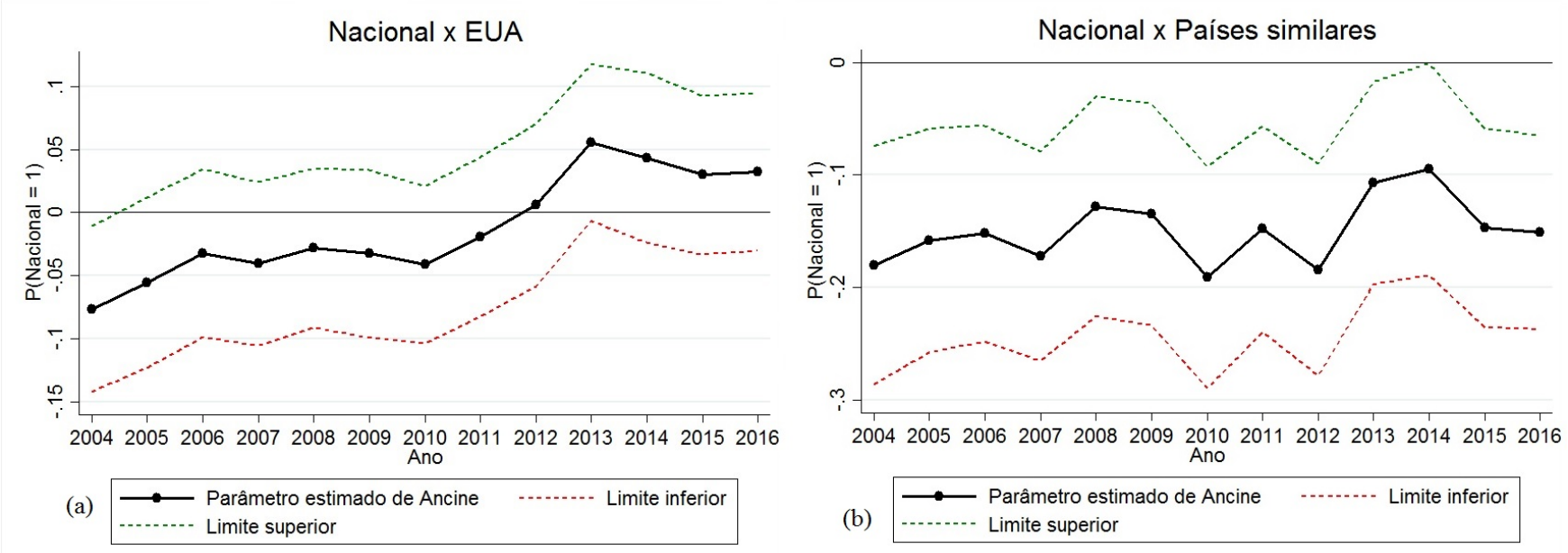

Filmes exibidos entre 2001 e 2016.

Filmes nacionais: 1.267. Filmes internacionais: 3.247 .

Intervalos de confiança de $95 \%$

\subsection{O funcionamento da Ancine impactou o público de filmes na- cionais frente ao de internacionais?}

Como definido no capítulo anterior, o modelo pertinente consiste em um modelo de diferenças-em-diferenças. Ao estimar a diferença entre as diferenças de público médio no pós e no pré-Ancine para os grupos de tratamento (filmes nacionais) e de controle (filmes internacionais), controlando-se para diversas características dos filmes exibidos, busca-se avaliar o impacto comparativo do funcionamento da agência sobre o público dos filmes nacionais, métrica final do acesso do consumidor brasileiro ao produto nacional.

As origens para as quais se aplica o modelo são todas as dez categorias definidas anteriormente, enquanto que a extensão temporal corresponde ao intervalo 2001-2016. Além da estimação para a amostra completa, foram desconsiderados os outliers de acordo com os seguintes critérios: público superior ao percentil de $99 \%$ e público superior ao percentil de $90 \%$. Isso corresponde a subtrair 73 (1,5\%) e 518 (11\%) observações da amostra completa, respectivamente. Esses procedimentos de tratamento de outliers se justificam pela recorrente existência de recordes de público que se concentram em um pequeno conjunto de produções $\mathrm{s}^{1}$

1 Julgou-se mais adequado excluir apenas os outliers que divergem acima de percentis superiores, uma vez que as observações abaixo de percentis inferiores correspondem a um conjunto considerável de 
A perspectiva de uma não linearidade da relação entre os outcomes e as explicativas justifica que se considere o modelo com variável dependente em logaritmo natural como a especificação de referência. Conforme disposto na tabela 6.2 , o parâmetro estimado de 0,169 implica ${ }^{2}$ no aumento estimado de 18,4 pontos percentuais no público esperado de filmes nacionais em comparação ao de filmes internacionais, no pós-Ancine, para a amostra completa, o qual, porém, não se mostra significante, resultado semelhante àqueles correspondentes às amostras restritas abaixo dos percentis de $99 \%$ e de 90\%. A tabela 6.2 indica, portanto, que a Ancine não foi capaz de elevar o público esperado de um filme nacional quando comparado ao público esperado de um filme internacional, isto é, não existe o efeito do tratamento da Ancine sobre o público de filmes nacionais.

Tabela 6.2 - Estimação do modelo de diferenças-em-diferenças

\begin{tabular}{lccc}
\hline Variável dependente: & $(1)$ & $(2)$ & $(3)$ \\
$\ln ($ Publico $)$ & Amostra completa & Abaixo de p99 & Abaixo de p90 \\
\hline Nacional & $-2,969^{* * *}$ & $-2,943^{* * *}$ & $-2,923^{* * *}$ \\
& $(0,242)$ & $(0,241)$ & $(0,248)$ \\
Ancine & $-1,083^{* * *}$ & $-1,038^{* * *}$ & $-1,155^{* * *}$ \\
& $(0,176)$ & $(0,175)$ & $(0,195)$ \\
Nacional*Ancine & 0,169 & 0,17 & 0,263 \\
& $(0,214)$ & $(0,213)$ & $(0,222)$ \\
Controles & Sim & Sim & Sim \\
\hline Observações & 4.818 & 4.770 & 4.327 \\
R-quadrado & 0,544 & 0,537 & 0,471 \\
\hline
\end{tabular}

Erros padrão robustos entre parênteses.

*** $p<0,01,{ }^{* *} p<0,05,{ }^{*} p<0,1$.

Filmes exibidos entre 2001 e 2016.

Controles: valores incentivados, gênero, ano, origem, origem regional, produtora, diretor.

Observa-se também que os tratamentos em que consistem os valores incentivados, no que toca à renúncia fiscal e ao investimento do FSA, foram eficazes em ampliar o público dos filmes nacionais, exclusivamente aqueles que podem receber esses recurso\$3 Por fim, os parâmetros negativos das variáveis dummy referentes à origem nacional de

filmes, cuja exclusão pode conduzir a resultados equivocados.

2 Sendo $\delta$ o parâmetro da variável dummy $D$ no modelo que explica as variações na variável dependente $y$ em logaritmo natural, $\ln y$, o efeito de $D$ sobre $y$ é de $\left(e^{\delta}-1\right) * 100$ pontos percentuais.

3 Como o início do funcionamento da Ancine corresponde ao ano de 2004 e os instrumentos utilizados para a estimação do modelo 3 por variáveis instrumentais estão disponíveis apenas a partir de 2007, não foi possível a utilização dessa técnica nesse modelo. Adicionalmente, entendeu-se mais apropriada a inclusão de tais variáveis de valor incentivado, mesmo que seu efeito estimado sobre o público deva ser viesado. Pela correlação entre essas variáveis e a dummy Nacional, a variável de tratamento de interesse (interação entre Nacional e Ancine) seria endógena no caso da sua omissão. 
um filme e ao seu ano de exibição ser pós-2004 decorrem, respectivamente, da predileção do consumidor típico com relação às obras internacionais e da tendência de diminuição do público médio com a diversificação das formas de acesso ao conteúdo audiovisual.

Uma importante extensão explorada consiste na variável do share de público, que consiste na razão de cada público com o total anual. Conforme exposto na tabela 6.3 abaixo, para as três definições amostrais, há um efeito de tratamento significativo sobre a participação do público de um filme no total. Para a amostra completa, o pós-Ancine implica em uma participação no total 0,5 ponto percentual superior para filmes nacionais em comparação a internacionais. Portanto, com a agência, um filme brasileiro médio ganhou participação no total de público frente às demais categorias de origem.

Tabela 6.3 - Estimação do modelo de diferenças-em-diferenças

\begin{tabular}{lccc}
\hline Variável dependente: & $(1)$ & $(2)$ & $(3)$ \\
Share_Publico & Amostra completa & Abaixo de p99 & Abaixo de p90 \\
\hline Nacional & $-0,00620^{* * *}$ & $-0,00525^{* * *}$ & $-0,00476^{* * *}$ \\
& $(0,00148)$ & $(0,00136)$ & $(0,000464)$ \\
Ancine & $-0,00945^{* * *}$ & $-0,0101^{* * *}$ & $-0,00660^{* * *}$ \\
& $(0,00132)$ & $(0,00129)$ & $(0,000507)$ \\
Nacional*Ancine & $0,00512^{* * *}$ & $0,00452^{* * *}$ & $0,00417^{* * *}$ \\
& $(0,00145)$ & $(0,00132)$ & $(0,000453)$ \\
Controles & Sim & Sim & Sim \\
\hline Observações & 4.818 & 4.770 & 4.327 \\
R-quadrado & 0.320 & 0.362 & 0.449 \\
\hline
\end{tabular}

Erros padrão robustos entre parênteses.

*** $p<0,01,{ }^{* *} p<0,05,{ }^{*} p<0,1$.

Filmes exibidos entre 2001 e 2016.

Controles: valores incentivados, gênero, ano, origem, origem regional, produtora, diretor.

Uma vez que o principal resultado da estimação de diferenças-em-diferenças decorre da extensão da variável do público em que consiste a participação de cada filme no total do público anual, o share de público, aplica-se a essa variável a estimação de efeitos de tratamento heterogêneos anualmente. O efeito positivo do funcionamento da Ancine sobre a diferença entre a participação esperada de um filme nacional no total de público e a participação esperada de um filme internacional, obtido através da amostra completa e exposto na coluna 1 da tabela 6.3 , é decomposto anualmente para o período 2002-2016. Assim, observa-se a evolução do tratamento no pós-2004, sendo que, para os anos préfuncionamento da Ancine, isto é, 2002 e 2003, espera-se por parâmetros próximos a zero e não significativos. 
Figura 6.2 - Parâmetros de tratamento anuais para o modelo do share de público

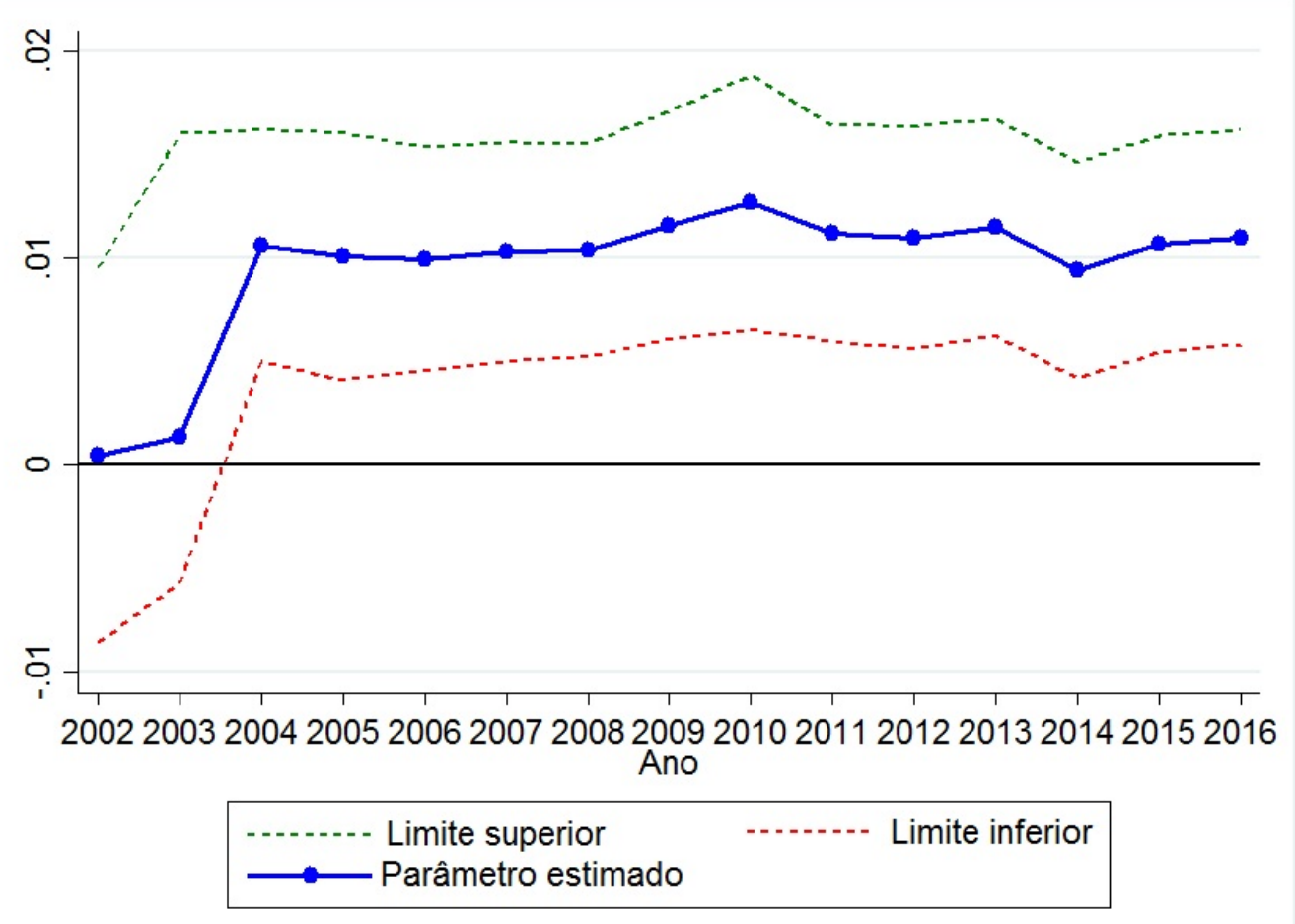

Filmes exibidos entre 2001 e 2016.

Especificação equivalente à da coluna 1 da tabela 6.3 .

Intervalo de confiança de $99 \%$.

A figura 6.2 confirma a ausência de um efeito de antecipação, na medida em que os parâmetros para os anos pré-tratamento de 2002 e de 2003 assumem valores próximos a zero e não são significativos ao nível de 1\%. Quanto ao período 2004-2016, todos os parâmetros correspondentes são significativos e apresentam-se relativamente estáveis, em torno do valor de 0,01 , indicando que, em média, no período, um filme nacional tem uma participação no total de público 1 ponto percentual superior, no pós-Ancine, comparativamente à participação de um filme internacional. Concluindo, a figura 6.3 reproduz o experimento a partir do modelo para o logaritmo natural do público.

Em resumo, partindo da especificação de referência (logaritmo natural do público), há um efeito positivo, porém, não significativo do funcionamento da Ancine sobre o público de filmes nacionais, comparativamente ao de filmes internacionais, isso para as três definições amostrais consideradas. Os parâmetros de diferenças-em-diferenças correspondem, respectivamente, a aumentos no público de 18,4, 18,5 e 30,1 pontos percentuais 4 Portanto,

4 Considerando-se o cálculo do efeito parcial de uma variável dummy sobre o logaritmo natural de uma variável dependente de interesse: $\left(e^{\delta}-1\right) * 100$, onde $\delta$ é o parâmetro da variável dummy. 
Figura 6.3 - Parâmetros de tratamento anuais para o modelo de $\ln ($ Publico $)$

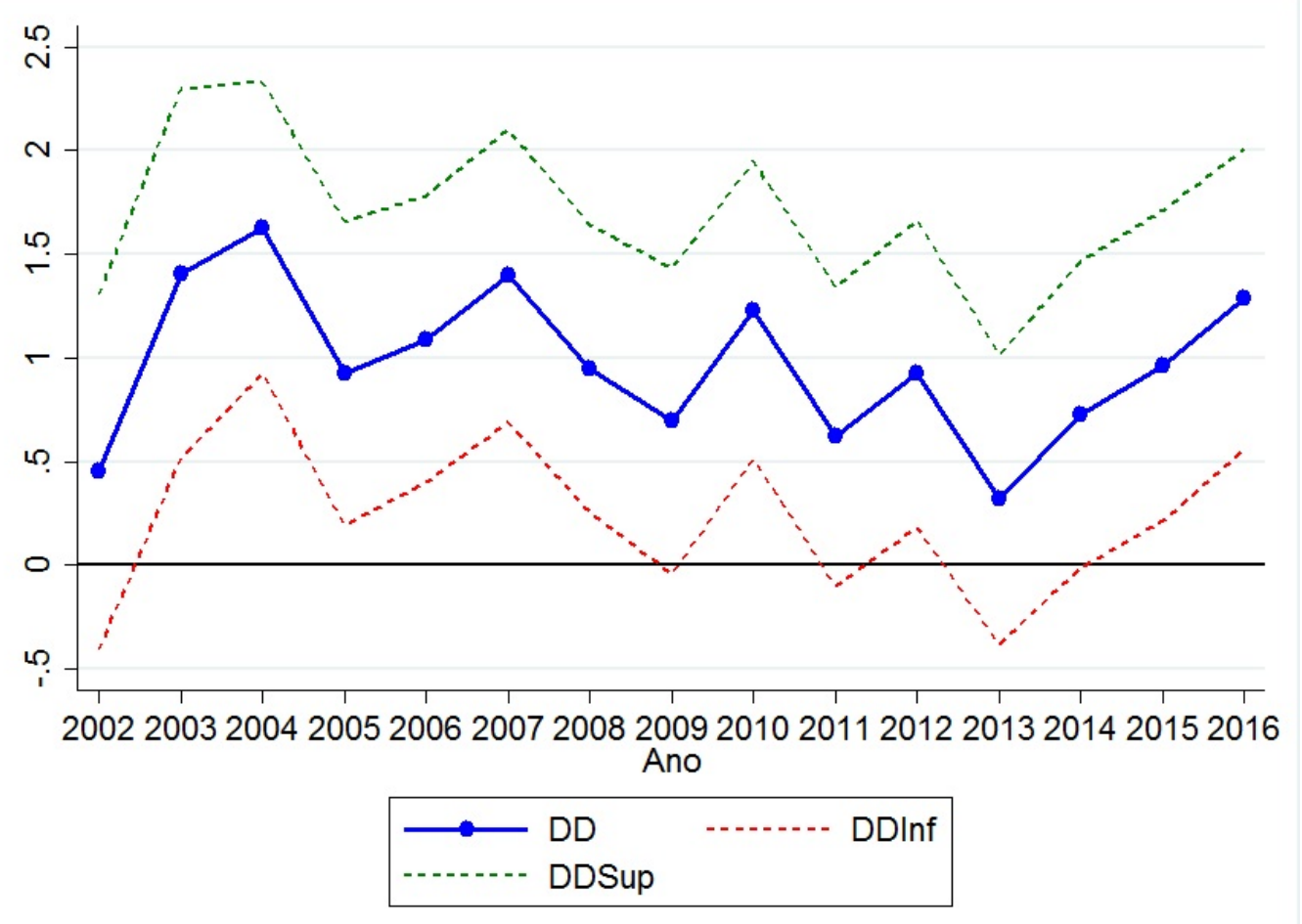

Filmes exibidos entre 2001 e 2016.

Especificação equivalente à da coluna 3 da tabela 6.2 .

Intervalo de confiança de $99 \%$.

conclui-se que a Ancine não impactou o público de filmes nacionais quando comparado ao de filmes internacionais. Além disso, encontraram-se evidências, para as três definições amostrais, de que a Ancine ampliou a participação esperada dos filmes nacionais no total de público e na comparação com os filmes internacionais.

\subsection{Qual o efeito dos valores incentivados sobre a bilheteria dos filmes nacionais?}

O modelo pertinente para o cálculo dessa elasticidade consiste na regressão dos valores arrecadados em bilheteria contra os valores captados por um filme, utilizando-se, para tanto, da estimação por variáveis instrumentais (MQ2E), descrita no capítulo 5, a qual explora as variações exógenas nos rendimentos dos incentivadores para identificar o efeito dos valores captados por um filme sobre sua renda de bilheteria. As estimações conside- 
ram apenas filmes nacionais, por ser a origem para a qual se aplica a política de fomento. A extensão temporal dos dados utilizados nas estimações é dada pelo intervalo de 2007 a 2016.

Novamente, foram desconsiderados os outliers de acordo com o seguinte critério: bilheteria superior ao percentil de $99 \%$. Por conta da relativa semelhança entre os resultados com essa definição amostral, com a amostra completa e com a amostra de observações abaixo do percentil de $90 \%$, os resultados expostos abaixo seguem apenas o primeiro critério de restrição amostral. Assim como para a estimação anterior, a perspectiva de uma não linearidade da relação entre os outcomes e as explicativas justifica que se considere o modelo com variável dependente em logaritmo natural como a especificação de referência.

A expressão para os instrumentos a serem utilizados, exposta no capítulo 5, requer dados de rendimentos dos incentivadores. O gráfico 11.1 em anexo ilustra as variações do lucro líquido e da receita das três principais incentivadoras estatais. A partir de 2012, Petrobras, BNDES e Banco do Brasil enfrentam fortes quedas na sua rentabilidade, em decorrência da crise econômica brasileira do período, bem como por conta de dificuldades internas de cada empresa. Essas variações exógenas ao mercado de cinema consistem na motivação principal dessa construção de variáveis instrumentais.

A tabela 11.1 do anexo apresenta estatísticas para os instrumentos utilizados nas regressões cujos resultados são expostos abaixo. Para as estatais, utilizou-se da definição apresentada no capítulo anterior, onde a variável de rendimento consiste no logaritmo natural da receita defasada, enquanto que, para as demais classes de incentivadores, partiu-se do logaritmo natural dos seus respectivos rendimentos contemporâneos. Destacam-se os relativamente elevados coeficientes de variação, sugerindo que as variáveis criadas dispõem de variação suficiente para serem usadas como instrumentos.

As estimações de MQ2E partiram da subamostra correspondente ao período 20072016, uma vez que a base de incentivadores limita-se apenas a esse intervalo de tempo. As estimações de MQO, por coerência, utilizaram também dessa subamostra da base completa de filmes nacionais, abrangendo o mesmo período de 2007-2016.

Quanto aos instrumentos utilizados, dos maiores incentivadores, foram selecionados os instrumentos construídos a partir do logaritmo natural da receita defasada da Petrobras, do BNDES e do Banco do Brasil. Como a inclusão dos instrumentos referentes à 
Caixa, à Sabesp e à Eletrobrás conduzia, através do teste de restrições sobreidentificadoras, à rejeição da hipótese nula de instrumentos exógenos, esses instrumentos não foram considerados nas estimações.

Também fazem parte do conjunto de instrumentos utilizados os logaritmos naturais dos gastos da administração pública, do PIB e da renda nacional disponível bruta, referentes, respectivamente, às demais empresas estatais, às empresas privadas e às pessoas físicas. Dois conjuntos de alternativas às estimações realizadas implicam em evidências de robustez aos resultados apresentados abaixo. A elasticidade estimada da bilheteria de filmes nacionais com relação à captação de incentivo fiscal mostrou-se semelhante àquela exposta a seguir considerando-se os seguintes rendimentos de estatais a partir do que os seus instrumentos foram construídos: lucro líquido, margem líquida e receita contemporâneas e defasadas, logaritmo natural da receita contemporânea e defasada, variação da receita e logaritmo natural da variação contemporâneos e defasados. Da mesma forma, para os instrumentos das demais estatais, das empresas privadas e das pessoas físicas, tanto o logaritmo natural contemporâneo e defasado, quanto a variação e o logaritmo natural da variação contemporâneos e defasados dos seus respectivos rendimentos implicam em resultados muito próximos aos apresentados abaixo.

A primeira hipótese necessária para que um conjunto de variáveis represente um adequado conjunto de instrumentos para uma variável explicativa potencialmente endógena consiste na hipótese de relevância dos instrumentos, pela qual esses devem apresentar correlação não nula com a variável explicativa original. O específico sinal dessa correlação, no presente contexto em que os instrumentos seguem a definição apresentada no capítulo 5, deve ser positivo. Maiores rendimentos para os incentivadores implicam em valores incentivados esperados superiores, logo, há um crescimento também no valor captado esperado por um filme.

O teste da hipótese de relevância dos instrumentos envolve a regressão do valor captado com incentivo fiscal, mais precisamente, seu logaritmo natural, contra os candidatos a instrumento e as demais variáveis explicativas do modelo principal (dummies de ano, gênero, origem regional, grande produtora e diretor experiente). A tabela 6.4 abaixo apresenta o resultado dessa regressão de primeiro estágio. A coluna 1 considera apenas o conjunto de estatais (Petrobras, BNDES, Banco do Brasil e demais estatais), enquanto que as colunas 2 e 3 consideram empresas privadas e pessoas físicas, respectivamente. A 
coluna 4, por sua vez, inclui os 6 instrumentos utilizados no segundo estágio.

Como argumentado acima, o sinal esperado para o parâmetro estimado dos instrumentos é positivo, o que de fato se verifica para as quatro colunas da tabela 6.4 . O mais importante, ainda assim, consiste no teste de significância conjunta, o qual verifica a força dos instrumentos ao explicar as variações da variável explicativa potencialmente endógena do modelo de referência. Para todas as regressões apresentadas nas quatro colunas da tabela 6.4 , a estatística $\mathrm{F}$ do teste de significância conjunta é consideravelmente elevada e implica na rejeição, para qualquer nível de significância assumido, da hipótese nula de que os parâmetros dos instrumentos são todos iguais a zero na equação que explica as variações do incentivo fiscal. Portanto, há evidências de que os instrumentos considerados, na coluna 4, em sua totalidade, são relevantes para explorar (exogenamente) as variações do valor captado por um filme com incentivo fiscal. 
Tabela 6.4 - Estimação de VI do modelo que explica a bilheteria de filmes nacionais Primeiro estágio

\begin{tabular}{|c|c|c|c|c|}
\hline $\begin{array}{l}\text { Variável dependente: } \\
\text { ln(IncentivoFiscal) }\end{array}$ & $\begin{array}{c}(1) \\
\text { Estatais }\end{array}$ & $\begin{array}{c}(2) \\
\text { Privado }\end{array}$ & $\begin{array}{l}(3) \\
\mathrm{PF}\end{array}$ & $\begin{array}{c}(4) \\
\text { Estatais+Privado }+\mathrm{PF}\end{array}$ \\
\hline Petrobras $^{\dagger}$ & $\begin{array}{c}4,425^{* * *} \\
(0,373)\end{array}$ & & & $\begin{array}{c}3,128^{* * *} \\
(0,364)\end{array}$ \\
\hline $\mathrm{BNDES}^{\dagger}$ & $\begin{array}{c}9,017^{* * *} \\
(1,968)\end{array}$ & & & $\begin{array}{c}6,460 * * * \\
(1,463)\end{array}$ \\
\hline Banco do Brasil ${ }^{\dagger}$ & $\begin{array}{c}3,115 \\
(3,282)\end{array}$ & & & $\begin{array}{c}3,551 \\
(2,391)\end{array}$ \\
\hline Outras Estatais ${ }^{\ddagger}$ & $\begin{array}{c}0,102 \\
(0,752)\end{array}$ & & & $\begin{array}{c}1,205 \\
(0,939)\end{array}$ \\
\hline Privado $\ddagger$ & & $\begin{array}{l}1,013^{* * *} \\
(0,0848)\end{array}$ & & $\begin{array}{c}0,618^{* * *} \\
(0,0669)\end{array}$ \\
\hline $\mathrm{PF}^{\ddagger}$ & & & $\begin{array}{c}24,77^{* * *} \\
(3,241)\end{array}$ & $\begin{array}{l}6,293^{*} \\
(3,679)\end{array}$ \\
\hline Controles & Sim & Sim & Sim & Sim \\
\hline $\begin{array}{l}\text { Estatística do teste de } \\
\text { sign. conjunta }\end{array}$ & $54,22^{* * *}$ & $142,78^{* * *}$ & $58,43^{* * *}$ & $46,77^{* * *}$ \\
\hline Observações & 425 & 425 & 425 & 425 \\
\hline R-quadrado & 0,505 & 0,489 & 0,325 & 0,564 \\
\hline
\end{tabular}

Erros padrão robustos entre parênteses.

*** $p<0,01,{ }^{* *} p<0,05,{ }^{*} p<0,1$.

Filmes exibidos entre 2007 e 2016.

Controles: gênero, ano, origem regional, produtora, diretor.

${ }^{\dagger}$ Instrumentos construídos a partir do logaritmo natural da receita defasada.

‡ Instrumentos construídos a partir do logaritmo natural dos rendimentos contemporâneos.

A partir dos valores preditos para o incentivo fiscal, construídos por meio dos parâmetros estimados no primeiro estágio e apresentados na coluna 4 da tabela 6.4 , regride-se o segundo estágio do método de MQ2E, com o que se obtém uma estimativa para a elasticidade da bilheteria de um filme com relação ao seu incentivo fiscal. A coluna 3 da tabela 6.5 apresenta o resultado dessa utilização de variáveis instrumentais, enquanto que as colunas 1 e 2 são concernentes ao método de MQO. As regressões cujos resultados estão expostos nas colunas 2 e 3 incluem controles para ano, gênero, origem regional, grande produtora e diretor experiente.

As três estimativas de elasticidade indicam uma bilheteria esperada de filmes nacionais inelástica com relação ao valor captado com incentivo fiscal, dado que os parâmetros estimados para esse mecanismo de fomento são inferiores à unidade nas três especificações das colunas 1-3. A coluna 1, por exemplo, sugere que, elevando em um ponto percentual 
Tabela 6.5 - Estimação de VI do modelo que explica a bilheteria de filmes nacionais Segundo estágio

\begin{tabular}{lccc}
\hline $\begin{array}{l}\text { Variável dependente: } \\
\ln (\text { Bilheteria) }\end{array}$ & MQO & MQO & MQ2E \\
\hline $\ln ($ IncentivoFiscal) & $0,163^{* * *}$ & $0,0788^{* * *}$ & $0,0518^{* *}$ \\
& $(0,0156)$ & $(0,0155)$ & $(0,0225)$ \\
Controles & Não & Sim & Sim \\
\hline Teste de restr. sobr. (p-valor) & - & - & 0,1170 \\
Teste de endogeneidade (p-valor) & - & - & 0,0437 \\
Observações & 514 & 514 & 425 \\
R-quadrado & 0,135 & 0,528 & 0,543 \\
\hline
\end{tabular}

Erros padrão robustos entre parênteses.

*** $p<0,01,{ }^{* *} p<0,05, * p<0,1$.

Filmes exibidos entre 2007 e 2016 .

Controles: gênero, ano, origem regional, produtora, diretor.

a captação de incentivo fiscal por um filme nacional, a sua renda de bilheteria esperada se eleva em 0,16 ponto percentual, efeito significativo ao nível de 1\%. Controlando-se por todas as características observáveis de um filme, observa-se que a elasticidade estimada se reduz à metade, embora mantenha a sua significância: um aumento de um ponto percentual no incentivo fiscal a um filme eleva a sua renda de bilheteria esperada em 0,08 ponto percentual, dado o ano de exibição, o gênero, a origem regional, a produtora e o diretor do filme.

A possibilidade de que características não observáveis de um filme, sobretudo aquelas pertinentes ao projeto proponente de recursos, tenham correlação também com a sua captação de incentivo fiscal, além da correlação com a bilheteria, justifica a aplicação da técnica de estimação de variáveis instrumentais. A coluna 3 da tabela 6.5 considera, na estimação de MQ2E, os seis instrumentos utilizados no primeiro estágio e indicados na coluna 4 da tabela 6.4 . O parâmetro estimado da elasticidade da bilheteria com relação ao valor captado com incentivo fiscal é de 0,05, inferior aos parâmetros de MQO sem e com controles e significativo ao nível de 5\%. O viés das estimativas de MQO, indicado pela estimativa de MQ2E, é coerente com a argumentação de endogeneidade apresentada no capítulo 5. Assim, a melhor estimativa disponível revela que um aumento de um ponto percentual no incentivo fiscal a um filme eleva a sua renda de bilheteria esperada em 0,05 ponto percentual.

O estimador de MQ2E apresentado acima apenas consiste em uma estimativa consis- 
tente se, além da validade da hipótese de relevância dos instrumentos utilizados, verificada anteriormente, também a hipótese de exogeneidade for satisfeita. Um modo imediato de testar essa hipótese é dado pelo teste de restrições sobreidentificadoras, disponível quando mais de um instrumento for utilizado. A coluna 3 da tabela 6.5 revela um p-valor de 0,12 sob a hipótese nula de que o conjunto de instrumentos é exógeno. Portanto, para qualquer nível de significância convencionalmente assumido, não se rejeita essa hipótese e é reforçada a proposição de que os instrumentos criados são exógenos.

A conclusão resultante da tabela 6.5 aponta para uma maior confiabilidade para a estimativa dada pela coluna 3 para o efeito do incentivo fiscal sobre a renda de bilheteria. O efeito estimado, positivo e significativo ao nível de 5\%, alcança a magnitude de 0,05, sendo que a argumentação sobre a exogeneidade dos instrumentos e, principalmente, o teste de restrições sobreidentificadoras demonstram que essa estimativa é consistente para o valor verdadeiro do parâmetro.

Conforme discutido no capítulo 5, não foram encontrados candidatos a representar instrumentos para os valores captados por meio de investimentos do FSA e através de outras fontes. A menor relevância desses mecanismos de fomento justifica a exclusão de suas variáveis das estimações de elasticidades, nesse caso, relacionadas apenas ao incentivo fiscal. Ainda assim, tabela 11.2 do anexo reproduz os resultados principais que seguem com a inclusão das variáveis explicativas para o investimento do FSA e para as outras fontes de captação, sob a hipótese de que essas variáveis são exógenas no modelo para a bilheteria dos filmes nacionais.

Em resumo, os recursos de incentivo fiscal têm efeito positivo e significativo sobre a renda de bilheteria dos filmes nacionais, ainda que a magnitude do efeito seja pequena, correspondendo a uma elasticidade de 0,05.

\subsection{Qual o efeito dos valores incentivados sobre a receita relativa dos filmes nacionais?}

O modelo pertinente para o cálculo desses efeitos parciais consiste na regressão do preço médio do ingresso, medida para a receita relativa de um filme, contra os valores captados por uma produção. Compõem as estimações todos os filmes nacionais exibidos no país entre 1995 e 2016, por não haver pronunciados outliers dessa variável dependente e por 
conta de seu relativamente pequeno coeficiente de variaçã ${ }^{5}$.

Pela relativa semelhança entre os estimadores de MQO e de MQ2E, esses últimos que utilizam as variáveis instrumentais descritas para o modelo 3, e, principalmente, pela não rejeição da hipótese nula de que os valores incentivados são exógenos ao explicar o preço médio do ingresso, após controladas as características dos filmes optou-se por manter os resultados das estimações do modelo 4 construídos a partir do método de MQO.

A tabela 6.6 mostra, nas colunas 1 e 2, que apenas os valores captados com incentivo fiscal foram capazes de afetar positiva e significativamente o preço médio esperado de um filme nacional. Uma elevação de $\mathrm{R} \$ 1.000 .000$ na captação de incentivo fiscal eleva o preço médio do ingresso de um filme em $\mathrm{R} \$ 0,04$, ou então, eleva-o em 0,41 ponto percentual. Portanto, a política de fomento foi capaz de impactar positivamente o valor arrecadado em média de cada consumidor de filme nacional, porém, apenas por meio do instrumento do incentivo fiscal.

\subsection{Qual o efeito dos valores incentivados sobre a qualidade dos filmes nacionais?}

O modelo pertinente para o cálculo desses efeitos parciais consiste na regressão da avaliação do público de um filme nacional, medida da sua qualidade tal como entendida pelo consumidor, contra os valores captados. Compõem as estimações todos os filmes nacionais exibidos no país entre 1995 e 2016, por não haver pronunciados outliers dessa variável dependente e por conta de seu relativamente pequeno coeficiente de variaçãd 7 .

Analogamente ao modelo 5, pela relativa semelhança entre os estimadores de MQO e de MQ2E, esses últimos que utilizam as variáveis instrumentais descritas para o modelo 3, e, principalmente, pela não rejeição da hipótese nula de que os valores incentivados são exógenos ao explicar a avaliação do público dos filmes nacionais, após controladas as características dos filmes 8 optou-se por manter os resultados das estimações do modelo 5 construídos a partir do método de MQO.

5 Os coeficientes de variação para o público e para a bilheteria de filmes nacionais são iguais a 3,5 e 3,4, respectivamente, enquanto que para o preço médio do ingresso consiste em apenas 0,23.

6 Foram calculados p-valores de 0,9244, para o modelo em nível, e de 0,9907, para o modelo log-linear.

7 Os coeficientes de variação para o público e para a bilheteria de filmes nacionais são iguais a 3,5 e 3,4, respectivamente, enquanto que para o rating consiste em apenas 0,19 .

8 Foram calculados p-valores de 0,5192, para o modelo em nível, e de 0,4730, para o modelo log-linear. 
A tabela 6.6 mostra, nas colunas 3 e 4, que, inversamente ao modelo anterior, apenas os investimentos do FSA foram capazes de afetar positiva e significativamente o rating esperado de um filme nacional. Uma elevação de $\mathrm{R} \$ 1.000 .000$ no investimento do fundo eleva a avaliação do público de um filme médio em 0,1 ponto, ou então, eleva-a em 2,8 pontos percentuais. Portanto, a política de fomento foi capaz de impactar positivamente a qualidade do cinema nacional exclusivamente através do instrumento do investimento do FSA.

Tabela 6.6 - Estimação dos modelos que explicam a receita relativa e a avaliação do público dos filmes nacionais

\begin{tabular}{lcccc}
\hline Variável dependente: & $(1)$ & $(2)$ & $(3)$ & $(4)$ \\
& $P M I$ & $\ln (P M I)$ & Rating & $\ln ($ Rating $)$ \\
\hline IncentivoFiscal & $4,34 \mathrm{e}-08^{* *}$ & $4,07 \mathrm{e}-09^{* *}$ & $3,46 \mathrm{E}-09$ & $1,96 \mathrm{E}-10$ \\
& $(2,08 \mathrm{e}-08)$ & $(1,72 \mathrm{e}-09)$ & $(1,00 \mathrm{e}-08)$ & $(2,11 \mathrm{e}-09)$ \\
OutrasFontes & $1,44 \mathrm{E}-07$ & $2,10 \mathrm{e}-08^{*}$ & $2,02 \mathrm{E}-08$ & $3,12 \mathrm{E}-09$ \\
& $(1,31 \mathrm{e}-07)$ & $(1,18 \mathrm{e}-08)$ & $(9,53 \mathrm{e}-08)$ & $(1,91 \mathrm{e}-08)$ \\
InvestimentoFSA & $-5,31 \mathrm{E}-08$ & $-4,14 \mathrm{E}-09$ & $9,60 \mathrm{e}-08^{*}$ & $2,82 \mathrm{e}-08^{* * *}$ \\
& $(7,43 \mathrm{e}-08)$ & $(6,48 \mathrm{e}-09)$ & $(4,94 \mathrm{e}-08)$ & $(1,04 \mathrm{e}-08)$ \\
Ancine & $-5,998^{* * *}$ & $-0,362^{* * *}$ & $-0,640^{* * *}$ & $-0,119^{* *}$ \\
& $(0,937)$ & $(0,0560)$ & $(0,246)$ & $(0,0494)$ \\
Controles & $\mathrm{Sim}$ & $\mathrm{Sim}$ & $\mathrm{Sim}$ & $\mathrm{Sim}$ \\
\hline Observações & 1.241 & 1.241 & 1.099 & 1.099 \\
R-quadrado & 0,289 & 0,248 & 0,312 & 0,252 \\
\hline
\end{tabular}

Erros padrão robustos entre parênteses.

$* * * p<0,01,{ }^{* *} p<0,05, * p<0,1$.

Totalidade dos filmes nacionais exibidos entre 1995 e 2016. Número de filmes incentivados: 978. Controles: gênero, ano, origem regional, produtora, diretor.

\subsection{Intenção revelada da política pública: estímulo ao gênero de documentários}

O capítulo 5 apresentou como um objetivo final de investigação empírica a aferição da eficácia da política pública no cumprimento da intenção revelada de promoção dos documentários nacionais. Embora não manifesta na legislação, a política pública efetivada revelou uma atenção especial de seus gestores com relação ao gênero de documentários.

Supondo para a política pública uma motivação de beneficiar a estrutura socioeconômica da indústria do cinema envolvida na produção desse gênero, ou então, supondo 
uma motivação de correção da externalidade positiva que documentários podem configurar, por conta do seu potencial artístico e educativo em paralelo ao seu pequeno apelo comercial, instrumentos de política pública podem ter estimados os seus efeitos sobre variáveis de resultado específicas para o gênero de documentários. Em um primeiro momento, confirmando a constatação do capítulo 4 de que a proporção de documentários exibidos cresceu fortemente no pós-Ancine, a tabela 11.3 do anexo expõe o resultado da estimação do modelo de probabilidade linear apresentado no capítulo 5. A inclusão sucessiva de controles indica que, com o funcionamento da Ancine, a proporção de documentários nacionais exibidos cresceu em torno de 30 pontos percentuais. Portanto, o funcionamento da agência possibilitou, dentro da totalidade de filmes nacionais exibidos, um crescimento da oferta relativa de documentários.

A avaliação dos efeitos da política pública sobre a qualidade dos documentários nacionais, que resume o seu potencial de impacto sobre o público, utiliza o modelo para o rating dos filmes desse gênero, exposto no capítulo 5. Assim como para os modelos 4 e 5, os resultados das estimações de MQ2E experimentadas mostraram ser inadequada essa técnica, para esse modelo, frente aos resultados das estimações de MQO. A tabela 6.7 reproduz as colunas 3 e 4 da tabela 6.6. Assim como para a totalidade dos gêneros, também para os documentários o incentivo fiscal e as outras fontes não afetam de forma significativa o seu rating. Apenas o investimento do FSA apresentou um efeito positivo e significativo ao nível de 5\%, sendo que uma elevação de $\mathrm{R} \$ 100.000$ no investimento do fundo eleva a avaliação do público de um documentário médio em 1 ponto, ou então, eleva-a em 1,2 ponto percentual.

Portanto, ainda que apenas através do investimento do FSA, a política pública demonstrou ser capaz de expandir a qualidade dos documentários nacionais, contribuindo qualitativamente para a correção da externalidade positiva em que esse gênero pode implicar.

$* * *$

O resumo dos resultados apresentados acima implica nas seguintes constatações:

1. A Ancine não impactou a proporção de filmes nacionais exibidos no país. Além disso, há uma queda na proporção de exibição na comparação com origens como a Europa Ocidental, o Sudeste Asiático e a Oceania. 
Tabela 6.7 - Estimação do modelo que explica a avaliação do público dos documentários nacionais

\begin{tabular}{lcc}
\hline Variável dependente: & $(1)$ & $(2)$ \\
& Rating & $\ln ($ Rating $)$ \\
\hline IncentivoFiscal & $4,36 \mathrm{E}-08$ & $6,92 \mathrm{E}-09$ \\
& $(3,49 \mathrm{e}-08)$ & $(4,97 \mathrm{e}-09)$ \\
OutrasFontes & $4,37 \mathrm{E}-07$ & $5,49 \mathrm{E}-08$ \\
& $(4,90 \mathrm{e}-07)$ & $(6,87 \mathrm{e}-08)$ \\
InvestimentoFSA & $9,04 \mathrm{e}-07^{* *}$ & $1,22 \mathrm{e}-07^{* *}$ \\
& $(3,85 \mathrm{e}-07)$ & $(5,32 \mathrm{e}-08)$ \\
Ancine & $-0,343$ & $-0,0504$ \\
& $(0,349)$ & $(0,0485)$ \\
Controles & $\mathrm{Sim}$ & $\mathrm{Sim}$ \\
\hline Observações & 284 & 284 \\
R-quadrado & 0,163 & 0,159 \\
\hline
\end{tabular}

Erros padrão robustos entre parênteses.

*** $p<0,01,{ }^{* *} p<0,05,{ }^{*} p<0,1$.

Totalidade dos documentários exibidos entre 1995 e 2016. Número de documentários incentivados: 251.

Controles: gênero, ano, origem regional, produtora, diretor.

2. O funcionamento da Ancine não impactou o público esperado de filmes nacionais quando comparado ao de filmes internacionais. Ainda assim, a Ancine ampliou a proporção esperada de um filme nacional no total de público e na comparação com o grupo de controle.

3. A política de fomento, sob a forma do incentivo fiscal, teve um impacto positivo, significativo e de pequena magnitude sobre a bilheteria de filmes nacionais.

4. A política de fomento, sob a forma do incentivo fiscal, teve um impacto positivo e significativo sobre a receita relativa (preço médio do ingresso) de filmes nacionais.

5. A política de fomento, sob a forma do investimento do FSA, teve um impacto positivo e significativo sobre a qualidade (avaliação do público) de filmes nacionais.

6. Quanto à intenção revelada de promoção de documentários, a política pública, através do funcionamento da Ancine, teve êxito em expandir a proporção de documentários nacionais exibidos e, através do investimento do FSA, afetou positivamente a qualidade dos filmes desse gênero. 



\section{Robustez e extensões}

O presente capítulo objetiva validar os resultados apresentados no capítulo 6 a partir da exploração de diversas heterogeneidades pertinentes aos filmes exibidos e presentes na base de dados. Para os cinco modelos estimados anteriormente, foram regredidas as variáveis dependentes contra as variáveis de tratamento interagidas com dummies de gênero. Além disso, foram exploradas a possibilidade de existência de tendências origem-específicas para a variável do público e as distintas categorias de origem como referência para a comparação do público (modelo 2). Outros exercícios de robustez envolvem a decomposição dos valores captados com incentivo fiscal por segmento de atividade e a comparação do desempenho de bilheteria de filmes nacionais incentivados com não incentivados (modelo 3). Por fim, foram realizados exercícios de aleatorização para os modelos 2 e 3, a fim de certificar que os resultados encontrados não são espúrios.

\subsection{Modelo 1}

\subsubsection{Interações entre a variável de tratamento e dummies de gênero}

Os resultados apresentados na seção 6.1, que partem do modelo 1, o qual especifica a probabilidade de um filme exibido ser nacional, já dispõem implicitamente de um exercício de robustez, na medida em que a categoria de filmes internacionais é decomposta em filmes norte-americanos e na categoria de filmes de origens similares (Europa Ocidental, Sudeste Asiático e Oceania), tal como apontado pelo índice de convencionalidade construído no capítulo 4. Na seção 6.1, apontou-se que o efeito de diminuição da proporção de filmes nacionais exibidos no pós-Ancine decorre das origens similares.

A tabela 7.1, por sua vez, explora as heterogeneidades referentes aos gêneros dos filmes exibidos, novamente havendo a distinção referencial entre filmes nacionais e internacionais. O painel A reproduz as estimativas dispostas na tabela 6.1, enquanto que o painel B interage a dummy do período de funcionamento da Ancine com cada uma de seis categorias gerais de gênero definidas a partir das 18 categorias originais. Dessa forma, é possível apreender a diferença entre a probabilidade estimada de exibição de um filme nacional em comparação à de um filme internacional para cada grupo de gênero. 
A coluna 1 da tabela 7.1 demonstra que o gênero responsável pelo efeito negativo e significativo do funcionamento da Ancine sobre a proporção de filmes nacionais exibidos em comparação à totalidade de filmes internacionais consiste no drama ou romance (queda para o gênero de 16,5 pontos percentuais no pós-Ancine frente a uma queda geral de 7,2 pontos percentuais). Já a coluna 2 sugere que o efeito, quando contraposta a exibição de filmes nacionais com norte-americanos, deve-se à uma combinação entre os efeitos de cada grupo de gênero. Por fim, a coluna 3 indica que a comédia, justamente aquele para o qual o desempenho nacional de público e bilheteria é particularmente exitos $\llbracket 17$ implica em uma queda na proporção de exibição de filmes nacionais comparativamente à exibição de origens similares.

Tabela 7.1 - Interações entre a variável de tratamento e dummies de gênero

\begin{tabular}{lccc}
\hline $\begin{array}{l}\text { Variável dependente: } \\
\text { Nacional }\end{array}$ & $(1)$ & $(2)$ & $(3)$ \\
\hline A - Tratamento & & & \\
\hline Ancine & $-0,0720^{* *}$ & $-0,0764^{* *}$ & $-0,180^{* * *}$ \\
& $(0,0280)$ & $(0,0334)$ & $(0,0541)$ \\
\hline B - Tratamento*Gênero & & & \\
\hline Acao_Aventura & $-0,0934$ & $-0,105$ & $-0,0581$ \\
& $(0,0681)$ & $(0,0848)$ & $(0,118)$ \\
Comedia & $-0,0815$ & $-0,0682$ & $-0,237^{* * *}$ \\
& $(0,0592)$ & $(0,0778)$ & $(0,0814)$ \\
Drama_Romance & $-0,165^{* *}$ & $-0,0996$ & $-0,156^{*}$ \\
& $(0,0738)$ & $(0,0894)$ & $(0,0821)$ \\
Documentario & $-0,117$ & $-0,0778$ & $\#$ \\
Suspense_Terror & $(0,0862)$ & $(0,0913)$ & $\#$ \\
Animacao & 0,0155 & 0,0187 & 0,126 \\
& $(0,0517)$ & $(0,0683)$ & $(0,138)$ \\
Controles & $\#$ & $\#$ & 0,112 \\
\hline Observações & $\#$ & $\#$ & $(0,166)$ \\
Previsão correta & Sim & Sim & Sim \\
\hline
\end{tabular}

Erros padrão robustos entre parênteses. ${ }^{* * *} p<0,01,{ }^{* *} p<0,05,{ }^{*} p<0,1$.

\# Parâmetros não estimados em virtude de excessiva multicolinearidade.

Filmes exibidos entre 2001 e 2016.

Controles: gênero, ano.

1 Vide as subseções abaixo. 


\subsection{Modelo 2}

\subsubsection{Regressões com tendências grupo-específicas}

Um primeiro exercício de robustez pertinente ao modelo 2 consiste na inclusão de termos de tendência interagidos com dummies referentes a cada categoria de origem definida. Assim, controla-se por tendências específicas para cada origem, tanto para aquela a qual se aplica o tratamento de funcionamento da Ancine (Brasil) quanto para as origens do grupo de controlę $\varrho^{2}$

A inclusão de tendências grupo-específicas não somente expande o conjunto de variáveis de controle, como também aponta para a viabilidade ou não da hipótese de tendências paralelas entre os grupos de tratamento e de controle. Ao se permitir que as tendências dos grupos sejam distintas, devem ser comparados os efeitos de tratamento estimados sem e com os termos de tendência grupo-específicos. Caso os parâmetros estimados difiram substancialmente, há evidências contrárias à hipótese de identificação. Caso os parâmetros sejam semelhantes em sinal, em significância e em magnitude, então há evidências favoráveis à hipótese.

A tabela 7.2 abaixo ilustra o resultado das estimações que consideram os filmes exibidos entre 2001 e 2016 cujos públicos são inferiores ao percentil de 90\%. Novamente, as variáveis dependentes exploradas são o logaritmo natural do público e o share de público. Todos os controles disponíveis e mencionados no capítulo 6 foram utilizados.

A comparação da coluna 1 da tabela 7.2 com a coluna 3 da tabela 6.2 do capítulo 6, que considera o logaritmo natural do público, mostra que o modelo de diferençasem-diferenças para essa variável de resultado não é robusto à inclusão das tendências grupo-específicas. Isso porque há uma diferença notável entre a magnitude do efeito de tratamento com tendência grupo-específica (público médio 61,3 pontos percentuais superior para filmes nacionais no pós-Ancine, quando comparado com o público de filmes internacionais) e a magnitude sem tendência grupo-específica (efeito de tratamento de 30,1 pontos percentuai \{3. Além disso, de não significante, o parâmetro passa a uma significância ao nível de $10 \%$.

A comparação da coluna 2 da tabela 7.2 com a coluna 3 da tabela 6.3 do capítulo 6 ,

2 América Latina, EUA/Canadá, Europa Ocidental, Restante da Europa, Países Ibéricos, Sudeste Asiático, Oceania, Oriente Médio e África.

3 Efeitos de tratamento calculados a partir da expressão discutida em notas de rodapé do capítulo 6 : $\left(e^{0,478}-1\right) * 100 \approx 61,3 \%$ e $\left(e^{0,263}-1\right) * 100 \approx 30,1 \%$. 
Tabela 7.2 - Estimação do modelo de diferenças-em-diferenças (tendências grupoespecíficas)

\begin{tabular}{lcc}
\hline Variável dependente: & $(1)$ & $(2)$ \\
& ln_Publico & Share_Publico \\
\hline Nacional & $-2,764^{* * *}$ & $-0,00530^{* * *}$ \\
& $(0,271)$ & $(0,000457)$ \\
Ancine & $-1,158^{* * *}$ & $-0,00654^{* * *}$ \\
& $(0,195)$ & $(0,000500)$ \\
Nacional*Ancine & $0,478^{*}$ & $0,00349^{* * *}$ \\
& $(0,257)$ & $(0,000471)$ \\
Tendência grupo-específica & Sim & Sim \\
Controles & Sim & Sim \\
\hline Observações & 4.327 & 4.327 \\
R-quadrado & 0,473 & 0,456 \\
\hline
\end{tabular}

Erros padrão robustos entre parênteses.

*** $p<0,01,{ }^{* *} p<0,05,{ }^{*} p<0,1$.

Filmes exibidos entre 2001 e 2016. Observações com público abaixo do percentil de $90 \%$.

Controles: valores incentivados, gênero, ano, origem, origem regional, produtora, diretor.

que considera o share de público de cada filme, demonstra semelhança dos efeitos estimados do funcionamento da Ancine sobre a diferença de participação esperada de um filme nacional no público total anual na comparação com a participação esperada de um filme internacional $(0,35$ ponto percentual contra 0,42$)$, sendo que os sinais e as significâncias são igualmente equivalentes.

Em resumo, dos dois modelos estimados, apenas o share de público se mostra robusto à flexibilização de que cada categoria de origem disponha de uma tendência temporal própria para a variável de resultado. Como o efeito de tratamento do modelo para o logaritmo natural do público não foi significativo, tal como indicado no capítulo 6 , a falta de robustez à inclusão de termos de tendência grupo-específica não conduz a implicações para esse resultado.

\subsubsection{Interações entre a variável de tratamento e dummies de gênero}

Visando compreender a heterogeneidade por trás dos resultados apresentados no capítulo 6 para o modelo de diferenças-em-diferenças, a tabela 7.3 reproduz, no painel A, os parâmetros de tratamento para as quatro variáveis de resultado pertinentes ao público e que decorrem da estimação do modelo sem as observações cujo público excede o percentil 
de $90 \%$ e incluindo todos os controles disponíveis. Tais parâmetros estimados devem ser contrapostos aos resultados presentes no painel B, que correspondem a interações entre a variável de tratamento (interação entre o grupo de tratamento, Nacional, e o período de tratamento, Ancine) e dummies de gênerg ${ }^{4}$.

Tabela 7.3 - Interações entre a variável de tratamento e dummies de gênero

\begin{tabular}{lcc}
\hline Variável dependente: & $(1)$ & $(2)$ \\
& ln_Publico & Share_Publico \\
\hline A - Tratamento & & \\
\hline Nacional*Ancine & 0,263 & $0,00417^{* * *}$ \\
& $(0,222)$ & $(0,000453)$ \\
\hline B - Tratamento*Gênero & & \\
\hline Acao_Aventura & $-0,0212$ & $0,00395^{* * *}$ \\
& $(0,376)$ & $(0,000580)$ \\
Comedia & $0,527^{*}$ & $0,00415^{* * *}$ \\
& $(0,274)$ & $(0,000474)$ \\
Drama_Romance & 0,198 & $0,00404^{* * *}$ \\
& $(0,239)$ & $(0,000461)$ \\
Documentario & 0,403 & $0,00448^{* * *}$ \\
Suspense_Terror & $(0,263)$ & $(0,000449)$ \\
& $-0,826^{* *}$ & $0,00363^{* * *}$ \\
Animacao & $(0,358)$ & $(0,000499)$ \\
& $-0,179$ & $0,00326^{* * *}$ \\
Controles & $(0,402)$ & $(0,000589)$ \\
\hline Observações & Sim & Sim \\
R-quadrado & 4.327 & 4.327 \\
\hline
\end{tabular}

Erros padrão robustos entre parênteses.

*** $p<0,01, * * p<0,05,{ }^{*} p<0,1$.

Filmes exibidos entre 2001 e 2016. Observações com público abaixo do percentil de $90 \%$. Controles: valores incentivados, gênero, ano, origem, origem regional, produtora, diretor.

A comparação dos parâmetros estimados presentes na coluna 1 entre os painéis A e B demonstra que os gêneros cujo efeito de tratamento estimado é superior ao efeito indiscriminado consiste na comédia e no documentário, enquanto que a ação ou aventura, o drama ou romance, o suspense ou terror e a animação têm parâmetros estimados inferiores. Quanto à significância, todos os parâmetros gênero-específicos são equivalentes aos efeitos indiscriminados, à exceção da comédia (positivo e significativo a 10\%) e do suspense

4 As 18 categorias de gênero que decorrem da classificação da IMDb foram agregadas em seis: ação ou aventura, comédia, drama ou romance, documentário, suspense ou terror e animação. 
ou terror (negativo e significativo a $5 \%$ ) para a variável de resultado do logaritmo natural do público. Com relação às heterogeneidades por gênero do efeito de tratamento da Ancine aplicado à variável de resultado do share de público, todos os parâmetros gêneroespecíficos estimados são equivalentes em termos de significância e estatisticamente iguais em magnitude quando comparados ao efeito de tratamento indiscriminado.

Em resumo, para a variável de resultado do logaritmo natural do público, os gêneros que mais contribuem para elevar o efeito de tratamento estimado do funcionamento da Ancine sobre o desempenho de filmes nacionais comparativamente ao de filmes internacionais consistem na comédia e no documentário. Os efeitos mais inexpressivos, por sua vez, decorrem do suspense ou terror e da animação.

Para a variável de resultado do share de público, o efeito de tratamento estimado é estatisticamente equivalente para todos os gêneros, de modo que a elevação de 0,42 ponto percentual na participação esperada de um filme nacional no total de público e na comparação com a participação esperada de um filme internacional parece não depender do gênero específico de um filme.

\subsubsection{Filmes internacionais tendo como referência distintas categorias de ori- gem}

Restringir a definição da variável Nacional para que tenha como contraposição aos filmes nacionais categorias específicas de origem representa modificar o grupo de controle com relação ao qual o desempenho dos filmes nacionais é comparado. Assim, a variável de tratamento passa a ser específica para a comparação das variáveis de resultado de filmes nacionais frente àquelas correspondentes a categorias de origem particulares.

Utilizando de definições da variável Nacional que contrapõem filmes nacionais com origens específicas, foram reproduzidas as regressões de diferenças-em-diferenças para as variáveis de resultado do logaritmo natural do público e do share de público, considerando apenas as observações cujo público seja inferior ao percentil de $90 \%$ e incluindo todos os controles disponíveis.

A tabela 7.4 abaixo contrapõe os filmes nacionais com os filmes norte-americanos (colunas 1 e 2) e com os filmes de origens similares (colunas 3 e 4), seguindo a exposição 
das médias por origem do índice de convencionalidade (capítulo 4) Tendo por referência as tabelas 6.2 e 6.3 do capítulo 6, percebe-se grande semelhança entre os efeitos de tratamento estimados para a comparação do desempenho de filmes nacionais com filmes internacionais de qualquer origem (coluna 3 das tabelas 6.2 e 6.3) e os efeitos estimados para a comparação com filmes norte-americanos (colunas 1 e 2 da tabela 7.4 ), o que decorre de que quase $60 \%$ dos filmes internacionais exibidos sejam norte-americanos.

Tabela 7.4 - Regressões de diferenças-em-diferenças para categorias específicas de origem

\begin{tabular}{lcccc}
\hline Variável dependente: & $(1)$ & $(2)$ & $(3)$ & $(4)$ \\
& $\ln ($ Publico $)$ - EUA & Share_Publico - EUA & $\ln ($ Publico $)$ - Similares & Share_Publico - Similares \\
\hline Nacional & $-2,762^{* * *}$ & $-0,00449^{* * *}$ & $-1,738^{* * *}$ & $-0,00171^{* *}$ \\
Ancine & $(0,266)$ & $(0,000466)$ & $(0,410)$ & $(0,000722)$ \\
& $-1,052^{* * *}$ & $-0,00630^{* * *}$ & $-0,314$ & $\left(0,00316^{* * *}\right.$ \\
Nacional*Ancine & $(0,208)$ & $(0,000555)$ & $-0,190102)$ \\
& 0,18 & $0,00418^{* * *}$ & $(0,389)$ & $0,00158^{* *}$ \\
Controles & $(0,224)$ & $(0,000446)$ & Sim & $(0,000720)$ \\
\hline Observações & Sim & Sim & 2.128 & Sim \\
R-quadrado & 2.799 & 2.799 & 0,42 & 2.128 \\
\hline
\end{tabular}

Erros padrão robustos entre parênteses.

*** $p<0,01,{ }^{* *} p<0,05,{ }^{*} p<0,1$.

Filmes exibidos entre 2001 e 2016. Observações com público abaixo do percentil de $90 \%$.

Controles: valores incentivados, gênero, ano, origem, origem regional, produtora, diretor.

Em consonância com os resultados do modelo 1, as colunas 3 e 4 da tabela|7.4 mostram menor eficácia do funcionamento da Ancine ao impactar o desempenho de filmes nacionais comparativamente ao de filmes de origens como a Europa Ocidental, o Sudeste Asiático e a Oceania, categorias as quais, além de semelhantes ao Brasil, tendo por critério o índice de convencionalidade médio, também são as principais em termos de exibição, excetuando-se os EUA. O parâmetro de tratamento estimado para o modelo da variável do logaritmo natural do público, além de igualmente não significativo, mostra-se, inclusive, negativo. Já o efeito estimado sobre a participação esperada de filmes nacionais no total de público e na comparação com a participação de filmes internacionais é inferior em significância (a 5\%, ao invés de a 1\%) e em magnitude (aumento de 0,16 ponto percentual, ao invés de 0,42).

A tabela|12.1 do anexo mostra o resultado das estimações dos modelos de diferençasem-diferenças para o logaritmo natural do público e para o share de público, comparando

5 As origens com índice de convencionalidade muito próximo ao do Brasil são a Europa Ocidental, o Sudeste Asiático e a Oceania. 
o desempenho dos filmes nacionais com o correspondente a cada uma das nove categorias de origem internacionais, de modo que foram regredidos nove modelos separadamente. Quanto ao modelo do logaritmo natural do público, encontra-se que as categorias cujo parâmetro estimado é superior ao indiscriminado em termos de origem são a América Latina e o Restante da Europa, sendo que as demais sete origens apresentam um parâmetro inferior, inclusive, com seis delas indicando uma queda no público esperado de filmes nacionais comparativamente ao de filmes internacionais, embora nenhum dos parâmetros seja estatisticamente significante.

Quanto ao modelo do share de público, apenas os EUA/Canadá e a Europa Ocidental apresentam parâmetros positivos e significativos, enquanto que o correspondente à regressão da Oceania é negativo e significativo. Como é positivo e significativo o efeito geral estimado do funcionamento da Ancine sobre a participação esperada de um filme nacional no total de público e na comparação com a participação esperada de um filme internacional, conclui-se que a totalidade desse efeito decorre, principalmente, da contraposição do desempenho dos filmes nacionais com os filmes norte-americanos.

Em resumo, a eficácia do funcionamento da Ancine para beneficiar o desempenho dos filmes nacionais comparativamente ao dos filmes internacionais, conforme encontrado com o resultado da estimação do modelo de diferenças-em-diferenças para o share de público, aplica-se apenas à contraposição com os filmes norte-americanos. Com relação ao modelo do logaritmo natural do público, encontra-se que os filmes nacionais perdem público frente a grande parte das categorias de origem.

\subsubsection{Aleatorização das definições das variáveis Nacional e Ancine}

Um exercício de robustez adicional verifica a validade dos resultados encontrados a partir da aleatorização das variáveis envolvidas na definição da variável de tratamento, nesse caso, o funcionamento da Ancine voltado à promoção dos filmes nacionais em contraposição aos filmes internacionais. Deseja-se que o parâmetro de tratamento estimado a partir dos dados reais seja suficientemente distinto daqueles resultantes da estimação com dados simulados.

Como o único modelo de diferenças-em-diferenças que apresentou um efeito de tratamento estatisticamente significativo foi aquele para a variável de resultado do share de público, aplica-se a apenas esse modelo o exercício de aleatorização. Os procedimen- 
tos de simulação foram conduzidos separadamente para a definição aleatória da variável Nacional $_{i t}$, que distingue entre filmes nacionais e internacionais, e para a definição aleatória da variável Ancine $_{i t}$, que distingue entre filmes exibidos anterior e posteriormente a 2004.

Uma vez definido aleatoriamente o valor da variável Nacional $_{i t}$ para toda a amostra, de tal forma que, contudo, mantenha-se a proporção de $26 \%$ de filmes nacionais, redefine-se a variável de tratamento dado pela interação entre a variável NacionalSim ${ }_{i t}$, gerada aleatoriamente, e a variável Ancine $i t$, tal como definida a partir dos dados reais, TratSim $_{i t}=$ NacionalSim $_{i t}$.Ancine $i t$. Regride-se, então, a equação de diferenças-emdiferenças para o share de público, utilizando-se dessa variável de tratamento simulada, com o que se obtém um parâmetro de tratamento estimado através de dados simulados. Tal procedimento foi repetido 1000 vezes, a fim de que seja válida a comparação com o parâmetro decorrente dos dados reais. Os parâmetros estimados por meio da aleatorização têm sua distribuição exposta em um histograma, sendo desejável que o parâmetro estimado de referência se encontre fora do intervalo de parâmetros estimados através da simulação.

Procedimentos análogos foram conduzidos para a variável Ancine ${ }_{i t}$, sendo que a simulação dos dados foi orientada de modo a manter a proporção efetiva de $93 \%$ de filmes exibidos no pós-2004. Agora, a variável de tratamento simulada é definida a partir de AncineSim $_{i t}$, TratSim $_{i t}=$ Nacional $_{i t}$.AncineSim $i t$. Por fim, ambos os procedimentos foram aplicados às três definições amostrais utilizadas para o modelo de diferenças-emdiferenças do share de público: amostra completa, observações com público abaixo do percentil de $99 \%$ e observações com público abaixo do percentil de 90\%. A figura 7.1 abaixo expõe a distribuição dos parâmetros de tratamento estimados tendo por base as aleatorizações da variável Nacional $_{i t}$ (figura (a)) e da variável Ancine ${ }_{i t}$ (figura (b)), considerando-se a amostra completa. A figura 12.1 do anexo ilustra os mesmos exercícios para as amostras restritas às observações abaixo dos percentis de $99 \%$ e de 90\%, respectivamente.

Observa-se da figura|7.1 que o parâmetro decorrente da estimação com os dados reais se encontra bastante afastado do intervalo de parâmetros estimados a partir dos exercícios de simulação. Portanto, trata-se de uma nova evidência de que os resultados apresentados no capítulo 6, para o modelo de diferenças-em-diferenças do share de público, de fato indicam que, com o funcionamento da Ancine, ampliou-se a participação esperada no total 
Figura 7.1 - Distribuição dos parâmetros de tratamento estimados a partir da aleatorização das variáveis Nacional e Ancine - Amostra completa
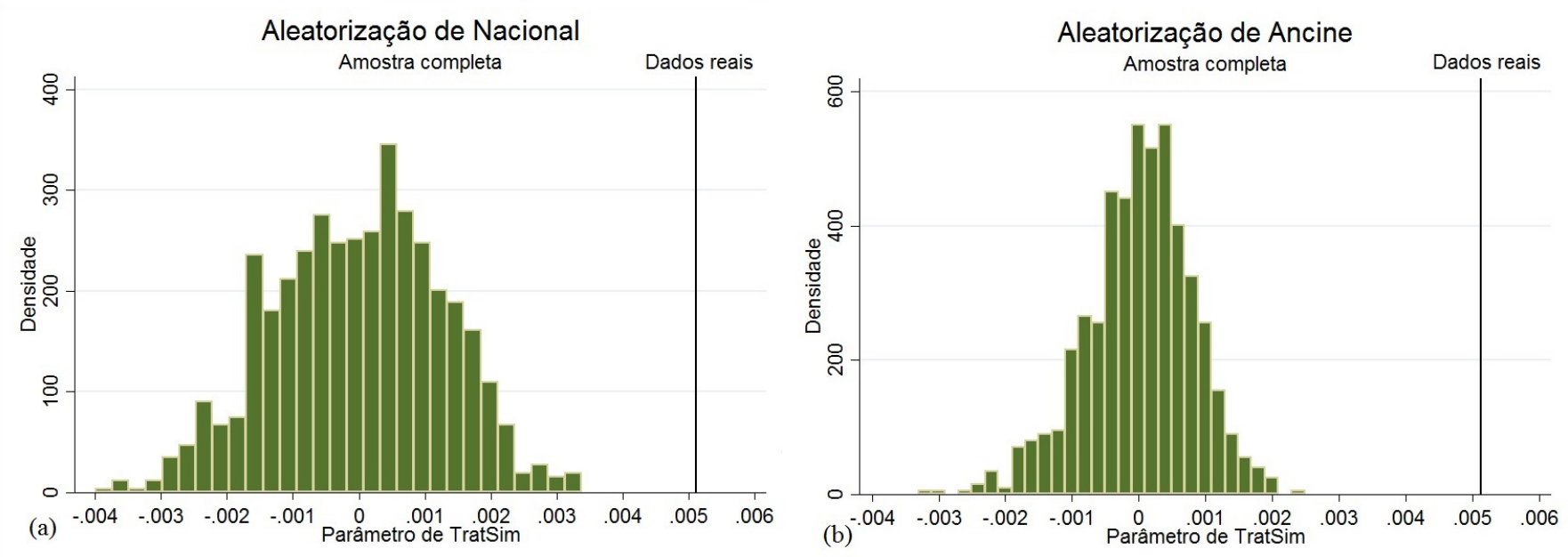

de público de um filme nacional.

\subsection{Modelo 3}

\subsubsection{Interações entre os valores incentivados e dummies de gênero}

Ao interagir a variável de captação de incentivo fiscal com dummies de gênero, é possível discriminar os efeitos dos valores incentivados sobre a renda de bilheteria dos filmes nacionais considerando explicitamente as distintas linguagens e conteúdos que correspondem aos distintos gêneros existentes ${ }^{6}$.

A tabela 7.5 abaixo ilustra, no painel A, a estimação pelo método de MQ2E da elasticidade do incentivo fiscal. O painel B, por sua vez, considera, na estimação por variáveis instrumentais, as interações com as seis dummies de gênero do valor captado com incentivo fiscal e de cada instrumento disponível. Foram consideradas apenas as observações cuja bilheteria é inferior ao percentil nacional de $99 \%$, além de que foram incluídos nas regressões todos os controles disponíveis. Em notas de rodapé anexas à tabela 7.5 , encontram-se os resultados de testes pertinentes à estimação com variáveis instrumentais, sendo que os instrumentos utilizados consistem nos mesmos presentes na especificação de referência para o modelo que explica a bilheteria dos filmes nacionais.

6 Novamente, as 18 categorias de gênero originais foram agregadas em 6 grupos: ação ou aventura, comédia, drama ou romance, documentário, suspense ou terror e animação. 
Tabela 7.5 - Interações entre os valores incentivados e dummies de gênero - Estimação de VI

\begin{tabular}{lc}
\hline $\begin{array}{l}\text { Variável dependente: } \\
\ln (\text { Bilheteria })\end{array}$ & Incentivo fiscal \\
\hline A - Valores incentivados & $0,0518^{* *}$ \\
\hline Elasticidade & $(0,0225)$ \\
\hline B - Valores*Gênero & \\
\hline Animacao & $5,028^{* *}$ \\
& $(2,014)$ \\
Acao_Aventura & 0,0459 \\
& $(0,0737)$ \\
Comedia & 0,0306 \\
& $(0,0962)$ \\
Drama_Romance & $0,0767^{* *}$ \\
& $(0,0335)$ \\
Documentario & 0,0365 \\
& $(0,0338)$ \\
Suspense_Terror & 0,077 \\
Controles & $(0,0740)$ \\
\hline Observações & Sim \\
R-quadrado & 425 \\
\hline
\end{tabular}

Erros padrão robustos entre parênteses. ${ }^{* * *} p<0,01,{ }^{* *} p<0,05,{ }^{*} p<0,1$.

Filmes exibidos entre 2007 e 2016.

Controles: gênero, ano, origem regional, produtora, diretor.

Teste de significância conjunta dos instrumentos (primeiro estágio): $p$-valor $=0,0000$ para os seis gêneros.

Teste de restrições sobreidentificadoras: $p$ - valor $=0,1636$.

Teste de endogeneidade: $p$-valor $=0,0796$.

Apenas a animação e o drama ou romance apresentam parâmetros estimados significativos e superiores em magnitude ao parâmetro estimado de forma indiscriminada quanto aos gêneros. Em particular, a elasticidade estimada para a animação corresponde a cerca de 100 vezes a elasticidade estimada indiscriminadamente. A significância desses dois parâmetros estimados de interação com dummies de gênero é equivalente àquela para o parâmetro estimado geral (significância a 5\%). 


\subsubsection{Distinção do incentivo fiscal a um filme destinado a cada segmento de atividade}

Um exercício de robustez que auxilia na compreensão do efeito causal da captação de incentivo fiscal sobre a renda de bilheteria consiste na distinção dos valores captados por um filme destinados à produção, à distribuição e à exibição, com o que se pode compreender através de que segmento de atividade a política de fomento é mais eficaz.

A tabela 7.6, nas colunas 1 e 2, apresenta o resultado das estimações de MQO, enquanto que, nas colunas 3 e 4, encontra-se o resultado das estimações com variáveis instrumentais. As colunas 2 e 4, diferentemente das colunas 1 e 3, distingue o incentivo fiscal por segmento de atividade (produção, distribuição e exibição). As quatro especificações excluem os outliers acima do percentil de bilheteria nacional de $99 \%$ e utilizam todos os controles disponíveis e mencionados no capítulo 6. Também aqui a estimação de MQ2E partiu dos instrumentos utilizados na especificação de referência para o modelo que explica a bilheteria dos filmes nacionais.

Tabela 7.6 - Distinção do efeito do incentivo fiscal por segmento de atividade de um filme - Estimação de VI

\begin{tabular}{lcccc}
\hline Variável dependente: & $(1)$ & $(2)$ & $(3)$ & $(4)$ \\
$\ln ($ Bilheteria) & MQO & MQO & MQ2E & MQ2E \\
\hline $\ln$ (IncentivoFiscal) & $0,0788^{* * *}$ & & $0,0518^{* *}$ & \\
& $(0,0155)$ & & $(0,0225)$ & \\
Produção & & $0,0746^{* * *}$ & & $0,0565^{* *}$ \\
& & $(0,0150)$ & & $(0,0269)$ \\
Distribuição & & 0,0111 & & $-0,0426$ \\
& & $(0,0197)$ & & $(0,126)$ \\
Exibição & & 0,0234 & & 0,111 \\
& & $(0,0464)$ & & $(0,168)$ \\
Controles & Sim & Sim & Sim & Sim \\
\hline Observações & 514 & 514 & 425 & 425 \\
R-quadrado & 0,528 & 0,528 & 0,543 & 0,532 \\
\hline
\end{tabular}

Erros padrão robustos entre parênteses. ${ }^{* * *} p<0,01,{ }^{* *} p<0,05,{ }^{*} p<0,1$.

Filmes exibidos entre 2007 e 2016.

Controles: gênero, ano, origem regional, produtora, diretor.

Teste de significância conjunta dos instrumentos (primeiro estágio): $p$-valor $=0,0000$ (coluna $4)$.

Teste de restrições sobreidentificadoras: $p-$ valor $=0,4884$ (coluna 4).

Teste de endogeneidade: $p$-valor $=0,0946$ (coluna 4).

Tanto as estimações de MQO quanto as de MQ2E demonstram, por conta da signi- 
ficância exclusiva do segmento da produção nas colunas 2 e 4 e através da comparação entre os parâmetros de incentivo fiscal nas colunas 1 e 3 com os parâmetros para a produção nas colunas 2 e 4, que apenas o incentivo à produção é relevante para impactar a renda de bilheteria de um filme nacional. O padrão de concessão de incentivos parece refletir isso, dado o predomínio do incentivo à produção, conforme demonstrado no capítulo 3. Com efeito, dos filmes considerados nas regressões que resultam nas colunas 1-4 da tabela 7.6 , 376 tiveram captação para produção (valor médio de $\mathrm{R} \$ 2.737 .548$ ), enquanto que apenas 86 foram incentivados para distribuição (valor médio de $R \$ 430.440$ ) e 14 para exibição (valor médio de $\mathrm{R} \$ 879.275$ ).

\subsubsection{Aleatorização da definição das variáveis instrumentais para o incentivo fiscal}

A robustez dos resultados da instrumentalização do efeito do incentivo fiscal sobre a bilheteria dos filmes nacionais começou a ser indicada com o próprio teste de restrições sobreidentificadoras, que apontou para a exogeneidade do conjunto de instrumentos empregados na estimação de MQ2E. A utilização, na construção dos instrumentos, de diferentes especificações para a variável de rendimento das incentivadoras estatais (nível, variação, logaritmo natural) também sugeriu a robustez da estimativa de elasticidade encontrada e apresentada no capítulo 6.

De todo o modo, cabe uma análise adicional para reforçar que os resultados encontrados não são espúrios. Com a mesma inspiração da robustez para o modelo 2 em que foram aleatorizadas as definições das variáveis envolvidas na criação da variável de tratamento, podem ser aleatorizados componentes das variáveis instrumentais criadas a partir dos dados de captação de recursos por filmes e a partir dos dados de incentivadores. Relembrando, os instrumentos para cada classe de incentivador foram definidos como segue:

$$
z_{i t}^{f}=\sum_{k}\left[w_{i t}^{k s} \cdot\left(w^{k f s} \cdot y^{f s}\right)\right]
$$

Sendo $w_{i t}^{k s}$ o peso do mecanismo $k$ na captação no ano $s$ pelo filme $i$ exibido no ano $t$, $w^{k f s}$ o peso do incentivador $f$ no total incentivado no ano $s$ através do mecanismo $k$ e $y^{f s}$ uma variável para o rendimento do incentivador $f$ no ano $s$.

O principal dos componentes da equação (7.1) consiste no peso $w_{i t}^{k s}$, o qual vincula 
a filmes específicos a captação através de cada mecanismo. Essa variável foi, então, aleatorizada para cada mecanismo, de tal modo que se mantivesse a soma total original dos pesos $\left(\sum_{k} w_{i t}^{k s}=1\right)$. A partir desses pesos aleatorizados, construíram-se novamente as variáveis instrumentais para cada incentivador. Procedeu-se, na sequência, à regressão de MQ2E de referência, que utiliza instrumentos para as seguintes classes de incentivador: Petrobras, BNDES, Banco do Brasil, outras estatais, empresas privadas e pessoas físicas. O parâmetro estimado da elasticidade da bilheteria com relação ao incentivo fiscal foi armazenado, sendo esse procedimento repetido 1000 vezes. A distribuição dos parâmetros estimados obtidos através da estimação de variáveis instrumentais com pesos aleatorizados é apresentada na figura|7.2 abaixo.

Figura 7.2 - Distribuição dos parâmetros de elasticidade estimados a partir da aleatorização do peso de cada mecanismo no total captado por um filme

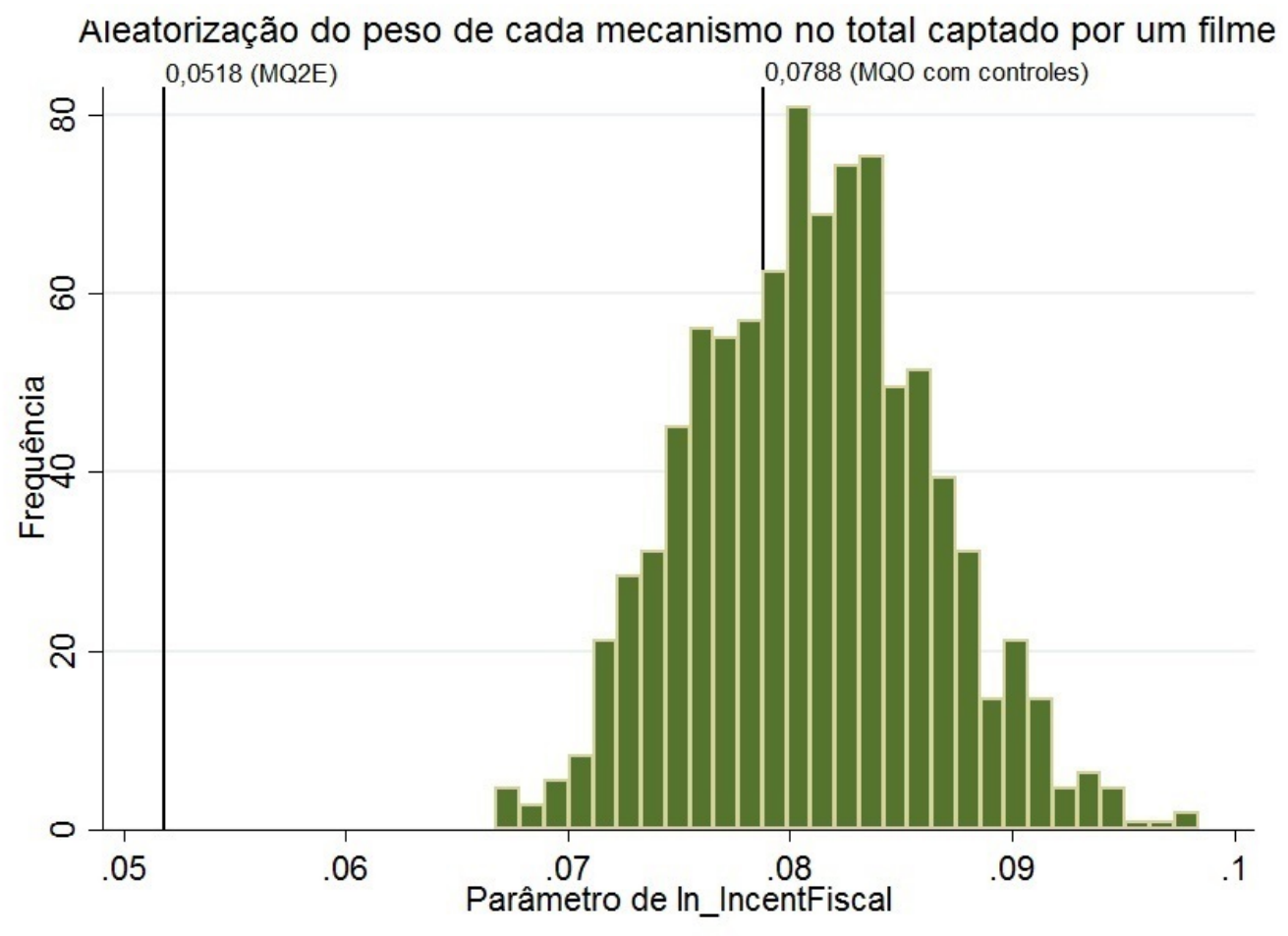

A primeira constatação relevante diz respeito à localização do parâmetro estimado a partir dos dados reais. A elasticidade de 0,0518 encontra-se fora do intervalo de parâmetros associados à aleatorização, o que aponta para a robustez do resultado de referência apresentado no capítulo. Interessante também como os parâmetros decorrentes da aleatorização se distribuem em torno do parâmetro estimado a partir do método de MQO com controles aplicado sobre os dados reais $(0,0788)$. Desse modo, aleatorizando-se 
a construção das variáveis instrumentais, anula-se a correção do viés e converge-se para o parâmetro estimado sem a instrumentalização. Em resumo, a figura 7.2 consiste em mais uma evidência da robustez do efeito estimado do incentivo fiscal sobre a bilheteria dos filmes nacionais.

\subsubsection{Propensity score-matching da bilheteria de filmes com e sem captação}

A tabela 12.2 do anexo utiliza do método de propensity score-matching para reforçar a compreensão dos resultados do modelo 3, que explica a bilheteria dos filmes nacionais a partir dos valores incentivados pela política de fomento, dentro do que se destaca o incentivo fiscal.

Utilizando de características dos filmes para estimar a diferença média do logaritmo natural da bilheteria de filmes com captação de incentivo fiscal em comparação ao logaritmo natural da bilheteria de filmes sem captação, o método de propensity score-matching estima o efeito médio do tratamento em que consiste a captação de incentivo fiscal, a partir da comparação entre filmes semelhantes em suas características, isto é, um filme incentivado e um filme não incentivado cujas probabilidades de captação de incentivo fiscal são semelhantes.

A primeira coluna da tabela 12.2 compara a bilheteria de documentários incentivados e de não incentivados, consistindo esse gênero em uma categoria cuja proporção de não captação é relativamente grande. Observa-se uma bilheteria esperada 26,8 pontos percentuais superior para documentários incentivados com renúncia fiscal na comparação com não incentivados, porém, tal efeito médio de tratamento não é significativo. As colunas 2 e 3, por sua vez, demonstram estimativas de efeitos médios de tratamento positivas e significativas, correspondendo a bilheterias esperadas superiores em 66,2 (documentário e drama) e em 74,5 (todos os gêneros) pontos percentuais, na medida em que um filme com captação de incentivo fiscal tenha sua bilheteria comparada com um filme semelhante sem captação. 


\subsection{Modelos 4 e 5}

\subsubsection{Interações entre os valores incentivados e dummies de gênero}

Assim como para a bilheteria dos filmes nacionais na tabela 7.5 , os efeitos dos valores incentivados sobre o preço médio do ingresso e sobre o rating dos filmes nacionais são discriminados de acordo com o gênero a que eles correspondem. A tabela 7.7 reproduz, no painel A, os efeitos indiscriminados, em que se percebe que o incentivo fiscal e o investimento do FSA apenas têm efeito significativo, respectivamente, sobre o preço médio do ingresso e sobre o rating.

Tabela 7.7 - Interações entre os valores incentivados e dummies de gênero

\begin{tabular}{lcccc}
\hline Variável dependente: & $(1)$ & $(2)$ & $(3)$ & $(4)$ \\
\hline A - Valores incentivados & Inc. fiscal & FSA & Inc. fiscal & FSA \\
\hline Sem interação & $4,07 \mathrm{e}-09^{* *}$ & $-4,14 \mathrm{E}-09$ & $1,96 \mathrm{E}-10$ & $2,82 \mathrm{e}-08^{* * *}$ \\
& $(1,72 \mathrm{e}-09)$ & $(6,48 \mathrm{e}-09)$ & $(2,11 \mathrm{e}-09)$ & $(1,04 \mathrm{e}-08)$ \\
\hline B - Valores*Gênero & Inc. fiscal & FSA & Inc. fiscal & FSA \\
\hline Acao_Aventura & $-2,12 \mathrm{E}-09$ & $2,90 \mathrm{E}-08$ & $-1,63 \mathrm{E}-08$ & $1,17 \mathrm{e}-07^{* *}$ \\
& $(5,35 \mathrm{e}-09)$ & $(2,58 \mathrm{e}-08)$ & $(1,10 \mathrm{e}-08)$ & $(4,78 \mathrm{e}-08)$ \\
Comedia & $-3,37 \mathrm{E}-10$ & $-1,45 \mathrm{E}-09$ & $5,49 \mathrm{E}-10$ & $1,49 \mathrm{E}-08$ \\
& $(3,54 \mathrm{e}-09)$ & $(5,89 \mathrm{e}-09)$ & $(4,41 \mathrm{e}-09)$ & $(1,28 \mathrm{e}-08)$ \\
Drama_Romance & $5,56 \mathrm{e}-09^{* *}$ & $-6,89 \mathrm{E}-09$ & $2,29 \mathrm{E}-09$ & $5,54 \mathrm{e}-08^{* * *}$ \\
& $(2,19 \mathrm{e}-09)$ & $(1,76 \mathrm{e}-08)$ & $(2,28 \mathrm{e}-09)$ & $(1,94 \mathrm{e}-08)$ \\
Documentario & $3,35 \mathrm{e}-08^{* * *}$ & $-1,82 \mathrm{E}-07$ & $1,42 \mathrm{e}-08^{* *}$ & $1,95 \mathrm{E}-08$ \\
& $(1,05 \mathrm{e}-08)$ & $(1,81 \mathrm{e}-07)$ & $(5,97 \mathrm{e}-09)$ & $(1,50 \mathrm{e}-07)$ \\
Suspense_Terror & $8,41 \mathrm{e}-09^{*}$ & $-8,52 \mathrm{e}-08^{* * *}$ & $6,00 \mathrm{E}-09$ & $7,34 \mathrm{E}-08$ \\
& $(4,96 \mathrm{e}-09)$ & $(2,26 \mathrm{e}-08)$ & $(8,14 \mathrm{e}-09)$ & $(4,47 \mathrm{e}-08)$ \\
Animacao & $6,43 \mathrm{E}-10$ & $3,14 \mathrm{E}-08$ & $-5,45 \mathrm{E}-08$ & $1,38 \mathrm{E}-08$ \\
& $(1,63 \mathrm{e}-08)$ & $(4,86 \mathrm{e}-08)$ & $(4,35 \mathrm{e}-08)$ & $(5,71 \mathrm{e}-08)$ \\
Controles & \multicolumn{3}{c}{ Sim } & \multicolumn{2}{c}{1.099} \\
\hline Observações & \multicolumn{2}{c}{1.241} & \multicolumn{2}{c}{0,271} \\
R-quadrado & \multicolumn{2}{c}{0,257} & \multicolumn{2}{c}{} \\
\hline
\end{tabular}

Erros padrão robustos entre parênteses.

*** $p<0,01,{ }^{* *} p<0,05, * p<0,1$.

Filmes nacionais exibidos entre 1995 e 2016.

Controles: gênero, ano, origem regional, produtora, diretor.

A análise por gênero (painel B) mostra que, para o preço médio do ingresso, o drama ou romance, o suspense ou terror e, sobretudo, o documentário apresentam um incentivo 
fiscal mais eficaz do que a média. O suspense ou terror, inclusive, representa o único grupo de gênero cujo investimento do FSA foi capaz de significativamente impactar o preço médio do ingresso de filmes nacionais.

A análise por gênero dos efeitos estimados sobre o rating é representativo de como o incentivo fiscal foi capaz de atender a uma demanda por documentários cuja provisão pelo mercado não deve ser eficiente em virtude das externalidades positivas associadas a essa classe de filmes. Como documentários têm uma contribuição para o bem-estar social que extrapola aquela sugerida pela bilheteria, uma vez que esse tipo de filme não participa do circuito comercial de cinema ou tem uma circulação restrita, a avaliação do público representa uma métrica mais adequada para o desempenho dessas obras.

Com efeito, a tabela 7.7 (coluna 3) indica que o incentivo fiscal para documentários foi o único capaz de significativamente afetar a variável do rating. Quanto ao investimento do FSA, não há efeito estimado significativo para os documentários, em virtude, talvez, da pequena proporção dessa classe de incentivo a esse gênerd7. Além disso, os dois gêneros responsáveis pelo efeito estimado indiscriminado significativo consistem na ação ou aventura e no drama ou romance (coluna 4).

\subsection{Intenção revelada da política pública: estímulo ao gênero de documentários}

\subsubsection{Interações entre os valores incentivados e dummies de qualificativo de gênero}

Por se tratar de regressões para um gênero específico, as interações dos valores incentivados se aplicam, no modelo para o rating dos documentários nacionais, sobre dummies de qualificativo de gênero. Os três qualificativos mais recorrentes para documentários são a música, o esporte e a biografia, ao que se adiciona uma categoria residual que contempla documentários a respeito de temas diversos, destacando-se a temática política e a educacional.

Como demonstrado pela tabela|7.8, da mesma forma como verificado para os parâmetros estimados indiscriminadamente quanto ao qualificativo de gênero, para nenhuma temática

7 Como apresentado no capítulo 4, entre 2008 e 2016, apenas $6 \%$ dos filmes incentivados e apenas $2 \%$ do valor total investido pelo fundo correspondem a documentários. 
Tabela 7.8 - Interações entre os valores incentivados e dummies de qualificativo de gênero

\begin{tabular}{lccc}
\hline Variável dependente: & $(1)$ & $\ln ($ Rating $)$ & $(2)$ \\
\hline A - Valores incentivados & Inc. fiscal & Outras fontes & FSA \\
\hline Sem interação & $6,92 \mathrm{E}-09$ & $5,49 \mathrm{E}-08$ & $1,22 \mathrm{e}-07^{* *}$ \\
& $(4,97 \mathrm{e}-09)$ & $(6,87 \mathrm{e}-08)$ & $(5,32 \mathrm{e}-08)$ \\
\hline B - Valores*Gênero & Inc. fiscal & Outras fontes & FSA \\
\hline Musica & $-1,16 \mathrm{E}-09$ & $1,67 \mathrm{E}-07$ & $\#$ \\
& $(1,21 \mathrm{e}-08)$ & $(1,95 \mathrm{e}-07)$ & $\#$ \\
Esporte & $-4,91 \mathrm{E}-08$ & $\#$ & $\#$ \\
& $(3,86 \mathrm{e}-08)$ & $\#$ & $\#$ \\
Biografia & $1,41 \mathrm{E}-08$ & $1,00 \mathrm{E}-07$ & $-2,16 \mathrm{E}-07$ \\
& $(9,35 \mathrm{e}-09)$ & $(1,78 \mathrm{e}-07)$ & $(2,45 \mathrm{e}-07)$ \\
Outros qualificativos & $8,03 \mathrm{E}-09$ & $4,50 \mathrm{E}-08$ & $1,19 \mathrm{e}-07^{* *}$ \\
& $(5,77 \mathrm{e}-09)$ & $(7,29 \mathrm{e}-08)$ & $(5,44 \mathrm{e}-08)$ \\
\hline Controles & & Sim & \\
Observações & & 284 & \\
R-quadrado & & 0,165 & \\
\hline
\end{tabular}

Erros padrão robustos entre parênteses.

*** $p<0,01,{ }^{* *} p<0,05,{ }^{*} p<0,1$.

Filmes nacionais exibidos entre 1995 e 2016.

Controles: qualificativo de gênero, ano, origem regional, produtora, diretor.

em particular o incentivo fiscal e as outras fontes de captação foram capazes de impactar significativamente o rating dos documentários nacionais. O investimento do FSA, por sua vez, tem o seu efeito sobre a qualidade dos documentários derivado de outras temáticas, como a política e a educação, uma vez que o parâmetro para os outros qualificativos consiste no único estatisticamente significativo e assemelha-se em magnitude ao parâmetro estimado sem interação. 


\section{Conclusão}

A disponibilidade de dados e informações para um estudo empírico em um setor pouco pesquisado pela microeconometria combinada à oportunidade de avaliação de uma importante política pública de cultura conduziram, neste trabalho: i) à análise da legislação e dos procedimentos de regulação e de fomento para o setor; ii) à descrição da indústria e do mercado brasileiros de cinema; e iii) à avaliação de impacto da recente política pública de cinema no Brasil.

A análise descritiva da política pública de cinema definiu o seu objetivo principal: a ampliação do acesso do consumidor brasileiro ao cinema nacional. Para tanto, as principais formas de intervenção disponíveis são: a política de fomento, a regulação que assume a forma de reserva de mercado e medidas de divulgação do produto nacional.

O organograma da política pública demonstra a sua centralização na Ancine e a divisão dos instrumentos disponíveis entre regulação, fiscalização e fomento, esse que se subdivide em incentivo fiscal (Lei do Audiovisual e Lei Rouanet) e investimento pelo FSA (Prodecine). A evolução institucional indicou progressivas maiores discricionariedade e diversidade de mecanismos na concessão de recursos. Isso, inclusive, garantiu uma mudança de prioridade no fomento com relação aos gêneros, havendo uma tendência maior ao incentivo daqueles mais rentáveis, como a comédia.

O processo de captação de recursos foi descrito, para o incentivo fiscal e para o investimento do FSA, tendo sido apresentados os incentivos de cada elemento constituinte e os principais parâmetros para a captação. Dados quanto aos pedidos por projeto e quanto ao tempo médio entre um primeiro e um último pedido de um mesmo projeto ilustraram o processo de captação. As informações dos incentivadores demonstraram uma clara dependência, entre 2007 e 2016, dos valores incentivados por empresas estatais, notadamente a Petrobras, o BNDES e o Banco do Brasil.

No que se refere à regulação, a principal medida consiste na reserva de mercado que estabelece um número mínimo de dias para a exibição de filmes nacionais em cinemas comerciais. Foram expostos os parâmetros para o cumprimento da medida e evidências do seu enforcement. Também foi ilustrado o cumprimento da fiscalização acerca da aplicação dos valores captados com incentivo fiscal. De um modo geral no que toca ao funciona- 
mento da Ancine, apresentaram-se evidências de que o início efetivo das operações da agência deve ser estimado para o ano de 2004.

O estudo do perfil da demanda brasileira por cinema e da estrutura da indústria nacional apontou para características predominantes referentes a dimensões como a origem, o gênero e a produtora dos filmes consumidos e produzidos no Brasil. Por exemplo, estabeleceu-se os EUA, a Europa Ocidental e o Brasil como as origens com maiores números de exibição e de consumo no país, da mesma forma como os gêneros da aventura, da animação e da comédia se destacam quanto a essa característica das obras assistidas. Demonstrou-se a importância de grandes produtoras e de diretores experientes quanto a médias de público e de valores captados, no caso de produções nacionais.

Os dados de avaliação do público da IMDb, medida de qualidade das obras exibidas, indicam uma associação negativa para categorias de origem e de gênero entre o rating e o público. Uma variável construída no decorrer do trabalho consistiu no chamado "índice de convencionalidade", que busca, de uma forma parametrizada, mensurar o nível de facilidade de absorção das obras pelo público.

A produção nacional de cinema se mostrou concentrada nos estados do Rio de Janeiro e de São Paulo, enquanto que os gêneros de destaque foram o documentário (elevados números de exibição, pequena média de público e grande proporção de incentivo) e a comédia (elevadas médias de público e de valor captado). Por fim, a diferença média entre o ano de primeiro pedido de incentivo fiscal e o ano de exibição permitiu uma estimação do tempo esperado de produção de um filme no Brasil, estimado para em torno de 4 anos.

O primeiro resultado da avaliação de impacto da política pública de cinema no Brasil revelou, a partir de um modelo de escolha binária, que a Ancine não foi capaz de afetar a probabilidade de um filme exibido ser nacional, mesmo comparando com filmes de origens semelhantes ao Brasil, como a Europa Ocidental, o Sudeste Asiático e a Oceania.

O funcionamento da Ancine também não impactou o público de filmes nacionais, comparativamente ao de filmes internacionais, conclusão obtida a partir de um modelo de diferenças-em-diferenças. Ao mesmo tempo, há evidências de que a agência foi eficaz em ampliar a participação média dos filmes nacionais com relação ao total anual de público e na comparação com os filmes internacionais.

A investigação empírica do efeito dos valores incentivados pela política de fomento sobre a bilheteria dos filmes nacionais levou à criação de variáveis instrumentais para o 
valor captado por um filme através do incentivo fiscal, utilizando-se de choques nos rendimentos dos incentivadores, que produzem variações exógenas nos incentivos. Verificou-se, então, que, embora de pequena magnitude, o incentivo fiscal implica em um efeito positivo e estatisticamente significativo sobre a bilheteria dos filmes nacionais.

Os valores incentivados pela política de fomento afetaram as receitas relativas dos filmes nacionais através do incentivo fiscal, resultado encontrado por meio da estimação das elasticidades do preço médio do ingresso com relação aos principais mecanismos de fomento. Já a qualidade dos filmes nacionais foi impactada apenas pelo investimento do FSA, cuja elasticidade sobre a avaliação do público mostrou-se positiva e estatisticamente significante.

Outros resultados obtidos dizem respeito apenas ao gênero de documentários, o qual foi contemplado por uma intenção revelada, e não prevista pela legislação, de promoção. Com efeito, o funcionamento da Ancine teve êxito em expandir a proporção de documentários nacionais exibidos, ao mesmo tempo em que o investimento do FSA afetou positivamente a qualidade dos filmes desse gênero.

Uma segunda seção de resultados empíricos dedicou-se a explorar extensões à metodologia principal e análises de robustez para validar os resultados apresentados. Assim, para diversas das regressões realizadas, foram estimadas interações entre as variáveis de tratamento e dummies de gênero, bem como se procedeu à aleatorização de variáveis de tratamento. Para o modelo de diferenças-em-diferenças do público, em particular, tendências grupo-específicas foram incluídas e diversas categorias de origem foram testadas. Para o modelo da bilheteria de filmes nacionais, os incentivos para diferentes segmentos de atividade tiveram seus efeitos estimados, além da aplicação da técnica de propensity score-matching para a bilheteria de filmes com e sem incentivo fiscal.

Em resumo, nas últimas décadas, a política pública de cinema valeu-se da regulação, da fiscalização e do fomento (através do incentivo fiscal, do investimento do FSA e de outras fontes de captação) para promover o acesso do consumidor brasileiro aos filmes nacionais, em um mercado com predomínio de exibição e de público por parte das produções internacionais, principalmente as norte-americanas. Nesse contexto, verificou-se que a política pública dedicou particular atenção ao gênero de documentários, especialmente no pós-Ancine. Constatações finais, de natureza metodológica, indicam que o funcionamento da Ancine elevou a participação esperada dos filmes nacionais no total de público anual 
e na comparação com os filmes internacionais, ao mesmo tempo em que o incentivo fiscal elevou, em pequena magnitude, a renda de bilheteria esperada dos filmes nacionais.

O resultado final da pesquisa, contudo, sugere que a recente política pública de cinema no Brasil tem resultados econômicos discutíveis, considerando a alternância da significância estatística dos impactos estimados para os diversos instrumentos de política. Talvez a maior falha da política de cinema tenha origem na sua própria concepção. A legislação não é clara quanto às ineficiências que se deseja corrigir, o que resulta em objetivos incertos e dificulta a avaliação da eficácia dos programas implementados. Um exemplo claro foi constatado a partir da particular preocupação demonstrada com a promoção do gênero de documentários. Ainda que se trate de um gênero sujeito à configuração de falhas de mercado, a legislação não enuncia esse ponto como justificativa para intervenção, tornando ambígua a real intenção da política pública junto a essa classe de filmes. A política de fomento, por fim, deveria buscar um maior envolvimento de incentivadores privados, dada a grande participação de estatais no incentivo fiscal e a exclusividade de recursos públicos do FSA. Com isso, a indústria poderia desenvolver mecanismos de financiamento sustentáveis e independentes da discricionariedade governamental.

Se é prática comum para qualquer pesquisa aplicada afirmar que as questões estabelecidas não se extenuam com os resultados encontrados, isto é reforçado para um trabalho cuja contribuição defendida consiste justamente em compor um segmento pouco explorado pelos estudos empíricos. Além do mais, a avaliação metodológica da política pública de cinema desenvolvida neste trabalho pretende ampliar a preocupação com um suporte rigoroso para conclusões a respeito da sua eficácia e eficiência em impactar as variáveis de resultado elegidas pelos objetivos da política.

Espera-se contribuir para uma maior aplicação de um instrumental empírico para a avaliação de políticas em cultura no Brasil, tanto no ambiente acadêmico quanto no setor público, para o que se orientou a criação de uma base de dados inédita com informações de público e bilheteria, valores incentivados e características diversas dos filmes exibidos no país. Por fim, o substrato de um estudo de mercado para o setor de cinema no país também pode contribuir para uma compreensão analítica do seu funcionamento, o que se volta para a política pública e igualmente para elementos do setor no âmbito privado. 


\section{Referências}

AGOSTINI, Claudio; SAAVEDRA, Eduardo. The Effects of Vertical Integration on the Release of New Films. Journal Of Media Economics, v. 24, n. 4, p.252-269, dez. 2011.

ANCINE. Relatório de Análise de Impacto. 2017.

Disponível em: <https://www.ancine.gov.br/pt-br/conteudo/relat-rio-de-lise-de-impactocota-de-tela>. Acesso em: 18 out. 2018.

APRO. Mapeamento e Impacto Econômico do Setor Audiovisual no Brasil: (2016). São Paulo: Sebrae, 2016.

AUBERT, Cécile; BARDHAN, Pranab K.; DAYTON-JOHNSON, Jeff. Artfilms, Handicrafts and Other Cultural Goods. University Of California Working Paper, v. 340, n. 4, p.1-32, nov. 2003.

BRASIL. Lei no 8313, de 23 de dezembro de 1991. Lei Rouanet. Brasília, 1991. Disponível em:

<http://www.planalto.gov.br/ccivil_03/LEIS/L8313cons.htm>. Acesso em: 27 ago. 2018. BRASIL. Lei no 8685, de 20 de julho de 1993. Lei do Audiovisual. Brasília, 1993. Disponível em: <http://www.planalto.gov.br/ccivil_03/LEIS/L8685.htm>. Acesso em: 27 ago. 2018.

BRASIL. Medida Provisória $n^{\circ}$ 2228-1, de 6 de setembro de 2001. MP que cria a Ancine. Brasília, 2001. Disponível em: <http://www.planalto.gov.br/ccivil_03/mpv/22281.htm>. Acesso em: 27 ago. 2018.

CHISHOLM, Darlene C.; MCMILLAN, Margaret S.; NORMAN, George. Product Differentiation and Film Programming Choice. Nber Working Paper Series, Cambridge, v. 12646, p.2-35, out. 2006.

CHISHOLM, Darlene C.. Motion pictures. In: TOWSE, Ruth. A Handbook of Cultural Economics. Cheltenham: Edward Elgar, 2011. p. 282-289.

COLLINS, Alan; SCORCU, Antonello E.; ZANOLA, Roberto. Distribution Conventionality in the Movie Sector: An Econometric Analysis of Cinema Supply. Managerial And Decision Economics, Nova Jersey, v. 30, n. 8, p.517-527, dez. 2009.

FORNAZARI, Fabio Kobol. Instituições do Estado e políticas de regulação e incentivo 
ao cinema no Brasil. Revista de Administração Pública, Rio de Janeiro, v. 40, n. 4, p.647-677, jul. 2006.

FSA. Documento de Diretrizes. 2008. Disponível em:

$<$ https://fsa.ancine.gov.br/sites/default/files/documentoDiretrizes2.pdf $>$. Acesso em: 27 ago. 2018.

IBGE. Sistema de Informações e Indicadores Culturais: 2007-2010. Rio de Janeiro: Ibge, 2013.

MICHEL, Rodrigo Cavalcante; AVELLAR, Ana Paula. Indústria cinematográfica brasileira de 1995 a 2012. Nova Economia, Belo Horizonte, v. 24, n. 3, p.491-516, set. 2014. SISTO, Andrea; ZANOLA, Roberto. Rational Addiction to Cinema? A Dynamic Panel Analysis of European Countries. Polis Working Papers, Alessandria, v. 41, p.1-26, abr. 2004.

SISTO, Andrea; ZANOLA, Roberto. Rationally Addicted to Cineman and TV? An Empirical Investigation of Italian Consumers. Polis Working Papers, Alessandria, v. 52, p.1-25, maio 2005.

VALIATI, Leandro; FIALHO, Ana Letícia do Nascimento (Org.). Atlas Econômico da Cultura Brasileira: Metodologia I. Porto Alegre: Editora Ufrgs, 2017.

WINK JUNIOR, Marcos Vinicio; MATTOS, Enlinson. Criação da Agência Reguladora e Leis de Incentivo à Cultura. Planejamento e Políticas Públicas, Brasília, v. 37, n. 1, p.39-75, dez. 2011.

ZAVERUCHA, Vera. Lei do Audiovisual: Passo a Passo. Brasília: Ministério da Cultura, Secretaria Para O Desenvolvimento Audiovisual, 1996. 


\section{Anexo A}

Anexo ao capítulo 3 de descrição da política pública.

Tabela 9.1 - Principais incentivadores (artigos $1^{\circ}, 1^{\circ} \mathrm{A}$ e 18 )

\begin{tabular}{lcc}
\hline Incentivador & Valor Total & \% \\
& (milhões de $\mathbf{R} \$$ de 2016) & (185 \\
\hline Petrobras & 156 & 15 \\
BNDES & 79 & 12 \\
SABESP & 41 & 6 \\
Banco do Brasil & 22 & 3 \\
FINAME & $1,3 \mathrm{mil}$ & 2 \\
\hline Total & & 100 \\
\hline
\end{tabular}

Fonte: Ancine. Elaboração própria.

Tabela 9.2 - Principais incentivadores (artigo $1^{o}$ )

\begin{tabular}{lcc}
\hline Incentivador & $\begin{array}{c}\text { Valor Total } \\
\text { (milhões de R\$ de 2016) }\end{array}$ & \% \\
\hline BNDES & 90 & 25 \\
Banco do Brasil & 41 & 11 \\
FINAME & 11 & 3 \\
MRS Logística & 11 & 3 \\
Lojas Cem S.A & 10 & 3 \\
\hline Total & 365 & 100 \\
\hline
\end{tabular}

Fonte: Ancine. Elaboração própria. 
Tabela 9.3 - Principais incentivadores (artigo $1^{\circ} \mathrm{A}$ )

\begin{tabular}{lcc}
\hline Incentivador & $\begin{array}{c}\text { Valor Total } \\
\text { (milhões de } \mathbf{R} \$ \text { de 2016) }\end{array}$ & \% \\
\hline Petrobras & 160 & 19 \\
SABESP & 71 & 9 \\
BNDES & 59 & 7 \\
Eletrobras & 17 & 2 \\
Caixa & 15 & 2 \\
\hline Total & 827 & 100 \\
\hline
\end{tabular}

Fonte: Ancine. Elaboração própria.

Tabela 9.4 - Principais incentivadores (artigo 18)

\begin{tabular}{lcc}
\hline Incentivador & $\begin{array}{c}\text { Valor Total } \\
\text { (milhões de R } \$ \text { de 2016) }\end{array}$ & \% \\
\hline Petrobras & 24 & 39 \\
Redecard & 16 & 26 \\
BNDES & 7 & 11 \\
Eletrobras & 2 & 3 \\
Caixa & 1 & 2 \\
\hline Total & 62 & 100 \\
\hline
\end{tabular}

Fonte: Ancine. Elaboração própria.

Tabela 9.5 - Principais incentivadores - Por classe de incentivador

\begin{tabular}{lcc}
\hline Incentivador & $\begin{array}{c}\text { Valor Total } \\
\text { (milhões de R } \$ \text { de 2016) }\end{array}$ & \% \\
\hline Estatal & 636 & 51 \\
Privado & 606 & 48 \\
Pessoa física & 12 & 1 \\
\hline Total & $1,3 \mathrm{mil}$ & 100 \\
\hline
\end{tabular}

Fonte: Ancine. Elaboração própria.

Tabela 9.6 - Proporções de adimplência e de inadimplência da Cota de Tela

\begin{tabular}{cccc}
\hline & $\begin{array}{c}\text { Cumprimento } \\
(\boldsymbol{\%})\end{array}$ & $\begin{array}{c}\text { Descumprimento } \\
\text { (da cota) } \boldsymbol{( \% )}\end{array}$ & $\begin{array}{c}\text { Descumprimento } \\
\text { (não envio do relatório) }\end{array}$ \\
\hline 2010 & 74,1 & 8,8 & 17,1 \\
2014 & 89,5 & 5,0 & 5,5 \\
2015 & 90,6 & 2,8 & 6,6 \\
\hline
\end{tabular}

Fonte: Ancine, Relatórios de Cota de Tela. 
Figura 9.1 - Mínimo de dias e de títulos distintos por número de salas (2016 e 2017)
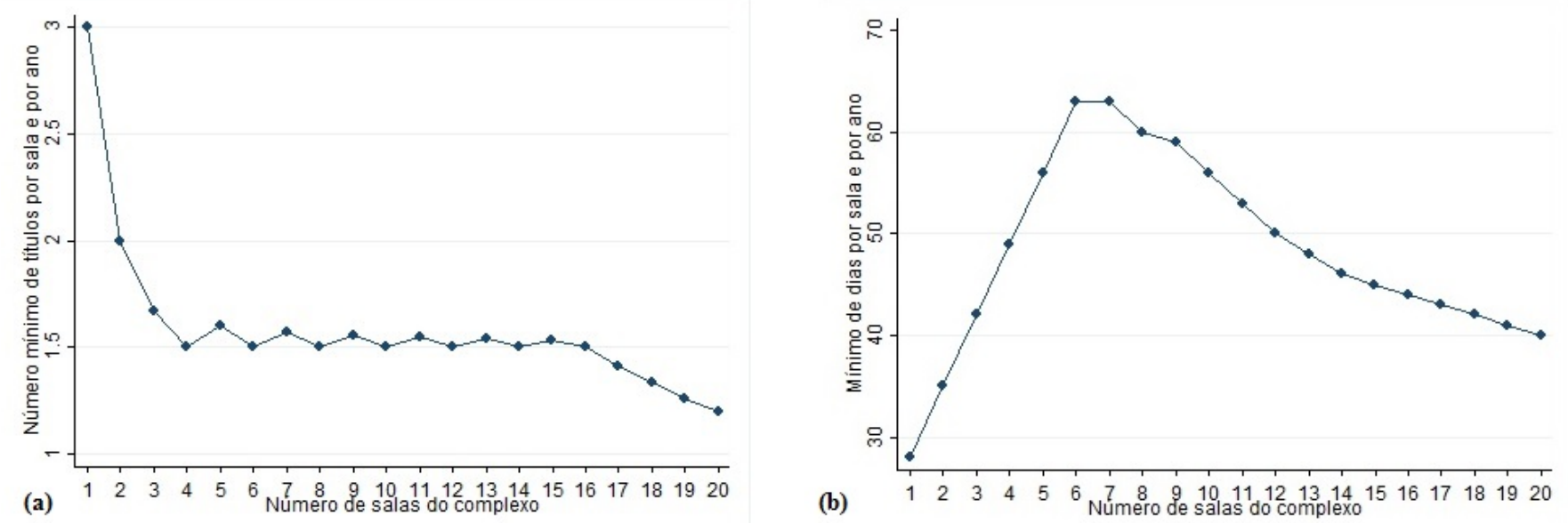

Fonte: Ancine, FilmeB. Elaboração própria.

Tabela 9.7 - Inadimplência da cota de tela por tamanho do complexo exibidor (\%)

\begin{tabular}{lcccccccc}
\hline Salas & $\mathbf{2 0 0 8}$ & $\mathbf{2 0 0 9}$ & $\mathbf{2 0 1 0}$ & $\mathbf{2 0 1 1}$ & $\mathbf{2 0 1 2}$ & $\mathbf{2 0 1 3}$ & $\mathbf{2 0 1 4}$ & $\mathbf{2 0 1 5}$ \\
\hline 1 & 49,0 & 40,8 & 33,5 & 33,7 & 60,2 & 52,1 & 33,1 & 25,6 \\
2 & 47,4 & 23,6 & 18,4 & 35,7 & 46,6 & 35,1 & 25,5 & 13,6 \\
3 & 53,0 & 27,8 & 22,6 & 24,6 & 46,1 & 32,8 & 26,6 & 7,6 \\
4 & 51,0 & 31,5 & 25,0 & 31,1 & 40,0 & 18,4 & 26,3 & 6,0 \\
5 & 60,0 & 17,0 & 16,3 & 30,6 & 35,8 & 10,8 & 24,1 & 1,1 \\
6 & 53,3 & 40,0 & 23,7 & 44,0 & 36,0 & 4,9 & 19,1 & 0,0 \\
7 & 36,8 & 19,0 & 12,5 & 48,1 & 20,0 & 10,0 & 34,2 & 0,0 \\
8 & 33,3 & 20,7 & 3,2 & 57,6 & 18,7 & 2,7 & 32,5 & 0,0 \\
9 & 80,0 & 11,1 & 0,0 & 60,0 & 8,3 & 0,0 & 23,1 & 0,0 \\
10 & 46,7 & 14,3 & 6,7 & 26,7 & 0,0 & 0,0 & 11,1 & 0,0 \\
$11+$ & 29,4 & 6,2 & 6,7 & 21,4 & 0,0 & 13,3 & 6,7 & 0,0 \\
\hline Média & 49,1 & 22,9 & 15,3 & 37,6 & 28,3 & 16,4 & 23,8 & 4,9 \\
\hline
\end{tabular}

Fonte: Ancine, Relatório de Impacto da Cota de Tela. 
Tabela 9.8 - Valores arrecadados com multas em virtude do descumprimento da Cota de Tela $(\mathrm{R} \$)$

\begin{tabular}{cc}
\hline Ano & $\begin{array}{c}\text { Total arrecadado com multas } \\
\text { (artigo }\end{array}$ \\
\hline 2009 & 667,56 \\
2010 & $2.283,69$ \\
2011 & $7.604,94$ \\
2012 & $86.681,20$ \\
2013 & $84.692,95$ \\
2014 & $1.457 .144,77$ \\
2015 & $571.786,04$ \\
2016 & $26.826,96$ \\
2017 & 0 \\
\hline
\end{tabular}

Fonte: Ancine.

Tabela 9.9 - Devolução de recursos captados com a Lei do Audiovisual (R\$)

\begin{tabular}{cc}
\hline Ano & $\begin{array}{c}\text { Valores captados com } \\
\text { incentivo fiscal devolvidos }\end{array}$ \\
\hline 2007 & 3.513 .108 \\
2008 & 1.422 .767 \\
2009 & 1.456 .273 \\
2010 & 269.940 \\
2011 & 690.671 \\
2012 & 1.649 .412 \\
2013 & 2.123 .293 \\
2014 & 3.676 .866 \\
2015 & 9.519 .012 \\
2016 & 18.800 .292 \\
2017 & 5.872 .600 \\
\hline
\end{tabular}

Fonte: Ancine.

Tabela 9.10 - Percentis do retorno do investimento do FSA

\begin{tabular}{lcc}
\hline Percentil & Bilheteria/Investimento (1) & Bilheteria/Investimento (2) \\
\hline $25 \%$ & $2,1 \%$ & $2,1 \%$ \\
$50 \%$ & $5,5 \%$ & $6,1 \%$ \\
$75 \%$ & $15,7 \%$ & $26,3 \%$ \\
$90 \%$ & $78,6 \%$ & $96,7 \%$ \\
$95 \%$ & $114,7 \%$ & $128,3 \%$ \\
\hline
\end{tabular}

Fonte: FSA. Elaboração própria.

(1) Projetos entre 2012 e 2017.

(2) Projetos entre 2012 e 2015. 


\section{Anexo B}

Anexo ao capítulo 4 de bases de dados e estatísticas descritivas.

Tabela 10.1 - Influência de países específicos sobre o público

\begin{tabular}{|c|c|c|c|c|c|}
\hline Origem & Filmes & Média & Origem & Filmes & Média \\
\hline Europa Ocidental & 967 & 163.753 & $\begin{array}{l}\text { Europa Ocidental } \\
\text { (com Reino Unido) }\end{array}$ & $342(35 \%)$ & 348.163 \\
\hline $\begin{array}{l}\text { Europa Ocidental } \\
\text { (com EUA) }\end{array}$ & $209(22 \%)$ & 587.921 & $\begin{array}{l}\text { Europa Ocidental } \\
\text { (com Alemanha) }\end{array}$ & $197(20 \%)$ & 202.347 \\
\hline Sudeste Asiático & 129 & 95.237 & $\begin{array}{l}\text { Europa Ocidental } \\
\text { (com Itália) }\end{array}$ & $159(16 \%)$ & 59.802 \\
\hline $\begin{array}{l}\text { Sudeste Asiático } \\
\text { (com EUA) }\end{array}$ & $17(13 \%)$ & 342.667 & $\begin{array}{l}\text { Europa Ocidental } \\
\text { (com França) }\end{array}$ & $604(62 \%)$ & 82.276 \\
\hline Brasil & 1.243 & 214.229 & América Latina & 160 & 38.258 \\
\hline Brasil (com EUA) & $17(1 \%)$ & 210.662 & $\begin{array}{l}\text { América Latina } \\
\text { (com Argentina) }\end{array}$ & $104(65 \%)$ & 51.377 \\
\hline Oriente Médio/África & 76 & 28.620 & $\begin{array}{l}\text { América Latina } \\
\text { (com Brasil) }\end{array}$ & $12(8 \%)$ & 84.224 \\
\hline $\begin{array}{l}\text { Oriente Médio/África } \\
\text { (com EUA) }\end{array}$ & $9(12 \%)$ & 108.162 & & & \\
\hline
\end{tabular}

Fonte: Ancine, FilmeB, IMDb. Elaboração própria.

Tabela 10.2 - Influência de qualificativos de gênero sobre o público

\begin{tabular}{lcc}
\hline Gênero e qualificativo & Filmes & Média \\
\hline Drama & 1.062 & 106.359 \\
Drama (com Guerra) & $63(6 \%)$ & 158.944 \\
Drama (com História) & $93(9 \%)$ & 213.774 \\
Gêneros de Aventura & 458 & 1.438 .142 \\
Gêneros de Aventura (com Fantasia) & $143(31 \%)$ & 2.006 .922 \\
Gêneros de Aventura (com Sci-Fi) & $129(28 \%)$ & 2.108 .937 \\
Documentário & 587 & 15.490 \\
Documentário (com Música) & $57(10 \%)$ & 54.471 \\
\hline
\end{tabular}

Fonte: Ancine, FilmeB, IMDb. Elaboração própria. 
Tabela 10.3 - Interação entre origens e gêneros e seu impacto sobre o público

\begin{tabular}{lcclcc}
\hline Origem/Gênero & Filmes & Média & \multicolumn{1}{c}{ Origem/Gênero } & Filmes & Média \\
\hline Brasil & 1.243 & 214.229 & EUA/Canadá e Comédia & 121 & 429.827 \\
Comédia & 306 & 512.586 & Gêneros de Aventura & 358 & 1.643 .853 \\
Brasil e Comédia & 112 & 901.843 & EUA/Canadá e Gêneros de Aventura & 250 & 1.973 .188 \\
Documentário & 587 & 15.490 & Europa Ocidental & 967 & 163.753 \\
Brasil e Documentário & 445 & 9.858 & Europa Ocidental e Documentário & 40 & 20.771 \\
EUA/Canadá & 2.130 & 682.345 & & & \\
\hline
\end{tabular}

Fonte: Ancine, FilmeB, IMDb. Elaboração própria.

Tabela 10.4 - Regressões da renda de bilheteria contra o índice de convencionalidade

\begin{tabular}{|c|c|c|}
\hline Var. Dep.: Bilheteria $a_{i t}$ & (1) & $(2)$ \\
\hline \multirow[t]{2}{*}{ Índice de Convencionalidade (\%) } & 0,0861 & 0,0576 \\
\hline & $(0,0014)^{* * *}$ & $(0,0031)^{* * *}$ \\
\hline Controles & Não & Sim \\
\hline \multirow[t]{2}{*}{ Segundo quartil (Indice_Convenc) } & 1,0293 & $-0,0336$ \\
\hline & $(0,0784)^{* * *}$ & $(0,0953)$ \\
\hline \multirow[t]{2}{*}{ Terceiro quartil (Indice_Convenc) } & 2,7176 & 0,8683 \\
\hline & $(0,0782)^{* * *}$ & $(0,1295)^{* * *}$ \\
\hline \multirow[t]{2}{*}{ Quarto quartil (Indice_Convenc) } & 4,3559 & 2,0109 \\
\hline & $(0,0770)^{* * *}$ & $(0,1501)^{* * *}$ \\
\hline Controles & Não & Sim \\
\hline $\mathrm{N}$ & 5.067 & 4.942 \\
\hline
\end{tabular}

Erros-padrão heterocedásticos-robustos entre parênteses.

*** $p<0,01,{ }^{* *} p<0,05,{ }^{*} p<0,1$. 
Tabela 10.5 - Estatísticas de público de filmes nacionais por gênero

\begin{tabular}{lcccc}
\hline Gênero & Filmes & $\begin{array}{c}\text { Média } \\
\text { (milhares) }\end{array}$ & $\begin{array}{c}\text { Máximo } \\
\text { (milhões) }\end{array}$ & $\begin{array}{c}\text { Agregado } \\
\text { (milhões) }\end{array}$ \\
\hline Comédia e Aventura & $11(0,8 \%)$ & 871,5 & 2,7 & 9,6 \\
Comédia & $130(9,5 \%)$ & 830,0 & 5,8 & 108 \\
Comédia e Romance & $39(2,8 \%)$ & 790,5 & 4,8 & 30,8 \\
Aventura & $30(2,2 \%)$ & 761,2 & 11,3 & 22,8 \\
Ação & $37(2,7 \%)$ & 687,8 & 11,1 & 25,4 \\
Comédia, Drama e & $6(0,4 \%)$ & 501,0 & 1,9 & 3,0 \\
Romance & $17(1,2 \%)$ & 433,0 & 2,4 & 7,4 \\
Ação e Suspense & $10(0,7 \%)$ & 222,2 & 1,3 & 2,2 \\
Romance & $5(0,4 \%)$ & 207,7 & 0,4 & 1,0 \\
Ação e Aventura & $12(0,9 \%)$ & 201,5 & 0,7 & 2,4 \\
Comédia e Ação & $446(32,6 \%)$ & 129,4 & 5,4 & 57,7 \\
Drama & $47(3,4 \%)$ & 125,4 & 1,4 & 5,9 \\
Comédia e Drama & $22(1,6 \%)$ & 123,0 & 0,6 & 2,7 \\
Animação & $43(3,1 \%)$ & 112,4 & 1,1 & 4,8 \\
Drama e Romance & $39(2,8 \%)$ & 59,2 & 0,9 & 2,3 \\
Suspense & $2(0,1 \%)$ & 23,8 & 0,05 & 0,05 \\
Ação e Terror & $14(1,0 \%)$ & 13,3 & 0,08 & 0,2 \\
Terror & $460(33,6 \%)$ & 10,5 & 0,2 & 4,8 \\
Documentário & 1.370 & 212,5 & 11,3 & 291 \\
\hline Total & & & & \\
\hline
\end{tabular}

Fonte: Ancine, IMDb. Elaboração própria.

Figura 10.1 - Valor captado com incentivo fiscal médio por ano (em milhões de reais de 2016)

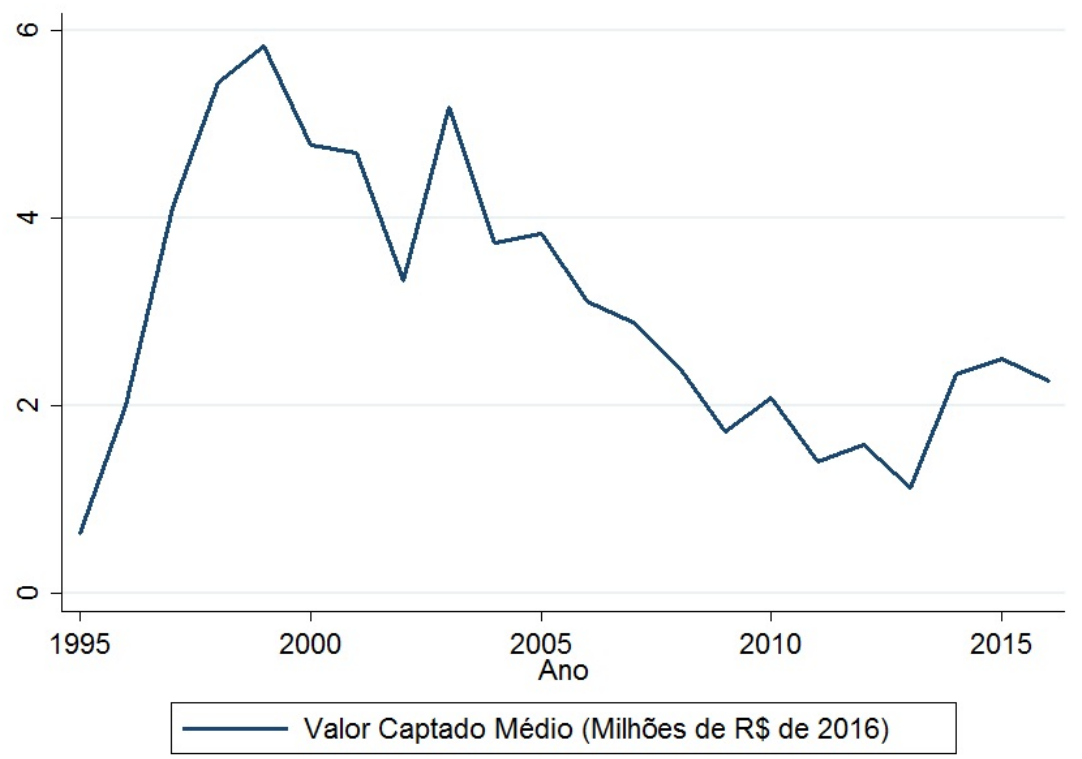

Fonte: Ancine. Elaboração própria. 
Tabela 10.6 - Estatísticas de público e de valor captado por quantidade de filmes produzidos pelo diretor

\begin{tabular}{ccccc}
\hline $\begin{array}{c}\text { Número de Filmes } \\
\text { do Diretor }\end{array}$ & $\begin{array}{c}\text { Total de } \\
\text { Diretores }\end{array}$ & $\begin{array}{c}\text { Total de } \\
\text { Filmes }\end{array}$ & $\begin{array}{c}\text { Média de } \\
\text { Público }\end{array}$ & $\begin{array}{c}\text { Média de } \\
\text { Valor Captado (R\$) }\end{array}$ \\
\hline 1 & 611 & 596 & 93.593 & 1.654 .703 \\
2 & 120 & 238 & 120.301 & 2.368 .952 \\
3 & 48 & 140 & 178.008 & 3.085 .862 \\
4 & 33 & 132 & 476.308 & 4.564 .637 \\
5 & 22 & 109 & 436.995 & 3.194 .316 \\
6 & 5 & 28 & 186.761 & 1.937 .157 \\
7 & 8 & 56 & 261.207 & 4.308 .676 \\
8 & 3 & 24 & 1.080 .725 & 3.769 .433 \\
9 & 3 & 27 & 936.871 & 5.028 .488 \\
10 & 2 & 20 & 11.281 & 568.493 \\
\hline Total & 855 & 1.370 & 212.521 & 2.564 .843 \\
\hline
\end{tabular}

Fonte: Ancine, IMDb. Elaboração própria.

Tabela 10.7 - Estatísticas de público e de valor captado por quantidade de filmes produzidos previamente pelo diretor

\begin{tabular}{cccc}
\hline $\begin{array}{c}\text { Experiência Prévia } \\
\text { do Diretor }\end{array}$ & $\begin{array}{c}\text { Total de } \\
\text { Filmes }\end{array}$ & $\begin{array}{c}\text { Média de } \\
\text { Público }\end{array}$ & $\begin{array}{c}\text { Média de } \\
\text { Valor Captado (R\$) }\end{array}$ \\
\hline 0 & 831 & 126.436 & 2.050 .840 \\
1 & 242 & 252.661 & 3.062 .047 \\
2 & 120 & 485.147 & 3.663 .283 \\
3 & 75 & 302.116 & 3.959 .178 \\
4 & 45 & 382.457 & 3.450 .074 \\
5 & 24 & 238.708 & 2.842 .034 \\
6 & 17 & 688.318 & 3.296 .018 \\
7 & 9 & 1.038 .285 & 3.319 .677 \\
8 & 5 & 14.320 & 1.622 .680 \\
9 & 2 & 47.90 & 100.412 \\
\hline Total & 1.370 & 212.521 & 2.564 .843 \\
\hline
\end{tabular}

Fonte: Ancine, IMDb. Elaboração própria. 


\section{Anexo C}

Anexo ao capítulo 6 de resultados.

Figura 11.1 - Lucro líquido e receita de incentivadoras estatais

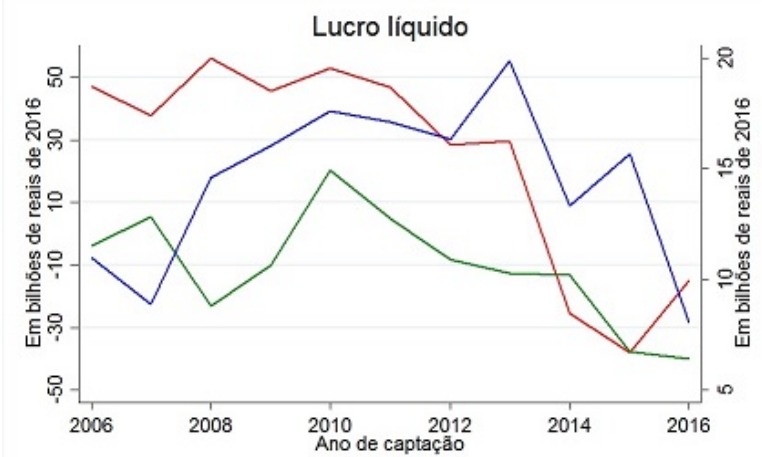

(a)

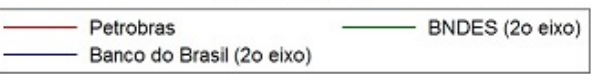

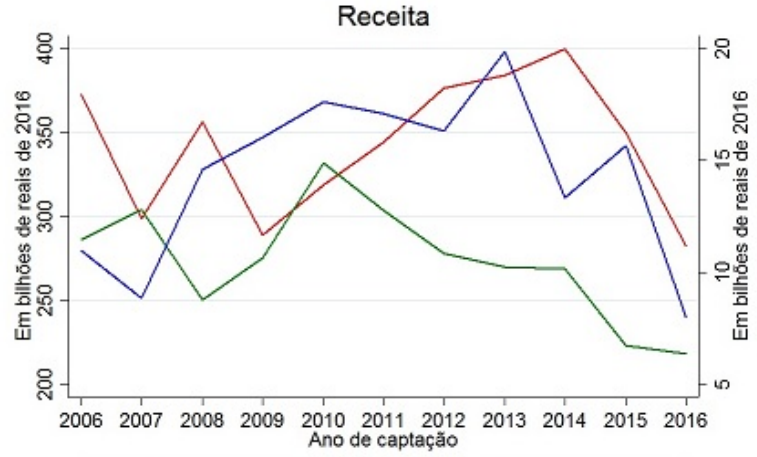

(b)

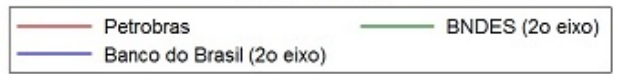

Fonte: Relacionamento com Investidores das empresas.

Tabela 11.1 - Estatísticas dos instrumentos

\begin{tabular}{lccc}
\hline Incentivador & Média & Desvio padrão & $\begin{array}{c}\text { Coeficiente de variação } \\
\text { (Desvio padrão/média) }\end{array}$ \\
\hline Petrobras $^{\dagger}$ & 0,5572 & 0,7265 & 1,3037 \\
BNDES $^{\dagger}$ & 0,1175 & 0,2025 & 1,7228 \\
Banco do Brasil $^{\dagger}$ & 0,0318 & 0,079 & 2,5047 \\
Caixa $^{\dagger}$ & 0,0125 & 0,0367 & 2,9290 \\
Sabesp $^{\dagger}$ & 0,0760 & 0,0921 & 1,2106 \\
Eletrobrás $^{\dagger}$ & 0,0160 & 0,0336 & 2,0954 \\
Outras estatais $^{\ddagger}$ & 0,4880 & 0,5605 & 1,1484 \\
Empresas privadas $^{\ddagger}$ & 3,9511 & 3,6676 & 0,9282 \\
Pessoas físicas & 0,0498 & 0,0779 & 1,5657 \\
\hline
\end{tabular}

Período de tempo: 2007-2016.

† Instrumentos construídos a partir do logaritmo natural da receita defasada.

$\ddagger$ Instrumentos construídos a partir do logaritmo natural dos rendimentos contemporâneos. 
Tabela 11.2 - Estimação de VI do modelo que explica a bilheteria de filmes nacionais Segundo estágio (demais mecanismos)

\begin{tabular}{lccc}
\hline Variável dependente: & $(1)$ & $(2)$ & $(3)$ \\
$\ln ($ Bilheteria $)$ & $\mathrm{MQO}$ & $\mathrm{MQO}$ & $\mathrm{MQ2E}$ \\
\hline $\ln ($ IncentivoFiscal $)$ & $0,144^{* * *}$ & $0,0770^{* * *}$ & $0,0508^{* *}$ \\
& $(0,0160)$ & $(0,0156)$ & $(0,0220)$ \\
$\ln ($ OutrasFontes $)$ & $0,0506^{* *}$ & $-0,00455$ & $-0,00151$ \\
& $(0,0200)$ & $(0,0196)$ & $(0,0220)$ \\
$\ln ($ InvestimentoF $S A)$ & $0,0982^{* * *}$ & $0,0331^{*}$ & 0,0248 \\
& $(0,0191)$ & $(0,0175)$ & $(0,0180)$ \\
Controles & $\mathrm{Não}$ & $\mathrm{Sim}$ & $\mathrm{Sim}$ \\
\hline Teste de restr. sobr. (p-valor) & - & - & 0,1240 \\
Teste de endogeneidade (p-valor) & - & - & 0,0392 \\
Observações & 514 & 514 & 425 \\
R-quadrado & 0,19 & 0,532 & 0,544 \\
\hline
\end{tabular}

Erros padrão robustos entre parênteses.

$* * * p<0,01,{ }^{* *} p<0,05,{ }^{*} p<0,1$.

Filmes exibidos entre 2007 e 2016.

Controles: gênero, ano, origem regional, produtora, diretor.

Tabela 11.3 - Estimação do modelo que explica a probabilidade de um filme nacional ser um documentário

\begin{tabular}{lcccc}
\hline $\begin{array}{l}\text { Variável dependente: } \\
\text { Documentario }\end{array}$ & $(1)$ & $(2)$ & $(3)$ & $(4)$ \\
\hline Ancine & $0,207^{* * *}$ & $0,289^{* *}$ & $0,318^{* * *}$ & $0,324^{* * *}$ \\
& $(0,0304)$ & $(0,114)$ & $(0,114)$ & $(0,113)$ \\
Valores incentivados & Sim & Sim & Sim & Sim \\
Dummies de ano & Não & Sim & Sim & Sim \\
Dummies de UF & Não & Não & Sim & Sim \\
Produtora & Não & Não & Não & Sim \\
Diretor & Não & Não & Não & Sim \\
\hline Observações & 1.266 & 1.266 & 1.266 & 1.266 \\
R-quadrado & 0,123 & 0,146 & 0,167 & 0,202 \\
\hline
\end{tabular}

Erros padrão robustos entre parênteses.

*** $p<0,01,{ }^{* *} p<0,05,{ }^{*} p<0,1$.

Totalidade dos documentários exibidos entre 1995 e 2016. 


\section{Anexo D}

Anexo ao capítulo 7 de robustez e extensões.

Tabela 12.1 - Regressões de diferenças-em-diferenças por categoria de origem

\begin{tabular}{lcc}
\hline Variável dependente: & $(1)$ & $(2)$ \\
& $\ln ($ Publico $)$ & Share_Publico \\
\hline A - Todas as origens & & \\
\hline Nacional*Ancine & 0.263 & $0.00417^{* * *}$ \\
& $(0.222)$ & $(0.000453)$ \\
\hline B - Por origem & & \\
\hline América Latina & 0,466 & 0,00168 \\
& $(0,614)$ & $(0,00105)$ \\
EUA/Canada & 0,18 & $0,00418^{* * *}$ \\
& $(0,224)$ & $(0,000446)$ \\
Europa Ociental & $-0,262$ & $0,00150^{*}$ \\
Restante da Europa & $(0,414)$ & $(0,000773)$ \\
Países Ibéricos & 0,372 & $3,59 \mathrm{E}-05$ \\
& $(0,702)$ & $(0,000393)$ \\
África & $-0,277$ & $-0,000141$ \\
& $(0,595)$ & $(0,000349)$ \\
Oriente Médio & $-0,891^{* *}$ & $-0,000199$ \\
Sudeste Asiático & $(0,451)$ & $(0,000211)$ \\
Oceania & $-0,566$ & $-2,39 \mathrm{E}-05$ \\
& $(0,507)$ & $(0,000350)$ \\
& $-0,122$ & 0,000798 \\
& $(0,659)$ & $(0,000945)$ \\
& $-2,350^{* * *}$ & $-0,00206^{* * *}$ \\
& $(0,614)$ & $(0,000725)$ \\
\hline
\end{tabular}

Erros padrão robustos entre parênteses. ${ }^{* * *} p<0,01,{ }^{* *} p<0,05,{ }^{*} p<0,1$.

Filmes exibidos entre 2001 e 2016. Observações com público abaixo do percentil de $90 \%$. 
Figura 12.1 - Distribuição dos parâmetros de tratamento estimados a partir da aleatorização das variáveis Nacional e Ancine - Observações abaixo dos percentis de $99 \%$ e de $90 \%$
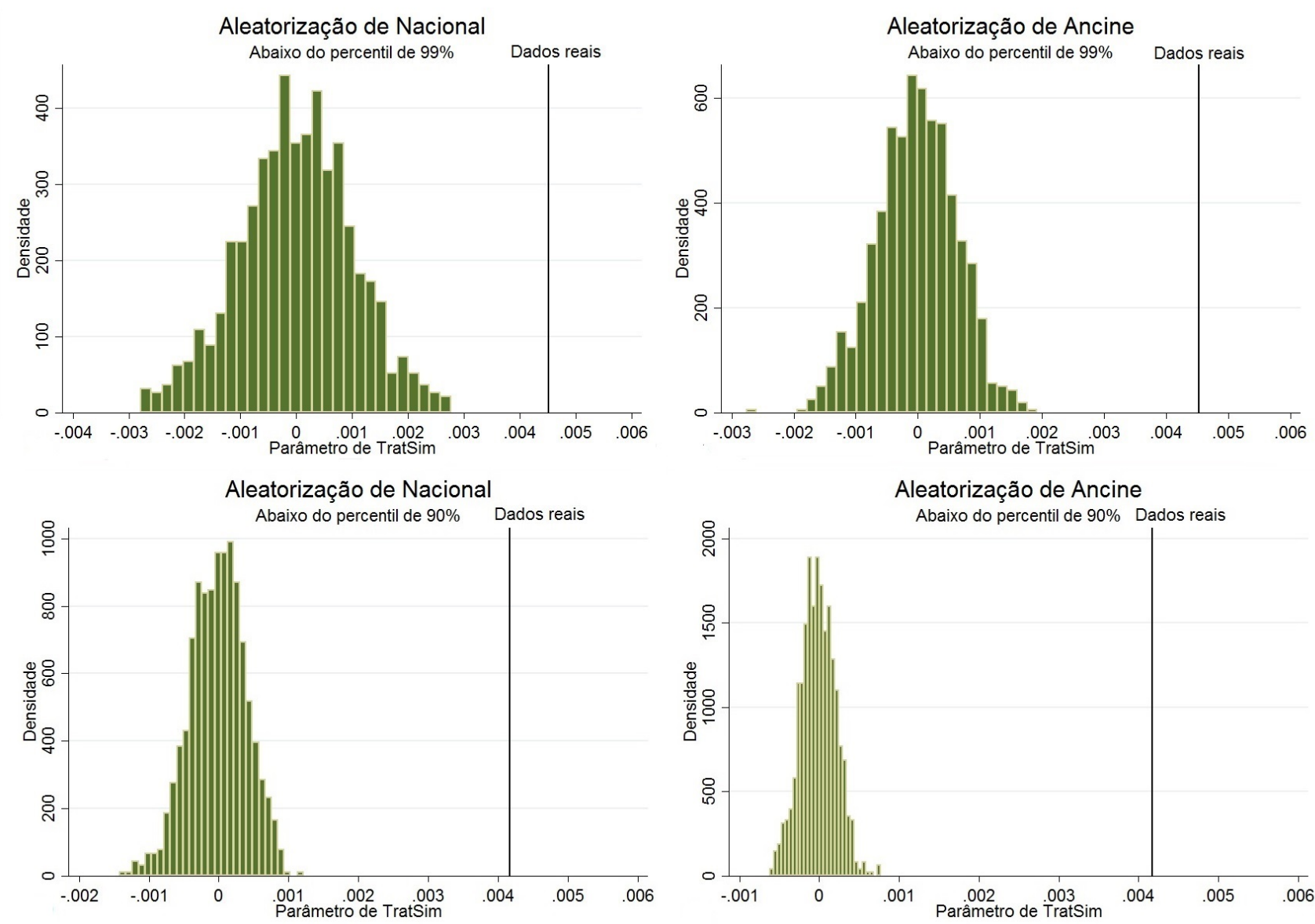

Tabela 12.2 - Estimação por propensity score-matching comparando a bilheteria de projetos incentivados com a de não incentivados

\begin{tabular}{lccc}
\hline Variável dependente: & $(1)$ & $(2)$ & $(3)$ \\
$\ln ($ Bilheteria $)$ & Documentário & Documentário e Drama & Todos os Gêneros \\
\hline Efeito de tratamento médio & 0.268 & $0.662^{* * *}$ & $0.745^{* * *}$ \\
& $(0.196)$ & $(0.195)$ & $(0.132)$ \\
Controles & Sim & Sim & Sim \\
\hline Observações & 397 & 894 & 1.236 \\
Captação positiva & $247(62 \%)$ & $635(71 \%)$ & $916(74 \%)$ \\
Sem captação & $150(38 \%)$ & $259(29 \%)$ & $320(26 \%)$ \\
\hline
\end{tabular}

Erros padrão robustos entre parênteses.

*** $p<0,01,{ }^{* *} p<0,05,{ }^{*} p<0,1$.

Filmes exibidos entre 1995 e 2016.

Controles: gênero/temática, ano, origem regional, produtora, diretor. 


\section{Apêndice A - Definições, siglas e abre- viações}

A subseção A.1 apresenta definições de termos recorrentemente utilizados ao longo do trabalho, seguindo a acepção com que foram empregados. Os significados a eles atribuídos são, portanto, de um modo geral, específicos ao presente contexto. Do mesmo modo, as formas extensivas de siglas e abreviações de aplicação frequente no trabalho seguem na subseção A.2.

\section{A.1 Definições}

Audiovisual: atividade voltada à gravação e posterior reprodução de conteúdos em áudio e vídeo.

Filme: entende-se um filme, neste trabalho, como uma obra cinematográfica de longa metragem destinada preferencialmente à exibição através da projeção em salas próprias a esse uso.

Cinema: referência ao conjunto de atividades que partem da produção de um filme e estendem-se até à sua exibição final.

Produção cinematográfica: envolve a elaboração do projeto do filme, a definição e construção do roteiro, a formação do elenco de atores principais, a constituição do conjunto de profissionais técnicos e artísticos, a obtenção de serviços de filmagem, o acesso a locações, a filmagem, a edição e a finalização do filme.

Distribuição cinematográfica: inicia com a compra dos direitos de comercialização do filme e abrange a sua divulgação e a sua concessão para diferentes formas de reprodução da obra.

Exibição cinematográfica: referência à principal forma de reprodução de um filme, que ocorre através da sua projeção em salas de cinema.

Complexo de cinema: conjunto de salas de exibição de cinema, sendo responsável pela principal forma de exibição comercial de um filme.

Produtora: empresa responsável pela produção cinematográfica.

Distribuidora: empresa responsável pela distribuição cinematográfica. 
Exibidora: empresa responsável pela exibição cinematográfica.

Diretor: lidera o conjunto de profissionais técnicos e artísticos, sendo, portanto, responsável pela articulação de seus trabalhos. Ao lado do elenco de atores principais, consiste no elemento envolvido em um filme de maior reconhecimento por parte do público.

Gênero: classificação temática de filmes que parte da motivação e do conteúdo básico do roteiro e que se associa a diferentes tipos de linguagem cinematográfica, em termos de atuação dos atores, condução da câmera, fotografia, trilha sonora, edição de som, etc. A partir das distintas combinações de gênero dispostas na base de dados da IMDb, definiram-se 18 categorias de gênero exploradas ao longo do trabalho: drama, drama e romance, comédia e drama, comédia, comédia e ação, comédia e aventura, comédia, drama e romance; comédia e romance, romance, aventura, ação e aventura, ação, ação e terror, ação e suspense, terror, suspense, animação e documentário.

Qualificativo de gênero: temática recorrente que, combinada às categorias de gênero definidas acima, implica nos gêneros dispostos pela IMDb para os filmes da sua base de dados. Encontram-se disponíveis as seguintes temáticas: guerra, história, fantasia, família, ficção científica, música, esporte e biografia.

Origem: definido a partir da região predominante envolvida na produção de um filme, considerando-se a origem do diretor e demais profissionais técnicos e artísticos, do elenco e da produtora. A partir das distintas combinações de origem dispostas na base de dados da IMDb, definiram-se 10 categorias de origem exploradas ao longo do trabalho: EUA ou Canadá, Brasil, Europa Ocidental, América Latina, Países Ibéricos, Restante da Europa, Sudeste Asiático, África, Oceania e Oriente Médio.

Origem regional: unidade da federação definida pela Ancine como de origem de um filme nacional.

Ano de exibição: ano em que majoritariamente o filme esteve à disposição do público em salas de exibição comerciais.

Ano de incentivo: ano de pedido de incentivo fiscal por um projeto de audiovisual, tal como registrado na base que relaciona todos os projetos proponentes e que foi disponibilizada pela Ancine. Na circunstância em que um projeto apresenta pedidos em mais de um ano, define-se como o ano de incentivo aquele correspondente ao primeiro pedido.

Período de produção: definido, a partir das bases de dados disponíveis, pela diferença entre o ano de exibição de um filme e o ano de seu primeiro pedido de incentivo fiscal. 
Compreende o período necessário para as atividades de produção cinematográfica.

Público: variável que agrega todas as pessoas que, em um dado ano, frequentaram uma sessão comercial de exibição de um filme em uma sala de cinema nacional, contemplando aquelas com pagamento integral do ingresso, meia-entrada e gratuidades.

Bilheteria: valor arrecadado como renda decorrente da exibição comercial de um filme, em um dado ano, considerando-se, portanto, apenas a parcela de público com pagamento integral do ingresso ou com meia-entrada.

Avaliação do público: média das notas atribuídas a um filme pelos usuários do website IMDb.

Fomento: atividade governamental de apoio financeiro a projetos de audiovisual, no presente contexto. Pode assumir as formas de incentivo fiscal, de investimento e de transferências de renda.

Incentivo fiscal: renúncia fiscal em que um incentivador tem abatimento em um imposto, uma vez comprovado um investimento, um patrocínio ou uma doação a um projeto de audiovisual, no presente contexto.

Lei do Audiovisual: lei federal 8.685 de 20 de julho de 1993, voltada ao incentivo fiscal à produção, à distribuição e à exibição de projetos de audiovisual. Os $\operatorname{artigos} 1^{o}, 1^{\circ} \mathrm{A}$, $3^{o}$ e $3^{\circ} \mathrm{A}$ instituem formas precisas de renúncia fiscal: o artigo $1^{o}$ prevê a dedução de Imposto de Renda em contrapartida ao investimento em projetos, enquanto que o artigo $1^{o} \mathrm{~A}$ se associa a patrocínios. Os artigos $3^{\circ}$ e $3^{\circ} \mathrm{A}$ implicam no abatimento de impostos devidos em decorrência da exploração, em território nacional, de conteúdo audiovisual estrangeiro.

Lei Rouanet: lei federal 8.313 de 23 de dezembro de 1991, cria uma série de mecanismos de incentivo a atividades culturais, destacando-se a renúncia fiscal prevista pelo artigo 18. Incentivador: agente econômico, pessoa jurídica ou física, privado ou estatal, cuja inversão (investimento, patrocínio ou doação) em um projeto de audiovisual implica na possibilidade de obtenção de uma correspondente dedução fiscal.

Investimento do FSA: compra de participação, pelo Fundo Setorial do Audiovisual, em projetos de audiovisual nacionais que se propõem a receber esses recursos a partir da inscrição em linhas de fomento específicas.

Outras fontes de captação: formas de fomento à exceção do incentivo fiscal representado pelos artigos pertinentes da Lei do Audiovisual e da Lei Rouanet e à exceção do 
investimento do FSA. Consistem, basicamente, em transferências de recursos tendo por base o Prêmio Adicional de Renda (PAR) e o Programa Ancine de Incentivo à Qualidade (PAQ).

Projeto: descrição das principais características de um projeto de produto audiovisual, compreendendo o título, a empresa proponente, o segmento de mercado (produção, distribuição ou exibição), o gênero, os responsáveis técnicos e artísticos, etc.

Regulação e fiscalização: disposição de regras para o funcionamento de um setor e averiguação de seu cumprimento por uma autoridade competente. Objetiva conduzir um setor de acordo com os princípios gerais da política pública.

Enforcement: condição pela qual as ações ótimas de agentes são condizentes com as regras estabelecidas pelos gestores da política pública.

Tratamento: intervenção realizada por meio de instrumentos de política pública, conduzida por seus gestores objetivando impactar uma variável de resultado.

Outcome: variável de resultado elencada como relevante a partir dos objetivos da política pública.

Variável de controle: variável explicativa utilizada para uma estimação mais precisa do efeito parcial de uma outra variável explicativa de interesse, em termos de consistência (aproximação assintótica ao parâmetro verdadeiro) e de menor variância do estimador. Uma vez que um controle apresente correlação com a variável de resultado e com a variável explicativa de interesse, a sua utilização explícita no modelo diminui o viés e a inconsistência dos estimadores. Ao mesmo tempo, conforme aumente a capacidade explicativa de um modelo, reduz a variância dos estimadores.

Elasticidade: a elasticidade de uma variável $y$ em termos de uma outra variável $x$ consiste na variação percentual em $y$ para uma variação de um ponto percentual em $x$.

Outlier: uma observação para uma dada variável é denominada um outlier se for suficientemente discrepante com relação à média das demais observações.

Erro padrão robusto: raiz quadrada da variância de um estimador calculada de forma robusta à heterocedasticidade e à autocorrelação dos termos de erro, isto é, permite-se um formato genérico para a matriz de variância/covariância dos termos de erro.

Variável instrumental: também definido como um instrumento, z é uma variável instrumental para $x$ na medida em que satisfaça duas hipóteses: i) hipótese de relevância: $\operatorname{Cov}(x, z) \neq 0$; ii) hipótese de exogeneidade: $\operatorname{Cov}(z, \epsilon)=0$, onde $\epsilon$ é o termo de erro 
do modelo de regressão linear que explica $y$ através das variações em $x$ e nas demais variáveis explicativas. Portanto, uma variável instrumental para uma dada variável explicativa deve covariar com essa de maneira exógena, isto é, sem apresentar correlação com os fatores não observáveis que afetam a variável de resultado.

\section{A.2 Siglas e abreviações}

Ancine: Agência Nacional do Cinema, criada pela Medida Provisória 2.228-1 de 06 de setembro de 2001. Consiste em uma agência reguladora vinculada ao extinto Ministério da Cultura, integrado, a partir de 2019, ao Ministério da Cidadania. Apresenta como atribuições a regulação, a fiscalização e a promoção do fomento, aplicando-se às atividades audiovisuais, notadamente o cinema.

OCA: Observatório Brasileiro do Cinema e do Audiovisual, criado em dezembro de 2008, tem por objetivo a concentração e a difusão de informações setoriais produzidas pela Ancine através de suas atividades de monitoramento.

Condecine: Contribuição para o Desenvolvimento da Indústria Cinematográfica Nacional, criada pela Medida Provisória 2.228-1/01, tendo por fatos geradores: a veiculação, a produção, o licenciamento e a distribuição de obras cinematográficas e videofonográficas com finalidade comercial. Atualmente destina-se a compor o Fundo Setorial do Audiovisual, financiando o incentivo ao setor através de investimentos realizados pelo fundo.

FSA: Fundo Setorial do Audiovisual, trata-se de uma particularização do Fundo Nacional da Cultura voltada às atividades audiovisuais, notadamente o cinema e a televisão. O fundo atua em consonância com a Ancine, operando programas de fomento criados, inclusive, pela mesma medida provisória que instituiu a agência.

Prodecine: Programa de Apoio ao Desenvolvimento do Cinema Brasileiro, criado pela MP 2.228-1/01 e operado pelo FSA, incentiva a produção e a distribuição de obras cinematográficas nacionais através de investimentos do fundo em projetos participantes de editais anuais.

Prodav: Programa de Apoio ao Desenvolvimento do Audiovisual Brasileiro, criado pela MP 2.228-1/01 e operado pelo FSA, incentiva, através de investimentos do fundo, projetos nacionais de produção e de distribuição de conteúdo televisivo.

PCPV: Programa Cinema Perto de Você, criado pela MP 2.228-1/01 e operado pelo 
FSA, incentiva projetos nacionais de exibição cinematográfica, principalmente aqueles relacionados ao mercado de salas de exibição.

PAR: Prêmio Adicional de Renda, criado pelo artigo 54 da MP 2.228-1/01 e instituído em 2006, consiste em um incentivo financeiro a obras cinematográficas nacionais inscritas em editais anuais e escolhidas pelo corpo técnico da Ancine.

PAQ: Programa Ancine de Incentivo à Qualidade, criado em 2006, premia obras cinematográficas nacionais vencedoras ou participantes de mostras competitivas de festivais que dispõem de juri oficial.

CVM: Comissão de Valores Mobiliários, autarquia vinculada ao Ministério da Fazenda e responsável pela regulação e pela fiscalização do mercado de ativos financeiros.

IMDb: Internet Movie Database, website que disponibiliza informações sobre filmes exibidos em todo o mundo. Proporcionou, dessa forma, características dos filmes exibidos no Brasil, como gênero, origem, produtora, diretor e avaliação do público usuário do website. MQO: Mínimos Quadrados Ordinários, técnica estatística para a estimação dos parâmetros de modelos de regressão lineares. Especialmente utilizada para a obtenção de estimativas dos efeitos parciais de variáveis explicativas sobre uma variável de resultado de interesse. MQ2E: Mínimos Quadrados em Dois Estágios, técnica variante dos MQO que explora as variações exógenas de uma variável explicativa $x$, isto é, variações desprovidas de correlação com o termo de erro do modelo de regressão linear para a variável de resultado de interesse, de a modo a prover, então, uma estimativa consistente para o efeito parcial de $x$. 


\section{Apêndice B - Distribuição e Exibição}

O objetivo deste apêndice consiste em complementar a exposição de dados apresentada nos capítulos 3 e 4, sendo que, pelo nível de desagregação das bases, foi possível uma descrição pormenorizada e uma posterior aplicação metodológica rigorosa de dados voltados aos resultados em termos de exibição e de público e bilheteria de filmes que foram exibidos no país entre 1995 e 2016.

Se tais exposições presentes no desenvolvimento do trabalho se relacionam aos filmes produzidos e exibidos, de modo que o segmento de atividade da produção pôde ter seus outcomes devidamente medidos, o mesmo não se aplica aos segmentos da distribuição e da exibição, para os quais as bases disponíveis não permitem uma adequada aplicação metodológica para a avaliação de impactos da política pública do setor.

Dessa forma, os dados apresentados neste apêndice têm uma finalidade expositiva, por conta da natureza agregativa das bases disponíveis. Entre 2009 e 2016, para a distribuição, e entre 2007 e 2015, para a exibição, os dados expostos abaixo retratam o panorama geral desses segmentos de atividade.

No período que se estende de 2009 a 2016, do total de público anual, em média $72 \%$ corresponde a filmes distribuídos por empresas internacionais, aplicando-se a proporção análoga de $73 \%$ para a renda de bilheteria. Ao mesmo tempo, em média $75 \%$ do total de filmes lançados anualmente se associa a distribuidoras nacionais. Distinguindo a origem dos filmes distribuídos entre nacional e internacional em média $90 \%$ dos filmes brasileiros lançados correspondem a distribuidoras nacionais, enquanto que o lançamento de produções internacionais tem participação média menor de empresas domésticas, $68 \%$.

Em resumo, as distribuidoras brasileiras lançam grande parte das obras exibidas no país, porém, concentram uma parcela inversamente proporcional do total de público e de bilheteria. Além disso, as produções nacionais dependem grandemente das distribuidoras nacionais.

A tabela 14.1 abaixo indica a distribuição das médias de lançamentos por tipo de distribuidora (internacional ou nacional) e por número de salas na estreia do filme no Brasil. Percebe-se uma distribuição equilibrada por parte de distribuidoras internacionais, em que a maioria dos lançamentos ocorre entre 100 e 300 salas no momento de estreia. 
As distribuidoras nacionais, no entanto, contam, para os seus lançamentos, com até 10 salas na estreia para, em média, 48\% dos filmes lançados anualmente. Para produções de grande escala, novamente há notável discrepância entre distribuidoras internacionais e nacionais: em média, 14\% dos lançamentos de distribuidoras internacionais estreiam em mais de 700 salas, enquanto que a proporção aplicável a lançamentos de distribuidoras nacionais corresponde a apenas $1 \%$.

Em resumo, os lançamentos de distribuidoras nacionais contam, em média, com poucas salas no momento da estreia, ao contrário das distribuidoras internacionais, que tendem a lançar filmes em um grande número de salas simultaneamente na estreia.

Tabela 14.1 - Médias anuais de lançamentos por tipo de distribuidora e por número de salas (2009-2016)

\begin{tabular}{lcccc}
\hline & \multicolumn{2}{c}{ Internacional } & \multicolumn{2}{c}{ Nacional } \\
\hline Número de salas na estreia & Média & Proporção & Média & Proporção \\
\hline Até 10 salas & 4 & $5 \%$ & 134 & $48 \%$ \\
Mais de 10 até 100 salas & 21 & $23 \%$ & 98 & $35 \%$ \\
Mais de 100 até 300 salas & 30 & $33 \%$ & 30 & $11 \%$ \\
Mais de 300 até 700 salas & 22 & $25 \%$ & 13 & $4 \%$ \\
Mais de 700 salas & 13 & $14 \%$ & 3 & $1 \%$ \\
Não informado & 0 & $0 \%$ & 2 & $1 \%$ \\
\hline Total & 91 & $100 \%$ & 280 & $100 \%$ \\
\hline
\end{tabular}

Fonte: Ancine.

Com relação às principais distribuidoras, as cinco maiores acumulam, entre 2009 e 2016, um terço do total lançado (33\%), sendo a maior brasileira (Vitrine Filmes) correspondente a $3 \%$ do total (décima primeira na classificação de maiores lançamentos). O segmento de distribuição conduzida por empresas estrangeiras, embora seja responsável por $25 \%$, em média, do total lançado anualmente, é bastante concentrado, havendo um número expressivo de pequenas distribuidoras nacionais, que implicam em uma proporção média anual de $75 \%$.

O parque exibidor no país tem sua evolução resumida pela figura 14.1 abaixo. Após uma redução de mais de $50 \%$ no número de salas de exibição no país, entre as décadas de 1970 e de 1990, ao longo dos anos 2000 tem ocorrido uma forte expansão do parque exibidor. De um mínimo de 1.033 salas em 1995, o crescimento tem sido quase ininterrupto, alcançando mais de 3.000 salas em 2015, patamar verificado ao fim da década de 
1970. Portanto, ocorreu uma recuperação, no pós-Ancine, do número de salas de exibição no país.

Figura 14.1 - Salas de exibição por ano

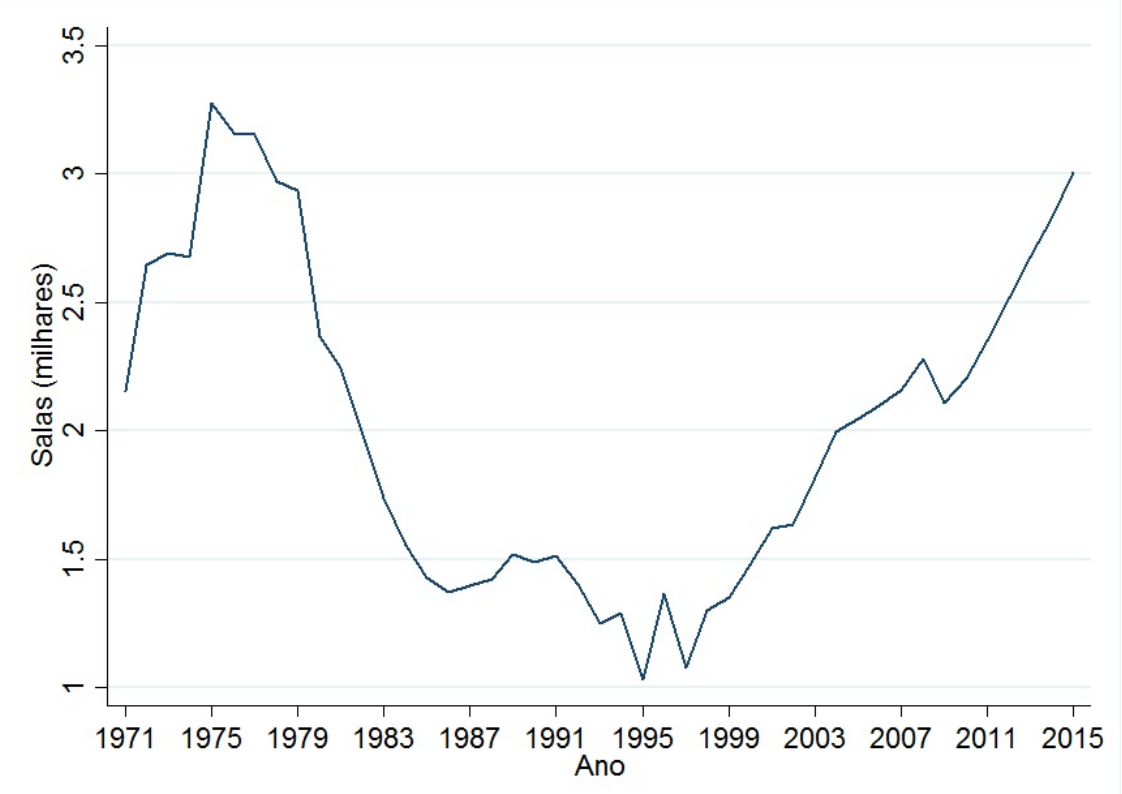

Fonte: Ancine. Elaboração própria.

A tabela|14.2 abaixo apresenta as médias dos números de salas de exibição por região do Brasil no intervalo 2007-2015. Então, observa-se que, anualmente, 57\% das salas de exibição, em média, localizam-se na região Sudeste, enquanto que apenas $5 \%$ se localiza no Norte do país. Considerando os estados individualmente, em média, 34\% das salas de exibição de cada ano correspondem ao estado de São Paulo e $12 \%$ se associa ao estado do Rio de Janeiro. No outro extremo, o estado do Acre tem uma participação média no total anual de salas equivalente a apenas $0,15 \%$, sendo que seu máximo foi alcançado em 2011 e consiste no número de 7 salas de exibição.

Em resumo, há notável concentração do parque exibidor na região Sudeste do país, sobretudo no estado de São Paulo. Os estados do Centro-Oeste e, sobretudo, do Norte dispõem de uma quantidade de salas consideravelmente pequena.

As informações do número de salas por UF e por região se associam a uma desigual distribuição do parque exibidor quando considerada a faixa populacional dos municípios. Como demonstra a tabela 14.3 , em média, apenas 1,8\% dos municípios com até 50 mil habitantes dispõem de cinema. Além disso, em média, 59\% das salas de exibição se encontram em municípios com mais de 500 mil habitantes e quase 90\% corresponde a cidades 
Tabela 14.2 - Médias anuais do número de salas de exibição por região do Brasil (20072015)

\begin{tabular}{lcc}
\hline Região & Salas & Proporção \\
\hline Norte & 115 & $4,6 \%$ \\
Nordeste & 314 & $12.6 \%$ \\
Centro-Oeste & 220 & $9 \%$ \\
Sudeste & 1.408 & $57,4 \%$ \\
Sul & 403 & $16,4 \%$ \\
\hline Total & 420 & $100 \%$ \\
\hline
\end{tabular}

Fonte: Ancine.

de porte médio ou grande (mais de 100 mil habitantes).

Em resumo, o parque exibidor se encontra majoritariamente em grandes municípios, sendo que a expansão considerável do número de salas de exibição (figura 14.1), nos últimos anos, não se voltou às cidades que até então não apresentavam um amplo acesso ao consumo de cinema.

Tabela 14.3 - Médias anuais da proporção de municípios com cinema e da proporção do total de salas

\begin{tabular}{lcc}
\hline Faixa populacional & $\begin{array}{c}\text { Proporção dos } \\
\text { municípios com cinema }\end{array}$ & Proporção das salas \\
\hline Até 50 mil habitantes & $1,8 \%$ & $3,9 \%$ \\
De $\mathbf{5 0}$ a $\mathbf{1 0 0}$ mil habitantes & $30,8 \%$ & $6,1 \%$ \\
De $\mathbf{1 0 0}$ a 500 mil habitantes & $68,2 \%$ & $30,7 \%$ \\
Mais de 500 mil habitantes & $99,2 \%$ & $59,3 \%$ \\
\hline Total & $7,0 \%$ & $100,0 \%$ \\
\hline
\end{tabular}

Fonte: Ancine.

As principais conclusões do acima exposto apontam para que as distribuidoras nacionais concentrem grande número de lançamentos e, ao mesmo tempo, pequenos valores de público e de bilheteria. Além disso, as distribuidoras nacionais contam com poucas salas para a estreia de seus lançamentos. Por fim, mesmo com expressivo crescimento recente no número de salas de exibição no país, ainda é destacada a concentração do parque exibidor no Sudeste e em municípios de grande porte. 


\section{Apêndice C - Índice de Convencionalidade}

O cálculo do índice de convencionalidade buscou quantificar os atributos de um filme que o favorece a ser prontamente absorvido pelo público consumidor. Assim, foram atribuídas pontuações a cada categoria das seguintes características de filmes: gênero, origem, influência dos EUA, grande produtora/distribuidora associada e diretor vencedor de Oscar.

Para cada uma dessas características, foram realizadas regressões do público contra dummies das suas diferentes categorias. Na sequência, os parâmetros das categorias foram ordenados de forma decrescente, sendo a elas atribuídos números de $K_{c}$, para a categoria de maior parâmetro, a 1, para a categoria de menor parâmetro, onde $K_{c}$ é o número de categorias disponíveis para a característica $c$. Para o gênero, $K_{\text {genero }}=18$, correspondendo às 18 categorias de gênero apresentadas na seção 4. Para a origem, $K_{\text {origem }}=10$, correspondendo às 10 categorias de origem apresentadas na seção 4 . Para produtora/distribuidora, $K_{\text {prod }}=9$, correspondendo às seguintes empresas: Marvel, Globo Filme, DreamWorks, Walt Disney, Columbia Pictures, Warner, Fox, Universal e demais produtoras. Para Oscar, $K_{\text {Oscar }}=4$, correspondendo a vencedor de Oscar pós1990, pós-1960, pós-1920 e não vencedor de Oscar. Para a influência dos EUA, $K_{E U A}$, apenas distinguiu-se entre EUA compondo ou não lista de países produtores, tal como disponibilizado pela IMDb. Uma vez ordenadas as categorias de cada característica e tendo sido a elas atribuídos números de $K_{c}$ até 1 , tais pontuações foram padronizadas de modo a variar entre 0 e 10.

Os pesos de cada uma das características no cômputo do índice decorreram da ordenação decrescente dos seus efeitos sobre o $R^{2}$ das suas inclusões na regressão que explica o público de cada filme. Agora, dessa ordenação, foram calculados pesos cuja soma corresponde à unidade. O índice de convencionalidade para cada filme é obtido, então, da multiplicação das notas de cada característica pelo seu peso e da subsequente soma de cada nota ponderada. Por fim, os valores do índice foram normalizados de forma a variar entre 0 e 1. A tabela 15.1 abaixo apresenta a pontuação de cada categoria e o peso de cada característica para o cálculo do índice de convencionalidade. 
Tabela 15.1 - Pontuação do índice de convencionalidade

\begin{tabular}{|c|c|c|c|}
\hline Categoria & Pontuação & Categoria & Pontuação \\
\hline \multicolumn{2}{|l|}{ Gênero $($ Peso $=0,2667)$} & \multicolumn{2}{|c|}{ Origem $($ Peso $=0,2)$} \\
\hline Ação e Aventura & 10,00 & EUA/Canada & 10,00 \\
\hline Aventura & 9,44 & Brasil & 9,00 \\
\hline Animacao & 8,89 & Europa Ocidental & 8,00 \\
\hline Comédia e Aventura & 8,33 & Oceania & 7,00 \\
\hline Ação e Terror & 7,78 & Sudeste Asiático & 6,00 \\
\hline Acao & 7,22 & Países Ibéricos & 5,00 \\
\hline Comédia & 6,67 & Africa & 4,00 \\
\hline Comédia e Romance & 6,11 & $\mathrm{AL}$ & 3,00 \\
\hline Ação e Suspense & 5,56 & Restante da Europa & 2,00 \\
\hline Terror & 5,00 & Oriente Médio & 1,00 \\
\hline Comédia e Acao & 4,44 & \multicolumn{2}{|c|}{ EUA $($ Peso $=0,1333)$} \\
\hline Suspense & 3,89 & Com EUA & 1,00 \\
\hline Romance & 3,33 & Sem EUA & 0,00 \\
\hline Comedia, Drama e Romance & 2,78 & \multicolumn{2}{|c|}{ Produtora/Distribuidora $($ Peso $=0,3333)$} \\
\hline Drama e Romance & 2,22 & Marvel & 10,00 \\
\hline Drama & 1,67 & Globo Filmes & 8,89 \\
\hline Comédia e Drama & 1,11 & DreamWorks & 7,78 \\
\hline Documentário & 0,56 & WaltDisney & 6,67 \\
\hline Diretor vencedor de Oscar (Pes & $\mathrm{o}=0,0667)$ & Columbia Pictures & 5,56 \\
\hline Com vencedor de Oscar (pós-1990) & 10 & Warner & 4,44 \\
\hline Com vencedor de Oscar (pós-1960) & 5 & Fox & 3,33 \\
\hline Com vencedor de Oscar (pós-1920) & 0 & Universal & 2,22 \\
\hline Sem vencedor de Oscar & 0 & Demais produtoras & 1,11 \\
\hline
\end{tabular}

As pontuações seguem da ordenação decrescente dos públicos médios por categoria e os pesos da ordenação decrescente do efeito dos parâmetros sobre o $R^{2}$ do modelo que explica o público. 